\author{
Universidade de São Paulo \\ Faculdade de Filosofia, Letras e Ciências Humanas \\ Departamento de Letras Modernas \\ Programa de Pós-Graduação em Língua e Literatura Francesa

\section{Leitura em Francês na Internet: projetos interdisciplinares no Ensino Médio}

Lucia Campos de Oliveira Zucchi

Dissertação apresentada ao Programa de Pós-Graduação em Língua e Literatura Francesa, do Departamento de Letras Modernas da Faculdade de Filosofia, Letras e Ciências Humanas da Universidade de São Paulo, para obtenção do título de Mestre em Letras.

Orientadora: Profa. Dra. Maria Sabina Kundman São Paulo

Novembro de 2008 


\section{AGRADECIMENTOS}

A minha cara orientadora Profa. Dra. Maria Sabina Kundman, sem a qual nada, mas nada mesmo, teria acontecido. Que Deus a abençoe.

A minhas examinadoras de qualificação, Profa. Dra. Cristina M.Casadei Pietraróia e Profa. Dra. Vera Lucia Marinelli, pelas preciosas orientações.

Ao Colégio São Mauro, causa e finalidade de meus estudos em pós-graduação. 


\title{
RESUMO
}

A leitura é uma atividade complexa, de grande importância no ensino/ aprendizagem de uma língua estrangeira, sendo considerada como um elemento a ser priorizado no sistema educacional brasileiro de nível médio, no ensino do francês, segundo os PCNs, em função de sua utilidade e facilidade de acesso. Ela é também a atividade por excelência do usuário da Internet. $\mathrm{O}$ presente trabalho propõe uma reflexão sobre as contribuições que a prática da leitura, associada ao uso da Internet e a projetos interdisciplinares pode trazer para $\mathrm{o}$ aprendizado do francês, língua estrangeira, em contexto institucional. A experiência que possibilitou nosso estudo foi realizada em classes do primeiro ano do ensino médio num estabelecimento de ensino particular da cidade de São Paulo, onde o francês faz parte da grade curricular. A prática da leitura, num momento em que se valoriza o ensino por competências segundo o Quadro Europeu de Referência para as Línguas, foi realizada com estudo de textos de divulgação científica, nas áreas de História/Geografia e Física, com a metodologia de projetos de aprendizagem interdisciplinares visando a obtenção de autonomia de leitura em aprendizes de nível iniciante/intermediário.

Palavras-chave: leitura em LE, Internet, pedagogia de projetos, interdisciplinaridade, TICE

\begin{abstract}
Reading is a complex activity which plays a key role in a foreign language teaching and learning. This ability is considered an element to be prioritized in Brazilian high school educational system concerning French language teaching, according to the National Standard Curriculum, due to its usefulness and easy access. Reading is also the activity per excellence of Internet users. The present work proposes a discussion over the contributions that the reading practice, associated with Internet use and interdisciplinary projects may bring to French language teaching, foreign language teaching, in the institutional context. The experiment that enabled our study took place in high school first grades at a private school in São Paulo City, where French language is part of the school curriculum. Reading practice, at a moment in which the teaching per competences is highly valued according to the European Reference Chart to Languages, happened with the study scientific broadcasting texts in the fields of History, Geography and Physics, with the methodology of learning projects, aiming at the achievement of reading autonomy to beginners and intermediate learners.
\end{abstract}

\section{RÉSUMÉ}

La lecture est une activité complexe, de grande importance dans l'enseignement/apprentissage d'une langue étrangère et que l'on considère - selon les PCN - comme élément prioritaire dans le système éducatif brésilien pour l'enseignement du français au lycée, du fait de son utilité et de sa facilité d'accès. C'est aussi l'activité par excellence des internautes .Cette recherche est une réflexion sur les contributions que la pratique de la lecture, associée à l'utilisation d'internet et à des projets interdisciplinaires, peut apporter à l'apprentissage du français, langue étrangère, dans un contexte institutionnel. L'expérience qui a permis de réaliser notre étude a eu lieu dans des classes de seconde (première année de lycée) d'un établissement d'enseignement privé de la ville de São Paulo où le français fait partie du cursus obligatoire. La pratique de la lecture, à une époque où l'on valorise l'enseignement par compétences selon le Cadre Européen Commun de Référence pour les Langues, s'est appuyée sur l'étude de textes de divulgation scientifique, en Histoire/Géographie et Physique, en appliquant la méthodologie de projets d'apprentissage interdisciplinaires dont la finalité est l'autonomie en lecture des apprenants de niveau débutant/intermédiaire. 
LEITURA EM FRANCÊS NA INTERNET: PROJETOS INTERDISCIPLINARES

NO ENSINO MÉDIO

RESUMO 3

INDICE 4

INTRODUÇÃO 8

CAPÍTULO I - NATUREZA DA LEITURA EM FLE 14

1. Objetivo da leitura: a compreensão 14

2. Modelos de Compreensão em Leitura 16

3. Ler em LE: especificidades no acesso ao sentido 19

4. Abordando a leitura em FLE 27

Conclusão do Capítulo I 35

CAPÍTULO II - A INTERNET 37

1. Por que Internet? 37

2. O que é Internet? 39

3. O uso pedagógico da Internet (ou TICE) 45

Conclusão do Capítulo II 50

CAPÍTULO III - LEITURA EM INTERNET 51

1. O objeto da leitura 51

a. O suporte: o texto informatizado 51

b. A grande biblioteca : Internet 53

c. Hipertexto, o texto da Internet 56

2. Leitor: o internauta 62

3. Leituras 65

a. A Internet determina a leitura? 65 
b. A Abordagem Global do hipertexto 66

c. A diversificação das leituras 68

Conclusão do Capítulo III 73

CAPÍTULO IV - A METODOLOGIA DE LEITURA EM FLE NA INTERNET 74

1. A leitura como objetivo pedagógico em FLE 74

2. A escolha dos textos 77

3. As características da leitura 86

4. Os projetos pedagógicos 86

5. O treinamento 93

6. A avaliação 97

7. A autonomia 98

8. A interdisciplinaridade 100

Conclusão do Capítulo IV 101

\section{CAPÍTULO V - PROJETOS INTERDISCIPLINARES DE LEITURA EM FLE}

NA INTERNET PARA O ENSINO MÉDIO 104

1. Metodologia da pesquisa 105

2. Histórico dos projetos 108

a. Inserção no projeto pedagógico do Colégio 108

b. Os projetos anteriores 114

b.1. Russie 115

b.2. Astronomie 116

b.3. Apostila de Astronomia 122

b.4. Guerra dos Cem Anos 125

b.5. Tratados e Grupos em Política Internacional 126

3. O projeto Histoire de la Technologie Maritime 127 
a. Planejamento e organização

a.1. Escolha do tema 128

a.2. Descrição do grupo classe 128

a.3. Testagens preliminares 129

a.4. Investigação dos hábitos de leitura 130

a.5. Ensino da metodologia de pesquisa: Guia de pesquisa em FLE na Internet 131

a.6. Divisão em duplas 131

a.7. Detalhamento do tema 136

b.. Execução e apresentação 137

b.1. Pesquisa na Internet e confecção da apresentação em Power Point 137

b.2. Apresentação do Projeto durante a II FeClio 138

c. Atividades de avaliação 140

d. A "retomada" 141

4. Discussão e avaliação dos projetos 142

a. Análise da produção dos alunos 142

b. Avaliação do projeto 157

Conclusão do Capítulo V 158

CONCLUSÃO GERAL 158

BIBLIOGRAFIA 160

ANEXOS 191

Anexo 1 - Lista de sites propostos para a pesquisa 191

Anexo 2 - Entrevista com os alunos 192

Anexo 3 - Transcrição da leitura em voz alta 201

Anexo 4 - Entrevista com a Diretora do Colégio 211

Anexo 5 - Entrevista com a professora de História 216

Anexo 6 - Entrevista com o professor de Informática 219 
Anexo 7- Leitura e Línguas Estrangeiras no Projeto Pedagógico do Colégio

Anexo 8 - Teste de nível de conhecimento prévio em Francês

Anexo 9 - Atividade de leitura proposta por Custers, Pâquier e Rodier (2005 : 57)_225

Anexo 10 - Questionário Leitura em Internet e aprendizagem de FLE 226

Anexo 11 - Tabulação completa do Questionário 228

Anexo 12 - Questionário de Avaliação do Projeto Technologie, exemplar preenchido por Karysa 231

Anexo 13 - Tabulação do Questionário de Avaliação do Projeto Technologie 233

Anexo 14 - Texto das apresentações em Power Point do projeto Histoire de la

Technologie Maritime, comparado com textos de origem na Internet 236

\section{ANEXOS DIGITAIS}

(Esses arquivos encontram-se no CD anexo).

Projeto Histoire de la technologie maritime

Projeto-relâmpago

Guia de Pesquisa em Francês na Internet

Projeto Astronomie

Texto da dissertação 


\section{Introdução}

\section{Para o mestrado - Um pedido}

A idéia desse trabalho surgiu em 2003, quando comuniquei a M. Ivone P.M. Fedeli, diretora de meu colégio, a intenção de ingressar em um programa de mestrado, na FFLCH USP, na área de ensino/aprendizagem do Francês. Sua resposta foi: "Sugiro que faça um trabalho envolvendo Internet". De fato, a demanda social pelo uso da Internet na Educação já não permitia ignorar essa nova ferramenta, houvesse ou não um projeto pedagógico organizando seu emprego.

Na FFLCH USP, encontrei o vasto saber e a direção constante e suave de M.Sabina Kundman, que foram me conduzindo entre os escolhos novos e antigos da pedagogia do Francês Língua Estrangeira.

\section{Internet}

Dediquei-me então a estudar a Internet, desde os detalhes simples da operação e da pesquisa, até sua história e filosofia ${ }^{1}$, entrando nesse "mar de textos", da poética descrição de Machado $(2001)^{2}$. Li também os autores da pedagogia TICE, sobretudo em FLE, cujas obras fundamentais, aliás, já estavam escritas nessa época ${ }^{3}$, além de outros autores mais recentes ${ }^{4} \ldots$

Procurei conhecer a relação que tinham meus alunos com a Internet, através de uma pesquisa sobre a conexão e o uso de Internet ${ }^{5}$. Expus também a eles meus planos a

\footnotetext{
${ }^{1}$ LEVY, WOLTON, VIRILIO, ECO, SERRES

2 "o processo de leitura [...] é designado pela metáfora bastante pertinente da navegação, pois se trata realmente de 'navegar' ao longo de um imenso mar de textos que se superpõe e tangenciam”.

${ }^{3}$ LANCIEN, TARDIF, TOMÉ, MANGENOT e também ROUET, PERRENOUD, VANDENDORPE, RHÉAUME.

${ }^{4}$ LEGROS, DEMAIZIERE,

${ }^{5}$ Pesquisa realizada no colégio em 2004 e 2008.
} 
respeito, recebendo apoio, mas também olhares céticos, sorrisos de superioridade e mesmo a réplica de dois alunos dos mais hábeis e aficionados do colégio: "Mas, professora, não se aprende nada de útil na Internet!”

A primeira idéia que tive foi a criação de um site com material de leitura, jogos e atividades em francês. Não cheguei a esboçar um procedimento, entretanto, que valesse o trabalho que eu teria em montá-lo. Como primeira experiência prática, adotei a webquest, ferramenta criada por Dodge $^{6}$ para confecção de projetos em Internet. Empreguei duas vezes esse procedimento, com resultados satisfatórios, mas sem obter uma adesão entusiástica dos alunos. De fato, esse tipo de trabalho demanda um empenho maior que o habitual de sala de aula, sem dar ao aluno um objetivo exterior à própria metodologia, produzindo nele uma sensação de esforço inútil.

\section{Leitura}

Considero a leitura ${ }^{7}$ a melhor porta de entrada para a língua estrangeira, a mais acessível e mais produtiva, embora reconheça que a fala deva ser visada como o produto mais acabado dessa competência.

A leitura de textos autênticos sempre teve papel de destaque em minhas aulas. Ao lado de um método "generalista", eu leio com os alunos de $2^{\circ}$. ao $5^{\circ}$. ano do Ensino Fundamental um livro por bimestre, entre pequenas biografias, receitas culinárias e livros infantis de divulgação científica. Com base nessa experiência, considero que esse último gênero bastante apropriado para o ensino de leitura em LE, graças a características como clareza, preocupação didática, uso de vocabulário denotativo, formas verbais restritas ${ }^{8}$. Para turmas de $6^{\circ}$. ao $9^{\circ}$. ano do Ensino Fundamental, eu

\footnotetext{
${ }^{6}$ DODGE, B.

${ }^{7}$ Minhas justificativas estarão expostas no decorrer do trabalho!

${ }^{8}$ vide p. 83 citação de GOTI.
} 
utilizava textos de imprensa: para o $6^{\circ}$. e $7^{\circ}$. anos, revistas Okapi e Mikado e para o $8^{\circ}$. e $9^{\circ}$. anos, textos de revistas semanais como L'Express, Le Nouvel Observateur e jornais como Le Monde e Libération ${ }^{9}$. Ao chegar ao Ensino Médio, os bons alunos podiam ler sozinhos muitos textos desses periódicos.

Com o advento da Internet, a procura de textos ficou muito facilitada. Inicialmente eu imprimia os textos encontrados, fazia cópias e mantinha o procedimento costumeiro nas aulas: leitura em voz alta, explicação do vocabulário e questionário de interpretação de textos. Posteriormente, conforme as condições de horário da sala de informática do colégio, passei a utilizar a leitura em tela. O desconforto com essa forma de leitura, tão comum em adultos, não foi confirmada na pesquisa que realizei sobre os hábitos de leitura e conexão com Internet entre os alunos ${ }^{10}$.

Dentro da habilidade de leitura, meu objetivo é levar os alunos a atingir um limiar de leitura com compreensão, que os leve a ter auto-confiança para ler em autonomia, permitindo um uso do francês posterior ao Ensino Médio. A leitura é, segundo Eco (1996 : 2), a atividade principal do usuário da Internet. Como aproveitar o potencial da "grande biblioteca universal" em uma metodologia motivante, eficaz para o aprendizado de Francês, prática na sua implantação e bem encaixada nas rotinas do colégio, de forma a poder ser usada com freqüência?

\section{A busca metodológica}

A metodologia dos projetos de aprendizagem ${ }^{11}$ preconiza que o estudo centrado na resolução de um problema concreto, imediato e voltado para a comunidade escolar, é uma necessidade em termos de motivação e mesmo de aprendizado efetivo. Outros

\footnotetext{
${ }^{9}$ Atualmente eu adoto o método Édito, de HEU e MABILAT (2006) que propõe a leitura de textos de imprensa, para turmas a partir do $9^{\circ}$. ano.

${ }^{10}$ Pesquisa relatada na p. 129

${ }^{11}$ Cuja origem remonta a John DEWEY, mas que renasce com toda a força juntamente com a pedagogia TICE, em autores como PERRENOUD(1999)...
} 
autores, como Tardif (2002 : 24), propõe uma alternância de situações de desequilíbrio cognitivo - como são os projetos - com outras de reorganização e descontextualização das aprendizagens.

Sem fazer dos projetos um recurso exclusivo, constatei que eles propiciam ocasiões de intenso envolvimento dos alunos e de um empenho raramente apresentado em outras ocasiões. Do ponto de vista da implantação, eles se coadunaram perfeitamente com a política da escola, adequando-se sobretudo aos eventos que concluem os dois primeiros bimestres do ano escolar, a Feira de História e a Feira de Ciências.

A interdisciplinaridade é um conceito amplo da Filosofia da Ciência, que combate a excessiva compartimentalização do saber $^{12}$. No meu caso específico, ela serviu para mostrar a meu aluno que, através do Francês, ele pode chegar a muitos outros campos do conhecimento. Em termos de política escolar, ela associa o Francês com matérias mais prestigiadas e de maior peso curricular, como Física e História!

\section{A escolha da turma}

A escolha do $1^{\circ}$. ano do Ensino Médio para o desenvolvimento e aplicação dos projetos em estudo prendeu-se ao fato de que o nível de conhecimento de Francês da média dos alunos dessa série lhes permite ler textos simples com uma certa autonomia. Isso se dava, pelo menos, nas primeiras turmas em que eu apliquei essa metodologia. Da turma do $1^{\circ}$. Médio de 2008, é difícil dizer que tivesse um bom nível de leitura, como demonstram as testagens feitas antes e durante o projeto. Tal deficiência, entretanto, não impediu o desenvolvimento do trabalho e o progresso obtido foi, parece-me, bastante significativo.

\footnotetext{
${ }^{12}$ Esse conceito está exposto em MORIN (1994).
} 
Outro fator que me levou a trabalhar com o Ensino Médio, igualmente, é que a extensão dos conhecimentos de mundo e o domínio da linguagem tornam mais fáceis a independência em relação ao professor e a colaboração que caracterizam os projetos. Isso não significa que não seja possível aplicar essa metodologia a outros níveis escolares, com um cuidado maior na seleção de textos acessíveis a alunos mais jovens e acompanhamento mais intenso do trabalho por parte do professor.

\section{Os Projetos Interdisciplinares de Leitura em Francês na Internet para o Ensino Médio}

Os Projetos consistem em um trabalho de pesquisa na Internet de língua francesa, dentro de um tema geral proposto pelo colégio ou pela disciplina "parceira" para um evento, a respeito de sub-temas, escolhidos por duplas de alunos. Esse trabalho de pesquisa compreende leitura de um número variável de textos sobre o mesmo assunto (ao menos dois, com citação dos endereços), seleção e adaptação de trechos e montagem de uma apresentação de Power Point, compreendendo texto em francês, ilustrações e animação, para exposição e explicação em português ao público do evento. A aplicação dos projetos já está em seu terceiro ano, e deve ser intensificada a partir de 2009, estendendo-se a outras séries e disciplinas.

\section{O trabalho acadêmico}

Coisas diferentes são um projeto bem sucedido e sua análise acadêmica adequada. Cada ponto da preparação, execução ou avaliação dos resultados me levou a um número muito grande de aspectos a considerar, conceitos e caminhos teóricos. Ampliar sempre o horizonte da pesquisa foi agradável e mesmo apaixonante (vício hipertextual!). Penoso foi tratar os pontos básicos com a necessária profundidade e dar a 
essa análise uma linha objetiva e coerente... Ouso esperar que o presente trabalho mostre a riqueza dos fatores envolvidos: a leitura e seu papel no aperfeiçoamento da competência de comunicação em Francês Língua Estrangeira (FLE), a Internet - a grande biblioteca universal, os projetos de aprendizagem, com suas características de trabalho em autonomia e interdisciplinaridade. E apresente sugestões úteis para o uso da Internet no ensino/aprendizagem de Francês em contexto institucional. 


\section{Capítulo I - Natureza da leitura em FLE}

\section{Objetivo da leitura: a compreensão}

Para bem delinear o problema da compreensão de leitura, comecemos por definir o que é compreensão, de maneira geral, que nós chamaríamos aqui compreensão do mundo. Segundo Fayol e Gaonac'h (2003: 5, 6), a compreensão é uma atividade, e não simplesmente o resultado dessa atividade, "um processo dinâmico que visa a integrar as informações à medida que elas são obtidas" ${ }^{\prime 13}$.

Trata-se de um trabalho que envolve a memória - que contém toda a soma de conhecimentos anteriores de que se dispõe - e o tratamento das informações novas, de forma a construir um todo coerente. Portanto, compreender significa a manipulação local dos dados novos, captados pela percepção, e global de manutenção da visão do mundo já existente e de integração dos dados novos em tempo real.

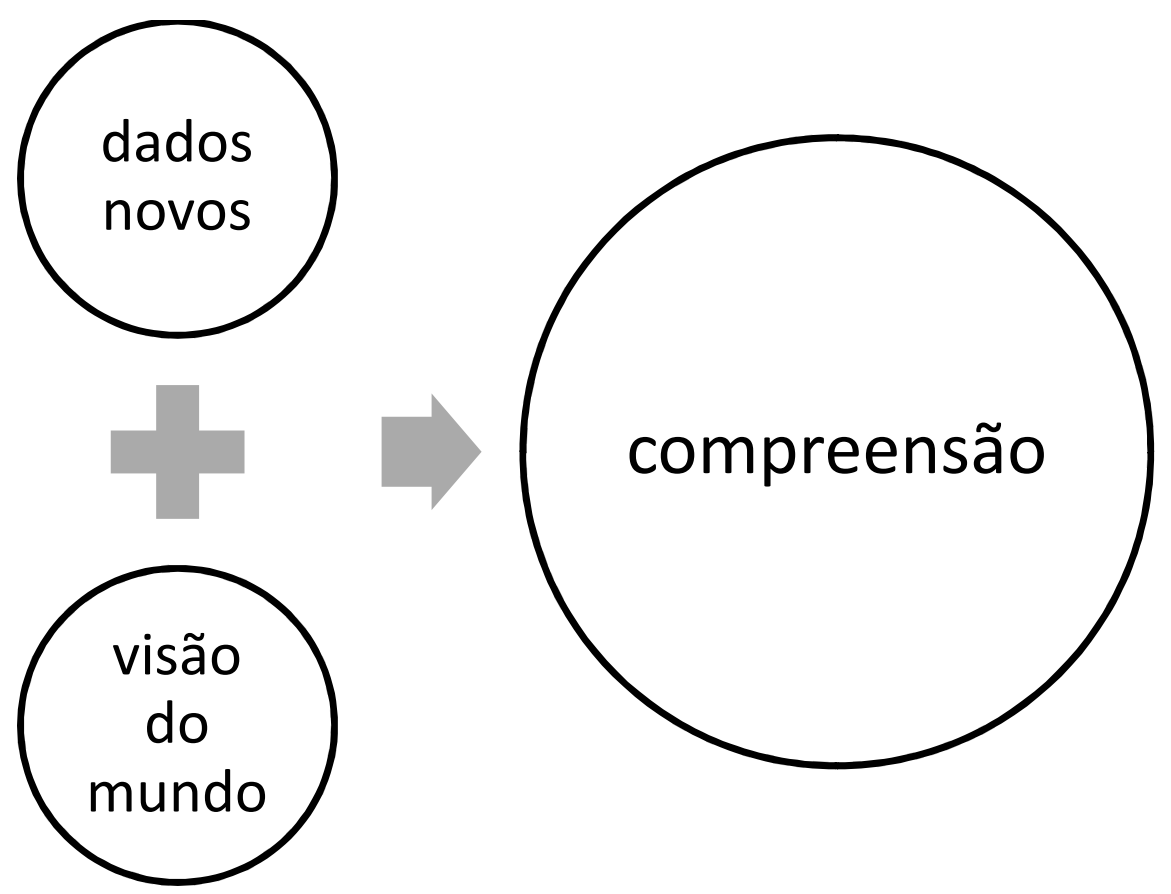

Figura 1: O que é a compreensão Baseada em Fayol e Gaonac'h $(2003: 5,6)$

13 “un processus dynamique qui vise à intégrer les informations au fur e à mesure qu'elles sont perçues." 
Essa compreensão do mundo, embora seja definida como atividade, é, em larga medida, involuntária, distinguindo-se nisso da compreensão de leitura pelo caráter voluntário dessa última.

Todo leitor busca, portanto, obter sentido através da leitura. Assim, o leitor é, como diz Cornaire (1991: 6), alguém “em busca ativa de sentido" ${ }^{14}$. Por isso afirma Sprenger-Charolles (1982: 7) : "Ler é, antes de mais nada, compreender" Fayol e Morais (2004 : 16) lembram que a compreensão dos acontecimentos da vida cotidiana, assim como da linguagem, tanto para a conversação quanto para a compreensão de textos lidos por outras pessoas, já existe antes da aprendizagem da leitura. Ler é buscar a compreensão a partir da leitura. Mais ainda, compreender é aprender. Compreender um texto é ser capaz de

"ir além das formas verbais do discurso a fim de retirar delas as idéias subjacentes, de compará-las a seus conhecimentos anteriores, de distinguir o que é essencial e novo e, assim, de atualizar sua bagagem de conhecimentos" ${ }^{16}$ (Cornaire, 1991 : 101, citando Foley).

A leitura em LE, entretanto, intervindo em um momento em que a leitura em LM já é proficiente, vai buscar a partir da leitura, ao mesmo tempo, apreender significados em um código mal conhecido, e aprofundar-se, com isso, nesse novo código.

\footnotetext{
14 "en quête active de sens".

15 «Lire, c'est d'abord comprendre ».

16 " d'aller au-delà des formes verbales du discours afin d'en repérer les idées sous-jacentes, de les comparer à ses connaissances antérieures, de distinguer ce qui est essentiel et nouveau, et ainsi de mettre à jour son bagage de connaissance ».
} 


\section{Modelos de Compreensão em Leitura}

A maneira de atingir a compreensão em leitura tem sido descrita de diferentes maneiras. Entre os muitos modelos de leitura confeccionados a partir dos anos 60 , Cornaire (1991: 22) distingue três tipos: os modelos bottom-up, ou de baixo para cima; os modelos top down, ou de cima para baixo e os modelos interativos. Para os modelos bottom-up a compreensão se constrói pela decodificação sucessiva dos menores elementos de um texto para os maiores: letras, sílabas, palavras e frases. A imagem muitas vezes empregada para descrever esse processo é a da construção de uma casa, pela justaposição de tijolos de sentido. Esse seria o conceito subjacente a uma metodologia de ensino da leitura do tipo leitura-tradução. Os modelos top-down consideram que a leitura é sempre empreendida a partir de uma hipótese prévia, de uma idéia sobre o conteúdo do texto, baseada nos conhecimentos do leitor. $\mathrm{O}$ ato propriamente de ler não seria mais que uma garimpagem de indícios, que confirmariam a hipótese inicial, ou a negariam, levando, nesse último caso, à criação de novas hipóteses. Dentro desse modelo, nos anos 70, psicolingüistas como Goodman e Smith afirmaram que a compreensão de leitura não dependia de toda informação visual fornecida pelo texto, mas de uma "leitura seletiva"17, comandada pelo cérebro, “utilizando o conhecimento conceptual e lingüístico e os esquemas que já possuem”18. O modelo bottom-up, ou semasiológico (na terminologia proposta por Coste: 1974), considera o sentido como algo emanando do texto. Já no modelo top-down, ou onomasiológico, o sentido provém principalmente do leitor. Os modelos interativos levam em conta as relações possíveis entre os dois sistemas, considerando que o leitor

\footnotetext{
${ }^{17}$ SMITH $2003: 102$.

${ }^{18}$ GOODMAN 1988: 18.
} 
apelar para várias fontes de informação no trabalho de reconhecimento das palavras: grafêmicas, lexicais, morfológicas, sintáticas, textuais ou referenciais, como explica Cornaire (1991: 24).

Uma das escolas resultantes da concepção interativa é a Abordagem Global de Leitura, apresentada no fim da década de 70 por Sophie Moirand, em sua obra Situations d'écrit (1979), Gérard Vigner (Lire du texte au sens, 1979) e Lehmann et allii (Lecture fonctionnelle de textes de spécialité, 1980), entre outros, inserindo-se na Abordagem Comunicativa. Ela surgiu em um momento em que a leitura tinha sido afastada inteiramente da metodologia de FLE, ao menos nos níveis básicos, pelos métodos áudio-visuais ${ }^{19}$, depois de um longo predomínio com os métodos do tipo gramática-tradução. Sua primeira proposta - que deu nome à metodologia - consistia em uma abordagem do texto que partia da imagem global, descendo depois - ou não em sucessivas varreduras, a níveis maiores de detalhe. Na afirmação de Lehmann (1994 : 89) em sua retrospectiva a respeito da abordagem global:

"o termo marcava, sem dúvida, que o texto deveria ser visto como um todo, como uma unidade de significação; ou ainda que se propunha fornecer ao aprendiz os meios de chegar em pouco tempo a uma compreensão grosseira, superficial, mas suficiente dos textos $^{20}$

A novidade da época, que consistia nos modelos top-down, fez com que toda a atenção fosse dada a essa entrada no texto, empobrecendo a proposta geral de leitura. Entretanto, outras das bases teóricas dessa metodologia, que apontavam justamente para

\footnotetext{
${ }^{19}$ Após um declínio com os métodos diretos e ativos.

${ }^{20}$ "le terme marquait sans doute que le texte devait être perçu comme un tout, comme une unité de signification; ou encore que l'on se proposait de fournir à l'apprenant les moyens de parvenir en peu de temps à une compréhension grossière, superficielle mais suffisante des textes. »
} 
um detalhamento do texto, são a análise do discurso, a gramática do texto e o conceito dos gêneros textuais.

A Abordagem por Competências, baseada por Béacco (2007 : 12) no Quadro Europeu Comum de Referência para as Línguas, em suas descrições da competência de leitura e posteriormente em sua metodologia da leitura, segue em larga medida as descrições da Abordagem Global:

“os descritivos dessas competências põem em jogo elementos como (...) fazer uma idéia do conteúdo do texto informativo (...) encontrar e compreender a informação pertinente nos escritos quotidianos (...) parece bastante claro que essas competências buscadas valorizam mais os saberes do tipo de cima pra baixo do que do tipo de baixo para cima." ${ }^{21}$ (Béacco 2007 : 168)

Do tipo interativo também é o atual modelo cognitivista, exposto em didática de FLE por Gaonac'h. ${ }^{22}$ Nesse modelo, a leitura é vista como um duplo processamento: primeiramente, o leitor deve estudar sucessivamente cada uma das marcas lingüísticas; em seguida, ele deve elaborar sua interpretação do que foi lido, apoiando-se sobre o significado de palavras e frases, e mobilizando, ao mesmo tempo, seus conhecimentos prévios do domínio e da língua, conduzindo essas duas atividades, em função do objetivo visado. Os diferentes níveis de representação - ou de interpretação (os autores usam os dois termos como sinônimos) seriam a identificação das palavras, o reconhecimento do léxico, o tratamento da sintaxe, o tratamento da estrutura dos textos. A ativação dos conhecimentos prévios tem um efeito importante sobre a compreensão, assim como a formulação de um modelo de situação, que integra

\footnotetext{
${ }^{21}$ « les descripteurs de cette compétence mettent en jeu des éléments tels que (...) se faire une idée du contenu du texte informatif (...) trouver et comprendre l'information pertinente dans les écrits quotidiens (...) il semble assez claire que ces compétences recherchées valorisent plûtot des savoirs du type de haut en bas que du type de bas en haut. »

${ }^{22}$ Ver Fayol e Gaonac'h (2003: 57).
} 
progressivamente - em tempo real - todos os dados que foram evocados da memória, assim como aqueles que vão sendo tratados a partir do texto. (idem : 50).

Enquanto explicação dos processos internos de leitura, parece-nos que o modelo exposto por Fayol e Gaonac'h é muito mais provável que a tese de Smith - utilizada como referência teórica na Abordagem Global - de que a leitura prescindiria, em maior ou menor grau, da informação visual, utilizando em seu lugar os esquemas de conhecimento já presentes na memória ${ }^{23}$. Do ponto de vista do ensino de leitura em FLE, entretanto, consideramos que a Abordagem Global, assim como a atual Abordagem por Competências, tem descrições muito pertinentes para a leitura com Internet.

\section{Ler em LE: especificidades no acesso ao sentido}

Ao tratar da leitura em língua estrangeira, entendemos aquela leitura que se efetua com o objetivo de aprender a $L E$, em textos cujo vocabulário e conteúdo não são dominados pelo leitor, às vezes longe disso, e não simplesmente uma leitura que revele o nível de conhecimento já adquirido pelo leitor em outras áreas da LE. Nosso interesse é, portanto, investigar como se processa essa leitura-aprendizagem em LE.

No aprendizado da leitura em LM, ou alfabetização, o aluno domina o sistema lingüístico e suas dificuldades se situam no conhecimento e automatização do código escrito. Na leitura em LE de que tratamos, os mecanismos da leitura e o código alfabético já são dominados pelo aluno, embora o código ortográfico, que é específico

\footnotetext{
${ }^{23}$ Lehmann (1994 : 88) reporta a famosa frase de Franck Smith: "Ler é dar sentido a um texto."
} 
para cada língua, possa trazer dificuldades. O que mais falta, entretanto, em grau maior ou menor, é o domínio do próprio sistema lingüístico.

A atividade de leitura (em LM) foi descrita como uma articulação de mecanismos que devem ser postos em funcionamento de maneira conjunta para que resulte em uma compreensão adequada. Tais processos são, basicamente, os de baixo nível como a identificação de palavras, seu reconhecimento lexical, o tratamento da sintaxe e da articulação das frases e o tratamento da estrutura dos textos - os de alto nível, como o recurso ao contexto, a antecipação, a inferência, a ativação dos conhecimentos do mundo e dos modelos mentais; assim como os chamados tratamentos integrativos, que visam a construção de "uma representação coerente da significação do texto" 24 (GAONAC'H 2003 : 146), e nos quais consiste, propriamente, a compreensão.

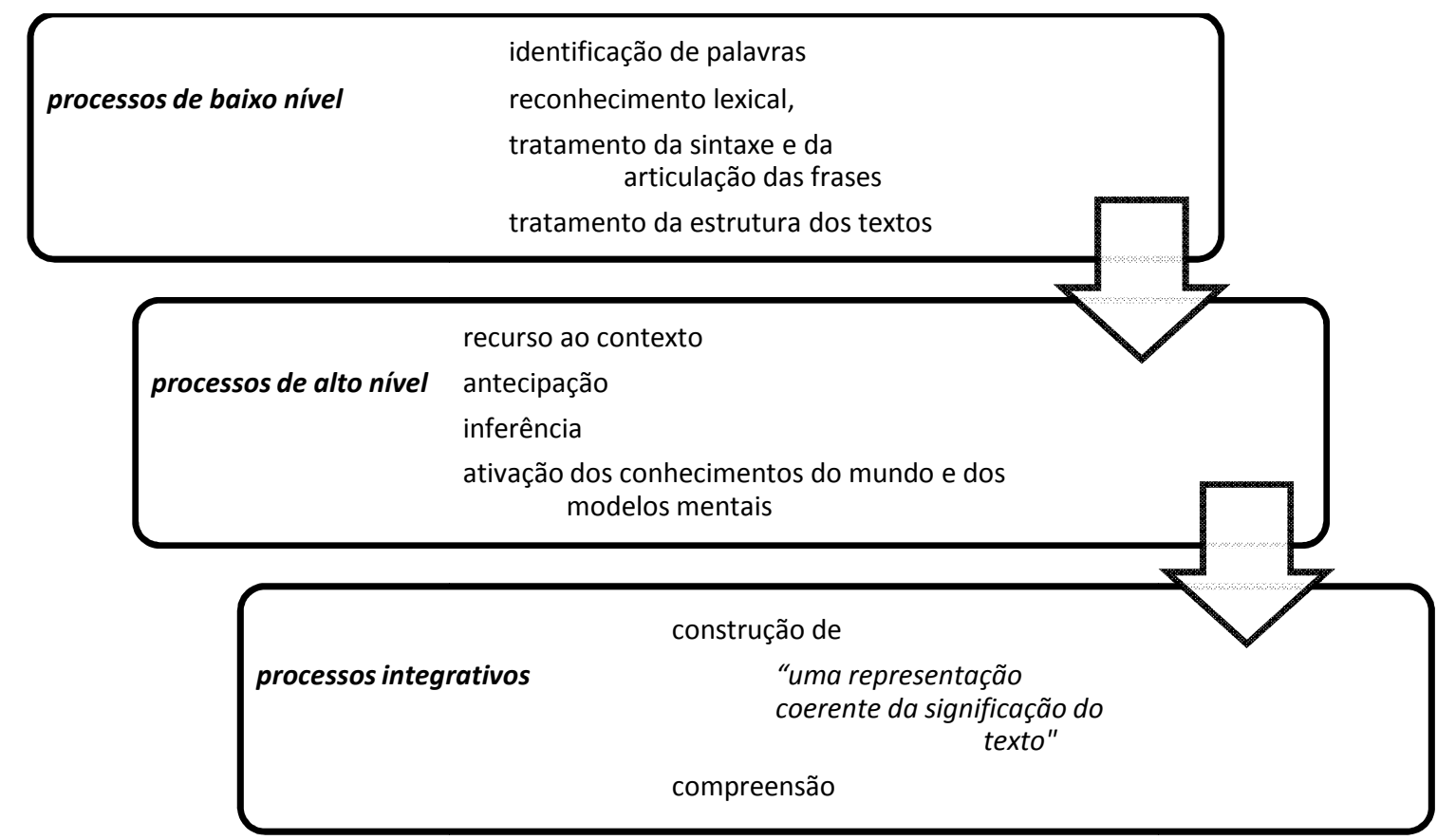

Figura 2: Processos constitutivos da leitura - Baseado em Gaonac'h 2003 : 146.

24 “une répresentation cohérente de la signification du texte”. 
O desempenho deficitário de algum ponto do sistema produz uma "sobrecarga" da memória de trabalho, que impede a compreensão. Gaonac'h, (2003: 141) considera que o ponto fraco do sistema da leitura em LE é a baixa automatização dos processos de baixo nível e um recurso, conseqüentemente, desequilibrado aos processos de alto nível:

"O leitor em língua estrangeira, como o mau leitor em língua materna, não é aquele que evita, por exemplo, todo efeito de contexto. Pode ser mesmo que os efeitos de contextos sejam muito grandes (com uma tendência à "adivinhação"), mas as dificuldades, para esses leitores, parecem ser de assegurar simultaneamente um controle nos níveis mais baixos do sistema, sem dúvida porque (...) esses níveis não funcionam de maneira eficaz." 25

Dos diversos processos de baixo nível, o mais decisivo para a compreensão é a chamada identificação lexical, ou seja, o "emparelhamento" da palavra com seu significado, armazenado previamente no léxico mental. As palavras memorizadas através da leitura, como mostram Fayol e Gaonac'h (2003:17), serão acrescentadas ao léxico mental, espécie de dicionário particular, aonde vão sendo guardados, desde a primeira infância, todos os termos aprendidos pelo indivíduo, nas modalidades conceito, imagem sonora e forma ortográfica, tanto em língua materna quanto em língua estrangeira. As palavras, no léxico mental, não estão armazenadas de forma isolada, nem em ordem alfabética, p.ex., como em um dicionário. Elas estão organizadas principalmente em redes semânticas - além de outros critérios, como a função sintática, a morfologia e características sonoras, como as rimas - e a ativação de uma palavra,

\footnotetext{
25 «Le lecteur en langue étrangère, comme le mauvais lecteur en langue maternelle, n'est pas celui qui évite, par exemple, tout effet de contexte :il se peut même que les effets de contexte soient plus grands (tendence au 'devinement'), mais les difficulté pour ces lecteurs semble être d'assurer simultenément un contrôle aux niveaux plus bas du système sans doute parce que(...) ces niveaux ne fonctionnent pas de manière efficace. » (COIRIER, GAONAC'H, PASSERAULT 1996 : 213)
} 
pela leitura, provoca uma espécie de "prontidão" das palavras de sentido próximo, que serão reconhecidas mais facilmente, se aparecerem no texto.

Conclusão evidente, comprovada por experiências ${ }^{26}$, o conhecimento do léxico influi diretamente sobre a compreensão de textos. Entretanto, os pesquisadores não estão de acordo sobre a eficácia de um ensino sistemático de vocabulário sobre as habilidades de leitura. O que é certo é que os bons leitores fazem acréscimos rápidos no seu léxico mental e isso lhes permite ler ainda melhor. Os que leem pouco, por outro lado, aumentam menos seu vocabulário e conservam suas deficiências de leitura. Fayol e Gaonac'h (2003: 21), lembrando a descrição desse fenômeno, chamado Efeito Mateus por Stanovich (1986) : “Os ricos se tornam cada vez mais ricos e os pobres cada vez mais pobres”, afirmam que "a prática da leitura é o meio mais seguro de aumentar o capital lexical e, portanto, de favorecer, por sua vez, a capacidade de compreensão" 27 .

A quantidade de palavras estocadas no léxico mental do leitor tem, portanto, um efeito conhecido sobre sua capacidade de leitura, tanto em LM quanto em LE. Ora, em se tratando de leitores aprendizes de LE, e até mesmo de absolutos iniciantes, como poderá se dar o processo de leitura? De toda forma o leitor tentará a identificação lexical. Esta pode ocorrer por reconhecimento da forma ortográfica da palavra, hipótese em que uma forma sonora e uma forma semântica são ligadas, em questão de milissegundos, à forma ortográfica já presente no léxico mental. Se não houver, entretanto, tal forma global escrita armazenada previamente, o leitor tentará o reconhecimento transformando a seqüência de letras em uma cadeia sonora - a forma fonológica - à procura não mais de uma palavra lida, mas sim de uma palavra ouvida.

\footnotetext{
${ }^{26}$ Citadas por Fayol e Gaonac'h (2003 : 17

${ }^{27}$ " la pratique de la lecture est le plus sûr moyen d'augmenter le capital lexical et donc de favoriser en retour la capacité de compréhension »
} 
O conhecimento dos sistemas fonológico e ortográfico, em um nível mínimo, é importante, portanto, para que o aprendiz leitor em LE possa introduzir em seu léxico mental as palavras aprendidas na leitura, em sua forma escrita, acompanhadas de uma adequada representação fonológica. Ainda que não se deva esperar, evidentemente, para ler, pelo domínio completo desses códigos. A subvocalização, ou leitura em voz baixa do texto escrito em língua estrangeira, embora tenha sido freqüentemente condenada no ensino de LE, é excessivamente generalizada para que possa ser considerada uma leitura desviante, mostrando-se, pelo contrário, como uma estratégia válida para o acesso ao sentido (para um exemplo de combate infrutífero a esse procedimento, veja-se a tese de Pham, 2001: 8).

Por outro lado, sendo a forma escrita das palavras em francês mais próxima do que a forma sonora das palavras correspondentes em português, podemos supor, como fez Hilton (2003 :1) comparando o inglês e o francês, que o acesso lexical das palavras francesas através da forma escrita, seja mais fácil para o leitor cuja língua materna seja o português, do que através da forma sonora. Jover (2006 : 67) confirma tal hipótese, comprovada freqüentemente no quotidiano de nosso ensino de FLE.

Como vimos acima, os termos arquivados no léxico mental, tem "entradas" também por critérios morfológicos e sintáticos. A carga de significado que é transmitida pelas formas gramaticais - plurais, gêneros, formas verbais, referências construídas sobre pronomes etc. - conhecida pelo aprendiz leitor em sua LM, será bastante útil na compreensão de leitura em LE, caso ele possa perceber as equivalências. Um ensino gramatical voltado para a compreensão, como o proposto por Courtillon (2004 : 1) deverá levar em conta esses aspectos. A semelhança morfológica, pela presença de radicais latinos, em palavras francesas e portuguesas, também poderá ser aproveitada para a descoberta do sentido da palavra. Por outro lado, certas discrepâncias entre o 
sistema gramatical da LM e da LE podem causar dificuldades de compreensão. Também nesse caso, segundo Courtillon (idem), essas estruturas devem ser objeto de uma explicitação.

Os criadores dos modelos de leitura top-down, da década de 70, atribuíam um papel primordial ao contexto no âmago do processo de leitura, ou seja, na própria identificação lexical. Segundo eles, a compreensão de leitura se daria pela confirmação de hipóteses prévias, baseadas sobretudo nos esquemas mentais (na expressão devida a Shank e Abelson 1977). Ora, de acordo com os modelos cognitivistas (como o de Fayol e Morais 2004 : 47) o leitor fluente em língua materna identifica palavras com tal velocidade que não há tempo para a intervenção do contexto. Já os leitores menos competentes apóiam-se no contexto, incorrendo, por isso (ou apesar disso?), em mais erros de interpretação.

Nota-se claramente, entretanto, na leitura de nosso aprendiz em LE, que o recurso ao contexto é uma de suas principais "tábuas de salvação" - ou estratégias cognitivas - empregadas. Isso poderia ser atribuído à exigüidade do léxico mental desses aprendizes, no qual um número excessivamente grande de palavras fundamentais para a compreensão de um texto não tem nenhuma representação. Nesse caso, o progresso no aprendizado faria com que desaparecesse essa atitude. Outra possibilidade é considerar o recurso ao contexto como uma estratégia de construção de sentido normal e válida, se adequadamente empregada, em qualquer fase do aprendizado da LE, visto que, muitas vezes, no transcorrer da própria leitura, novos termos são encontrados pela primeira vez, compreendidos e incorporados ao léxico mental, através de um exame do contexto. 
A utilização do contexto em leitores aprendizes de LE se dá de várias formas, conforme observações de Pietraróia (1997 : 120, 276 passim). Um primeiro comportamento consiste na ativação, de modo rápido, de um modelo mental do assunto que o leitor pode identificar no texto, passando a atribuir sentidos, com base nesse modelo, a todas as sequiências incompreensíveis, com um mínimo de atenção às palavras. A interpretação avança em meio a "generalizações, supressões e inferências nas leituras feitas pelo leitor, mas não autorizadas pelo texto". Curiosamente, essa atitude convive com certa satisfação com a própria interpretação e a noção de que a leitura "não oferecia grandes problemas de compreensão".

Outra forma de recurso ao contexto consiste em tomá-lo como árbitro entre as várias possibilidades de sentido levantadas pela associação de um termo em LE, seja com termos da LM semelhantes por critérios gráficos, morfológicos ou fonológicos, seja com outros termos da LE já estabilizados no léxico mental. Esse tratamento, denominado pela autora (op.cit.: 277) formal-semântico, pois leva em conta as características formais da palavra e as exigências semânticas do contexto, é executado “não em função mas pela consideração dos dados tomados nos contextos imediato e global” (idem : 281), com apoio formal na palavra.

$\mathrm{Na}$ primeira dessas atitudes, não se pode falar em aquisição lexical pois "não havendo percepção formal do termo, não pode haver memorização do mesmo e, a cada nova ocorrência, o leitor terá que usar estratégias custosas para construir seu sentido" (idem : 283). Por outro lado, a tentativa de identificação de um termo pelo processo formal-semântico, se bem sucedida, leva à construção de um sentido mínimo para a palavra e à sua entrada no léxico mental. Se, entretanto, não há atribuição de sentido à palavra, pode haver, ainda assim, a manutenção na memória da forma trabalhada para seu posterior reconhecimento semântico. 
Giasson (1990: 14 e 15) inclui as estruturas afetivas do leitor nas variáveis que atuam sobre o ato de ler. Segundo ela, tudo o que diz respeito não àquilo que o leitor pode, mas ao que ele quer fazer, são efeitos da afetividade. De fato, a atração, a indiferença ou a repulsa do leitor por determinado texto ou pela leitura em geral, representam um papel primordial na compreensão.

A percepção da distância que existe entre LM e LE é também um ponto fundamental na motivação do aprendiz para a passagem de uma língua a outra. Se essa distância é vista como intransponível, ela evidentemente, não será transposta. Por outro lado, a noção de proximidade entre as línguas leva a um trabalho mais ativo e pessoal de busca de semelhanças e diferenças e à transferência autônoma dos fatos da língua descobertos.

Segundo demonstrado em pesquisas, bons leitores são, ao mesmo tempo, aqueles que se consideram os agentes de seu próprio sucesso e aqueles que empenham mais tempo e mais recursos estratégicos no trabalho. Nos maus leitores, portanto, a menor aplicação à tarefa constatada é, em grande parte, devida a um sentimento adquirido de impotência ${ }^{28}$ (Fayol e Gaonac'h 2003 :71 citando Chartier e Lautrey 1992), pelo qual o fracasso é atribuído não à falta de esforço, mas à falta de capacidade. Esse sentimento de incapacidade, que paralisa os esforços do aprendiz, assim como toda uma gama de sentimentos positivos e negativos que movem ou impedem a ação, como a capacidade de correr riscos, o conceito de si e o medo do fracasso, devem ser objeto de uma atenção particular.

A atitude diante de um texto pode ser profundamente determinada também pelo interesse particular que lhe consagra o leitor. Pois o primeiro objetivo do ato de ler é,

28 “sentiment acquis d'impuissance" 
como vimos, compreender a mensagem. Se esta é desprovida de interesse, não há porque enfrentar o trabalho da leitura. Na formulação de Vigner (1979) : "Ler é um ato de comunicação entre um texto e um leitor, entre os elementos formais do primeiro e o projeto de leitura e os conhecimentos do segundo"29. A afirmação do caráter comunicativo da leitura em LE leva a uma questão interessante: na comunicação, a prioridade é normalmente a compreensão da mensagem. Ora, se há algo a ser dito, por que não dizê-lo em LM? Para quebrar, portanto, a artificialidade da comunicação em aprendizado de LE é preciso algo que realmente deva ser dito, ou seja, uma mensagem com conteúdo de fato interessante, e mais ainda, que não possa ser transmitida em LM. Por outro lado, se a prioridade é a compreensão, o código em que vem expressa a mensagem tende a ser esquecido, após sua decifração. No entanto, o real objetivo do ensino é o código! Daí a utilidade de um trabalho metalingüístico sobre as formas, gerador de compreensão, minucioso, atento... - acompanhando de perto a leitura (Pietraróia 1997: 300).

\section{Abordando a leitura em FLE}

Após um exame dos aspectos mais interessantes dos mecanismos de leitura tal como descritos por várias escolas diferentes, detalharemos duas abordagens que nos parecem mais produtivas, não para todo e qualquer ensino de leitura em FLE, mas apenas para o tipo de trabalho que adotamos.

A Abordagem Global de leitura, mais que um estudo dos mecanismos de leitura ou das estratégias cognitivas do leitor para chegar à compreensão de um texto, foi uma

\footnotetext{
${ }^{29}$ «Lire est un acte de communication entre un texte et un lecteur, entre les éléments formels du premier et le projet de lecture et les connaissances du deuxiéme».
} 
proposta pedagógica de leitura em LE. Algumas de suas descrições, interessantes para a leitura em papel, ganharam novo relevo com o advento da leitura em Internet. A Abordagem por Competências, por sua vez, recebe sua importância do fato de ser uma chave de compreensão do enfoque utilizado para a criação do Quadro Europeu Comum de Referência para as Línguas, documento de referência inescapável no atual ensino de línguas. A adoção de muitos pontos da metodologia global pela nova Abordagem por Competências nos leva a tratar em seqüência suas propostas.

Diante de um texto, dois tipos básicos de leitura, não excludentes, podem ser empreendidos: a leitura integral e a leitura seletiva. A originalidade da Abordagem Global é o reconhecimento de que, se a primeira foi a única praticada desde sempre em aula de LE, a segunda é contemplada em grande número de situações de leitura em LM e pode ser proposta com utilidade para a aprendizagem de leitura-compreensão em LE.

Moirand (1979 : 51) considera que os textos devem ser, sempre que possível, longos, pois “na realidade cotidiana, um leitor em busca de informações encontrará raramente textos (...) de vinte linhas ${ }^{\text {30 }}$ Ora, a leitura-decifração de um texto longo em LE pode levar rapidamente à desistência... Daí a vantagem de ensinar estratégias de leitura seletiva, sendo essa última definida como

"uma estratégia de leitura correspondendo a objetivos diferentes: buscar uma informação, percorrer em diagonal ou écrémer um texto para buscar a passagem que se quer ler de maneira integral etc. ${ }^{, 31}$

Não se trata aqui de ler mais ou menos bem, já que

\footnotetext{
${ }^{30}$ "dans la réalité quotidienne, un lecteur à recherche d'informations rencontrera peu souvent des textes (...) de vingt lignes. »

${ }^{31}$ " une stratégie de lecture correspondant à des objectifs différents: rechercher une information, parcourir en diagonale ou écrémer un texte pour aller chercher le passage qu'on veut lire de manière intégrale etc. »
} 
"se pode ler mais ou menos seletivamente, com a mesma eficiência, conforme a experiência que se tem do tipo de textos abordados e os conhecimentos que se possui da área de referência",32

O “objeto" a ser tratado pela leitura é o documento, segundo Vigner (1980 : 138139), ou seja,

"um conjunto construído de signos de naturezas diversas (icônicos, graficos, tipográficos, linguísticos) destinados, por sua convergência e pela unidade da apresentação material, a produzir um efeito de sentido, a transmitir um certo número de informações". ${ }^{33}$

$\mathrm{Na}$ Abordagem Global, o documento pode pertencer a gêneros extremamente variados, como dicionários, textos literários, artigos científicos, textos de imprensa, catálogos, formulários, cartazes, avisos, textos de publicidade e outros ${ }^{34}$. No interior desses textos,

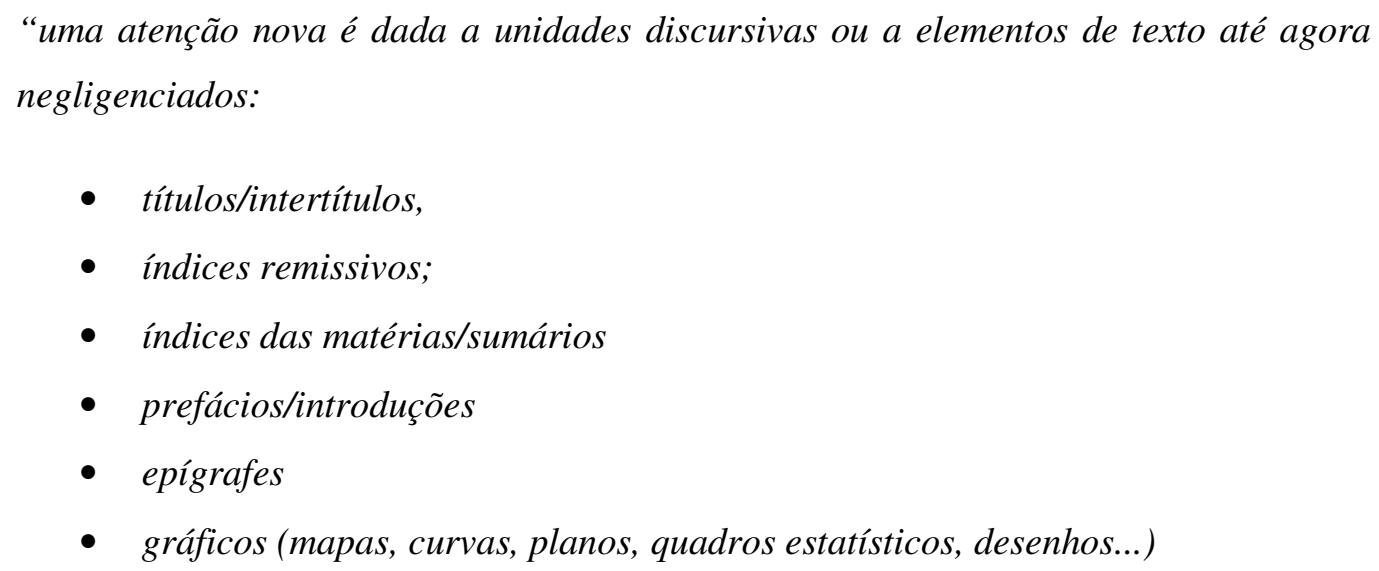

\footnotetext{
${ }^{32}$ « on peut lire plus ou moins sélectivement, avec la même efficacité, selon l'expérience que l'on a du type de textes abordés et les connaissances que l'on possède du domaine de référence » p.22.

33 « un rassemblement construit de signes de natures diverses (iconiques, graphiques, typographiques, linguistiques) destinés, par leur convergence et par l'unité de la présentation matérielle, à produire un effet de sens, à transmettre un certain nombre de informations » ${ }^{34}$ vide VIGNER (1980 : 139).
} 
- imagens (fotografias e legendas, desenhos metadiscursivos...),35

Tendo como suporte esses textos de natureza e elementos variados, muitos tipos de leitura podem ser praticados em aula. A primeira abordagem deve ser de coleta de

“índices textuais permitindo, de um lado fazer previsões sobre a arquitetura do texto e formular hipóteses sobre seu sentido, de outro lado, verificar no próprio texto as hipóteses feitas" 36 . Ora, "é certo que, quanto mais os textos são longos, mais os indícios textuais necessários à descoberta do sentido e da lógica do discurso estarão disseminados, entremeados e mesmo amontoados na área do texto ${ }^{, 37}$.

As técnicas utilizadas para efetuar esse mapeamento do texto são chamadas :

- varredura, única ou repetida,

- sobrevôo do texto, durante o qual o olho captura um detalhe pertinente para análise,

- 'écrémage', na qual, p.ex.se colecionam certos elementos salientes, como os subtítulos,

- $\quad$ sondagem, na qual se procura determinado termo ou expressão pertinente para a compreensão,

\footnotetext{
35 « une attention nouvelle [est] portée à des unités discursives ou des éléments de texte jusqu'alors negligés:

- $\quad$ titres/intertitres

- index des matières

- $\quad$ tables des matières/sommaires

- préfaces/introductions

- épigraphes

- $\quad$ graphiques (cartes, courbes, plans, tableaux statistiques, dessins...)

- images (photographies et légendes, dessins métadiscursifs...)»

36 « indices textuels leur permettant d'une part de faire des prévisions sur l'architecture du texte et de formuler des hypothèses sur son sens, d'autre part de vérifier dans le texte lui-même ces mêmes hypothèses de prévision » $\mathrm{p} .53$

37 «il est certain que plus les textes supports sont longs, plus les indices textuels nécessaires à la découverte du sens et de la logique du discours seront disséminés entremêlés, voire enchevêtrés sur l'aire du texte ».p. 53
} 
- exploração, ou leitura mais intensiva de um trecho no qual foram encontrados indícios interessantes.

As fases propostas por Moirand (1979 : 24) para a leitura de um documento são as seguintes :

- "percepção dos signos visualmente predominantes: parte-se dos significantes, pois todo texto escrito tem uma função icônica (...) e as fotos, os desenhos, os títulos, os efeitos tipográficos são todos signos pertinentes em uma abordagem global (...)

- reconhecimento das palavras-chave e dos pontos fortes do texto (...)

- a partir desses pontos de referência, busca da arquitetura do texto e reflexão sobre as funções desses elementos (...)

- intervenção de dados sociológicos, políticos, culturais etc (em todo caso, dados extralínguísticos) (...)”38

A sequência possível do processo de leitura não é única :

“dependerá muito do projeto de leitura inicial: pode ser que uma apreensão global seja suficiente para o leitor, mas esse último pode também ter necessidade de efetuar sobre certas passagens do texto uma leitura mais fina, mais detalhada, mais linear e, por que não?, uma tradução". 39

Nossa referência à Abordagem Global deveu-se, inicialmente, à muito curiosa semelhança entre os procedimentos de leitura descritos por ela e aqueles que observamos no estudo da hiperleitura e na experiência de nossos projetos de leitura em

\footnotetext{
$38 \bullet$ • perception des signes visuellement prégnants : on part des signifiants car tout texte écrit a une fonction iconique (...) et les photos, les dessins. les titres, les effets typographiques sont autant de signes pertinents lors d'une approche globale (...)

- repérage des mots clés et des points forts du texte (...)

- à partir de ces points de repère, recherche de l'architecture du texte et réflexion sur les fonctions de ces éléments (...)

- intervention de données sociologiques, politiques, culturelles etc (en tout cas extra-linguistiques) (...)»

39 " dependra fortement du projet de lecture initial : il se peut qu'une apréhension globale suffise au lecteur, mais ce dernier peut également avoir besoin d'effectuer sur certains passages du texte une lecture plus fine, plus détaillée, plus linéaire et pourquoi pas une traduction» p.53
} 
FLE na Internet. Cremos, entretanto, que é preciso levar em consideração a advertência de Jover (2006 : 85), para quem:

“a abordagem global (...) aponta para certo esgotamento (...) [pois] os novos leitores, nascidos sob a égide da informática, dos jogos eletrônicos, da Internet, do zapear televisivo (...) talvez sejam pouco exigidos nos cursos que the são oferecidos (...) o desafio em relação a eles nos parece implicá-los em leituras menos globais, menos acessíveis em uma olhada rápida".

Por isso, longe de pensar em estabilizar as práticas de leitura de nosso aluno, contamos utilizar como estratégia no processo pedagógico uma das máximas de Santo Inácio de Loyola : "entremos com a deles para sair com a nossa", ou seja, façamo-lo apreciarem a leitura em FLE no ritmo deles, do modo que é natural para eles. Depois os levaremos a uma reflexão maior e um aprofundamento...

A Abordagem por Competências, ao adotar aspectos da Abordagem Global, insere-se na tradição de um enfoque específico para o tratamento da leitura no ensino de FLE. O Quadro Comum Europeu de Referência para as Línguas, comenta Béacco (2007 : 10), adota o conceito de que

"o conhecimento de uma língua estrangeira não é um todo indissociável ('conhecer a língua”), mas que pode ser considerado como um conjunto de elementos que é possível distinguir e identificar e que confirmam "a pertinência de metodologias de ensino concebidas especificamente competência por competência". ${ }^{40}$

\footnotetext{
40 «la connaissance d'une langue étrangère n'est pas un tout indissociable ( connaître la langue »), mais que celle-ci peut être considérée comme un ensemble d'éléments qu'ils est possible de distinguer et d'identifier e que confirmam "la pertinence de méthodologies d'enseignement conçues spécifiquement compétence par compétence ».
} 
Por isso prevê, ao lado dos programas de aprendizagem globais, outros programas modulares, ponderados ou parciais $^{41}$, nos quais objetivos bem determinados, serão tratados separadamente em níveis diferentes. Como atividades lingüísticas fundamentais, o Quadro Europeu distingue aquelas de recepção, interação, produção e mediação. Entre as atividades ditas de recepção, encontram-se a escuta ou compreensão do oral, a leitura ou compreensão do escrito e a recepção áudio-visual.

A característica determinante da leitura, segundo Béacco, consiste no fato de que se trata de um ato social deliberado, dotado portanto de uma intenção ou finalidade, a qual determina previamente o próprio modo de leitura, desde a pesquisa específica de uma informação em um texto, até a busca de conhecimentos, ou finalidades ainda mais gerais, de natureza estética, filosófica, morais, lúdicas ${ }^{42}$. Em certa medida, há uma correlação entre os tipos de leitura e os gêneros de textos:

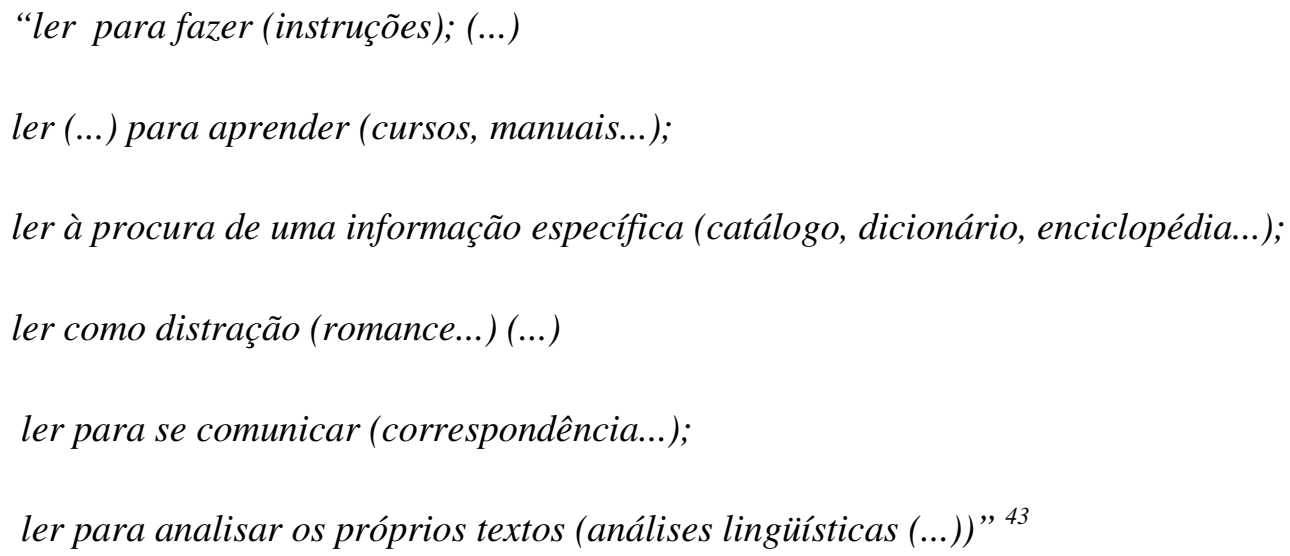

\footnotetext{
${ }^{41}$ Quadro Comum Europeu de Referência para as Línguas, edição francesa, p.12.

${ }^{42}$ Os termos em itálico encontram-se em Béacco (2007 : 170)

43 «- lire (...) pour faire (instructions/mode d'emploi) ; (...)

- lire (...) pour apprendre (cours, manuels...) ;

- lire à la recherche d'une information spécifique (catalogue, dictionnaire, encyclopédie...) ;

- lire comme distraction (roman...) (...)

- lire pour comuniquer avec des proches (correspondance...);

- lire pour analyser les textes eux-mêmes (analyses linguistiques...) »
} 
Nesse contexto, há que se considerar um bom leitor "aquele que é capaz de adaptar sua capacidade de leitura ao projeto adotado" $" 44$, empregando

“comportamentos de recepção variados: compreensão parcial de elementos do texto (ou de um só), compreensão de diferentes elementos do texto não necessariamente postos em evidência por este (varredura e 'écremage'), recepção com uma atenção forte e constante ou intermitente e variável, compreensão global ou palavra por palavra."

Compete à metodologia de língua estrangeira criar o quadro que permita contemplar essa diversidade de modos de recepção, integrando-os em uma função social compatível com a natureza dos textos, sem reduzi-los a simplesmente "ler para aprender a ler”. Igualmente certas capacidades, postas em ação conjuntamente, são necessárias, em diversas medidas, segundo o modelo do Quadro Europeu, para esse modo de recepção de textos, e compete ao ensino ativá-las e desenvolvê-las no trato com textos em língua estrangeira:

\section{“1. O reconhecimento dos dados materiais dos textos (...)}

3. A capacidade de buscar, seja na leitura linear, seja na superfície visual do texto, indícios textuais (formas lingüísticas), contextuais (espaço no qual o texto está inserido), co-textuais (títulos, ilustrações, esquema).

4. 5. e 6. A antecipação e a construção de hipóteses de sentido (...) globais e locais, a partir de conhecimentos relativos à língua (léxico e morfosintaxe), à situação, ao autor, e dos indícios levantados, e a modificação dessas hipóteses em função de novos indícios.

7. A capacidade de interpretar socialmente e culturalmente os conteúdos e, eventualmente, as formas discursivas ${ }^{45}$.

\footnotetext{
${ }^{44}$ Béacco (idem : 172)
} 
O forte embasamento dessa abordagem sobre os conhecimentos anteriores do leitor exige, evidentemente, noções claras da natureza e extensão desses conhecimentos, tanto textuais e lingüísticos quanto enciclopédicos - sobretudo em termos daquilo que o leitor não conhece - para permitir guiar sua compreensão.

Entre os motivos que recomendam a adoção desse tipo de estratégia está a atitude psicológica do aprendiz iniciante em língua estrangeira - inteiramente particular em relação a outros tipos de aprendizagem - que o leva a sofrer de um sentimento de privação de sua habilidade lingüística e da expressão de seus conhecimentos de mundo que era feita em língua materna. Trata-se de devolver-lhe o uso dos recursos cognitivos de que dispõe, "privilegiando atividades em que ele seja capaz de obter sentido, mesmo sem domínio de todos os elementos lingüísticos considerados necessários para isso" ${ }^{\text {46 }}$. Dentro desse objetivo, toda a variedade de formas de leitura propostas tradicionalmente pela Abordagem Global pode ser mobilizada para conduzir, gradualmente, o neo-leitor em língua estrangeira de leituras baseadas principalmente no conhecimento do mundo para outras que exigem um conhecimento mais aprofundado da língua.

\section{Conclusão do Capítulo I}

Como vimos, portanto, a leitura como meio de aprendizado da LE distingue-se da leitura em LM pelo baixo domínio inicial do sistema lingüístico na primeira. Sendo a identificação lexical o processo mais importante para a compreensão de leitura, a extensão do léxico mental é decisiva para a leitura eficiente; entretanto, a própria leitura

\footnotetext{
45 (idem : 174)

46 (idem : 185)
} 
é o melhor meio de adquirir vocabulário. O acesso lexical através da forma escrita traz vantagens, graças a semelhanças entre o francês e o português, assim como os traços semânticos contidos nas formas gramaticais, desde que haja um ensino gramatical voltado para a compreensão. O papel do contexto na compreensão de leitura não deve ser exclusivo dos maus leitores, mas apoiando-se sempre numa análise formalsemântica da palavra, revela-se uma estratégia válida para todo aprendiz. No enfoque que adotamos, a língua materna é vista como a base lingüística sobre a qual será construído o sistema da língua estrangeira adquirida, sendo fundamental, para o aprendizado, a percepção das relações recíprocas entre ambas. Igualmente uma comunicação real em LE, dentro de um contexto interessante, influi positivamente na aquisição, desde que haja, paralelamente, um trabalho sobre o código, em seu aspecto formal. Com respeito à maneira com que se deve ler um texto em aula de LE, a abordagem global propõe o ensino de técnicas de leitura em vários níveis de detalhe, evitando o monopólio da leitura integral e linear, que inviabiliza a leitura de textos longos. A abordagem por competências, por sua vez, ressalta o caráter deliberado da leitura como ato social e a determinação de sua forma pela finalidade adotada, propondo a organização de um ensino de leitura que contemple essa diversidade de objetivos e modos de leitura, mobilizando, através dela o conhecimento de mundo e a competências de leitura do aprendiz.

Investir na leitura como meio de aprendizado da LE, não exclusivo evidentemente, é vantajoso e possível, desde as etapas iniciais e, como veremos, uma atividade grandemente favorecida pelo advento da informática na educação. 


\section{Capítulo II - Internet}

\section{Por que Internet?}

A condição prévia a nosso trabalho era que ele fizesse referência à Internet ${ }^{47}$. Essa solicitação é do maior bom senso, já que não é possível ignorar simplesmente a “onda" tecnológica em Educação. De fato, há “expectativas e exigências" 48 do público, como lembram Barbot e Pugibet (2002 : 4), há o discurso dos governos e da mídia pregando a necessidade da "inclusão digital" como remédio seguro para as deficiências da educação, mas há poucos estudos e propostas de uso baseados em dados reais, como mostra o trabalho de Dwyer, Weiner et allii (2007) ${ }^{49}$. Mas, na formulação de Maguy Pothier (2003 : 121),

"não é mais possível, na hora atual, de agir como se as tecnologias não existissem, mas essas últimas devem estar a serviço da didática e da pedagogia: é o projeto que deve induzir a utilização das técnicas e não o inverso." 50

Por outro lado, o ensino de línguas estrangeiras é, tradicionalmente, associado ao uso das tecnologias ${ }^{51}$. A presença da Internet na escola é uma boa ocasião para experimentar:

\footnotetext{
${ }^{47}$ Essa condição foi explanada na Introdução, p. .

48 "attentes et exigences"

49 “As políticas públicas brasileiras que favorecem a introdução de computadores nas escolas parecem estar baseadas na hipótese de que o uso de computadores pelos alunos traria benefícios significativos para a qualidade dos ensinos fundamental e médio. Uma análise da bibliografia brasileira demonstrou a existência de uma crença, por parte de muitos pesquisadores, de que a adoção das TICs seja por si só associada com melhoras na escola. Esta 'expectativa positiva' levou à falta de pesquisa empírica para testar esta hipótese, que acabou sendo tratada como um a priori".

${ }^{50}$ «il n'est plus possible, à l'heure actuelle, de faire comme si les technologies n'existaient pas, mais ces dernières doivent être au service de la didactique et de la pédagogie : c'est le projet qui doit induire l'utilisation des techniques et non l'inverse ».
} 
"Diante do material disponível, há a escolha entre o pretexto e a necessidade. Às vezes, a ferramenta está à disposição, é preciso utilizá-la. (...) Você vê gente que não ousa, que tem necessidade de ser encorajada e a quem o equipamento obriga, às vezes, a dar um passo $(\ldots)^{52}$

Da parte do aluno, é inegável o apreço que dedicam à Internet, adolescentes, jovens e até crianças. Em boa parte das famílias que tem acesso à rede, os pais mostram dificuldades em controlar o tempo e o uso que seus filhos fazem do computador ${ }^{53}$. Os jovens se consideram, além disso, à frente dos adultos no conhecimento e uso que fazem da tecnologia ${ }^{54}$. Com eles, a associação da informática ao ensino da língua estrangeira, portanto, poderia trazer vantagens por três aspectos: pela motivação, pois aproxima o estudo de algo lúdico para o aluno; pela autoconfiança com que ele aborda a informática; e finalmente na sua própria capacidade de manipulação da Internet que pode tornar fácil o acesso do grupo aos recursos indicados pelo professor e - sob este aspecto - lhe permitiria trabalhar em autonomia.

\footnotetext{
${ }^{51}$ Veja-se na abordagem histórica de Puren (2001: 3), o uso do fonógrafo recomendado em aula de língua estrangeira no início do século XX!

${ }^{52}$ «Face au matériel disponible il y a le choix entre le pretexte et la necessité. Parfois, l'outil est à disposition, il faut l'utiliser (....). Vous voyez des gens qui n'osent pas, qui ont besoin d'être encouragés, et l'équipement qui oblige parfois à faire un pas(...) » SÉRANDOUR in BERTHAUX (2001: 19).

53 “Os brasileiros passaram menos tempo na internet em junho do que nos meses anteriores, mas não perderam o posto de primeiros no mundo em tempo gasto na Web, de acordo com dados do Ibopel/NetRatings.(...) Os países que mais se aproximaram do tempo residencial médio do internauta brasileiro foram a Alemanha (20h1 1min), os Estados Unidos (19h52min), a França (19h50min) e o Japão (19h31min)." wnews.uol.com.br/site/noticias/materia.php?id_secao $=4 \& i d \_c o n t e u d o=11243$ 54 "O percentual da população que possui habilidades frente o computador diminui conforme aumenta sua idade. Por exemplo, é mais fácil encontrar brasileiros que saibam usar um computador na faixa etária de 10 a 15 anos que na de 35 a 44 anos. Observa-se[entretanto] que a faixa etária de 10 a 15 anos, apesar de possuir alta proporção de indivíduos com habilidades ao computador, não supera a proporção atingida na faixa de 16 a 24 anos [ou seja, 57\% dos indivíduos dessa faixa etária em toda a população possui habilidades básicas com o computador]" TIC 2007 Habilidades com Computador e Internet Destaques : 9 .
} 


\section{O que é Internet?}

Embora a natureza da Internet e seus componentes já seja sobejamente conhecida, começaremos por defini-los.

\section{- Internet:}

"No dia 24 de outubro de 1995, o Federal Networking Council norte-americano aprovou por unanimidade uma resolução definindo o termo Internet. Esta definição foi desenvolvida em consulta com membros da Internet e comunidades de direitos da propriedade intelectual e diz o seguinte:

'Internet se refere ao sistema de informação global que -

1. é logicamente ligado por um endereço único global baseado no Internet Protocol (IP) ou suas subseqüentes extensões;

2. é capaz de suportar comunicações usando o Transmission Control Protocol/Internet Protocol (TCP/IP) ou suas subseqüentes extensões elou outros protocolos compatíveis ao IP; e

3. provê, usa ou torna acessivel, tanto publicamente como privadamente, serviços de mais alto nível produzidos na infra-estrutura descrita'

(PEREIRA 1999 : O Básico)

$\mathrm{Na}$ definição de seus criadores, a Internet é:

"um mecanismo de disseminação da informação e divulgação mundial e um meio para colaboração e interação entre indivíduos e seus computadores, independentemente de suas localizações geográficas. „55

\section{- O que significa www?}

(...) uma parte da Internet é o chamado www ou World Wide Web ou teia mundial. O conceito de web ou teia representa exatamente o que a Internet é: uma grande teia de

\footnotetext{
${ }^{55}$ Leiner, Cerf, Clark, Kahn, Kleinrock, Lynch, Postel, Roberts e Wolf História da Internet Tradução de Aisa Pereira, de "A Brief History of the Internet", escrita por Barry M. Leiner, Vinton G. Cerf, David D. Clark, Robert E. Kahn, Leonard Kleinrock, Daniel C. Lynch, Jon Postel, Larry G. Roberts e Stephen Wolff, criadores da Internet .http://www.aisa.com.br/historia.html
} 
cabos e comunicações via satélite ligando servidores e micro-computadores de todo o mundo entre si através do padrão de comunicação da Internet.

O www é exatamente a porção da Internet que nos interessa, pois ele constitui a "grande biblioteca" mundial, ou o conjunto de textos postos à disposição de qualquer internauta.

- O que é um website?

(...) Website [ou simplesmente site] é um lugar no ambiente Web da Internet que é ocupado com informações (texto, fotos, animações gráficas, sons e até vídeos) de uma entidade ou de uma pessoa. Cada website tem uma URL, que significa Uniform Resource Location, ou, traduzindo, local uniforme do recurso. Uma URL é um endereço virtual que indica exatamente onde as informações da empresa ou da pessoa se encontram e geralmente tem o formato www.nomedoprovedor.com.br/seunome ou www.dominioproprio.tipododominio.br."

(PEREIRA idem : ibidem)

\section{- O que é o hipertexto?}

O hipertexto é o padrão de texto adotado na Internet. É um documento colocado em um suporte informatizado, composto de unidades de texto de diversos gêneros, mais ou menos curtas, relacionadas entre si por ligações semânticas ou operacionais, os chamados links, e acessíveis - sempre de maneira parcial e limitada pelo tamanho da tela e pela estrutura dos links - através da ação do leitor, o qual ativa essas ligações segundo a ordem que lhe convém.

Entre as tecnologias que se difundiram a partir do fim do século XIX, como a eletricidade, o telefone, a televisão, a Internet foi a que teve a difusão mais rápida, atingindo a marca de 50 milhões de usuários em apenas quatro anos. Atualmente, 
segundo estatísticas de 2008, dos 6,6 bilhões de seres humanos, 1.463.632.361 utilizam a Internet, o que representa $21,9 \%$ das pessoas existentes ${ }^{56}$. No Brasil, a Internet tem uma expansão rápida. "Pela primeira vez mais da metade da população já teve acesso ao computador”, comemora Rogério Santanna dos Santos, em site do Comitê Gestor da Internet no Brasil. ${ }^{57}$ De maneira geral, os dados indicam que houve um forte aumento da posse e o uso das tecnologias da informação e comunicação entre os brasileiros:

\begin{tabular}{|l|l|l|l|}
\hline Posse e uso das TIC entre os brasileiros & $\mathbf{2 0 0 5}$ & $\mathbf{2 0 0 6}$ & $\mathbf{2 0 0 7}$ \\
\hline Possui computador & $17 \%$ & $20 \%$ & $24 \%$ \\
\hline Possui acesso à Internet & $13 \%$ & $14 \%$ & $17 \%$ \\
\hline Já utilizou computador & $45 \%$ & $46 \%$ & $53 \%$ \\
\hline Utilizou computador nos últimos 3 meses & $30 \%$ & $33 \%$ & $40 \%$ \\
\hline Nunca utilizou computador & $55 \%$ & $54 \%$ & $47 \%$ \\
\hline Já utilizou Internet & $32 \%$ & $33 \%$ & $41 \%$ \\
\hline Utilizou Internet nos últimos 3 meses & $24 \%$ & $28 \%$ & $34 \%$ \\
\hline Nunca utilizou Internet & $68 \%$ & $67 \%$ & $59 \%$ \\
\hline & & & \\
\hline
\end{tabular}

Tabela 1: Posse e uso das TIC entre os brasileiros. Baseada na Pesquisa TIC Domicílios e Usuários 2007.

$\mathrm{Na}$ faixa etária dos adolescentes e jovens, segundo dados de 2007, 70\% dos brasileiros de 16 a 24 anos já acessaram a Internet, 59\% de 10 a 15 anos. 60 e 53\% nas faixas etárias citadas são considerados usuários. $39 \%$ dos usuários entre 10 e 15 anos

\footnotetext{
${ }^{56}$ Internet World Stats : Usage et Population Statistics, 2008.

${ }^{57}$ Dados da pesquisa TIC domicílios e usuários 2007, do Comitê Gestor da Internet no Brasil. As tabelas

2 e 3 resumem os dados referentes a usuários de 10 a 15 e 16 a 25 anos constantes dessa pesquisa.
} 
acessam a Internet diariamente, $43 \%$ ao menos uma vez por semana; entre os usuários de 16 a 24 anos, 55\% acessam diariamente e $32 \%$ ao menos uma vez por semana. Entre 10 e 14 anos, 35\% acessam a Internet em casa, 17\% na escola e 59\% em lan houses . Entre 16 e 24 anos, $21 \%$ acessam em casa, $21 \%$ na escola e $68 \%$ em lan houses. $48 \%$ dos usuários de 10 a 15 anos utilizam a Internet entre uma e cinco horas por semana, $20 \%$ entre seis e quinze horas e $7 \%$ mais de vinte e uma horas; entre os usuários de 16 a 25 anos, $43 \%$ acessam a Internet entre uma e cinco horas e $26 \%$ entre seis e quinze horas, mas sobre a $13 \%$ o número de jovens que permanecem mais de vinte e uma horas por semana conectados.

\begin{tabular}{|l|l|l|}
\hline Usuários, local e tempo de conexão & $\mathbf{1 6}$ a 25 anos & $\mathbf{1 0}$ a 15 anos \\
\hline Já acessaram a Internet & $70 \%$ & $59 \%$ \\
\hline Usuários & $60 \%$ & $53 \%$ \\
\hline Acessam diariamente & $55 \%$ & $39 \%$ \\
\hline Uma vez por semana & $32 \%$ & $43 \%$ \\
\hline Em casa & $21 \%$ & $35 \%$ \\
\hline Na escola & $21 \%$ & $17 \%$ \\
\hline Em lan houses & $68 \%$ & $59 \%$ \\
\hline Uma a cinco horas por semana & $46 \%$ & $48 \%$ \\
\hline Seis a quinze horas por semana & $26 \%$ & $20 \%$ \\
\hline Mais de vinte e uma horas por semana & $13 \%$ & $7 \%$ \\
\hline
\end{tabular}

Tabela 2: Jovens usuários, local e tempo de conexão. Dados da Pesquisa TIC Domicílios e Usuários 2007.

Se tal é o alcance da Internet no Brasil, qual será sua influência? 
Os dados estatísticos acima mostram que, se há uma difusão intensa da Internet na sociedade brasileira, essa incide - como, aliás, no resto do mundo - muito especialmente sobre os jovens. Que novas implicações terá a educação do jovem que já conheceu o mundo sob influência da Internet? ${ }^{58}$.

O que está fazendo nosso adolescente na Internet? 90\% dos usuários de 10 a 15 anos e $92 \%$ dos 16 a 25 anos declararam conectar-se para o lazer, mais especificamente, $21 \%$ dos de 10 a 15 anos e $44 \%$ de 16 a 25 anos lêem jornais e revistas, $46 \%$ e $53 \%$ respectivamente vêem filmes ou vídeos (em sites do tipo You Tube), os jogadores on line são $64 \%$ e $47 \%$, entre 10 a 15 anos e 16 a 25 anos. Entre os que declaram usar a Internet para comunicação, estão $82 \%$ dos usuários de 10 a 15 anos e $94 \%$ dos que tem entre 16 e 25 anos. Por comunicação eles entendem 64 e $83 \%$ respectivamente a troca de e-mails, 40 e $61 \%$ o uso dos messengers e 71 e $77 \%$ a freqüência ao Orkut e similares. O uso da Internet para fins de Educação atinge 87\% entre os de 10 a 15 anos e $75 \%$ entre os jovens de 16 a 25 anos. A pesquisa escolar, entre esses, ocupa $84 \%$ dos usuários de 10 a 15 anos e $68 \%$ daqueles de 16 a 25 anos.

\begin{tabular}{|l|l|l|}
\hline Tipo de atividades & $\mathbf{1 6}$ a 25 anos & $\mathbf{1 0}$ a 15 anos \\
\hline Lazer & $92 \%$ & $90 \%$ \\
\hline Leitura de jornais e revistas & $44 \%$ & $21 \%$ \\
\hline Filmes e vídeos (You Tube) & $53 \%$ & $46 \%$ \\
\hline Jogos (on line e down load) & $47 \%$ & $64 \%$ \\
\hline Comunicação & $94 \%$ & $82 \%$ \\
\hline Troca de e-mails & $83 \%$ & $63 \%$ \\
\hline
\end{tabular}

\footnotetext{
${ }^{58}$ Emblemática dessa ligação entre Internet e a existência do mundo é a resposta de uma aluna de 13 anos à minha questão:

- "Vocês sabem quando surgiu a Internet?"

-"Professora, a Internet sempre existiu!"
} 


\begin{tabular}{|l|l|l|}
\hline Mensagens instantâneas & $61 \%$ & $40 \%$ \\
\hline Sites de relacionamento (tipo Orkut) & $77 \%$ & $71 \%$ \\
\hline Educação & $75 \%$ & $87 \%$ \\
\hline Pesquisa escolar & $68 \%$ & $84 \%$ \\
\hline
\end{tabular}

Tabela 3: Atividades dos jovens usuários em Internet. Dados da pesquisa TIC Domicílios e Usuários 2007 pp. 155-166.

No meio de tantas atrações diferentes, quanto tempo ocupará de fato a pesquisa escolar, entre os jovens internautas? Não muito grande, a crer na tentação a que cedem os brasileiros mais velhos no trabalho: "Brasileiro diminui tempo de 'vadiagem' na web durante trabalho, diz pesquisa: usuário gasta em média 51 minutos por dia com 'navegação pessoal',"59.

Além disso, que nível de aproveitamento terá seu trabalho escolar na Internet? Estudo da consultoria americana Nielsen Norman Group, que acompanhou a navegação de adolescentes de 13 a 17 anos nos Estados Unidos e na Austrália, mostra que adultos são mais bem sucedidos que os adolescentes na busca de informações e outras atividades complexas na Internet ${ }^{60}$ :

"eles encontram dificuldades para decifrar páginas de estrutura complexa ou baixar arquivos da rede (...) por não ter muita bagagem de leitura, a maioria dos jovens tende a se confundir diante de frases mais elaboradas e a não usar de forma competente os sistemas de busca, que são as portas para a internet (...). 'Os adultos são mais preparados para obter o que querem. Salvo raras exceções, a imagem do adolescente como um navegador exímio não resiste aos fatos', diz Jakob Nielsen, organizador da pesquisa", concluindo, "ao navegarem na internet junto com os pais, os filhos têm, sim, muito a aprender".

\footnotetext{
${ }^{59}$ Notícia do site G1 em 09/10/08. Disponível em http://g1.globo.com/Noticias/Tecnologia/0,MUL791955-6174,00BRASILEIRO+DIMINUI+TEMPO+DE+VADIAGEM+NA+WEB+DURANTE+TRABALHO+DIZ+PE SQUISA.html

${ }^{60}$ Artigo publicado em Veja (ed. 1896, 16.03.05) : "Nisso eles são bons...mas, na hora de navegar na internet, os adultos é que entendem do riscado"
} 
Igualmente o sério e corajoso estudo de Dwyer, Wainer et allii $(2007: 1)^{61}$, já citado, que usa as pesquisas do $\mathrm{SAEB}^{62}$ para verificar o desempenho de alunos de $4^{\mathrm{a}} \mathrm{e}$ $8^{\mathrm{a}}$ série do ensino fundamental e da $3^{\mathrm{a}}$ série do ensino médio e a relação deste desempenho com o uso de computador para realizar tarefas escolares, relata:

"Os resultados demonstram que para os alunos de todas as séries e para todas as classes sociais o uso intenso do computador diminui o desempenho escolar. Para alunos da $4^{a}$ série, das classes sociais mais pobres, mesmo o uso moderado do computador piora o desempenho nos exames de português e matemática. Esses resultados indicam claramente que é preciso repensar o papel do computador no ensino, sobretudo para os alunos mais pobres, para quem o uso do computador está surpreendentemente associado a uma piora nas suas notas" (destaques nossos).

Esses estudos lembram algo que muitos educadores e famílias prefeririam não saber: a necessidade de apoio e de formação para o uso da informática.

\section{O uso pedagógico da Internet (ou TICE)}

A oportunidade de uma integração das TIC em Educação suscitava, ainda em 2001, segundo artigo de Pouts-Lajus (2001: 1), vivos debates entre crentes, ateus e agnósticos das tecnologias, a respeito dos reais efeitos dessas últimas em termos de resultados pedagógicos. Em fins de 2008, no Brasil, tornado o maior consumidor mundial de Internet domiciliar (!) ${ }^{63}$, essa questão - ainda não decidida - não nos parece

\footnotetext{
${ }^{61}$ Desvendando mitos: os computadores e o desempenho no sistema escolar http://www.scielo.br/scielo.php?script=sci_arttext\&pid=S0101$73302007000400003 \& \operatorname{lng}=$ en $\&$ nrm=iso\&tlng=pt

${ }^{62}$ Sistema de Avaliação da Educação Básica (Saeb).

${ }^{63}$ Veja-se a nota anterior : "primeiros no mundo em tempo gasto na Web, de acordo com dados do Ibope//NetRatings" 24/07/2008 Notícia disponível em http://wnews.uol.com.br/site/noticias/materia.php?id_secao=1\&id_conteudo=11243
} 
suficiente para recusar a inserção das tecnologias na escola, pois, com esse mesmo autor (POUTS-LAJUS 2005 : 12), cremos que

"Logo de saída, a presença do computador [na escola] foi fundamentada em um imperativo cultural : o lugar dos computadores na cultura é tal que a educação - essa entrada na cultura, segundo a bela fórmula de Jerome Bruner - não pode mais se fazer sem a aprendizagem e o uso dessas máquinas." 64

Essa não é uma constatação sem efeitos pois são grandes os problemas levantados por uma adoção bem refletida das TICE. Entretanto, no comentário de Tardif (2002: 16),

"uma das escolhas poderia ser ignorar, mas os jovens pagariam indevidamente o preço disso. Quando se pensa que uma criança que entra na escola em 2001 sairá dela provavelmente entre 2015 ou 2020, a falta de alfabetização informática para esse jovem em meio escolar constituiria um drama" 65

Puren (2001 : 2-3) traça um quadro, um tanto irônico, dos vários tipos de discurso em relação à adoção das TIC em didática de línguas :

“voluntarista: 'É absolutamente necessário utilizá-las'; maximalista: 'É preciso que todos os professores as utilizem constante e maciçamente. '; otimista: 'Basta que elas sejam utilizadas para que o ensino e a aprendizagem sejam mais eficazes. '; messiânico: 'Sua utilização abre perspectivas ainda não imaginadas para o ensino/aprendizagem das línguas.' (...) ou, ao contrário (...) hesitante, minimalista, pessimista, e até mesmo catastrofista. (...)" ${ }^{66}$,

\footnotetext{
64 « D'emblée, la présence de l'ordinateur a été fondée sur un impératif culturel. La place des ordinateurs dans la culture est telle que l'éducation, cette entrée dans la culture selon la belle formule de Jerome Bruner, ne peut plus se faire sans l'apprentissage et l'usage de ces machines. »

${ }^{65}$ "l'un des choix pourrait être l'ignorance, mais les jeunes en paieraient indûment le prix. Quand on pense qu'un enfant qui entre à l'école en 2001 en sortira problablement entre les années 2015 et 2020, l'absence d'alphabetisation numérique pour ce jeune en milieu scolaire constituerait un drame».

66 «volontariste : 'Il faut absolument les utiliser', maximaliste : 'Il faut que tous les enseignats les utilisent contamment et massivement', optimiste: 'Il suffit qu'elles soient utilisées pour que
} 
para finalmente chegar a uma posição equilibrada a respeito da inserção das TIC, que pede certas condições e contempla certos valores que podem levar ao progresso do ensino/aprendizagem das línguas: o movimento - condição inevitável para haver progresso, embora nem todo mudança seja proveitosa - a diversidade de percursos e estilos de aprendizagem, que pode ser enriquecida pelo uso das TIC - $e$ a autonomia tanto do aprendiz quanto do professor, favorecida pela possibilidade de adoção de estratégias individuais no uso das TIC . ${ }^{67}$

\section{Voluntarista Maximalista Otimista Messiânico

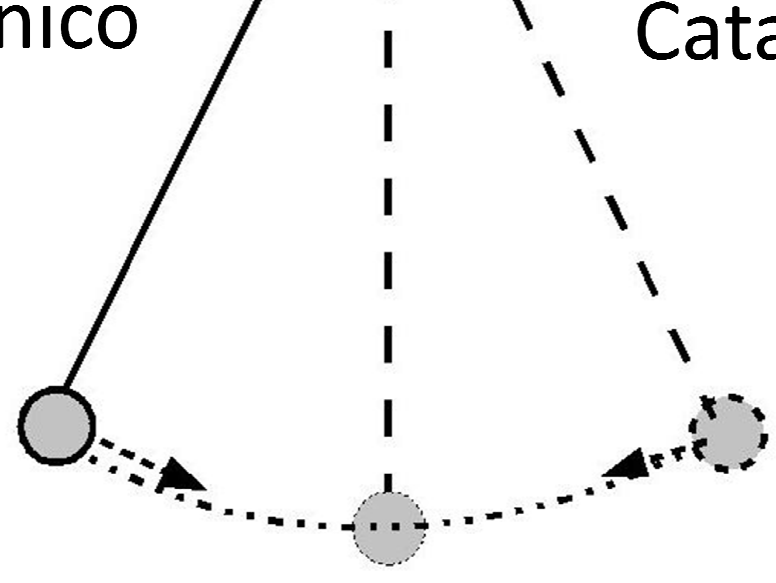 \\ Pro-TIC cum modum}

Figura 3: Discursos pró e contra as TIC em LE. Quadro baseado em Puren (2001 : 2-3).

l'enseignement et l'apprentissage soient plus efficaces ', messianique : 'Leur utilisation ouvre des perspectives encore insoupçonnées à l'enseignement/apprentissage des langues', (...) ou, à l'inverse (...) irésolu, minimaliste, pessimiste, voire catastrophiste. »

67 “le mouvement, la diversité, l'autonomie" (Idem. p.2-3). 
Se pleiteamos, portanto, a adoção das TIC - cum modum - a quem devemos pregar sua conveniência? Tardif (2002 : 16) considera que "na escola, as tecnologias tornar-se-ão uma realidade sob certas condições, cuja implementação repousa diretamente sobre os professores." ${ }^{68}$ Brodin (2002 : 152), em seu estudo sobre a realidade do emprego das TICE na escola francesa, defende a mesma opinião:

"A inovação é uma mudança desejada por aqueles que não têm o controle das regras, os próprios professores (diferindo nisso da reforma institucional). Ela repousa sobre o voluntariado (...). A inovação é uma aceitação de riscos. Ela não se desenvolve linearmente e os objetivos atingidos não são forçosamente aqueles definidos na partida (...). Citando Ellis: a inovação é essencialmente, e por tradição, uma questão 'de campo', no ensino de línguas" ${ }^{69}$.

Ora, é igualmente sobre o professor que vai repousar também a responsabilidade da coerência pedagógica. De onde a necessidade de uma intensa reflexão sobre o emprego das TICE e de uma difusão maior desse pensamento, pois, ainda com Brodin (2002 : 149):

\begin{abstract}
"essas tecnologias não têm, enquanto tais, efeitos diretos sobre a aprendizagem, mas esses efeitos são ligados às estratégias empregadas tanto da parte do aprendiz quanto do professor (...). A escolha fundamental não se situa no fato de optar por tal tecnologia mas na decisão de conceber uma seqüência ou um ambiente de
\end{abstract}

\footnotetext{
${ }^{68}$ «à l'école, les technologies deviendront une realité sous certaines conditions dont la mise en oeuvre repose directement sur les enseignants. »

${ }^{69}$ "L'innovation est un changement voulu par ceux qui n'ont pas la maîtrise des règles, les enseignants eux-mêmes (différant en cela de la réforme qui est institutionnelle). Elle repose sur le volontariat (...)L'innovation est une prise de risques. Elle ne se déroule pas linéairement et les objectifs atteints ne sont pas forcément ceux définis au départ. Ces spécificités ressortent de tous les propos des enseignants interviewés sur leur chemin parcouru et les résultats obtenus.(...) Ellis : l'innovation est essentiellement et, par tradition, une affaire de terrain dans l'enseignement des langues».
} 
aprendizagem segundo um modelo pedagógico conforme os efeitos esperados sobre o aprendiz". 70

Em relação à função que deve exercer as TIC no ensino/aprendizagem de línguas, Puren encontra na perspectiva histórica quatro "modelos": complementaridade, integração, ecletismo e autonomia. Por complementaridade entende-se o modelo que põe nas mãos do professor "um novo instrumento", do qual esse tirará o partido que se adaptar a sua prática pedagógica pré-existente. O modelo de integração constitui a adoção da tecnologia no próprio cerne da metodologia, como foi o caso da metodologia áudio-visual. No modelo de ecletismo, não há uma preocupação em criar uma nova metodologia global, mas são descritos a priori as possibilidades, ou a posteriori os efeitos, de procedimentos variados de uso das TIC para o ensino das línguas. Finalmente, o modelo de autonomia é aquele utilizado em "centros de recursos" - locais em que o aluno dispõe de material didático e orientação individual para seguir seu próprio percurso de aprendizagem - o que faz com que o aluno possa passar de um modelo a outro, servindo-se dos recursos disponíveis.

\begin{tabular}{|l|l|l|}
\hline MODELOS & $\begin{array}{l}\text { ESTATUTO DA } \\
\text { TECNOLOGIA }\end{array}$ & PROJETO PEDAGÓGICO \\
\hline COMPLEMENTARIDADE & Dependente & $\begin{array}{l}\text { As novas tecnologias são } \\
\text { mobilizadas separadamente e } \\
\text { ocasionalmente pelo professor a } \\
\text { serviço de uma coerência global de } \\
\text { ensino pré-existente }\end{array}$ \\
\hline INTEGRAÇÃO & $\begin{array}{l}\text { As novas tecnologias são } \\
\text { mobilizadas conjuntamente e } \\
\text { sistematicamente juntamente com } \\
\text { outros elementos), pelos criadores de }\end{array}$ \\
\hline
\end{tabular}

\footnotetext{
70 « ces technologies n'ont pas, en tant que telles d'effets directs sur l'apprentissage mais ces effets sont liés aux stratégies mises en oeuvre aussi bien de la part de l'apprenant que de l'enseignant. (...) Le choix fondamental ne se situe pas dans le fait d'opter pour telle technologie mais bien dans la décision de concevoir une séquence ou un environnement d'apprentissage selon un modèle pédagogique conforme aux effets attendus sur l'apprenant»
} 


\begin{tabular}{|l|l|l|}
\hline & & $\begin{array}{l}\text { metodologias, para construir uma } \\
\text { nova coerência global de ensino }\end{array}$ \\
\hline ECLETISMO & $\begin{array}{l}\text { As novas tecnologias são tomadas } \\
\text { separadamente e sistematicamente } \\
\text { para, através do exame de suas } \\
\text { potencialidades, propô-las ao as } \\
\text { professor, e de seus efeitos sobre os } \\
\text { aprendizes, descrevê-las, em novas } \\
\text { coerências parciais de } \\
\text { ensino/aprendizagem. }\end{array}$ \\
\hline AUTONOMIA & $\begin{array}{l}\text { As novas tecnologias são } \\
\text { mobilizadas separada ou } \\
\text { conjuntamente, ocasional ou } \\
\text { sistematicamente pelo aprendiz em } \\
\text { centro de recursos, para construir, } \\
\text { por si mesmos, coerências variadas } \\
\text { de aprendizagem. }\end{array}$ \\
\hline
\end{tabular}

Tabela 4: Modelos de inserção das novas tecnologias no ensino/aprendizagem das LE. Quadro resumido de PUREN (2001 : 11).

Nos modelos que nos interessam, que são o de complementaridade e o ecletismo - visto não estarmos nem em contexto de uma metodologia previamente articulada incluindo as TIC, nem em contexto de autonomia, como existente na escola francesa - a iniciativa de adoção da inovação tecnológica será, como mostramos, normalmente do professor.

\section{Conclusão do Capítulo II}

O uso da Internet se impõe à escola, pela pressão da sociedade, da família e do aluno.

Gostaríamos que este estudo lhe pudesse ser proveitoso. 


\section{Capítulo III - Leitura em Internet}

Quando se fala de leitura em Internet, uma série de aspectos pode ser levada em conta. Em primeiro lugar, há o "objeto" a ser lido, que pode ser estudado em relação ao suporte informatizado - que compreende a tela, o teclado etc., os quais têm certamente influência sobre o ato de ler - em relação ao conteúdo do texto da Internet, e ainda em relação ao modo de organização textual dominante - que é o hipertexto. Em seguida, há o leitor, com suas capacidades e objetivos de leitura. Finalmente, devem ser estudadas as formas de leitura que decorrem desse encontro entre o texto e o leitor ${ }^{71}$.

\section{O objeto da leitura}

\section{a. $O$ suporte: o texto informatizado}

Um texto, segundo Lévy (1995 : 33), é sempre uma entidade virtual ou abstrata, no sentido de que não se confunde com o suporte no qual se apresenta, podendo existir igualmente em uma multiplicidade de cópias, versões, traduções e edições. A relação entre o texto e o suporte que o traz pode ser analisada de diversos pontos de vista. A evolução histórica dos suportes obedeceu a uma busca de melhor conservação e facilidade de acesso aos textos neles contidos. Assim, o texto oral existe desde o aparecimento da humanidade. Conversacional, mas também poético e épico, o texto oral se conservava no primeiro suporte existente, que é a própria memória. $\mathrm{O}$ surgimento da

\footnotetext{
${ }^{71}$ Esse esquema de análise é o adotado por Bertrand-Gastaldy (2002).
} 
escrita significou uma conservação muito superior, no sentido da amplitude de dados armazenados, na variedade de tempos e espaços alcançados pela informação. Tal ampliação continuou durante os milênios de progresso da escrita, com a invenção do papiro, do in-folio, do papel, da imprensa e finalmente da informática, num continuum. Do mesmo modo, o acesso à informação cresceu com a difusão do livro durante a Idade Média, sua impressão no Renascimento, e sua informatização no presente, disponibilizando, ao mesmo tempo, uma grande massa de informações a um grande número de usuários.

No quadro abaixo listamos algumas características do texto informatizado, em comparação com o texto no suporte papel.

\begin{tabular}{|c|c|}
\hline TEXTO EM PAPEL & TEXTO EM TELA \\
\hline Texto : entidade abstrata & Texto abstrato \\
\hline Suporte material : papel (?) impresso & Suporte material : arquivo \\
\hline Objeto único & $\begin{array}{l}\text { Arquivo pode ser lido em qualquer } \\
\text { computador }\end{array}$ \\
\hline Espaço delimitado com começo e fim & Espaço de leitura sem começo e fim \\
\hline Portátil, manejável, autônomo & Dependente do computador \\
\hline Folheável & Clicável \\
\hline Páginas de mesmo tamanho, numeradas & $\begin{array}{l}\text { Páginas de tamanho variável, móvel, } \\
\text { raramente numeradas }\end{array}$ \\
\hline $\begin{array}{l}\text { Scripta manet : o texto permanece } \\
\text { enquanto durar o suporte }\end{array}$ & $\begin{array}{l}\text { Aparece ou desaparece por iniciativa do } \\
\text { leitor: o suporte guarda dados ilegíveis. }\end{array}$ \\
\hline Não pode ser alterado sem deixar traços & Pode ser alterado, truncado, acrescentado \\
\hline
\end{tabular}




\begin{tabular}{|l|l|}
\hline Mantém as características visuais originais & $\begin{array}{l}\text { Pode ter alterados: tamanho, fontes, } \\
\text { cores... }\end{array}$ \\
\hline Negrito e sublinhado põem em destaque & Negrito e sublinhado escondem outro \\
texto \\
\hline Se informatizado parece pobre & Se impresso perde luz, movimento e links \\
\hline Permite ler em muitas posições & Exige manter sempre a mesma postura \\
\hline Indice, capítulos & Menu, páginas \\
\hline Imagem fixa & Imagem fixa ou móvel, som \\
\hline
\end{tabular}

Tabela 5 : Características do texto em papel e em suporte informatizado. Quadro baseado em de Serres (2004 :135) ; Bertrand-Gastaldy (2002 : 3, 8) ; Potolia e Mochet (2002 : 30)

\section{b. A grande biblioteca : Internet}

A Internet representaria, de fato, uma volta da leitura e da escrita, numa sociedade que parecia querer abandonar a escrita em favor da imagem? Teria algo a dizer o individualista solitário, suposto personagem-tipo da sociedade dita pósmoderna? Virilio (1999 : 73 ) supõe que não:

"A aceleração tecnológica operou, em primeiro lugar, a transferência da escrita para a palavra falada - da carta e do livro para o telefone e o rádio... - e hoje é a palavra (o verbo) que logicamente perece diante da instantaneidade da imagem em tempo real. Com o iletrismo e o analfabetismo, delineia-se a época dos micros silenciosos, do telefone mudo, não mais em pane técnica, mas em pane de sociabilidade, porque logo não teremos mais nada a nos dizer, nem realmente tempo de dizer - pois antes de tudo, não saberemos mais como fazer para escutar ou dizer alguma coisa, assim como já não sabemos bem o que escrever, apesar da revolução do fax, que deveria, por assim dizer, reativar a atividade epistolar". 
Entretanto, o computador ainda é, certamente, na expressão de Eco (1996 : 4) um “instrumento alfabético”:

\begin{abstract}
"Nos anos 60, Marshall McLuhan escreveu sua A Galáxia de Gutenberg, onde anunciava que a maneira linear de pensar instaurada pela invenção da imprensa estava para ser substituída por uma forma mais global de percepção e compreensão através de imagens de TV ou outros tipos de dispositivos eletrônicos.[...] Certamente um computador é um instrumento por meio do qual pode-se produzir e editar imagens, certamente instruções são supridas por meio de ícones; porém, é igualmente certo que o computador vem a ser, antes de tudo, um instrumento alfabético. Em sua tela rolam palavras, linhas e, para usar um computador, você deve ser capaz de escrever e ler. [...] Pessoas que passam a noite implementando intermináveis conversações pela Internet estão, principalmente, trabalhando com palavras. Se a TV pode ser considerada como um tipo de janela ideal através da qual vê-se o mundo todo sob a forma de imagens, a tela do computador é um livro ideal no qual se lê sobre o mundo na forma de palavras e páginas".
\end{abstract}

O maior benefício da Internet parece ser o do acesso de qualquer internauta à mais formidável biblioteca já imaginada. No dizer de Michel Serres (1997 : 1),

\begin{abstract}
"A novidade é a desaparição da concentração do saber. Até aqui, toda a empresa de formação consistia, para cada um de nós, em ultrapassar, não uma, mas várias distâncias, entre seu lugar de nascimento, de partida, e o local em que se encontravam concentrados os elementos do saber: bibliotecas, universidades, laboratórios, museus de história natural (...). E a pedagogia de outrora era todo o percurso do combatente para chegar às fontes do saber. (...) A novidade de nosso mundo é que a pessoa humana não se desloca mais, mas o próprio saber chega à pessoa por meio dessas redes de comunicação" ${ }^{, 72}$
\end{abstract}

\footnotetext{
${ }^{72}$ «La nouveauté, c'est la disparition de la concentration du savoir. Jusqu'ici, toute l'entreprise de formation consistait pour chacun d'entre nous à franchir, non pas une, mais plusieurs distances, entre son lieu de naissance, de départ, et l'endroit où se trouvaient concentrés les éléments du savoir: bibliothèques, universités, laboratoires, muséums d'histoire naturelle. (...). Et la pédagogie de jadis était
} 
A Internet traz uma espécie de "revolução coperniciana"73 na leitura. Na biblioteca, o leitor girava em torno das estantes e dos livros. No "ciberespaço" dá-se o inverso: o leitor está imóvel e os textos vêem até ele.

Entretanto, há na Internet do melhor e do pior, estudos e textos excelentes e muito lixo $^{74}$ (Eco 2000 : 2) tudo em proporções colossais. Os riscos são enormes, como lembra Siqueira $(2008)^{75}$

"É bom lembrar que, por mais benefícios que a internet nos possa trazer, quase metade de seu conteúdo é lixo da pior qualidade, que inclui pedofilia, armadilhas criminosas, propaganda nazista, instruções de como cometer suicídio (com conseqüências trágicas para vários jovens), violência e tentativas de fraude e furto de identidade, assédio e exposição a conteúdo sexual, venda e distribuição de drogas - além da disseminação de vírus e softwares espiões que invadem nossos computadores, furtam nossa identidade e transmitem a terceiros nossos dados pessoais, números de contas e senhas".

E o próprio excesso tem seus efeitos, segundo o mesmo Eco: “Uma boa quantidade de informação é benéfica e o excesso pode ser péssimo, porque não se consegue encará-lo e escolher o que presta". "Se não tudo, ao menos um pouco de tudo”, diz Lévy. Um trilhão de páginas disponíveis para qualquer usuário ${ }^{76}$. A Web é uma biblioteca tão grande que se poderiam passar dias, meses e anos sem sair do

tout le parcours du combattant pour parvenir aux sources du savoir. (...) La nouveauté de notre monde est que la personne humaine ne se déplace plus, mais le savoir lui-même arrive à la personne au moyen de ces réseaux de communication."

${ }^{73}$ O termo é devido a Lévy (1997 : 68).

74 “Existem muitos sites interessantes, mas há também muito lixo"

${ }^{75}$ SIQUEIRA E. Não abandone seu filho diante da internet Artigo publicado em O Estado de São Paulo em 23.11.08. Disponível em http://www.ethevaldo.com.br/Generic.aspx?pid=386

76 “O Google anunciou que estes dias seus robots (Googlebot) contaram o número de páginas na internet em 1 trilhão de páginas na web” Notícia publicada em $29.07 .08 \mathrm{em}$ http://blog.seomarketing.com.br/2008/07/numero-de-paginas-na-internet-voce-sabe.html 
começo de sua exploração. Se nos ativermos, entretanto, à metáfora de uma biblioteca, quem poderia temer o tamanho excessivo de uma biblioteca? Se ela tem indexadores, há nela uma certa ordem... que é preciso, no entanto, conhecer.

\section{c. Hipertexto, o texto da Internet}

O hipertexto, como vimos, é composto de unidades de texto de diversos gêneros, mais ou menos curtas, relacionadas entre si por ligações semânticas ou operacionais, os chamados links, e acessíveis - sempre de maneira parcial e limitada pelo tamanho da tela e pela estrutura dos links - através da ação do leitor, o qual ativa essas ligações segundo a ordem que lhe convém. Algumas características podem ser acrescentadas a essa definição: a virtualidade, que faz com que as diversas partes de um hipertexto devam ser ativadas sucessivamente por um utilizador, para se tornarem visíveis, o que resulta em que o conjunto de um documento nunca seja acessível inteiramente ao mesmo tempo; a modularidade, porque um hipertexto é composto de unidades de informação semântica e materialmente autônomas, constituindo o conjunto desses trechos uma rede de natureza não finita, dinâmica e provisória; a multimodalidade, já que o hipertexto, ou sua versão hipermídia, é composto de textos, imagens e sons, desdobrando-se num espaço multidimensional de leitura: janelas, movimento, zonas de texto não seqüencial, texto em primeiro e segundo plano; a interatividade, através da qual um hipertexto é indefinidamente recomponível e recomposto em função das intervenções do autor ou do leitor; a ubiqüidade produzida por sua virtualidade, já que o hipertexto não se encontra em um local definido, podendo ser partilhado, em rede, por um número indefinido de pessoas, que tanto podem lê-lo, quanto escrevê-lo de forma colaborativa; e finalmente a não linearidade, pois a leitura dos diversos módulos 
independentes do texto pode ser feita na ordem que convier ao leitor, dependendo de sua escolha, ou da maneira como ele entrou no site.

Marcuschi (2000, p.10-11) afirma que tanto o texto quanto o hipertexto são “emergentes, incompletos, maleáveis, não-determinísticos, multidimensionais, multifocais, interativos”. Porém, enquanto essas características dependiam, no texto, de uma análise lingüística sofisticada para serem demonstradas, elas são evidentes e reconhecidas por todos no hipertexto. Curiosamente, Potolia e Mochet (2002 : 31) relatam estudos ${ }^{77}$ que apontam características típicas do hipertexto aparecendo também no texto escrito de imprensa (Le Figaro, Libération, Le Monde), na área de divulgação científica:

“- ataque dos textos in media res,

- fuga de uma apresentação cronológica linear e de uma narração padrão homogênea,

- aspecto fragmentado dado ao discurso indireto,

- organização espacial (...) que sugere 'ler' as ilustrações ao mesmo tempo em que os textos,

- função particular da imagem substituindo certas articulações textuais,

- recurso a micro-gêneros redacionais (cronologias, definições de termos, séries de questões-respostas, relato de ficção científica)." 78

\footnotetext{
77 (BEACCO 1992 e 1999; BLONDEL 2000)

78 - « attaque des textes in media res

- éviter une présentation chronologique linéaire et un récit standard et homogène

- allure décousue donnée aux propos rapportés

- organisation spatiale [...] qui cherche à suggérer au lecteur de 'lire' les illustrations en même temps que le texte

- fonction particulière de l'image remplaçant 'certaines des articulations textuelles'

- recours à des 'micro-genres rédactionels' ('chronologies, définitions de termes, séries de questionsréponses, récit de science-fiction etc') ou 'régimes discursifs' ».
} 
Texto e hipertexto não são, portanto, tão distantes e nem toda especificidade do hipertexto vem de seu suporte informatizado.

O mecanismo específico do hipertexto consiste em ligações entre um número indefinido de textos através da associação de palavras-chave, de uma forma que seria semelhante à atividade da memória. A intenção de copiar a memória humana levou os criadores do hipertexto a estabelecer pontos em comum com as técnicas que foram usadas historicamente para a preservação ou extensão da memória. Claeyssen (1994), analisando esse objetivo conforme foi concretizado no hipertexto, expõe através de um texto de Cícero, o princípio das "ars memorativa". Esta arte consiste em um conjunto de técnicas, usadas em uma época em que o papel e o pergaminho eram raros e caros, que forneciam os meios ao estudioso de forjar para si uma verdadeira "memória artificial", baseada numa maneira particular de organizar suas lembranças. O chamado "método dos lugares e das imagens" pedia que se representasse mentalmente um edifício - um palácio, por exemplo - e que se colocasse, em cada uma das salas desse edifício imaginário, porções daquilo que se queria lembrar. Posteriormente, a "visita virtual" ao palácio permitiria a atualização progressiva do conteúdo da memória, sendo que a própria ordem das imagens servia como índice do texto memorizado. A metáfora representava, ao mesmo tempo, uma economia de memória - na medida em que o edifício representado já era conhecido e a ele se associavam lembranças novas - uma fixidez e coesão estrutural ao conteúdo - associado à estabilidade do edifício - e finalmente a possibilidade de estabelecer relações lógicas de diversos tipos entre os trechos - graças à estrutura tridimensional do edifício, pois como já afirmava Aristóteles, a ligação entre uma imagem e sua vizinha deve ser de natureza metafórica ou metonímica ou antitética. A versão hipertextual dessa arte mostra as seguintes 
características: primeiramente, o uso das metáforas espaciais, extremamente freqüentes no hipertexto, para criar um universo de referência, evitando a sensação de "lost in cyberspace $^{79}$. Em seguida, nota-se a mesma preocupação em estabelecer liames de diversos tipos para produzir coesão e ordem entre os conceitos. Finalmente, num raciocínio simétrico, a "ars memorativa" buscava copiar interiormente uma realidade presente no mundo físico para expansão de sua própria memória; os teóricos do hipertexto, por sua vez, buscam modelar, na máquina, um modelo da memória humana. Em outras palavras, os antigos produziam um "espelho do mundo" para uso mental; os modernos produzem com o computador um "espelho do espírito", o qual, aliás, foi chamado desde o princípio de "cérebro eletrônico".

Alguns efeitos negativos decorrentes da estrutura do hipertexto são apontados pela bibliografia. O primeiro deles é o chamado lost in cyberspace, ou "perdido no espaço", efeito causado pela não-linearidade de leitura. Não tendo o hipertexto indícios do tipo numeração de páginas, capítulos etc., é difícil a localização do leitor em relação ao tamanho do texto e à pertinência do que já foi consultado. Além disso, ao permitir acessar apenas uma ou outra parte do texto ou, ainda, sair do documento original, "navegando" através dos links, de uma página a outra, de um assunto a outro correlato o hipertexto produz freqüentemente uma sensação de perda, de desorientação diante de uma grande quantidade de informações, na qual não se sabe sequer qual era a pergunta inicial. Marcuschi (2000 : 7) afirma:

“o hipertexto não tem um centro, ou seja, não tem um vetor que o determine; serve-lhe de metáfora a noção de estrela que não forma um centro, mas vários vértices que se ligam a outros vértices. [...] metáforas comuns para designar essa falta de centro do

\footnotetext{
${ }^{79}$ Noção explicada no próximo item: Efeitos negativos do hipertexto.
} 
hipertexto são as noções de labirinto, rede, tentáculo, paisagem, tecido e outros nessa mesma linha” (p.7).

Por conta dessas características, Develotte (1997, retomado em 2007 : 24) aponta no hipertexto o desaparecimento de uma série de marcas que facilitavam a "ancoragem" do texto, o estabelecimento do "local" social de seu autor e a apreensão da própria estrutura lógica do texto e do gênero textual, gerando dificuldades para a “construção do saber" através dele: heterogeneidade "homogeneizada", pela ocultação das fontes pela ausência de notas e referências ${ }^{80}$; "des-hierarquização" do texto, tendo as partes do discurso o mesmo nível: introdução, conteúdo informativo, jogo, avaliação, "sair" ${ }^{81}$; "mestiçagem" de registros de língua e tipos de discurso: justaposição de monólogo do "tutor", seqüências narrativas, descritivas, argumentativas, "paratexto",82, descontinuidade lógica, pois a relação entre as informações não é clara, devido à ausência de conectores entre as partes do hipertexto; "fuga para frente" do sentido: a curiosidade estimulada pelo hipertexto provoca baixa atenção ao texto presente e uma ânsia de prosseguir sempre; aprendizado "en passant" com baixa retenção das informações na memória.

A menção aos efeitos duvidosos do sistema hipertextual sobre a memória aparece também em outros autores. Umberto Eco $(1996: 1)^{83}$ começa sua conferência

\footnotetext{
80 "L'hétérogénéité des sources auxquelles s'alimente l'auteur du cédérom est homogénéisée par son discours qui ne laisse trace des emprunts et des modes d'intégration qu'il effectue du savoir extérieur » ${ }^{81}$ «Sur cet écran d'accueil, différents documents (livres, cahiers, feuilles de papier...) étaient présentés sans qu'aucune hiérarchie ne soit indiquée de façon à favoriser un ordre possible de consultation. De plus, ces différents documents n'étaient pas isotopiques : ils renvoyaient aussi bien à une forme( "Introduction") qu'à un contenu informatif ("Découvertes paléontologiques"), à un jeu ("Une mission archéologique") à une évaluation ("Testez vos connaissances") ou encore à une action ("Quitter") 》. 82 «le discours de vulgarisation scientifique (...) se trouvait reconfiguré dans un métissage des registres de langues particulier».

${ }^{83}$ Essa história é citada por vários autores, talvez Umberto Eco tenha sido o primeiro.
} 
De Internet a Gutemberg, com uma história, contada por Platão: o deus Thot, o inventor da escrita, ao apresentar sua invenção ao Faraó Thamus ouviu deste:

"Meu hábil Theut, disse, a memória é o maior dom que precisa ser mantido vivo via treinamento contínuo. Com sua invenção as pessoas não mais serão obrigadas a treinar a memória. Lembrar-se-ão não por esforço interno, mas por virtude de um dispositivo externo."

De fato, a evolução dessa tecnologia - a escrita - permitiu que um acúmulo de obras do pensamento, conservadas pela escrita, fosse objeto de uma memorização cada vez mais seletiva. Essa memória seletiva foi potencializada pela Internet, comenta Vandendorpe (2001 : 150) permitindo um grande aumento dos dados de que nós tomamos conhecimento sem termos, no entanto, a preocupação de memorizá-los:

"Ao sonho antigo de tudo conservar na memória (...) sucedeu o de poder tudo esquecer (...) porque a informação precisa estará sempre disponível e fácil de encontrar integralmente, quando dela tivermos necessidade ${ }^{84}$,

Qual será o efeito desse fato na aprendizagem, a qual consiste, por definição, na incorporação dos dados percebidos e compreendidos na rede de conhecimentos de que cada um dispõe?

\footnotetext{
84 “Au rêve ancien de tout retenir en mémoire, (...), a succédé celui de pouvoir tout oublier (...) parce que l'information précise restera toujours disponible et facile à retrouver dans son intégralité le jour où on en aurait besoin".
} 


\section{Leitor: o internauta}

Citando novamente Eco (2002 : 3), "Para uma pessoa mais jovem, a internet pode ser uma floresta: se você decidir virar para a esquerda em vez de ir para a direita, talvez deixe de achar o tesouro que está buscando". O que falta ao aluno para "encontrar o tesouro"? Vários autores listam os conhecimentos, habilidades e capacidades necessárias ao trabalho em Internet. Bertrand-Gastaldy (2002: 8) apresenta as seguintes, "em vários registros":

habilidades na manipulação das ferramentas informáticas, distinção entra os diferentes sistemas de signos sobre a tela (língua das mensagens diferente da língua dos comandos), domínio dos padrões de leitura das diferentes mídias, em particular da icônica, domínio da interação dos códigos semióticos, conhecimento das fontes de difusão, capacidade de avaliação crítica das fontes, aprendizagem da meta-leitura, insegurança em um universo em movimento perpétuo (?), rapidez de decodificação dos novos gêneros, aptidão para a auto-aprendizagem, capacidade de orientação, crescimento das capacidades memoriais ${ }^{85}$.

Tardif (2002 : 18) considera que “a civilização da informatização pediria (...) novos 'progressos do espírito",, 86 , entre os quais:

"a capacidade de determinar a validade das fontes documentais de todo tipo; a capacidade de analisar em profundidade a informação veiculada não somente pela escrita, mas também pela imagem e som; a capacidade de triangular diversas fontes

\footnotetext{
${ }^{85}$ « habiletés dans la manipulation des outils informatiques, distinction des différents systèmes de signes sur l'écran (langue des messages distincte du langage de commandes), maîtrise des grilles de lecture des différents médias, en particulier de l'iconique, maîtrise de l'interaction des codes sémiotiques, connaissance des sources de diffusion, capacité d'évaluation critique des sources, apprentissage de la métalecture, de l'insécurité dans un univers en mouvance perpétuelle, rapidité de décodage des nouveaux genres, aptitudes à l'auto-apprentissage, capacité d'orientation, accroissement des capacités mémorielles ».

${ }_{86}$ "la civilisation de la numérisation requerrait donc de nouveaux 'progrès de l'esprit' »
} 
documentais e diferentes dados a fim de construir uma representação pessoal, argumentada e flexível; a capacidade de ligar e organizar dados esparsos ${ }, 77$.

\section{Não é pouco!}

Mostrando uma realidade muito diferente daquela desejada pelos teóricos com seus requisitos para o bom desempenho do internauta, os estudos de J.-F. Rouet ${ }^{88}$ mostram dificuldades de compreensão, ligadas tanto ao suporte informatizado - a leitura na tela do computador - quanto à organização hipertextual do documento:

“a leitura em tela é menos fácil e eficaz do que a leitura em papel: ela é mais lenta (...) ela dá lugar a mais erros na identificação das palavras (...) ela produz uma sensação maior de fadiga do que em papel (pp.4-5) (...) a leitura de hipertextos não leva, em si, a uma melhor compreensão dos conteúdos. (...) Para tarefas simples de leituracompreensão, os resultados até aqui são a favor dos textos impressos. (p.24)”.

No que concerne a crianças, pesa ainda o baixo nível dos conhecimentos requeridos:

"para utilizar um computador, e principalmente Internet, é preciso ser um bom, e mesmo um muito bom leitor. O aluno deve poder identificar as informações em sua tela, refletir nessas informações, escolher aquelas que são úteis (através dos 'menus' ou

\footnotetext{
87 « la capacité de déterminer la validité de sources documentaires de toute nature ; la capacité d'analyser en profondeur l'information véhiculée non seulement par l'écrit, mais aussi par l'image et le son ; la capacité de trianguler diverses sources documentaires et différentes données afin de se construire une répresentation personnelle, argumentée et flexible ; la capacité de relier et d'organiser des données éparses»

${ }^{88}$ Citamos aqui ROUET 2003: «la lecture sur écran est moins aisée et efficace que la lecture sur papier: elle est plus lente (...), elle donne lieu à plus d'erreurs dans l'identification des mots (...) elle entraîne un sentiment de fatigue plus important que sur papier. (p.4-5) la lecture de réseaux hypertextes n'est pas en soi porteuse d'une meilleure compréhension des contenus. (...) Pour des tâches simples de lecture-compréhension, les résultats sont jusqu'ici en faveur des textes imprimés.(p. 24)»
} 
sites de busca) e rejeitar as que não são. Essas operações são às vezes difíceis de realizar, mesmo para um adulto. O que dizer de uma criança?" 89

Há certo choque e um temor dos efeitos de tais exigências no desenvolvimento cognitivo do aluno. Então, devemos desistir de utilizar as TICE? No entanto, a Internet está presente na vida desta criança, não há como evitá-lo! Além disso, eles se declaram tão bem adaptados que cremos que nossos temores foram vãos...

Um estudo publicado por Roussey, Barbier e Piolat (2002) mostra, porém, alguns resultados animadores. Os autores prepararam uma tarefa de redação de texto argumentativo para alunos de 10-11 anos, oferecendo como ajudas a consulta de um banco de dados proveniente da Internet (mas apresentado em versão CD-rom), e a utilização de um bloco de notas eletrônico. O resultado da tarefa foi superior ao esperado, equiparando em certos aspectos os alunos mais fracos em leitura com os mais fortes, embora a tarefa final tenha mostrado que se mantinham em geral as deficiências na produção de textos relacionadas à idade. Em relação à pesquisa documental, $80 \%$ dos alunos declararam ter encontrado na leitura argumentos em que não pensariam sozinhos, embora $70 \%$ não tenham lido todo o material disponível. Quanto ao uso do bloco de notas, ele foi favorável, sobretudo, aos alunos mais fracos em leitura, para quem a função copiar-colar permitiu usar de mais argumentos e, ao mesmo tempo, elaborá-los de modo mais pessoal.

\footnotetext{
89 " pour utiliser un ordinateur et surtout Internet il faut être un bon, voire un très bon lecteur. L'élève doit pouvoir identifier les informations sur son écran, réflechir à ces informations, choisir celles qui sont utiles (par les 'menus ou les moteurs de recherche) et rejeter celles qui ne le sont pas. Ces operations sont parfois difficiles à realiser, même par des adultes. Qu'en est-il de l'enfant?»
} 


\section{Leituras}

\section{a. A Internet determina a leitura?}

Qual seria a forma de leitura possível, recomendável ou mesmo dominante na Internet? Embora, de maneira geral, o modo de leitura dependa muito do objetivo, certos aspectos como a "inundação" textual provocada pela Internet, além da natureza e da forma de consulta do hipertexto reforçam a leitura seletiva e não linear. Essa é a opinião de Vandendorpe (2000 : 7) :

"O recorte do texto em unidades mínimas reforça uma atitude de 'écrémage'e encoraja a selecionar na massa textual apenas os elementos que correspondem a uma necessidade de informação",90.

É a constatação também de Cobb, Greaves e Horst (2001 : 135), que não chegam entretanto à mesma solução:

"Hoje em dia, uma atividade de leitura comum e acessível aos aprendizes em Internet consiste em buscar uma informação particular passando por vários sites da Web(...) Nós podemos presumir que essa pesquisa necessitará da leitura de várias fontes antes de chegar a resultados. Entretanto, não é certo que o gênero de leitura necessário para tais atividades, a menos que sejam rigorosamente dirigidas, dêem lugar a outra coisa além de um despojamento sumário na melhor das hipóteses ou à busca de uma série de caracteres, na pior. Há talvez uma redução de tarefa inevitável para as atividades de leitura em Internet: (...)'pouco demais para ler' cedeu lugar a 'demais para ler', além de, como se poderia esperar, uma redução correspondente na qualidade da interação entre texto e aprendiz". ${ }^{91}$

\footnotetext{
90 "Le découpage du texte en unités minimales renforce une attitude d'écrémage et encourage à sélectionner dans la masse textuelle les seuls éléments qui correspondent à un besoin d'information.» 91 «Aujourd'hui, une activité de lecture courante et accessible aux apprenants sur Internet consiste à rechercher une information particulière en passant par plusieurs sites de la Toile, (...) Nous pouvons présumer que cette recherche nécessitera la lecture de plusieurs sources avant d'aboutir à des résultats. Cependant, il n'est pas certain que le genre de lecture nécessaire pour de telles activités, à moins d'être rigoureusement dirigées, donne lieu à autre chose qu'un dépouillement sommaire au mieux, ou à la
} 
Ora, de fato é forçosa uma interação mais superficial entre leitor e texto no decorrer de uma pesquisa, pois, evidentemente, não é possível uma leitura "palavra por palavra" de tudo que é consultado. Entretanto, não há necessariamente nisso uma perda, pois as diversas partes dos documentos que servirão à pesquisa serão objeto de leituras em diferentes níveis de detalhe.

\section{b. A Abordagem Global do hipertexto}

Vimos no primeiro capítulo as variadas formas que toma a leitura em LE, na descrição da Abordagem Global. Curiosamente, muitas de suas proposições se adéquam perfeitamente à leitura em Internet. A definição de documento utilizada por Vigner, já citada, aplica-se perfeitamente ao hipertexto - sobretudo ao multimídia:

"um conjunto construído de signos de naturezas diversas (icônicos, gráficos, tipográficos, lingüísticos) destinados, por sua convergência e pela unidade da apresentação material, a produzir um efeito de sentido, a transmitir um certo número de informações" $"$,

assim como a multiplicidade de gêneros textuais contemplados na Abordagem Global é integrante do hipertexto: verbetes de dicionários, textos literários, textos de imprensa, catálogos, formulários, cartazes, avisos, textos de publicidade e outros, podendo mesmo

recherche d'une chaîne de caractères au pire. Il y a peut-être une réduction de tâche inévitable pour les activités de lecture sur la Toile; «trop peu à lire» a cédé la place à «trop à lire», en plus, comme on pouvait s'y attendre, d'une réduction correspondante dans la qualité de l'interaction entre texte et apprenant ».

${ }^{92}$ Texto em francês no primeiro capítulo. 
conviver dentro de um mesmo hipertexto. Quanto às unidades discursivas que foram objeto de uma nova atenção nessa abordagem - "títulos/intertítulos, índices remissivos; índices das matérias/sumários, prefácios/introduções, epígrafes, gráficos (mapas, curvas, planos, quadros estatísticos, desenhos...), imagens (fotografias e legendas, desenhos metadiscursivos...)" ${ }^{\text {93 }}$ elas constituem freqüentemente, em forma de links, ou de componentes multimídia, a própria estrutura no hipertexto.

Do mesmo modo, dentre as técnicas de leitura descritas por Moirand (1979: 53) encontram-se certas funcionalidades da informática ou da Internet e certas atitudes típicas do leitor-internauta:

- sondagem: o texto que está sendo lido foi encontrado, provavelmente, por um site de busca, graças exatamente ao termo ou expressão pertinente para a informação. Do mesmo modo, dentro da página selecionada, o recurso Localizar procura automaticamente a palavra buscada.

- 'écrémage', que se poderia traduzir por seleção, corresponde igualmente a um recurso, Selecionar, que põe em destaque determinada palavra, expressão, trecho ou até mesmo o texto inteiro, para ser copiado ou ter suas características alteradas.

- varredura e sobrevôo, ambos os termos lembram o movimento rápido do leitor dentro de uma página ou de uma página para outra, em busca de um termo que lhe chame a atenção.

- exploração ou leitura intensiva, certamente a menos praticada em Internet, embora inteiramente possível quando o objetivo de leitura o solicita, exatamente como preconizava a Abordagem Global.

\footnotetext{
${ }^{93}$ Vigner (1980 : 138-139).
} 
As etapas indicadas para uma atividade de leitura (Moirand 1979 : 24) são bastante pertinentes também para a leitura em Internet :

- atenção aos "signos icônicos - fotos, desenhos, títulos, efeitos tipográficos" aspecto fundamental do hipertexto.

- "reconhecimento das palavras-chave": esse recurso é de tal importância na Internet que, provavelmente, o aluno terá chegado ao texto por meio dele, ou seja, as palavras-chave precedem o texto.

- "busca da arquitetura do texto": a estrutura do hipertexto é - ou deveria ser baseada nessa arquitetura do texto.

Finalmente, a conclusão do processo proposto apresenta um esquema interessante para descrever o trabalho de leitura-pesquisa em Internet : a partir de um "projeto de leitura inicial", ele pode se ater a "uma apreensão global" ou "efetuar sobre certas passagens do texto uma leitura mais fina, mais detalhada, mais linear e, por que não?, uma tradução ${ }^{94,}$

\section{c. A diversificação das leituras}

Os votos da Abordagem Global parecem realizados com a leitura em Internet. Apesar da exaltação da novidade das características próprias à típica leitura hipertextual, o que se vê, na realidade, é uma grande diversificação dos modos de leitura. Inicialmente, na análise de Bertrand-Gastaldy (2002 : 8), o sistema hipertextual condiciona a primeira abordagem do texto de Internet, gerando:

\footnotetext{
94 Tradução no primeiro capítulo.
} 
"leituras fragmentadas de passagens de documentos respondendo a questões muito precisas, até mesmo factuais, que não seguem a linearidade do enunciado, mas os hiperlinks existentes ou criados pelo instrumento de pesquisa, pelo índice, em função dos objetivos do utilizador". ${ }^{95}$

Nesse momento são pertinentes as denominações "leitura de descoberta, sobrevôo, leitura seletiva" ${ }^{, 96}$. Entretanto, de outro lado encontramos

“as leituras aprofundadas, polifônicas, multidimensionais, levando à reescrita e dirigindo-se a um público de eruditos (...)” pois “a edição digital muda certamente os hábitos de leituras profissionais. Inicialmente, ela põe muito mais textos à disposição dos pesquisadores. Ela permite escrever textos mais informados, mais atualizados. Ela permite confrontar sua apreciação àquela dos outros, comparar as fontes entre elas, sob muitos pontos de vista" 97

Essa nova leitura científica, na análise de Chartier (apud Develotte 2007 : 20), mostra uma funcionalidade que ultrapassa o processo clássico de acumulação e validação do saber:

«Estes três dispositivos clássicos da prova (a nota, a referência e a citação) encontram-se profundamente modificados no mundo da textualidade digital, a partir do momento em que o leitor é posto em posição de poder ler por sua vez o livro lido pelo historiador e consultar ele mesmo, diretamente, os documentos analisados. $»^{98}$

\footnotetext{
${ }^{95}$ «des lectures fragmentées de passages de documents répondant à des questions très précises, voire factuelles qui ne suivent pas la linéarité de l'énoncé mais les hyperliens existants ou crées par linstrument de recherche, par l'index, en fonction des visées de l'utilisateur (...)»

${ }^{96}$ "la lecture de découverte, le survol, la lecture sélective» (idem).

${ }^{97}$ « les lectures approfondies, polyphoniques, multidimensionnelles, aboutissant à la réécriture et s'adressant à un public d'érudits (...) pois l'édition numérique change certainement les habitudes de lectures professionnelles. D'abord, elle met beaucoup plus de textes à la disposition des chercheurs. Elle permet d'écrire des textes plus informés, plus à jour. Elle permet de confronter son appreciation à celle des autres, de comparer les sources entre elles, sous plusieurs points de vue » (idem).

${ }_{98}$ "Ces trois dispositifs classiques de la preuve (la note, la référence et la citation) se trouvent profondément modifiés dans le monde de la textualité numérique à partir du moment où le lecteur est mis
} 
Há, portanto, recursos para modos e modos de leitura. A diferença está na finalidade com que se lê e na habilidade em utilizá-los.

Outra classificação possível diz respeito à maneira de se abordar uma pesquisa. O tipo de leitura chamada por Tricot (2000 : 2) navegação de superfície ou zapping termo que designa a atitude do telespectador que muda sem cessar de canal, não chegando a se interessar por nada - tem as vantagens e defeitos típicos da leitura em Internet. Trata-se de uma leitura de busca de informações em que "desce-se muito pouco na profundidade do documento, na profundidade do conteúdo. Recolhem-se algumas informações em um documento para passar a outro. "99 Tricot a descreve nos seguintes termos:

\begin{abstract}
"Observe o percurso de alguém face a um problema complexo de pesquisa de informações, em um sistema que ele conhece mal, e onde há muito conteúdo: (...) ele vai olhar um роисо o menu, vai um pouco ao conteúdo, volta ao menu, volta ao conteúdo etc. (...) Esse processo é efetivamente utilizado por todo mundo em um certo número de situações" 100
\end{abstract}

Já observamos esse processo, em um ritmo bastante rápido, em muitos alunos que fazem buscas em Internet. Tricot o descreve como um modo válido de abordagem de um assunto, embora aponte o risco de perder o fio do assunto, chegando a uma idéia

\footnotetext{
en position de pouvoir lire à son tour le livre lu par l'historien et consulter lui-même, directement, les documents analysés»

${ }^{99}$ « on descend très peu dans la profondeur du document, dans la profondeur du contenu. On va prendre quelques informations sur un document pour passer à un autre ».

100 “Regardez le parcours de quelqu'un face à un problème complexe de recherche d'information, dans un système qu'il connaît mal, et où il y a beaucoup de contenu : vous constaterez qu'il va aller voir un petit peu du menu, il va aller traiter un petit peu du contenu, revenir au menu, retourner dans le contenu, etc. (...)Cette démarche est effectivement utilisée par tout le monde dans un certain nombre de situations ».
} 
totalmente desconexa. Outra forma de pesquisar, que tem na escola francesa o nome de requête, consiste em pedir ao aluno que reflita sobre o objeto de sua pesquisa, que procure a articulação entre os termos da questão, que defina os termos a procurar, formando um esboço de projeto de pesquisa antes de lançar-se à busca. De modo abstrato, parece muito mais produtivo. Entretanto, cremos que não é vantajoso em um momento inicial da pesquisa, sobretudo ao aluno que paga o custo cognitivo de ler em LE. Concluímos, com o autor (idem : 4):

"De fato, (...) são as exigências da tarefa que tornam um comportamento - o zapping, a focalização - oportuno ou inoportuno. Um comportamento pode ser totalmente pertinente em certo contexto de tarefa e pura perda de tempo em outro". ${ }^{101}$

A relação entre profundidade e extensão da leitura foi analisada por Vandendorpe (2001 : 1 ss.), que propôs os termos leitura intensiva, extensiva e hiperextensiva, relacionando-os com a mudança histórica dos suportes. Na Antiguidade, a leitura do rolo de escrita - sempre em voz alta - seguia o tempo da voz, aparentemente lento demais, se levarmos em consideração a velocidade visual de um bom leitor moderno - 54 mil palavras por hora - a comparar com a velocidade da fala - 9 mil palavras por hora. ${ }^{102}$ Mas, por outro lado, rápido demais, se o texto a ser compreendido pede pausas para reflexão e retomadas... O texto em codex - o que nós chamamos hoje de livro - fez concorrência ao rolo a partir do século I da nossa era, antecedendo de

\footnotetext{
101 «En fait, ce que l'on peut dire, c'est que ce sont les exigences de la tâche qui rendent un comportement - le zapping, la focalisation - opportun ou inopportun. Un comportement peut tout à fait être pertinent dans un certain contexte de tâche, comme il peut être une pure perte de temps dans un autre ».

${ }^{102}$ La vitesse d'une lecture est fonction à la fois de l'unité de lecture, de l'amplitude des saccades et du nombre de fixations/déplacements de l'ail. Elle est de l'ordre de :

- 9000 mots par heure pour le lecteur lent « cela correspond à la vitesse de la parole»

- 27000 mots par heure pour le lecteur moyen

- 54000 mots par heure pour le lecteur rapide Avec la pratique, une plus grande aisance de lecture donne lieu à une compréhension élargie du texte. (DEBEUGNY 2005)
} 
pouco a introdução da leitura silenciosa ${ }^{103}$, a qual, libertando o leitor do passo cadenciado da leitura em voz alta, permitiu-lhe seguir um ritmo próprio. Sendo poucos os livros que havia, esses lidos e relidos, meditados e ruminados. É a chamada leitura intensiva, que vai ser praticada durante toda a Idade Média. A leitura extensiva vai surgir após a invenção da imprensa e a sua popularização. Seu primeiro modelo acabado é o salão do século XVII, no qual era preciso demonstrar conhecer muitas coisas, sem profundidade. A Enciclopédia, no século XVIII, dá a essa fome de conhecimento amplo um verniz científico: era preciso saber de tudo um pouco, inclusive de temas científicos. Os romances do século XIX fornecem, em grande quantidade, um alimento emocional que causa um alto grau de dependência; os jornais, na mesma época, criam a necessidade de informação - em ambos os casos, instala-se uma necessidade de ler muito. As revistas, no século $\mathrm{XX}$, acrescentam à notícia a imagem, tornando-a menos abstrata e mais superficial... Em 1992, os "direitos do leitor"104 de Daniel Pennac (incluídos em sua obra Comme um Roman), difunde esse modo de leitura "hiper" extensiva até em meio escolar. Desse modo, as práticas de leitura no fim do século XX estavam prontas para "a leitura hiperextensiva à qual convidam o suporte material do computador e o formato do hipertexto" ${ }^{105}$. Portanto, se a indução de certo modelo de leitura pode ser creditado à Internet, outros modelos permanecem possíveis. Por outro lado, nem tudo na leitura hiperextensiva é devido à Internet, foi antes a mentalidade finde-siècle $X X$ que gerou, com os mesmos princípios, a Internet e a leitura hipertextual.

\footnotetext{
${ }^{103}$ É famosa a cena das Confissões de Santo Agostinho em que ele observa Santo Ambrósio enquanto esse lê. Confissões, VI, 3, 3 .

${ }^{104}$ Disponível em http://www.lettres.net/livre/commeunroman.htm

«LES DROITS IMPRESCRITIBLES DU LECTEUR

1. Le droit de ne pas lire. 2. Le droit de sauter des pages. 3. Le droit de ne pas finir un livre. 4. Le droit de relire. 5. Le droit de lire n'importe quoi. 6. Le droit au bovarysme (maladie textuellement transmissible). 7. Le droit de lire n'importe où. 8. Le droit de grappiller. 9. Le droit de lire à haute voix. 10. Le droit de nous taire».

105 «la lecture hyperextensive à laquelle invitent le support matériel de l'ordinateur et le format de l'hypertexte » L'hypertexte et l'avenir de la mémoire.
} 


\section{Conclusão do Capítulo III}

Podemos esboçar algumas conclusões do que estudamos até agora:

1. A Internet permite o acesso a um número incomparável de informações.

2. Seu uso em Educação é motivante para os alunos.

3. Não sendo um instrumento pedagógico, a tarefa de elaborar um modo de utilização recai sobre o professor - ao menos no momento.

4. Se existem inúmeros perigos em termos de conteúdo e de práticas perniciosas em relação ao aprendizado, há também possibilidade de realizações inigualáveis.

Pedagogo era, na Antiguidade, aquele que conduzia a criança à escola e, por extensão, ao saber, ainda que ele mesmo não soubesse tudo... Por que nós, modernos pedagogos, renunciaríamos a assumir, em relação à Internet, esse papel de conduzir ao saber? 


\section{Capítulo IV - A metodologia de leitura em FLE na Internet}

Após essas considerações sobre a natureza da leitura em língua materna e língua estrangeira, sobre a Internet e sobre o papel que esta pode desempenhar na escola e na didática de línguas estrangeiras e sobre os modos de leitura derivados desse suporte, devemos estabelecer a maneira como esses conceitos podem se articular para produzir procedimentos aplicáveis em sala de aula. No presente capítulo, no entanto, mais do que uma exploração larga das metodologias possíveis, limitar-nos-emos a justificar nossas escolhas com vistas aos Projetos. Para tanto é preciso primeiramente definir com clareza os objetivos pedagógicos a serem buscados.

\section{A leitura como objetivo pedagógico em FLE}

É razoável, dentro de nosso contexto, estabelecer um procedimento pedagógico que vise o desenvolvimento de uma única habilidade, no caso, a leitura? Acreditamos que sim, por diversos motivos. As possibilidades abertas por um uso intensivo da leitura em LE são muitas, justificando uma ênfase maior, ainda que temporária, do ensino dessa habilidade em relação às habilidades orais.

Ao definir os programas de ensino de LE, os PCNs (Parâmetros Curriculares Nacionais) ${ }^{106}$ preconizam um trabalho centrado no ensino da leitura, justificando esse foco através das utilizações possíveis da língua estrangeira pelos alunos brasileiros saídos do ensino médio, seus interesses e as condições de tempo e recursos de que se dispõe. Já os PCNs dirigidos ao ensino fundamental, no capítulo LE, afirmam que:

\footnotetext{
${ }^{106}$ Os PCNs constituem uma série de documentos de caráter oficial, emanados do Ministério da Educação, destinados a orientar o planejamento pedagógico na escola brasileira.
} 
A inclusão de uma área no currículo deve ser determinada, entre outros fatores, pela função que desempenha na sociedade. No Brasil, tomando-se como exceção o caso do espanhol, (...) somente uma pequena parcela da população tem a oportunidade de usar línguas estrangeiras como instrumento de comunicação oral, dentro ou fora do país. (...) Deste modo, considerar o desenvolvimento de habilidades orais como central no ensino de Línguas Estrangeiras no Brasil não leva em conta o critério de relevância social para a sua aprendizagem. (...), o uso de uma língua estrangeira parece estar, em geral, mais vinculado à leitura técnica ou de lazer. Note-se também que os únicos exames formais em Língua Estrangeira (vestibular e admissão a cursos de pósgraduação) requerem o domínio da habilidade de leitura. Portanto, a leitura atende, por um lado, às necessidades da educação formal, e, por outro, é a habilidade que o aluno pode usar em seu contexto social imediato. (PCNLE, 1998: 20)

O capítulo referente à LE em $P C N+$, de 2002, considerando o número limitado de aulas, propõe a busca de procedimentos que preparem o aluno para as "situaçõesdesafio da vida social", lembrando que "atribuir e produzir significados" é a "meta última do ato de linguagem” ultrapassando “o teórico e o metalingüístico” (MORAIS, PCN+ : 90). Com esse objetivo, a habilidade focalizada principalmente é a leitura, por permitir a aquisição de informação e a sua busca em autonomia. O caráter de ferramenta da LE facilita sua inserção em projetos interdisciplinares e sua utilização em situações reais de uso, no caso, no processo de pesquisa em fontes escritas, em que cabe ao aluno o papel de selecionar informações pertinentes, estruturá-las e organizálas de modo apropriado e coerente, tornando-o capaz de apropriar-se do conhecimento e discernir quanto a maneiras de fazer uso dele (MORAIS,PCN+ : 91) ${ }^{107}$.

\footnotetext{
${ }^{107}$ Existe um documento mais recente na série dos PCNs, Linguagens, códigos e suas tecnologias da série Orientações curriculares para o ensino médio ; volume 1, de 2006. Entretanto, o enfoque básico desse trabalho é o conceito de letramento, que foge completamente ao nosso estudo.
} 
No Guia para o utilizador do Quadro Comum Europeu de Referência para as Línguas, Trim ${ }^{108}$, argumentando em favor do ensino plurilíngüe, menciona a vida curta da informação na sociedade atual, que inviabiliza a tradução de grande parte dos textos importantes, e, ao mesmo tempo, o crescimento da oferta de textos em língua estrangeira, através da Internet, como fatores a exigir, de modo mais premente, um aprendizado da leitura em língua estrangeira.

Certos autores, como Carton (1995 : 1) defendem uma “aprendizagem diferenciada das quatro habilidades"109 - que ele agrupa em habilidades de compreensão e habilidades de produção - por considerar que nelas

“de um lado, situações e papéis sociais a assumir, em produção e em compreensão, no escrito como no oral, são diferentes, o que leva a criar conteúdos e progressões separados. Por outro lado, limitar o que os aprendizes podem compreender àquilo que eles saberiam dizer ou escrever sozinhos, equivale a freá-los em sua progressão em compreensão, tanto no oral quanto no escrito. Do mesmo modo que a competência de um nativo, o que um aprendiz é capaz de compreender pode, e deve, ultrapassar em quantidade de material lingüístico, como em número e variedade de situações o que ele é capaz de produzir. Particularmente, os documentos propostos em vista de atividades de compreensão podem e devem ser mais ricos e mais longos que os enunciados a serem produzidos. É preciso, por isso, que a compreensão escrita, de uma lado e a compreensão oral, de outro, sejam objeto de aprendizagens específicas, com uma programação, objetivos, conteúdos, suportes, atividades e avaliação próprias ${ }^{\text {,110 }}$ (idem :6)..

\footnotetext{
${ }^{108}$ Versão francesa, sem data, p.6-7.

109 "apprentissage differencié des quatre aptitudes" A distinção entre competências e habilidades, realçada por Béacco (2007 : 78), ultrapassaria os limites do nosso estudo.

110 "D'une part, les situations, et les rôles sociaux à assumer en production et en compréhension, à l'écrit et à l'oral sont différents, ce qui conduit à mettre en place des contenus et des progressions séparées. D'autre part, limiter ce que les apprenants peuvent comprendre à ce qu'ils sauraient dire ou écrire euxmêmes revient à les freiner dans leur progression en compréhension, aussi bien à l'oral qu'à l'écrit. A l'image de la compétence d'un natif, ce que l'apprenant est capable de comprendre peut, et doit, dépasser en quantité de matériau linguistique comme en nombre et en variété de situations ce qu'il est capable de produire. En particulier, les documents proposés en vue d'activités de compréhension peuvent, et doivent, être plus longs et plus riches que les énoncés qu'il leur est demandé de produire. Il faut pour cela que la compréhension écrite d'une part, et la compréhension orale d'autre part, fassent l'objet d'apprentissages spécifiques, avec une programmation, des objectifs, des contenus, des supports, des activités et des évaluations propres».
} 
Outro fator nos leva a centrar nosso trabalho na habilidade de leitura: as condições tecnológicas. Comentando esse aspecto, Lancien, um dos grandes nomes da pedagogia TICE-FLE, lembrava em 1998 (p.104) que a idéia de um curso completo em Internet, em regime de auto-aprendizagem, esbarrava na dificuldade em obter recursos em som e vídeo. A mesma idéia é desenvolvida por Mangenot (1998 : 134), que acrescenta :

\footnotetext{
“a comunicação na Web passa, portanto, essencialmente pela escrita, o que não deixa de ter implicações didáticas. A Internet permite, entretanto, renovar freqüentemente os materiais e obter dados atualizados. "111
}

Ora, dez anos depois, a nossa dificuldade em relação à informática em ambiente escolar ainda é garantir som e vídeo de qualidade. Entretanto, os vastos recursos da Internet em textos escritos autênticos e imagens, disponíveis com facilidade nos laboratórios de qualquer escola, podem nos ser muito úteis em uma abordagem baseada em leitura. Porque não aproveitarmos?

\section{A escolha dos textos}

A escolha dos textos a serem utilizados em classe de FLE é fundamental para o sucesso da atividade de leitura. Durante todo o período em que a leitura esteve afastada do centro da pedagogia de FLE, acreditou-se que o texto a ser lido deveria conter todos

\footnotetext{
111 « la communication sur la Toile passe donc essentiellement par l'écrit, ce qui n'est pas sans implications didactiques. Internet permet cependant de renouveler fréquemment les matériaux et d'obtenir des données actualisées ».
} 
os elementos já tratados em aula, de modo a poder ser compreendido inteiramente, funcionando simplesmente como uma avaliação do aprendizado anterior. Foi a Abordagem Comunicativa, na década de 70-80 que lançou o conceito de documento autêntico, fundamental, em seguida, para a Abordagem Global de leitura. Documento autêntico em FLE, segundo a definição do Dictionnaire de Didactique du Français $^{112}$, é "toda mensagem elaborada por francófonos para francófonos para fins de comunicação real: [essa noção] designa portanto tudo o que não foi concebido para a aula" $^{\prime 13}$. Na definição de Besse (1974 apud Arévalo Benito 2003 : 611) ele

"deve ser uma amostra retirada do meio de interações que realmente aconteceram entre nativos da língua ensinada/aprendida e, portanto, ser conforme a suas práticas lingüísticas autênticas, ele deve corresponder tão precisamente quanto possível aos interesses e às preocupações dos estudantes" ${ }^{\text {"114 }}$.

O interesse da utilização do documento autêntico é a apresentação de toda a riqueza de um uso real da língua, em contraposição a textos artificialmente simplificados ou criados para o estudo. Entretanto, considera-se frequentemente que ele não se adapta com facilidade à noção de progressão no ensino, sendo também em geral difícil demais para o aprendiz iniciante. De fato, Cornaire (1991 : 70) lembra, com base em sua experiência de professora de línguas, que "os textos que são difíceis demais aborrecem os estudantes, contribuem para criar um sentimento de frustração e

\footnotetext{
112 CUQ 2003, verbete "authentique"

113 " tout message élaboré par des francophones pour des francophones à des fins de communications réele : elle désigne donc tout ce qui n'est pas conçu pour la classe ».

114 "doit être un échantillon prélévé au sein des échanges ayant réellement eu lieu entre natifs de la langue enseignée/apprise et donc être conforme à leurs pratiques langagières authentiques, il doit correspondre aussi précisement que possible aux interêts et préocupations des étudiants »
} 
conduzem freqüentemente ao fracasso."115 Evidentemente, há uma escolha possível entre todos os textos de uma língua, pois eles não são todos igualmente complexos ${ }^{116}$. De maneira geral, como lembra Mangenot (2006 : 41), "é a atividade e não o suporte que vai determinar o grau de complexidade da tarefa"117. Outra vantagem do documento autêntico é a percepção do aluno de um contato direto com a cultura francesa e de um acréscimo de conhecimento, na medida em que o texto comunica-lhe informações, não se lhe mostrando apenas um pretexto para o aprendizado linguístico.

Por outro lado, o próprio fato de utilizá-lo em sala de aula retira em parte do documento seu caráter autêntico, na medida em que ele não representa mais a situação de comunicação para a qual foi criado. $\mathrm{O}$ uso do texto com função informativa tem, igualmente, o inconveniente de um envelhecimento rápido, em relação ao conteúdo. A isso somou-se sempre, no caso de jornais, revistas e documentos do dia a dia dos países francófonos, a dificuldade e o custo para obtê-los, para professores não residentes nesses países. Ora, o trabalho de pesquisa com textos autênticos da Internet responde à maior parte dessas objeções : o texto autêntico é disponível com inteira facilidade ; ele é sempre atualizado ; é sempre possível, graças à imensa quantidade de textos, 'calibrar' a complexidade do texto a escolher; e finalmente, a situação de comunicação pode ser preservada pois, apesar da dificuldade da língua, a função informativa do texto original permanece. Em meio a uma agradável comparação «náutica », Coste (1996:45) caracteriza o uso « autêntico » ainda nos primórdios da Internet :

\footnotetext{
115 «les textes qui sont trop difficiles ennuient les étudiants, contribuent à créer un sentiment de frustration et conduisent souvent à l'échec »

${ }_{117}^{116}$ Explanaremos essa questão adiante, ao tratarmos do gênero textual.

117 "c'est l'activité, et non pas le support, qui va déterminer le degré de complexité de la tâche". Mangenot 2006
} 
"As línguas são aprendidas seja "no campo", em situação de sobrevivência e de imersão, seja por um trabalho propedêutico a seu uso efetivo. [Ora,] de um mesmo posto, sem mudar de lugar, os 'aprenautas' têm toda a facilidade de passar da simulação ou do trabalho formal à um ou outro site de informação ou de comunicação inicialmente destinados a 'nativos'”. 118

Dentro do universo do documento autêntico, entretanto, nem todos os textos são igualmente produtivos para a leitura. A experiência mostra que a leitura de textos longos é necessária para levar a uma autonomia de leitura.

"Qualquer pessoa será capaz de ultrapassar o primeiro e mais importante obstáculo de uma segunda língua se chegar a ler um livro inteiro nessa língua, pois todo livro bem escrito é um microcosmo da língua em seu conjunto" ${ }^{119}$ [o destaque é nosso].

A opinião acima, citada por Cobb, Greaves e Horst (2001 : 134), ilustra um caso interessante, que se encontra freqüentemente, embora não explique suas causas. A leitura de textos extensos é uma possibilidade metodológica prevista já na Abordagem de Leitura Global (Moirand 1979 : 35). Ela é defendida também por Courtillon (2004 : 1) ${ }^{120}$ em nome da autenticidade e da motivação. Para Cobb, Greaves e Horst (2001 :

\footnotetext{
118 «Les langues s'apprennent soit sur le tas, sur le terrain, en situation de survie et d'immersion, soit par un travail propédeutique à l'usage effectif (...),[Ora,] d'un même poste, sans changer de place, les ' apprenautes' ont tout loisir de passer de la simulation ou du travail formel à tel ou tel site d'information ou de communication d'abord destinés à des 'natifs' "

119 " toute personne était capable de franchir le premier et le plus important obstacle d'une seconde langue si elle arrivait à lire un livre entier dans cette langue, tout livre bien écrit étant un microcosme de la langue dans son ensemble »

120 "Para a compreensão, tratar-se-á de escolher os textos orais e escritos mais longos e mais interessantes para a classe. Por que um texto longo? Por que um texto muito reduzido não tem freqüentemente nos manuais nenhuma autenticidade e não permite treinar a compreensão" "Pour la compréhension, il s'agira de choisir les textes oraux et écrits les plus longs et les plus intéressants pour la classe. Pourquoi un texte assez long ? Parce qu'un texte très réduit n'a souvent dans les manuels aucune authenticité et ne permet pas de s'entraîner à la compréhension”.
} 
134), existe, de fato, uma quantidade de leitura necessária para a obtenção da competência de leitura:

"os relatórios de pesquisa mostram de maneira relativamente clara que a aquisição se competências em leitura depende da quantidade de leitura feita pelo aprendiz, seja em papel seja na tela. Essa quantidade de leitura não era de fato realizável com a abordagem das habilidades [de leitura] isoladas na qual havia 'muito pouco para ler' (Reinking \& Bridwell-Bowles, 1991),"121.

Ora, uma atividade de pesquisa na Internet apresenta ao aluno uma enorme quantidade de textos a ler, através dos quais ele buscará a informação desejada. Tal abundância, em si, não o assusta, se ele já tem um mínimo de preparo para essa atividade em língua materna. Entretanto - e essa é a contrapartida à escassez de textos comum nos métodos "globalistas" $" 122$ - a esse excesso de textos, muitos deles de um nível exageradamente difícil para o aprendiz ${ }^{123}$, este responde muito rapidamente com recursos de busca de sentido pouco vantajosos - tradução automática, localização e seleção de palavras isoladas sem compreensão de uma unidade maior de texto, como o parágrafo - gerando “uma redução correspondente na qualidade da interação entre o texto e o aprendiz" "124. Como solução de conciliação entre o uso de textos extensos e um bom uso desses textos pelo aprendiz, deve-se, acreditamos, preparar o aluno para uma leitura diferenciada, baseada em estratégias diversas - à qual, aliás, ele já está acostumado na pesquisa em língua materna - que vão de uma compreensão global a

\footnotetext{
${ }^{121}$ les comptes rendus de recherche font ressortir de façon relativement claire que l'acquisition de compétences en lecture dépend de la quantité de lecture faite par l'apprenant, que cela soit sur papier ou à l'écran. Cette quantité de lecture n'était pas vraiment réalisable avec l'approche des habiletés isolées où il y avait «trop peu à lire» (Reinking \& Bridwell-Bowles, 1991).

${ }^{122}$ De acordo com a caracterização de BÉACCO (2007: 37-53)

${ }^{123} \mathrm{Na}$ expressão de COBB, GREAVES e HORST (idem ibidem), o “ 'pouco demais para ler' foi substituído pelo 'demais para ler"” («trop peu à lire» a cédé la place à «trop à lire»).

${ }_{124}$ « d'une réduction correspondante dans la qualité de l'interaction entre texte et apprenant » (idem: ibidem)
} 
uma compreensão mediana e a uma compreensão local ${ }^{125}$. Desse modo, a maior porcentagem do texto consultado deverá ser objeto de uma leitura global e apenas a parte que contém efetivamente a informação buscada será lida integralmente.

Outro aspecto primordial a ser levado em consideração na escolha dos textos para leitura em classe de FLE é o gênero a que pertence o texto. Conceituamos os gêneros textuais, com Bakhtin, como tipos de textos relativamente estáveis em termos de conteúdo temático, estilo e construção composicional:

"Estes três elementos (conteúdo temático, estilo e construção composicional) fundemse indissoluvelmente no todo do enunciado, e todos eles são marcados pela especificidade de uma esfera de comunicação. Qualquer enunciado considerado isolado é, claro, individual, mas cada esfera de utilização da língua elabora seus tipos relativamente estáveis de enunciados, sendo isso que denominamos de gênero do discurso". (Bakhtin, 1992:279)

Essa é a preocupação expressa por Béacco (2007 : 180), para quem

"a previsibilidade dos textos a compreender constitui um elemento central para a escolha dos textos que servem de suporte ao ensino laprendizagem e às estratégias de orientação da recepção", 126

As regularidades visadas por ele

“dizem respeito à estrutura linear das formas discursivas e suas realizações lingüísticas (...) em relação a pontos fixos como a abertura e a conclusão de textos, ou

\footnotetext{
${ }^{125}$ Classificação explanada por BÉACCO (idem :189 ss.).

126 "la previsibilité des textes à comprendre constitue un élément central pour le choix des textes servant de support à l'enseignement/apprentissage et aux stratégies de guidage de la réception. »
} 
a esquemas textuais disponíveis ou solicitados [como os das revistas científicas] (...) cujos limites podem ser ou não balizados tipograficamente".

Encontra-se, além disso, nesses textos, “um núcleo lexical partilhado, porque eles se referem aos mesmos objetos de discurso" utilizando, por isso, "certos meios lingüísticos privilegiados, na medida em que excluem outros, inteiramente possíveis em outras formas de comunicação" (idem : 181) ${ }^{127}$.

Lancien (1999 : 63-65), ao analisar o uso de CDRoms para o grande público, tratando de temas diversos de vulgarização - científicos, artísticos, históricos - bem como de enciclopédias, toca de leve o problema do gênero textual conveniente para o ensino de FLE. Segundo ele, há uma série de vantagens no uso desses suportes para a aprendizagem de língua. Em primeiro lugar, esse tipo de textos leva a um processo comunicativo real, em que "a língua será um meio de acesso a diferentes tipos de universos e de informações" e não "um fim em si mesma" 128 . Trata-se, além disso, de um tipo de documentos autênticos que têm a originalidade de "casar o autêntico e o didático" ${ }^{129}$, tanto em termos de conteúdo textual, quanto em relação aos modos de consulta que eles propõem. Para Lancien (idem : 67),

\footnotetext{
127 « concernent la structure linéaire des formes discursives et leurs réalisations linguistiques (...) par rapport à des points fixes comme l'ouverture et la clotûre de textes, ou à des schémas textuels disponibles ou requis (...) dont les bornes peuvent être balisées typographiquement ou non », além de « un noyau lexical partagé parce qu'ils portent sur les mêmes objets de discours » o que resulta em « certains moyens linguistiques privilégiés, dans la mesure où ils en excluent certains autres, tout à fait possibles dans d'autres formes de communication » (idem : 181)

128 «la langue sera un moyen d'accès à differents types d'univers et d'informations » e não « une fin en soi »

${ }_{129}$ " qu'ils marient authentique et didactique »
} 
“cabe ao educador não 'pedagogizar' esses suportes, mas antes propor aos aprendizes modos de consulta e compreensão, estratégias que esses poderão reempregar quando estiverem trabalhando em semi-autonomia ou em autonomia completa" ${ }^{\prime 30}$.

Consideramos que o que Lancien afirma em relação aos CDroms educativos, pode ser aplicado aos sites do mesmo tipo, em termos de valores lingüísticos e alcance pedagógico.

Do ponto de vista da estrutura textual, o texto informativo ${ }^{131}$ é apresentado por Cornaire (1991 : 57) como de compreensão mais difícil do que o texto narrativo, devido, sobretudo à maior complexidade de sua articulação lógica. Embora essa observação seja pertinente, em muitos casos, em relação à estrutura lógica do texto ${ }^{132}$, em termos de formas lingüísticas em uso no texto informativo, ela não nos parece ter a mesma razão. Citamos em apoio de nossa opinião o artigo de Goti (1996 : 8) sobre um trabalho de ensino de leitura a jovens universitários italianos. Tratando do texto informativo de divulgação científica, ela lista uma série de características formais que recomendam o uso desses textos para aprendizes de FLE:

\footnotetext{
- “ preocupação com a clareza pedagógica (...)

- atualidade do texto (...)

- realidade cultural acessível ao aluno

- emprego de um presente atemporal

- ausência de modalidades de apreciação
}

\footnotetext{
130 « il reviendra à l'enseignant non pas de 'pédagogiser' ces supports, mais plutôt de proposer aux apprenants des démarches de consultation et de compréhension, des stratégies que ceux-ci pourront réinvestir lorsqu'ils travailleront en semi-autonomie (...) ou autonomie complète, chez eux »

131 "aquele que visa a informar e a aumentar o conhecimento humano em um campo determinado" "Il vise à informer et à accroître la connaissance humaine dans un champ determiné »

${ }^{132}$ Observação apoiada em pesquisas, segundo Cornaire (idem).
} 
- apagamento das marcas pessoais do escritor e do destinatário

- (...) redução das formas pronominais (formas simples de terceira pessoa)

- redução das formas temporais (presente do indicativo)

- predominância das frases simples

- predominância das relativas entre as frases compostas

- recurso freqüente à coordenação sintática,

- freqüência das formas passivas, infinitivas e participiais" ${ }^{, 133}$.

Além de zonas de transparência ${ }^{134}$ quanto ao léxico.

Todas essas características são comuns a textos de divulgação científica para o grande público. Nos casos em que se acrescenta uma destinação específica para o público infantil ou adolescente - divulgação científica para crianças: tal tipo de recursos não é raro na Internet de língua francesa - o texto se apresenta mais simples em termos de estrutura e articulações lógicas, mas ainda bastante rico linguisticamente para aprendizes de nível intermediário. Uma última observação deve ser feita quanto ao emprego de textos da área de História. Nestes o uso reduzido dos tempos verbais do texto científico não se repete, evidentemente, pois vários tempos do passado serão

\footnotetext{
133 « souci de clarté pédagogique, il s'adapte au faible degré de spécialisation des étudiants au niveau référentiel: $l^{\prime \prime}$ actualité" du texte, son ancrage culturel, facilitent la mise en relation des données historiques, sociologiques, économiques et juridiques avec les variabilités linguistiques(...). au niveau énonciatif: (...) l'assertion est renforcée par l'emploi systématique d'un présent a-temporel, l'absence de modalités d'appréciation et l'effacement des marques personnelles du scripteur et du destinataire.

au niveau morphosyntaxique: (...)

- la réduction des formes pronominales (formes simples de troisième personne);

- la réduction des formes temporelles (présent de l'indicatif);

- la prédominance des phrases simples;

- la prédominance des relatives parmi les phrases complexes;

- le recours fréquent à la parataxe;

- la fréquence des formes passives, infinitives et participiales ».

${ }^{134}$ Une analyse pré-pédagogique a permis de relever un certain nombre de régularités (...) et de dégager à l'intérieur de celles-ci les zones de transparence et d'opacité pour l'apprenant italophone.
} 
usados, embora também o presente histórico seja bastante comum no francês. Entretanto, embora a metodologia de FLE não preveja o ensino do passé simple, a não ser em níveis avançados, em termos de um aprendizado para simples reconhecimento e compreensão, este tempo não se revela mais difícil do que o passé composé, pelo contrário, para o falante de português.

\section{As características da leitura}

Dentre as múltiplas formas de leitura possíveis, há uma escolha condicionada pelo tipo de trabalho utilizado. Inicialmente, a metodologia de projetos que será empregada pede uma leitura com "efeitos práticos": trata-se de produzir um texto para uma apresentação pública. Esse texto não será normalmente fruto de uma redação própria, mas sobretudo de uma seleção de frases e trechos de textos encontrados. Em segundo lugar, o tempo que deverá ser consagrado à leitura não permite a exploração lingüística dos textos, o esforço deve ser concentrado unicamente na compreensão de leitura. Para isso devem ser retirados caso a caso os obstáculos, da maneira menos intrusiva possível, evitando uma interrupção excessiva do fluxo da leitura. Finalmente, embora esse procedimento não deva resultar, provavelmente, no aprendizado de um grande número de itens de vocabulário, visto que não há um trabalho intensivo nesse sentido, ele permitirá, entretanto a descoberta de uma habilidade de leitura de textos longos, desconhecida do próprio aluno, fruto do trabalho de anos de aprendizado de FLE, que virá a ser mobilizada para a ocasião. 


\section{Os projetos pedagógicos}

O termo pedagogia de projetos remete a uma linha pedagógica extremamente produtiva, cujas raízes alguns fazem remontar a Dewey ${ }^{135}$. Na impossibilidade de ir tão longe, limitamos nosso estudo aos autores que tratam dos projetos na didática de FLE. Como estudioso das metodologias de FLE, Puren (2003 : 153) defende a idéia de que

“a entrada por tarefas (...) constitui o único meio atualmente disponível para construir um modo de coerência especificamente adaptado aos meios informatizados de aprendizagem" $" 136$

De fato, diante das dificuldades de "manter o norte" na Internet aplicada à aprendizagem,

"Só (...) a consciência no aprendiz de uma tarefa a realizar, do que eles devem fazer com os documentos disponíveis, é suscetivel de lhes dar o fio condutor que vai lhes permitir buscar os documentos, selecioná-los, extrair deles a informação útil, transformá-la e retransmiti-la.,"137

\footnotetext{
${ }^{135}$ GRÉGOIRE, LAFERRIÈRE $2001: 5$.

136 "l'entrée par les tâches (...) constitue le seul moyen actuellement disponible pour construire un mode de cohérence spécifiquement adapté aux environnements numériques d'apprentissage. » $\mathrm{O}$ termo tarefa utilizado pelos autores citados constitui a unidade básica da qual os projetos seriam o desenvolvimento mais complexo.

137 «Seule en effet la conscience chez les apprenants d'une tâche à réaliser, de ce qu'ils doivent faire avec les documents disponibles, est susceptible de leur donner le fil directeur qui va leur permettre de réchercher les documents, de les sélectionner, d'en extraire l'information utile, de la transformer et de la rediffuser»
} 
Mangenot (1998 : 133), reconhece duas funcionalidades básicas na Internet para o aprendizado de línguas: a informação e a comunicação. No que diz respeito à busca de informações, ele considera essencial que esta seja guiada por tarefas.

Tardif (2002 : 21) examina igualmente a questão das condições pedagógicas exigidas pelo uso das novas tecnologias em educação. Para isso distingue, com Perkins (1996), os percursos pedagógicos minimalistas e maximalistas, mostrando que esses últimos se adéquam melhor às situações de integração das tecnologias. Os percursos minimalistas implicam em situações de aprendizagem que vão do simples ao complexo, do conhecido para o desconhecido, prevendo uma série de procedimentos que se desenvolvem organizadamente no tempo, partindo da teoria para a prática e dessa para a avaliação. Os percursos pedagógicos maximalistas partem, ao contrário, de situações de aprendizagem contextualizadas e autênticas, e em conseqüência disso, complexas. Para processar essa complexidade impõe-se a transdisciplinaridade, já que nenhuma disciplina fornece todos os dados para a compreensão de um fenômeno. É igualmente a complexidade que gera um desequilíbrio cognitivo, descrito como a situação em que o aluno não conhece previamente uma grande quantidade de dados que lhe são apresentados pela situação. Para permitir que esses dados formem certa coerência é preciso dar-lhe o tempo necessário, variável segundo o aluno. E é finalmente, dentro e não posteriormente a esse processo de "reequilibração" das aprendizagens que o aluno vai ser avaliado. São essas claramente situações que indicam o uso de "projetos multidisciplinares a partir dos quais os alunos enfrentarão tarefas complexas, durante longos períodos de tempo" ${ }^{138}$. Uma advertência, entretanto, de Tardif (idem : 24), aponta certas exigências para que os percursos pedagógicos maximalistas produzam

\footnotetext{
138 «projets multidisciplinaires à partir desquels les élèves affronteront des tâches complexes, sur de longs périodes de temps»
} 
aprendizados duráveis e significativos: "um alto grau de contextualização (...) exige por outro lado (...) intervenções destinadas à descontextualização e à organização hierárquica da aprendizagem" sem as quais esses percursos maximalistas produziriam "encontros interessantes e motivantes com o saber, dos quais restariam apenas vagas lembranças (...)."139

Os percursos pedagógicos minimalistas são instrumentos úteis, em nossa opinião, para o dia-a-dia da prática escolar, dentro de um programa de aquisição organizada e gradual de conhecimentos. Por outro lado, a necessidade de descer mais vezes da teoria à prática, a utilidade de um uso instrumental dos conhecimentos, a compressão ou expansão do tempo motivada por um projeto a executar e a aquisição maciça de informações, que podem ser propiciados nos percursos maximalistas, parecem indicar as grandes vantagens de combiná-los com o sistema tradicional. É bastante evidente também sua adequação ao uso das tecnologias que, para o bem ou para o mal, se impõe cada vez mais em educação. A observar, em apoio a isso, a advertência final de Tardif, que pede justamente essa combinação entre ensino contextualizado e descontextualizado, ao final de um projeto.

Descendo a uma definição mais detalhada da metodologia dos projetos de aprendizagem, Puren (2003 : 158) afirma :

"Em pedagogia, o projeto é um conjunto de tarefas que envolvem muito de perto um grupo de alunos, em vista da realização de um produto determinado por uma duração relativamente longa (algumas semanas, alguns meses, até mesmo um ano inteiro)(...)

\footnotetext{
139 «un haut degré de contextualisation (...) exige en retour, (...) des interventions portant sur la décontextualisation et l'organisation hiérarchique des apprentissages » sem o que eles produziriam «des rencontres intéressantes et motivantes avec des savoirs, mais il n'en résulterait que des vagues souvenirs (...) »
} 
[sendo essas tarefas ] do tipo resolução de problemas, isto é, não estritamente programável pois exige ajustes constantes da parte dos próprios atores" 140

Mangenot (2006 : 38) acrescenta outra característica, baseando-se em Bouchard (1985):

"a tarefa é uma atividade (...) interacionalmente justificada na comunidade em que ela se desenvolve" ${ }^{\prime 14}$. Segundo Ellis (2003), citado igualmente por Mangenot (idem : 39),

“esse resultado (...)” que "em geral não é de ordem lingüística (...) constitui o objetivo da tarefa para o aprendiz, a partir do qual se poderá considerar a tarefa cumprida ou não, enquanto o objetivo real, do ponto de vista do conceptor é, na maior parte das vezes, a prática de uma ou outra função ou noção lingüística ou ainda de um ou outro gênero do discurso" 142

A perspectiva acional preconizada pelo Quadro Europeu Comum de Referência para as Línguas inclui as tarefas explanadas aqui, com o nome de tarefas pedagógicas comunicativas $^{143}$, ressaltando sua ênfase no sentido, seu caráter ativo e seu resultado identificável.

Certos aspectos devem ser necessariamente definidos no planejamento de um projeto, segundo Mangenot (idem : 44). Resumimos abaixo seu comentário, que diz respeito diretamente a recursos envolvendo Internet:

\footnotetext{
${ }^{140}$ «En pédagogie, le projet est un ensemble de tâches impliquant très fortement un colectif d'élèves en vue de la réalisation d'un produit déterminé sur une durée relativement longue (quelques semaines, quelques mois, voire une année entière)(...) est de type résolutions de problèmes, c'est-à-dire qu'il n'est pas strictement programable parce qu'il exige des ajustements constants de la part des acteurs euxmêmes"..

141 "la tâche est alors une activité (...) interactionnellement justifiée dans la communauté où elle se déroule».

${ }^{142}$ « ce résultat, (...) que « la plupart du temps n'est pas d'ordre langagier (...) constitue l'objectif de la tâche pour l'apprenant, à partir duquel on pourra estimer la tâche réussie ou non, alors que l'objectif réel, du point de vue du concepteur, est la plus part du temps la pratique de telle ou telle fonction ou notion langagière ou encore de tel ou tel genre du discours ».

${ }^{143}$ Capítulo 7, parágrafo 7.1 .
} 
- Duração: de poucos minutos até vários meses. A duração mínima de uma tarefa deve levar em conta a necessidade de fazer realmente sentido para o aprendiz.

- Objetivos visados: devem ser de caráter mais geral do que aqueles propostos para as seqüências didáticas, formulados em termos de situações de comunicação e gêneros discursivos ligados a essas situações.

- Competências empregadas: definidas em termos de compreensão, produção ou interação, orais ou escritas.

- Público visado: nível, idade, necessidades específicas e condições de acesso à Internet.

- Domínio: temática e tipo de discursos.

- Tarefa aberta ou fechada, escrita ou oral: a tarefa fechada prevê respostas objetivas pré-definidas, as tarefas abertas exigem uma avaliação por parte do professor. Quanto às tarefas escritas, a Internet se mostra um suporte extremamente cômodo; já para o oral, deve-se prever a forma de participação da classe.

- Suporte filtrado ou autêntico: no caso do documento autêntico, a Internet permite a consulta do suporte em seu contexto discursivo real.

- Natureza do suporte (interatividade, multicanalidade, atualidade): Mangenot condena a "sub-utilização" da Internet que seria o uso exclusivo de textos escritos não interativos ${ }^{144}$. Por outro lado, para certos tipos de tarefas, a atualidade do suporte é uma grande vantagem.

- Relação com a vida real: ligada à autenticidade do suporte.

- Participação na tarefa: trabalho individual, em duplas ou em grupos. Critérios da avaliação a ser efetuada pelo professor e pela classe.

\footnotetext{
${ }^{144}$ Cremos ter respondido a essa objeção acima: o texto escrito é aquilo de que dispomos de fato com facilidade atualmente, no quadro da informática escolar.
} 
- Instrumentos requeridos: os computadores com a conexão e os programas adequados, como por exemplo, o PowerPoint, o datashow para a apresentação.

Outros recursos não são indispensáveis, mas favorecem o sucesso do projeto:

- Recursos de retaguarda para a realização da tarefa: entre esses recursos, encontram-se dicionários e gramáticas on-line, cujos endereços são fornecidos ao aluno, que deles faz uso quando julgar necessário.

- Necessidade de um 'plano de vôo': as diversas etapas do projeto serão cumpridas por cada aluno, ou cada grupo, em ritmos diferentes. Por isso existe a necessidade de instruções claras sobre cada fase, que permaneçam à disposição da classe durante todo o decorrer do trabalho. Esse 'plano de vôo' pode ser apresentado em uma folha xerografada; pode ser colocado em rede, se o colégio dispõe de uma; pode ser disponibilizado em um blog, que serviria também para recolher os trabalhos dos alunos; ou pode ser também enviado por e-mail, sendo também recebidos por esse meio os diversos trabalhos dos alunos.

Uma das possibilidades na formulação de projetos de ensino/aprendizagem de FLE envolvendo Internet - a mais recomendada, p. ex. por Mangenot (2006 : 17) - é fornecer os endereços em que se encontram os textos contendo as informações buscadas e vigiar para que o aluno não se "perca". Outra possibilidade é fornecer orientação para a pesquisa e acompanhar a busca por parte do aluno. Na primeira alternativa, sobra mais tempo a ser empregado em desenvolver a habilidade lingüística que é o objetivo do projeto - no caso que nos interessa, a leitura. A segunda alternativa é mais produtiva no sentido de fazer avançar a autonomia.

Cabe ao professor, em ambas as alternativas, o trabalho prévio de escolha dos temas. Esses serão tanto mais bem aceitos pelos alunos quanto mais eles forem 
"impostos" pelas circunstâncias - tema proposto por um evento do colégio, tarefa pedida por um outro professor do colégio - já que não dependerá do gosto pessoal do professor ou de uma maioria da classe. O trabalho se mostrará então aos alunos como útil e significativo diante do público do colégio. Definido o tema, é preciso um recenseamento dos recursos disponíveis na Internet - os resultados desse trabalho não serão necessariamente entregues ao aluno, mas servirão de parâmetros para a orientação que será dada. Finalmente, com base nas dificuldades específicas encontradas no recenseamento prévio e em orientações gerais da metodologia de pesquisa, deverá ser dado um treinamento para a pesquisa.

\section{O treinamento}

Considerando que o aluno se gaba justamente do seu nível de conhecimento de informática, freqüentemente superior ao do professor, em que sentido será útil um treinamento para o trabalho de pesquisa com Internet? De fato, na realidade entendemos aqui por treinamento uma preparação aos procedimentos do projeto que não são específicos do ensino de FLE. Nesse sentido, consideramos que a pesquisa em Internet representa o maior desafio e o aprendizado mais útil entre os diversos proporcionados por essa metodologia.

O estudo, já citado, da consultoria americana Nielsen Norman Group mostra que adolescentes de 13 a 17 anos são menos hábeis que adultos na tarefa de encontrar informações na Internet. As causas disso, segundo a própria consultoria e analistas, seriam uma dificuldade cognitiva em hierarquizar informações, pouca paciência e 
menor habilidade que o adulto em manter o foco na leitura, além de dificuldade na compreensão de frases elaboradas e no uso dos mecanismos de busca ${ }^{145}$.

Ollivier $(2007: 1)^{146}$ afirma que o aluno tem a aprender:

"A utilização eficaz dos recursos da Internet pede uma aprendizagem por parte do aluno: é preciso, de um lado, que ele conheça a existência dos recursos que podem lhe ser úteis e, de outro lado que ele saiba utilizá-los eficazmente a fim de realizar tarefas concretas. É dever do professor acompanhá-lo nessa aprendizagem, cuja finalidade é conduzi-lo a uma maior autonomia, mais segurança e confiança em si"147.

Em primeiro lugar é preciso mostrar uma postura crítica em relação à fascinação pela Internet. Pantanella ${ }^{148}$ comenta:

\footnotetext{
“quando se está fascinado pelo próprio instrumento (...) não se aprende grande coisa (...) perde-se muito tempo (...) e é extremamente estéril" ${ }^{149}$. Isso porque "o instrumento não informa sobre sua própria utilização nem dá o sentido da utilização que se quer fazer dele".
}

Em seguida, é preciso fazer ver a oportunidade de um aprendizado de pesquisa em Internet. É verdade que, freqüentemente, os alunos têm consciência de que sem uma

\footnotetext{
145 "Nisso eles são bons... ...mas, na hora de navegar na internet, os adultos é que entendem do riscado" Veja, ed. 1896, 16.03.05.

${ }^{146}$ Autor de uma metodologia de projetos chamada DidacTIClang.

147 "L'utilisation eficace des ressources de la Toile demande un apprentissage de la part de l'apprenant : il faut d'une part qu'il connaisse l'existence des ressources qui peuvent lui être utiles et, d'autre part qu'il sache les utiliser efficacement afin de réaliser des tâches concrètes. C'est à l'enseignent de l'accompagner dans cette apprentissage, le but étant de mener l'apprenant à plus d'autonomie, plus d'assurance et de confiance en soi ».

${ }^{148}$ in BERTHAUX (2001: 17) .Os TPE (travaux personnels encadrés), espécie de trabalhos de conclusão de curso, obrigatórios no final do Ensino Médio francês, produziram muitos trabalhos de metodologia de pesquisa em Internet voltados para essa faixa etária, entre os quais os dos autores citados a seguir.

149 « lorsqu'on est fasciné par l'outil lui-même (...) on n'appprend pas grand-chose (...) cela prend beaucoup de temps (...) et c'est extrêmement stérile. » "l'outil ne donne pas lui-même la notice de son utilisation, ni le sens de l'utilisation qu'on veut en faire ».
} 
orientação 150 “passam horas sem encontrar nada”. Ora, é “nas ocasiões em que os professores e os alunos têm projetos em andamento e sentem a necessidade de uma formação indispensável é que essa formação encontra sua eficácia". ${ }^{151}$ Isso porque o ensino de uma metodologia "é um desvio da produção, um investimento, do qual não se vê imediatamente as conseqüências, mas que se revela em seguida muito útil"152.

Beaufils e Blondel (2001 : 31) estudaram o modo com que os adolescentes pesquisam em Internet, em língua materna, distinguindo quais são as dificuldades comuns a todo tipo de pesquisa e quais são específicas desse meio. Com base nessas pesquisas, sugerem instruções e ajuda para melhorar seu desempenho. Segundo eles, os alunos são capazes de encontrar documentos e nesses documentos a resposta que eles consideram adequada, embora para isso consultem um número muito grande de documentos. As pesquisas sobre temas mais específicos produzem resultados melhores e mais rápidos, tirados de fontes mais confiáveis. No caso de temas mais amplos, a pesquisa é mais demorada e a qualidade do resultado geralmente é menor. Algumas condições identificadas por eles para a eficiência na pesquisa são resumidas abaixo:

- Identificar a natureza das informações a encontrar: algum conhecimento prévio do assunto é requerido. Antes de lançar a pesquisa, um planejamento deve inclui a detecção de palavras-chave do assunto, assim como seus sinônimos e termos pertencentes ao mesmo campo semântico. Se possível, deve-se esboçar um plano provisório da resposta. ${ }^{153}$

\footnotetext{
150 «passent des heures à ne rien trouver» Pantanella in BERTHAUX (2001: 19).

151 "dans les occasions où les enseignants et les élèves ont des projets en cours et ressentent la necessité d'une formation indispensable que cette formation trouve son efficacité » Pantanella in BERTHAUX idem : ibidem.

152 «c'est un détour de la production, un investissement dont on ne voit pas de suite les retombées, mais qui s'avère ensuite très utile » Feytout in BERTHAUX idem : ibidem).

${ }^{153}$ A insistência em um procedimento estruturado de forma tão abstrata é criticada por Tricot $(2000: 3)$, que considera mais plausível iniciar a pesquisa por uma exploração do tema já em Internet, como vimos acima no item sobre a leitura em Internet.
} 
- Ter uma idéia mais ou menos precisa da natureza da Internet enquanto biblioteca: os alunos muitas vezes acreditam que a resposta exata a sua pergunta encontra-se em um certo documento, que deve ser encontrado a todo custo. É verdade, porém, como observam os autores, que o 'contrato didático' habitual autoriza os alunos a supor que a resposta pode ser encontrada desde que se sigam os métodos propostos pelo professor.

- Saber usar ferramentas de busca. Cremos que essa última condição não é a mais difícil de ser obtida, seja porque os alunos já possuem noções desses programas, seja porque se trata de uma habilidade técnica, facilmente ensinável. As duas condições anteriores referem-se a noções e competências bem mais complexas. Para chegar a essas competências, os autores insistem em um treinamento específico a ser proposto aos alunos no início do trabalho.

Lembremos, entretanto que se o adolescente encontra dificuldades em efetuar uma pesquisa em sua língua materna, maiores serão essas dificuldades na pesquisa em FLE. Por isso Lancien (1998 : 100) embora ressaltando as possibilidades de uma transferência de conhecimentos interciberculturais, ou seja, referentes a uma habilidade "universal” em relação à informática, recomenda um treinamento lingüístico específico para a pesquisa em Internet: "escolha de palavras pertinentes em relação a um dado domínio, classes de palavras, palavras genéricas / palavras específicas”. ${ }^{154}$

\footnotetext{
154 « choix des mots pertinents par rapport à um domaine donné, classes de mots, mots génériques/mots spécifiques ».
} 


\title{
6. A avaliação
}

Diversas formas de avaliação, tanto do projeto como um todo, quanto da compreensão de leitura que ele prevê, são propostas na bibliografia de FLE. Giasson (2003 : 357), ao tratar do ensino de leitura (em língua materna), menciona a "tarefa integradora" 155 como uma das alternativas para a avaliação em leitura. Considerando essa uma avaliação "significante e motivante" ela descreve com Jalbert e Munn (2001):

\begin{abstract}
"Nessas situações, qualificadas como complexas, várias competências transversais e disciplinares são solicitadas. A situação de avaliação se estende por vários dias, até mesmo por várias semanas. As produções são freqüentemente destinadas a um público: alunos da classe, alunos de outras classes, pais etc [...] Para levar em conta as múltiplas facetas de uma competência, diferentes meios de avaliação são necessários: observação, interrogação oral, entrevista, análise do resultado final. A avaliação conjunta, a avaliação pelos colegas e a auto-avaliação são freqüentemente utilizadas."
\end{abstract}

Enquanto forma de avaliação de compreensão de leitura, a seleção de dados em um texto é proposta desde a abordagem global (Moirand 1982 apud Boyer, Butzbach e Pendanx 2001 : 142). A seleção de trechos em um documento é uma prática comum no decorrer de uma pesquisa. Unguen (2001 : 59) considera que encontrar o documento adequado, em uma pesquisa

\footnotetext{
155 "tâche intégratrice"

156 "Dans ces situations qualifiées de complexes plusieurs compétences transversales et disciplinaires sont sollicitées La situation d'évaluation se déroule sur plusieurs jours, voire plusieurs semaines. Les productions sont souvent destinées à un public : élèves de la classe, élèves des autres classes, parents, etc [...] Pour saisir les multiples facettes d'une compétence, différentes moyens d'évaluation sont nécessaires : observation, interrogation orale, entrevue, analyse du résultat final. La coévaluation, l'évaluation par les pairs et l'autoévaluation sont fréquemment utilisées. »
} 
"é apenas o começo de um trabalho de leitura e interpretação: o documento só vale pelo uso que o reduzirá ao estado de extratos, de citações (...) Trata-se, antes de mais nada, de desconstruir o documento, de fagocitá-lo”. 157

A leitura oralizada em língua materna, que não se confunde com a tradução propriamente dita, é utilizada para avaliação de compreensão de leitura em diversos trabalhos, como, por exemplo, por Pietraróia (1997 : 197).

A grande vantagem do projeto, em termos de avaliação, é que ele permite que essa seja realizada ao longo de todo o processo, tomando como base diversas fases da produção. Segundo Ellis (citado por Mangenot 2006 : 39), o que o aprendiz entende como objetivo do projeto, ou seja, o produto final, a ser apresentado para a comunidade, não é sempre o mesmo que o professor entende, pois este está interessado antes no desenvolvimento de determinadas habilidades, necessárias para chegar ao produto desejado, do que no próprio produto.

\section{A autonomia}

A pedagogia dos projetos de aprendizagem faz referência, em mais de um sentido, ao termo autonomia. Etimologicamente, autonomia é a capacidade da pessoa de seguir suas próprias leis. Na pedagogia de FLE, uma interpretação radical do termo foi pregada por Holec (1990 : 82) que define a autonomia como "saber aprender",

\footnotetext{
157 «n'est que le début d'un travail de lecture et d'interpretation : le document ne vaut que par l'usage que le réduira à l'état d'extraits, de citations.(...) Il s'agit plutôt de déconstruire celui-ci, de le phagocyter.»

158 “Saber aprender é portanto possuir os conhecimentos e a capacidade de por em prática esses conhecimentos que permitem definir, realizar, gerir e avaliar um aprendizado.Mas esses conhecimentos e essas capacidades não são inatas: elas devem ser adquiridas." "Savoir apprendre c'est donc posséder les connaissances et la capacité de mise en oeuvre pratique de ces connaissances qui permettent de
} 
sentido de assumir a plena responsabilidade de decisão sobre seu aprendizado ${ }^{159}$, antes mesmo de começar esse aprendizado.

Uma segunda acepção ${ }^{160}$ refere-se ao processo de aprendizagem conduzido com independência em relação ao professor. Dentro da pedagogia de projetos, vários momentos permitem ao aluno tomar decisões e trabalhar sem a interferência do professor. Nesses momentos, o professor deve ficar disponível para resolver problemas, sem fornecer respostas prontas, mas guiando o questionamento de forma a permitir ao aluno encontrar sozinho as respostas, sempre que possível. Evidentemente, não se deve permitir um desvio excessivamente grande do foco do trabalho, nem obrigar o aluno a perder um tempo excessivo, terminando por se desencorajar. "Tudo é uma questão de dosagem", 161 afirma Demaizière (2003: 5).

O terceiro sentido do termo refere-se à capacidade de utilizar as competências adquiridas em situação de comunicação real. A autonomia de leitura, portanto, seria a capacidade do aluno de servir-se realmente de suas habilidades de leitura, em toda a medida em que ele as possui. Nesse sentido, a autonomia de leitura beneficia-se da autonomia didática do projeto, exposta no parágrafo acima, visto que permite ao aluno avaliar sua capacidade real de leitura em uma situação em que ele se sente em relativa independência. A falta de uso é uma das causas da perda do aprendizado das línguas na escola. Se o aluno estiver convencido de que é capaz de ler em francês, provavelmente será capaz de encontrar ocasiões de empregar essa competência - e com isso

définir, réaliser, gérer et évaluer un apprentissage. Mais ces connaissances et ces capacités ne sont pas innées : elles doivent être acquises.»

159 incluindo a determinação dos objetivos, a definição dos conteúdos e progressões, a escolha dos métodos e das técnicas; o ritmo, momento e lugar do estudo e a avaliação da aquisição realizada. (Cfr HOLEC $1990: 82-83$ )

${ }^{160}$ As três acepções do termo são mencionadas pelo Diccionnaire de didactique du français LES, verbete Autonomie.

161 «Le tout est affaire de dosage » DEMAIZIÈRE. O parágrafo é um resumo de trecho da conferência Autonomie : objectif ou prérequis? 
desenvolvê-la - seja, por exemplo, na pesquisa escolar, seja em outras situações, no Ensino Médio, ou depois na Universidade.

\section{f. A interdisciplinaridade}

A interdisciplinaridade significa, na exposição de Edgar Morin (1994 : 7), "que diferentes disciplinas se sentam à mesma mesa (...) [também com finalidade de ] trocas e cooperação". Seu quase sinônimo polidisciplinaridade “constitui uma associação de disciplinas em função de um projeto ou de um objeto que lhes é comum"162, enquanto transdisciplinaridade (na definição de Arber 1996 : 2) significa

"levar seu olhar além de seu domínio próprio e se interessar por um outro domínio" sendo que "um curso transdisciplinar abre ao estudante uma janela sobre os elementos essenciais, as estratégias de trabalho e os conteúdos fundamentais de uma disciplina outra que aquela que é o objeto de seus próprios estudos ${ }^{163}$.

Além dessas definições, que podem parecer excessivamente ambiciosas para um trabalho escolar, a atitude interdisciplinar, que pressupõe a metodologia dos projetos, permite fazer ver ao aluno que as disciplinas escolares não têm um fim em si mesmas, mas mantêm relações constantes com as demais, que participam do patrimônio de conhecimentos que constitui a cultura. É essencial para o aluno, para sua motivação e para a eficiência do esforço que ele despende no aprendizado, a noção de que aprender

\footnotetext{
162 "l'interdisciplinarité peut signifier purement et simplement que différentes disciplines se mettent à une même table (...) inter-disciplinarité peut vouloir dire aussi échange et coopération,(...) La polydisciplinarité constitue une association de disciplines en vertu d'un projet ou d'un objet qui leur est commun »

${ }^{163}$ Par transdisciplinaire nous entendons ici "porter son regard au delà de son domaine propre et s'intéresser à un autre domaine". En conséquence, un cours transdisciplinaire ouvretil à l'étudiant une fenêtre sur les éléments essentiels, les stratégies de travail et les contenus fondamentaux d'une autre discipline que celle qui fait l'objet de ses propres études.
} 
francês o aproxima dessa “mesa" a qual estão sentadas todas as disciplinas. É interessante que a colaboração entre as disciplinas, exemplo para o aluno do que deve ser sua colaboração inter pares, leve à articulação de projetos de aprendizagem conjuntos, ao invés da competição feroz pela atenção dos alunos, com vistas a garantir seu desempenho no vestibular!

Da parte do professor de Francês, é preciso bom senso para avaliar sua posição "minoritária" em relação a outras disciplinas no currículo escolar brasileiro. Não é o professor de Física - forte de sua importância no vestibular, sobretudo para os alunos que se dirigem às carreiras de Ciências Exatas - que vai procurar o colega de Francês para propor-lhe um projeto conjunto. Mas é este último que tem a ganhar oferecendo suas aulas para um projeto - que vai ensinar a seus alunos Astronomia, História da Tecnologia, p.ex., além de Francês, - mas que vai também associar o Francês em suas mentes com conhecimentos científicos aprofundados e com um sucesso escolar atingido por uma via inesperada: a leitura em francês.

\section{Conclusão do Capítulo IV}

Procuramos justificar, no presente capítulo, a adoção de um conjunto de conceitos pedagógicos com vistas a uma metodologia da leitura em FLE. O emprego da leitura como um objetivo pedagógico independente é justificável sob vários pontos de vista, de acordo com os PCNs e as análises do Quadro Comum Europeu de Referência para as Línguas. A larga metodologia já desenvolvida para o ensino dessa habilidade pode ser aproveitada com proveito para o uso da Internet. A escolha dos textos a serem empregados em aula deve privilegiar os textos autênticos, por sua riqueza lingüística; os 
textos longos, necessários para o desenvolvimento da autonomia de leitura em LE; assim como levar em conta as regularidades que tornam certos gêneros mais adaptados do que outros: em nosso caso específico, o gênero divulgação científica se revela bastante adequado. O tipo de leitura que será efetuado no decorrer do trabalho é uma leitura ativa, com vistas à composição de um resumo através de uma seleção de trechos; uma leitura de compreensão, mais do que de exploração das formas lingüísticas, e uma leitura em que a motivação tem um papel fundamental na mobilização de aquisições anteriores. A pedagogia de projetos é apresentada como a modalidade ideal para o trabalho com Internet, podendo constituir percursos de aprendizagem contextualizados, autênticos, complexos, ativos, geradores de um desequilíbrio cognitivo benéfico ao aprendizado, e com resultados voltados para a comunidade. Os aspectos a serem definidos na criação de um projeto são duração, objetivos, competência, público e domínio temático, tipo de resultado esperado, natureza do suporte, ligação com a vida real, participação na tarefa, instrumentos requeridos, recursos de retaguarda e plano de vôo. Um treinamento específico para a realização do projeto é fortemente recomendada, consistindo sobretudo na formulação de um plano de pesquisa e em uma sistematização das noções sobre a natureza da Internet e seus sistemas de busca. A avaliação do projeto pode ser efetuada de diversas maneiras e durante todo o decorrer do processo, consistindo principalmente na observação das habilidades postas em prática para a confecção do produto final. A autonomia buscada pelos projetos consiste em certo grau de independência em relação ao professor no decorrer da aprendizagem e ainda na utilização das competências adquiridas em situação de comunicação real. Por interdisciplinaridade entende-se “ o sentar à mesma mesa das diversas disciplinas para 
trocas e cooperação" ${ }^{164}$, sendo proposto que essa iniciativa possa partir também do professor de Francês.

De todo o exposto nessa primeira parte, concluímos que a adoção de projetos interdisciplinares de leitura em Internet pode ser bastante benéfica para a aprendizagem de FLE. Ao examinarmos a aplicação prática que deles fizemos, procuraremos comprovar essa opinião.

${ }^{164}$ MORIN (1994 : 7). 


\section{Projetos interdisciplinares de leitura em FLE na Internet para o Ensino Médio}

Os projetos que descrevemos, envolvendo Internet e leitura em FLE, são uma iniciativa da área de Francês, e propõem um trabalho em conjunto com outra disciplina para o objetivo comum. O trabalho se desenvolve em horário de aula de Francês e, eventualmente, da outra disciplina ou em horário extra, posto à disposição dos alunos para esse fim. O local de trabalho é o laboratório de informática do Colégio.

Tomamos como eixos básicos para a elaboração dos projetos os seguintes elementos, explanados teoricamente nos capítulos acima: a leitura, como competência e como instrumento de aquisição de competências em FLE; a Internet, como ambiente afetivamente positivo para o trabalho com adolescentes, como fonte inesgotável de recursos FLE, como tecnologia acessível, cujo emprego é recomendado pelos PCNs, pela escola e pela sociedade, como recurso pedagógico interessante, mas cujo emprego pede ainda estudos e propostas pedagógicas; a interdisciplinaridade como princípio filosófico que combate a excessiva separação entre os diversos campos do saber, em benefício de um ensino que mostra a coerência entre as disciplinas, como meio de mostrar a utilidade de FLE, em um contexto de Ensino Médio, mas com vistas a um futuro acadêmico, profissional e cultural; a busca de uma autonomia de uso e de aprendizagem que permita um desenvolvimento pós-escolar da competência em FLE. 


\section{Metodologia da pesquisa}

Algumas idéias básicas sobre a pesquisa aplicada ao uso da tecnologia em pedagogia de FLE são explanadas por Mangenot (2005 : 313-322). Segundo ele, entre os objetivos dessa pesquisa estiveram principalmente até o presente a

"observação dos processos de uso e de aprendizagem induzidos por esses novos suportes" e a

“ identificação das variáveis que, tanto no nível da produção quanto no da recepção, permitiria otimizar o papel desses suportes na aprendizagem" $" 165$.

De fato, não é pequena

"a dificuldade metodológica" de "responder à questão 'o que observar e como?': as variáveis de uma situação de aprendizagem são de tal modo interligadas que freqüentemente é artificial neutralizar algumas para se concentrar em outras. "166

Por isso, finalmente, a opção adotada pela pesquisa FLE/TICE foi:

“um procedimento em dois tempos complementares:

\footnotetext{
165 « - observation des processus d'usage et d'apprentissage induits par ces nouveaux supports. - identification des variables qui, tant au niveau de la production qu'à celui de la réception, permettraient d'optimaliser les rôles de ces supports dans l'apprentissage ».

166 «Difficulté méthodologique, enfin, à répondre à la question « quoi observer et comment ? : : les variables d'une situation d'apprentissage sont tellement interreliées qu'il est souvent artificiel d'en neutraliser certaines pour se concentrer sur d'autres »
} 
- observação precisa do aprendiz e principalmente de sua navegação no CDrom (ou site Internet),

- questionários e entrevistas destinados ao mesmo tempo a conhecer o nível de domínio do instrumento, as representações sobre a multimídia e sobre a aprendizagem, a maneira com que a tarefa (se for o caso) tinha sido vivida"167.

Isso mostra, para Mangenot,

"a escolha de um paradigma de pesquisa exclusivamente qualitativo, diferente dos paradigmas quantitativos utilizados em ciências cognitivas" $" 168$ pois apenas aquele pode "enquanto quadro teórico(...) levar em conta, de maneira sistemática, as numerosas variáveis das situações organizadas de aprendizagem das línguas" ${ }^{169}$, gerando uma pesquisa "cujo fio condutor se interessa pelo lugar do humano (professor, estudante ou simples utilizador) em relação aos dispositivos tecnológicos, na construção e transmissão dos saberes lingüísticos e não lingüísticos. ”170

A pesquisa qualitativa, segundo Ciribelli (2003 : 57) é aquela em que o resultado pede "um tratamento lógico secundário, feito pelo pesquisador", ou seja, pede uma interpretação dos dados e de sua adequação aos objetivos da pesquisa. Esse

\footnotetext{
167 «Nous avons finalement opté pour une démarche en deux temps complémentaires : observation précise de l'apprenant et notamment de sa navigation dans le cédérom (ou le site Internet), questionnaires et entretiens destinés à la fois à connaître le niveau de maîtrise de l'outil, les représentations sur le multimédia et sur les apprentissages, la manière dont la tâche (le cas échéant) avait été vécue ».

168 "le choix d'un paradigme de recherche exclusivement qualitatif, à la différence des paradigmes quantitatifs utilisés en sciences cognitives »

169 «Au plan du cadre théorique,(...) peuvent prendre en compte, de manière systémique, les nombreuses variables des situations instrumentées d'apprentissage des langues. »

170 «dont le fil conducteur s'intéresse à la place de l'humain (enseignant, étudiant ou simple utilisateur) par rapport aux dispositifs technologiques, dans la construction et la transmission de savoirs langagiers et non langagiers »
} 
procedimento constituiria, do ponto de vista metodológico, um estudo de caso, definido como

"uma investigação empírica que

- $\quad$ investiga um fenômeno contemporâneo dentro de seu contexto da vida real, especialmente quando

- $\quad$ os limites entre o fenômeno e o contexto não estão claramente definidos (...)

- $\quad$ enfrenta uma situação tecnicamente única em que haverá muito mais variáveis de interesse do que pontos de dados e, como resultado,

- $\quad$ baseia-se em várias fontes de evidências, (...)

- [beneficiando-se] do desenvolvimento prévio de proposições teóricas para conduzir a coleta e a análise de dados" (YIN 2005 : 32-34)

Cremos reunirem-se em nosso estudo as condições necessárias para considerá-lo um estudo de caso: os Projetos são estudados "dentro de seu contexto da vida real" , no qual é impossível delimitar a influência dos procedimentos pedagógicos do colégio como um todo e daqueles empreendidos em função dos Projetos e, por isso, "os limites entre o fenômeno e o contexto não estão claramente definidos". O número de conceitos pedagógicos que intervieram na concepção dos Projetos, como vimos, é bastante grande e, com isso, "haverá muito mais variáveis de interesse do que pontos de dados", o que leva a procurar resultados conclusivos "em várias fontes de evidências", tais como a análise dos textos produzidos, os depoimentos e a observação do trabalho de leitura, conduzidos de acordo com “o desenvolvimento prévio de proposições teóricas”. A experimentação e sua análise desenvolver-se-ão, portanto, em uma pesquisa qualitativa, 
do tipo estudo de caso, combinando observação do comportamento do aluno e de seu trabalho, questionários e entrevistas.

\section{Histórico dos projetos}

\section{a. Inserção no projeto pedagógico do Colégio}

A política do Colégio, em termos de ensino de LE, é objeto de um documento constante do site da instituição ${ }^{171}$, denominado Leitura e Línguas Estrangeiras no Projeto Pedagógico do Colégio ${ }^{172}$. Neste, a língua estrangeira é vista inicialmente como ferramenta de aprendizagem:

[ele] "considera a formação escolar básica como um processo de aquisição de ferramentas que permitiam ao educando um aprendizado continuado (...)Nessa perspectiva, a aquisição competente, tanto da língua materna quanto de duas línguas estrangeiras modernas é fundamental. O domínio dessas línguas abre o campo de possibilidades de aquisição de conhecimentos.

Igualmente é visada, também através dela, uma compreensão aprofundada de aspectos culturais:

"do ponto de vista de formação humana, de contato do aluno com o patrimônio artístico e cultural da humanidade, que valorizamos muito, um bom conhecimento do português, do inglês e do francês também são essenciais."

Ora, desse ponto de vista, projetos que adotam uma abordagem interdisciplinar facilitam a compreensão de que a língua é porta de uma entrada na cultura estrangeira.

\footnotetext{
171 www.saomauro.org.br

172 Transcrito no Anexo 7.
} 
O papel da pedagogia de projetos nas escolhas didáticas do Colégio não é central, embora preencha uma função importante, como explica a diretora Ivone Fedeli (entrevista em 06.05.08) ${ }^{173}$ :

"Em primeiro lugar, é preciso notar que a nossa escola não é uma escola que trabalhe exclusivamente com projetos. Nós temos, ao contrário, um programa de conteúdos que devem ser estudados ao longo de cada um dos anos escolares. Mas, por outro lado, nós consideramos que os projetos são importantes, na medida de possibilitar uma aplicação mais prática e mais imediata de conhecimentos adquiridos. E exatamente por ser uma aplicação mais prática e mais imediata, gera-se um interesse com uma maior facilidade e isso - é claro, todos nós sabemos o quanto a questão do interesse é importante no aprendizado efetivo. Então, embora nós não sejamos uma escola que só trabalha com projetos, nós consideramos os projetos importantes no total do aprendizado deles. E por isso nós repetimos, ao longo do ano, vários eventos, em que projetos diferenciados, inclusive projetos de várias áreas, muitos deles interdisciplinares, são trabalhados. E possibilitamos grandes ocasiões pedagógicas em que há a oportunidade de montar esses projetos e de apresentá-los (---) [negritos nossos].

A primeira vantagem na aplicação de projetos, portanto, conforme apontada por I. Fedeli é a "aplicação mais prática e mais imediata de conhecimentos adquiridos", capaz de gerar "interesse com uma maior facilidade”. A inserção dos projetos que estamos examinando na política do Colégio se dá principalmente através dos vários eventos anuais: Feira de História e Geografia (FECLIO), que conclui o primeiro bimestre, Feira de Ciências (FELUMEN), no fim do segundo bimestre e Feira de Artes (SMART), no encerramento do ano letivo, além das Olimpíadas e eventos externos dos quais o Colégio participa - exemplo disso foi o Projeto Apostila de Astronomia, criado

\footnotetext{
${ }^{173}$ Transcrita no Anexo 4.
} 
para apoiar a preparação dos alunos para a Olimpíada Brasileira de Astronomia em 2006. O papel dos projetos interdisciplinares nas Feiras do colégio foi também objeto de comentário de Ivone Fedeli:

(...) essas Feiras, elas têm vários objetivos, para nós: (...) um aspecto social importante da escola, mas que também está envolvido em toda questão pedagógica, é a participação dos pais, a participação da família, a participação até da comunidade do bairro, de tudo aquilo que envolve a escola. Então (...) para eliminar um pouco essa dificuldade de trazer os pais (...), nós fazemos um trabalho conjugado.(...) A cada vez. que acontece(...) a Reunião de Pais e Mestres - nós juntamos a isso o que nós chamamos de feiras (...) essas feiras são exatamente a ocasião dos professores poderem preparar esses projetos interdisciplinares. É também, do ponto de vista da integração do colégio no grupo de pais, no grupo do bairro, é a ocasião do colégio mostrar o trabalho de seus alunos. Então, toda essa questão, o fato de que vêm os pais, de que vêm outras pessoas, tudo isso gera um interesse muito grande nos alunos. Então são ocasiões de aprendizado muito privilegiadas, e por isso muito importantes para o nosso projeto global.

O segundo motivo apontado por I. Fedeli, portanto, para a inserção dos projetos é favorecer a integração dos pais e da comunidade no projeto pedagógico do Colégio. Também esse é um fator que determina um grande interesse dos alunos em produzir um trabalho que vai ser mostrado para os pais e para a comunidade. Entretanto, essa não é a única causa apontada para a grande motivação verificada durante a confecção do trabalho. Seguindo a análise de I. Fedeli,

"além de ter participado como visitante da Feira, eu participei também como visitante da sala multimídia, quando os projetos estavam sendo preparados. (...) eles estavam preparando os projetos, fazendo a pesquisa, pesquisando ilustrações, eu fiquei contente porque eu achei que eles demonstravam um grande interesse. E o que eu acho que 
talvez seja o melhor, principalmente os rapazes, com quem eu conversei, era um projeto que estava mais focado naquilo que eles estavam aprendendo, no que propriamente no francês. Para eles aquilo não era um trabalho de Francês. Eles estavam aprendendo sobre propulsão, os modos de propulsão dos barcos, os tipos de energia, e eles estavam muito interessados nisso, de modo que o francês entrava com uma facilidade muito grande. O francês era um instrumento que estava servindo muito bem para o que eles queriam e para o que eles precisavam. E isso me pareceu muito bom (...) de repente o francês era fácil, e era interessante e era um instrumento muito bom para eles. $O$ trabalho... me pareceu um trabalho muito bom e o que mais me chamou a atenção foi essa questão: do francês transformado num instrumento útil para eles. Eles estarem aprendendo língua sem aquele foco na língua. Aí a língua ficava uma coisa extremamente interessante. Porque eliminava aquela clássica pergunta dos estudantes, que é muito freqüente nos estudantes que têm preguiça mas um pouco é a pergunta de todo estudante, que é: "Para que, eu estou aprendendo isso?" Ali não tinha "Para que eu estou aprendendo francês?" O francês era um instrumento muito importante para eles.

O terceiro ponto de interesse para o Colégio e também causa de motivação para os alunos, portanto, é o uso do francês como instrumento de aprendizado. Esse aspecto do trabalho é muito realçado pela professora de História, Laura Pinca da Palma (entrevista concedida em 13.05.08):

"sem dúvida, o francês é uma ferramenta muito importante para o estudo de História, porque a maioria, com exceção de História do Brasil, a maior parte da História Geral está na língua francesa, normalmente, em francês, até mais do que em inglês, então para eles é...

Então é um campo em que o francês predomina?

Isso, sem dúvida. Então o fato de eles trabalharem com o francês, para História, é bem importante" 
A característica de instrumento de aprendizado, aliado a uma pesquisa com tema escolhido pelo próprio aluno, estimula a busca da compreensão em leitura, e faz passar um aprendizado considerado mais difícil - a língua estrangeira - para chegar a um mais fácil - o tema do projeto interdisciplinar. De fato, entre as duas matérias, estabelece-se para o aluno, uma complementaridade:

“É vantajoso para o próprio desenvolvimento deles, porque dominando o francês eles aprendem mais História e, ao mesmo tempo, aprendem francês. Já que eles têm que aprender o conteúdo de História, pesquisando em francês, isso dá uma possibilidade de eles já melhorarem o francês deles (...)”

Outros pontos de interesse nos projetos interdisciplinares foram apontados na entrevista de L. Palma. Entre eles, o trabalho dirigido à comunidade, mostrando uma articulação interdisciplinar efetiva:

“(...) é interessante para os pais, que possam ver o trabalho que eles estão desenvolvendo relacionando todas as matérias que há no Colégio, utilizando, já no colégio, o francês como instrumento de pesquisas".

Do mesmo modo, ela observa as vantagens do trabalho interdisciplinar para a motivação e para o desenvolvimento cognitivo:

"E todo o processo, o trabalho interdisciplinar é importante para o desenvolvimento deles, porque eles acabam gostando mais. Eu percebo isso, eles acabam gostando mais porque tem mais relações, é uma coisa mais ampla, né?" 
Uma última e surpreendente vantagem do trabalho interdisciplinar (citada na entrevista em primeiro lugar) refere-se à colaboração entre as disciplinas:

"como História tem um determinado conteúdo a ser tratado é sempre bom que a gente possa ter a colaboração de outras matérias que não têm talvez uma exigência tão grande de conteúdos, como é o Francês, mas é uma ferramenta, um meio de aprender e que a gente possa preencher essas matérias com os conteúdos que a gente precisa...(...) isso é uma coisa que eu defendo até que se estenda a outras matérias, como Computação, e isso porque? porque assim as crianças podem trabalhar com o conteúdo que eles estão vendo em História, no caso, ou em Geografia, de maneira mais intensa."

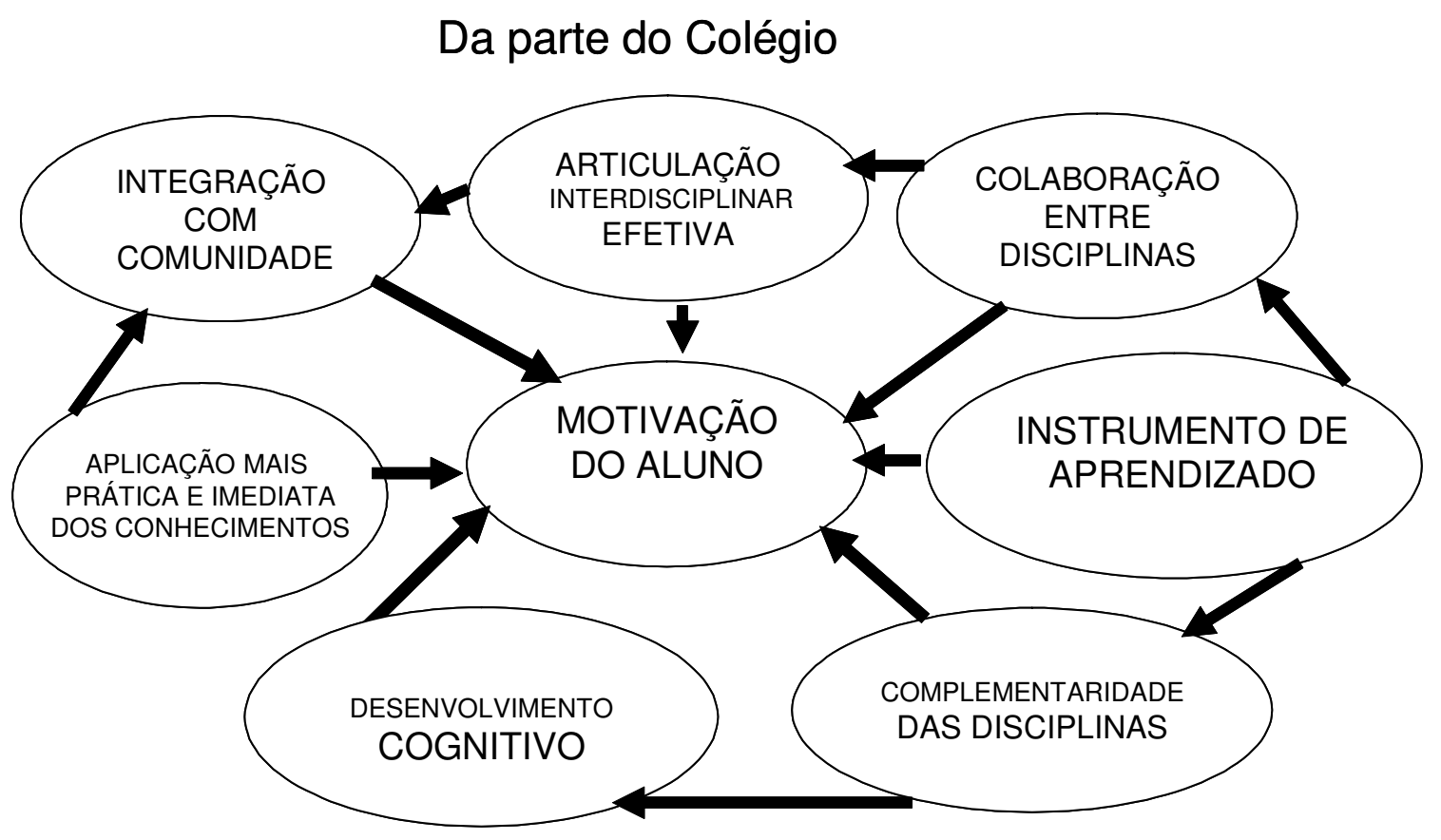

Da parte do aluno

Figura 4: Formas de inserção dos PILFLEIEM no projeto pedagógico do Colégio 
A figura ilustra a convergência de aspectos do projeto suscetíveis de produzir o interesse do aluno e as relações que esses aspectos mantêm entre si. Da parte do Colégio, o entrosamento e a colaboração entre professores são indispensáveis para uma articulação interdisciplinar efetiva e eficiente, a qual valoriza o projeto pedagógico do Colégio por ocasião de um encontro com as famílias e a comunidade. Do mesmo modo, a colaboração entre disciplinas permite otimizar o estudo, provendo conteúdos significativos às matérias de caráter mais instrumental. Da parte do aluno, a perspectiva de mostrar à comunidade o trabalho a ser produzido, pela aplicação mais imediata dos conhecimentos adquiridos, é um fator de motivação e um dos objetivos possíveis para o trabalho com projetos. Por sua vez, ao utilizar uma disciplina como instrumento de aprendizado, ele dá uma primeira resposta a uma questão mais ou menos insistente, mas

sempre presente: “para que estudar essa matéria”? É essa uma maneira de chegar à noção da complementaridade das diversas disciplinas, objetivo básico da abordagem interdisciplinar. Finalmente, o estabelecimento de relações entre temas e disciplinas favorece o desenvolvimento cognitivo e a motivação.

\section{b. Os projetos anteriores}

Os projetos interdisciplinares de leitura em FLE na Internet para o Ensino Médio estão em 2008 em seu quarto ano de aplicação. Uma série de projetos e testagens, descritos a seguir, serviram para a elaboração de hipóteses de pesquisa e para o aperfeiçoamento da metodologia dos Projetos. Na presente dissertação, analisaremos à parte, mais detalhadamente, apenas um deles: o Projeto Histoire de la technologie maritime. Os demais serão explanados brevemente, do mais recente para o mais antigo. 
QUADRO DESCRITIVO DOS PROJETOS

\begin{tabular}{|c|c|c|c|c|c|}
\hline TÍTULO & ANO & DISCIPLINA & EVENTO & PRODUTO & $\begin{array}{c}\text { COMPETENCIA } \\
\text { EMPREGADA }\end{array}$ \\
\hline $\begin{array}{c}\text { Histoire de la } \\
\text { Technologie } \\
\text { Maritime }\end{array}$ & 2008 & História & $\begin{array}{c}\text { Feira de } \\
\text { História/Geografia: } \\
\text { II FeClio }\end{array}$ & $\begin{array}{c}\text { Apresentação em } \\
\text { Power Point }\end{array}$ & $\begin{array}{c}\text { Leitura para } \\
\text { pesquisa, seleção } \\
\text { de trechos }\end{array}$ \\
\hline $\begin{array}{c}\text { Russie } \\
\text { Astronomie }\end{array}$ & 2007 & História/Geografia & $\begin{array}{c}\text { Feira de } \\
\text { História/Geografia: } \\
\text { I FeClio }\end{array}$ & $\begin{array}{c}\text { Apresentação em } \\
\text { Movie Maker }\end{array}$ & $\begin{array}{c}\text { Leitura, seleção } \\
\text { de trechos, } \\
\text { tradução }\end{array}$ \\
\hline $\begin{array}{c}\text { Apostila de } \\
\text { Astronomia }\end{array}$ & 2006 & Física & $\begin{array}{c}\text { Feira de Ciências: } \\
\text { FeLumen }\end{array}$ & $\begin{array}{c}\text { Apresentação em } \\
\text { Power Point }\end{array}$ & $\begin{array}{c}\text { Leitura para } \\
\text { pesquisa, seleção } \\
\text { de trechos }\end{array}$ \\
\hline $\begin{array}{c}\text { Guerra dos Cem } \\
\text { Anos }\end{array}$ & 2005 & Física & $\begin{array}{c}\text { Olimpíada } \\
\text { Brasileira de } \\
\text { Astronomia }\end{array}$ & Apostila & $\begin{array}{c}\text { Leitura, seleção } \\
\text { de trechos, } \\
\text { tradução }\end{array}$ \\
\hline $\begin{array}{c}\text { Tratados e } \\
\text { Grupos em } \\
\text { Política } \\
\text { Internacional }\end{array}$ & 2004 & Geopolítica & --- & Texto informatizado & $\begin{array}{c}\text { Leitura, seleção } \\
\text { de trechos, } \\
\text { tradução }\end{array}$ \\
\hline
\end{tabular}

Tabela 6: Quadro descritivo dos Projetos Interdisciplinares

\section{b.1. O projeto Russie}

Esse projeto foi preparado para a II FeClio, em 2007. Ele consistiu em pesquisa em francês sobre a geografia e história da Rússia, e apresentação em programa Movie Maker, com texto escrito em francês, animação, música e tradução portuguesa do texto gravadas. A divisão dos grupos e escolha dos temas foi feita pela professora de Geografia e História, segundo parâmetros adequados à avaliação de sua disciplina. A classe, no primeiro ano do Ensino Médio, tinha 11 alunos (sete moças e quatro rapazes), particularmente interessados em Francês, bons leitores de maneira geral, tendo dois deles sido aprovados em exames do DELF A4, (atualmente equivalente ao A2). 
Os quatro subitens da pesquisa foram Climat, Végétation, e Relief de la Russie e La Chute des Romanov. A classe dividiu-se em trios e quartetos, pesquisando os seguintes aspectos:

1. Climat: Pedro, José Luiz, Robson e Eduardo

2. Végétation: Jéssica Micaela, Jéssica Reketis e Morganna

3. Rélief de la Russie: Débora, Luiza e Agatha

\section{La Chute des Romanov : Beatriz e Camila}

A pesquisa se desenvolveu durante quatro semanas, em aulas de Francês e de História. Cada grupo pesquisou em sites de busca, sem indicação de endereços, com orientação da professora quanto a palavras-chave. A leitura foi, de maneira geral, bastante produtiva, resultando em textos coerentes e com um bom conteúdo. Após a confecção dos slides em Power Point e tradução dos textos, os grupos enviaram seus trabalhos para a dupla Pedro e José Luiz, que se encarregou da gravação dessa tradução acompanhada de música, de modo que, durante a FeClio, a apresentação não tinha necessidade de uma exposição por parte dos autores dos textos. Essa apresentação se desenrolou em muitas sessões, no decorrer da Feira, em sala fechada, para grupos de visitantes. A avaliação por parte desses visitantes foi bastante positiva.

\section{b.2. O projeto Astronomie}

A descrição desse projeto constou do Relatório de Qualificação, sendo por isso mais extensa que a dos demais.

\section{Objetivos}


O objetivo metodológico, para a disciplina Francês, desse projeto, foi o desenvolvimento da habilidade de leitura em francês, através da compreensão de um volume relativamente grande de textos, de gênero divulgação científica, com a finalidade de efetuar uma pesquisa, seleção e reformulação desse material em um texto próprio, e, finalmente, exposição em português do texto completo da classe no decorrer da Feira de Ciências.

\section{Caracterização do grupo}

O trabalho foi realizado com 14 alunos do $1^{\circ}$. ano do Ensino Médio, com idades entre 14 e 17 anos. Desses alunos, 9 cursam Francês desde a Educação Infantil (são Alessandra, Augusto, Catarina, Henrique, Igor, Paulo, Renata, Thiago e Tomás), 3 estão em seu $3^{\circ}$. ano de Francês na escola (Adolfo, Felipe e Raphael), 1 esteve na escola por 6 anos, em 3 períodos diferentes (Tony) e 1 é iniciante (Carolina). Entre os alunos antigos, 1 possui o DELF equivalente ao antigo A4 (Henrique).

\section{Planejamento}

O Projeto Interdisciplinar Física-Francês Astronomie foi preparado para a Feira de Ciências do Colégio de 2006: II FELUMEN, realizada em 8 de julho de 2006. O trabalho consistiu em uma série de apresentações de slides em Power Point, com texto em francês e explicações em português pelos alunos para os visitantes da Feira. O texto baseou-se em parte nas pesquisas efetuadas para a Apostila de Astronomia, confeccionada pelos alunos no $1^{\circ}$. bimestre de 2006. Com base na satisfação dos grupos com seus temas e colegas, houve uma pequena reordenação, que resultou nas seguintes equipes:

1 - Les corps celestes (Thiago e Paulo) 
2 - Systeme Solaire (Henrique)

3 - Fusées (Felipe e Adolfo)

4 - Histoire de l'astronomie (Carolina e Catarina)

5 - Conquête Spatiale (Alessandra e Renata)

6 - Satellites et sondes (Tony e Igor)

7 - Le Corps Humain dans l'Espace (Augusto)

8 - Big Bang (Raphael e Tomás)

A nova pesquisa em sites de língua francesa (ao menos dois textos para cada equipe), a formulação do texto em francês e a elaboração da apresentação em Power Point se realizaram durante a última semana de aulas do primeiro semestre, que foi dedicada inteiramente à preparação da Feira de Ciências. O tempo empregado para a execução do projeto - entre a sala de aula e o laboratório de informática, com a presença da professora - foi de cerca de dez horas aproximadamente.

\section{Procedimentos}

\section{Divisão dos temas e dos grupos}

Dois alunos, Henrique e Augusto, bastante hábeis em leitura em francês, preferiram trabalhar sozinhos, apenas por não ter obtido interessados para os temas de sua predileção. Ambos, entretanto, colaboraram com as demais equipes: Henrique é o autor do Index e Augusto ajudou na pesquisa de outros temas. Carolina e Raphael queixaram-se de pouca participação de seus colegas, respectivamente Catarina e Tomás, 
na pesquisa. Tomás, entretanto, compensou essa deficiência, liderando a exposição oral de seu tema. Felipe é um entusiasta dos foguetes e pediu a inclusão desse tema na lista proposta inicialmente.

\section{Pesquisa em sites de língua francesa.}

Apesar da orientação para que fossem conservadas os endereços dos sites utilizados na pesquisa, apenas um grupo incluiu essas indicações no texto - Big Bang (Raphael e Tomás). De maneira geral, entretanto, a pesquisa se realizou a partir do portal de astronomia amadora http://www.astrosurf.com/, seguindo as listas temáticas propostas pelo site ou através de pesquisa de palavras-chave. Outro site indicado pelo professor de Física foi www.astronomes.com . A pesquisa diretamente no site Google também foi utilizada, seguindo orientação da professora de buscar a palavra-chave do tema, com a indicação de língua francesa, na página de pesquisa avançada. Em todos os grupos, ao menos dois textos foram efetivamente consultados. Alguns alunos, entretanto, visitaram, mais ou menos demoradamente, um número bem maior de sites. A exigência de apresentação do texto final em francês fez com que os alunos realmente se ativessem a pesquisar em sites de língua francesa.

\section{Composição do texto.}

O texto final foi composto sobretudo através de seleção de frases dos textos originais consultados, com algumas modificações para resumir ou ligar trechos entre si. Por isso, considero que se deve julgar esse texto mais como resultado de uma boa compreensão de leitura em francês do que como um trabalho de produção de textos originais. Alguns alunos, em certos lugares, entretanto, tentaram compor textos originais, principalmente diante da carência de textos que dissessem exatamente o 
desejado. Exemplo disto é o slide inicial do item Histoire de l'Astronomie, de autoria de Carolina.

\section{Primeira revisão com a professora}

Uma primeira revisão foi feita durante e logo após a composição do texto pelas equipes. Erros de compreensão de leitura que resultavam em afirmações incorretas ou imprecisas, faltas gramaticais ou ortográficos foram eliminados nessa fase de correção.

\section{Pesquisa de imagens}

Para a pesquisa de imagens, nem sempre os alunos pesquisaram em francês, pois não consideravam isso como importante, visto que não implicava em confecção de texto. Entretanto, em ordem de frequiência, grosso modo, encontramos pesquisa de imagens realizadas com palavras-chave em português, depois em francês e em seguida em inglês.

\section{Elaboração da apresentação em Power Point}

Para a apresentação em Power Point, os textos tiveram que ser novamente revistos para adequação ao tamanho conveniente para o slide. Após a junção de texto, imagens e animação, o trabalho de cada equipe foi revisto pela classe toda.

\section{Treino para a apresentação oral.}

Todos os alunos da classe estudaram para expor o texto todo. Para isso se reuniram no último dia que antecedeu a Feira, em grupos de quatro ou cinco, diante de um micro, com a professora, e cada um expôs e ouviu a exposição dos demais colegas em português, a partir do texto em francês.

\section{Exposição durante a Feira de Ciências II FELUMEN.}


Foi estabelecido que os alunos se revezariam em duplas durante a Feira, para a apresentação do trabalho aos visitantes, conforme escolha de itens em um menu. A dupla responsável deveria ser capaz de apresentar qualquer parte do trabalho pedida. Fora do tempo designado para cada dupla, os alunos estariam ocupados com a exposição de trabalhos de outras disciplinas. Nem todos os alunos, entretanto, se apresentaram para expor, no decorrer da Feira, ficando a exposição assegurada por apenas três duplas. A filmagem dessas apresentações não permitiu a transcrição, devido ao intenso ruído do ambiente.

\section{Auto-avaliação}

Um questionário de auto-avaliação do trabalho foi aplicado no primeiro dia de aula subseqüente, após as três semanas de férias de julho, constando de perguntas sobre o progresso na habilidade de leitura, interesse do trabalho e um comentário espontâneo sobre o projeto. Antes do projeto, dez alunos consideravam sua capacidade de leitura em francês mediana ou regular, e três a consideravam ruim. Após o projeto, quatro julgavam ter uma boa capacidade de leitura em francês, oito uma capacidade mediana e apenas um manteve sua avaliação como ruim. A respeito da capacidade de encontrar em um texto determinada informação, quatro consideravam-na boa, seis mediana e três ruim. Após o projeto, dois consideravam ter excelente capacidade na busca de informações, seis boa, cinco mediana e nenhum ruim. Os demais aspectos da capacidade de leitura dividiram mais os resultados. Quanto à capacidade de reformular o texto, oito a consideravam mediana, quatro ruim e um péssima, antes do projeto. Depois do projeto, seis a consideravam boa, quatro mediana e um ruim. A própria habilidade de leitura em voz alta em português durante o projeto foi considerada excelente por um aluno, boa por seis, mediana por cinco e péssima por apenas um. $\mathrm{O}$ interesse de um trabalho interdisciplinar foi avaliado como ótimo/excelente por cinco 
alunos, bom por sete alunos e mediano por apenas um. Como vimos, a opinião sobre as próprias habilidades melhorou no decorrer do projeto na maioria dos alunos. Essa terá sido uma das causas da boa avaliação do trabalho como um todo por parte deles. Na resposta à pergunta livre "Dê sua opinião sobre o projeto", foram mencionados, como fatos positivos, o progresso na leitura em francês por sete alunos, a integração das disciplinas por sete alunos, a descoberta da habilidade de pesquisa em outras línguas por um aluno. Dois alunos consideraram apenas o aspecto agradável do trabalho e uma, finalmente, considerou o trabalho cansativo e excessivamente difícil, pois este era seu primeiro ano de francês.

\section{Avaliação posterior}

Nos últimos dias letivos de 2007, foi pedida à classe uma avaliação retrospectiva do projeto, ocorrido quase um ano e meio antes. Entre as respostas nota-se, de maneira geral uma impressão agradável. Os alunos descrevem sumariamente o desenrolar do trabalho, ressaltando a impressão positiva de compreensão dos textos lidos, mas alguns ressaltam que acreditam não ter conservado as habilidades adquiridas na ocasião.

\section{b.3. Apostila de Astronomia}

A participação do Colégio na Olimpíada Brasileira de Astronomia, no início de maio de 2006, estimulou a idéia da realização do primeiro projeto interdisciplinar Francês-Física. Esse projeto consistiria na produção de uma apostila a ser elaborada em português, por alunos do primeiro ano do Ensino Médio - para uso dos alunos de $5^{\mathrm{a}}$. a 8 . Séries, com o conteúdo indicado pela organização da Olimpíada, a partir de pesquisa 
em sites de língua francesa. O objetivo metodológico desse projeto seria o de desenvolver a habilidade de leitura em francês, em semi-autonomia, através da pesquisa na Internet em sites de língua francesa. Os passos seguidos para a realização da Apostila de Astronomia foram:

\section{Seleção de temas e divisão da classe em grupos}

Tanto a divisão quanto a escolha dos temas, entre os itens propostos pelo programa da Olimpíada, foi livre por parte dos alunos, resultando na seguinte composição das equipes:

1. Constelações e reconhecimento do céu (Adolfo e Felipe)

2. Corpos celestes (Paulo e Thiago)

3. A Terra como Planeta (Henrique)

4. História da Astronomia (Carolina e Catarina)

5. Origem do Universo: o Big Bang (Henrique e Raphael)

6. A conquista do espaço (Alessandra e Renata)

7. Satélites artificiais e sondas espaciais (Igor e Tony)

8. Foguetes (Felipe)

9. O corpo humano no espaço (Augusto e Tomás)

Dois alunos, Henrique e Felipe, após concluírem seus textos na dupla inicial, elaboraram individualmente um segundo texto.

\section{Pesquisa em sites de língua francesa}


Os alunos pesquisaram durante a aula de Francês, no laboratório de informática, a partir do portal de astronomia Astrosurf, no site indicado pelo professor de Física Astronomes, ou ainda através do site de busca Google. Os textos base foram tirados dos seguintes endereços:

- O corpo humano no espaço:

www.astrosurf.com/astrospace/hommespace.htm

www.astrosurf.com/luxorion/astronautique-malespace.htm

- Big Bang: a origem do universo:

www.astrosurf.com/astrospace/bigbang.htm

www.astrosurf.com/luxorion/cosmos-bigbang.htm

www.astrosurf.com/luxorion/cosmos-creation.htm

- A conquista do espaço:

http://physique.paris.iufm.fr/espace/5770.html

http://fr.wikipedia.org/wiki/Conqu\%C3\%AAte de 1\%27espace\#Les grandes da

tes

- História da Astronomia:

www.astronomes.com/c0 histoire/p000 main.html

http://www.astronomes.com/c0 histoire/p041 telescopes.html

www.astrosurf.com/luxorion/astro-histoire.htm

- Os corpos celestes: 
www.multimania.com/universus

http://www.astronomia-be.net/pages/prelude/introduction.html

- Constelações e reconhecimento do céu

www.astrosurf.com/mesetoiles/preambule.htm

www.astrosurf.com/luxorion/astro-enfant-ciel-constellations.htm

- Sondas espaciais:

Não declarado!

\section{Avaliação do projeto Apostila de Astronomia}

Acreditamos ter havido da parte dos alunos em geral, bom nível de compreensão dos textos consultados, mas é forçoso reconhecer que houve também nos textos em português imprecisões decorrentes sobretudo de problemas de ordem lexical, morfosintática e organização dos enunciados.

\section{b.4. Projeto A Guerra dos Cem Anos}

\section{Caracterização, objetivos e metodologia}

Esse trabalho foi realizado com a classe de $1^{\circ}$. Ano do Ensino Médio de 2005, como projeto interdisciplinar Francês-História. O objetivo metodológico, na disciplina Francês, foi o desenvolvimento da compreensão e autonomia da leitura em francês. Do 
ponto de vista interdisciplinar, visou-se a integração das disciplinas, e o desenvolvimento do uso da língua estrangeira como instrumento de trabalho e pesquisa. O trabalho iniciou-se com a pesquisa em francês, na Internet, de itens do tema proposto, em grupos de dois ou três alunos, no laboratório de Informática do colégio. O resultado foi apresentado em um texto escrito em português, ilustrado; dois dos grupos tiveram sua compreensão de leitura avaliada em uma leitura em voz alta, em português, gravada e transcrita; uma dessas transcrições foi analisada na monografia Descrições gramaticais para remediação de compreensão de leitura em FLE, apresentada para aproveitamento de crédito na disciplina Didática da gramática e educação linguageira, ministrada pelos professores Véronique Dahlet e Patrick Dahlet, no 2o. semestre de 2005.

\section{Avaliação do Projeto Guerra dos Cem Anos}

O desenrolar da pesquisa no laboratório de Informática foi bastante proveitoso. Os alunos mostraram em geral bastante desenvoltura na compreensão dos textos em francês, respeitaram a indicação de sites sugeridos e a exigência de consulta de menos dois textos. O texto em português revelou por parte de alguns alunos problemas de formulações e compreensão em francês, decorrentes, provavelmente, do emprego de tradutores automáticos que não souberam usar adequadamente, fazendo as adaptações ao contexto. O texto final apresentado foi tomado como avaliação bimestral da classe.

\section{b.5. Tratados e Grupos em Política Internacional}

\section{Caracterização, objetivos e metodologia}


Esse projeto, realizado no quarto bimestre de 2005, consistiu na pesquisa e apresentação em francês de um trabalho que já havia sido realizado, em português, para a disciplina Geopolítica. O grupo-classe tinha nove alunos, dos quais três obtiveram, ao final do semestre em questão, uma aprovação no DALF equivalente a B2; um aluno foi aprovado no nível equivalente a B1 e um outro ainda no nível A2. Tanto a pesquisa, quanto o trabalho propriamente dito para Geopolítica, foi realizado individualmente em casa, sem o auxílio do professor. O texto pronto foi apresentado pelos alunos na classe, tendo a exposição em francês sido considerada como nota principal do bimestre. $\mathrm{O}$ objetivo do projeto foi a exposição oral em francês, visando verificar a validade da escolha dos textos selecionados e da interpretação dada em francês. A utilização de trabalho já realizado para outra disciplina pretendeu tranqüilizar os alunos quanto à exposição dos textos e avaliação decorrentes.

\section{Avaliação}

O trabalho efetuado nos pareceu bastante produtivo, tendo a maioria dos alunos revelado grande interesse pela tarefa executada e muito bom ou bom nível de exposição oral.

\section{O projeto Histoire de la technologie maritime}

\section{a. Planejamento e organização}

O projeto Histoire de la technologie maritime foi feito em função da Feira de História e Geografia do Colégio de 2008, a II FeClio, cujo tema era De mar a mar : as grandes navegações. Ele consistiu basicamente em uma pesquisa na Internet de língua francesa, a respeito de temas escolhidos por duplas de alunos, seleção de textos e 
montagem de uma apresentação de Power Point em francês, para exposição em português ao público da Feira.

\section{a.1. Escolha do tema}

O tema do projeto foi escolhido pela professora, em conjunto com a professora coordenadora de História, Laura Pinca da Palma, a partir do tema geral do evento De mar a mar: as grandes navegações. Uma pesquisa prévia sobre o assunto na Internet de língua francesa mostrou que havia uma quantidade satisfatória de recursos disponíveis, acessíveis ao nível dos alunos e de boa qualidade. Nessa pesquisa, uma quantidade relativamente grande de palavras-chave foi testada, a partir da experiência lingüística da professora, não nativa, produzindo algumas delas resultados quase nulos ou mesmo inexistentes como, por exemplo, "histoire de la technologie maritime", "technologie des navigations" ou "technologie de la navigation", e outras de resultados variáveis como "explorateurs et navigateurs", "grandes découvertes", "grands explorateurs", “histoire des grandes découvertes”, “maritime”, "histoire maritime+enfants","histoire maritime”. Dentro dos resultados obtidos na pesquisa de cada uma dessas palavras chave, uma grande quantidade de sites foi acessada, produzindo uma lista de sugestões que será anexada adiante.

\section{a.2. Descrição do grupo classe}

A escolha da classe de $1^{\circ}$. ano do Ensino Médio para a execução do projeto procurou manter a linha de coerência de meu estudo, embora trate-se de uma classe que eu considero fraca em relação às protagonistas dos projetos anteriores. De fato, não há nenhum aluno que possua diploma de Delf/Dalf, o interesse e o rendimento do curso de Francês sempre foram abaixo da média. Tal situação de partida aparentemente adversa, entretanto, permitiu-me avaliar melhor as possibilidades pedagógicas do projeto. 
A classe possui onze alunos, todos entre quatorze e quinze anos, oito moças: Karysa, Stella, Gabriela, Inês, Caroline, Angel, Mariana e Jéssica e dois rapazes: Akira e Danillo (mais um terceiro que não cursa francês por seguir regime de classe especial). No dia do início do projeto, começou em experiência um rapaz novo, Rogério, que nunca havia estudado francês. As sete primeiras alunas, assim como o aluno Akira, estão no Colégio desde a educação infantil, tendo tido, portanto, cerca de oito ou nove anos de curso. Jéssica está em seu segundo ano de Colégio, tendo sido reprovada no $1^{\circ}$. ano Médio em 2007. Danillo chegou ao Colégio no início do ano letivo de 2008.

\section{a.3. Testagens preliminares}

Entre os alunos antigos, a compreensão de leitura é a habilidade que foi mais focada, as diferenças de nível de compreensão podem ser avaliadas por meio dos testes abaixo, aplicados na primeira semana de aulas, no dia 15.02.08, e na semana anterior ao início do projeto, em 08.04.08.

\section{Teste de leitura aplicado em 15.02.08}

Esse teste refere-se a um exame de nível de conhecimento nas diversas disciplinas do Colégio. A participação é obrigatória, mas os resultados não são levados em conta para efeito de aprovação, servindo apenas como um instrumento de avaliação prévia para controle do colégio e do professor.

\begin{tabular}{|l|c|}
\hline \multicolumn{2}{|l|}{ Resultados } \\
\hline Angel & 9,0 \\
\hline Caroline & 5,4 \\
\hline
\end{tabular}




\begin{tabular}{|l|c|}
\hline Danillo & 0,0 \\
\hline Gabriela & 8,4 \\
\hline Inês & 7,2 \\
\hline Jéssica & 6,2 \\
\hline Akira & 6,0 \\
\hline Karysa & 6,3 \\
\hline Mariana & 8,8 \\
\hline Stella & 6,2 \\
\hline
\end{tabular}

\section{Teste de leitura aplicado em 08.04 .08}

O novo teste utilizou uma atividade de leitura em Internet proposta por Custers, Pâquier e Rodier (2004 : 57). Trata-se de uma visita virtual à Bretanha, através do site www.asteria.fr, em que frases descritivas devem ser associadas ao nome de diversas localidades. Embora contenham informações presentes no site, as frases nunca correspondem exatamente aos termos encontrados. Essa testagem não se revelou útil para a diferenciação das habilidades de leitura, pois oito dos dez alunos participantes obtiveram a mesma nota, acertando todas as questões possíveis (10/14: das 14 questões propostas na atividade, 4 pediam informações que não constavam mais do site). Em todo caso, o teste mostrou um bom nível geral da turma em leitura em Internet.

\section{a.4. Investigação dos hábitos de leitura}

Em 08.04 foi igualmente aplicado o questionário Leitura em Internet $e$ aprendizagem de FLE, para as turmas do Primeiro e do Segundo Médio, para efeito de comparação. A turma do $2^{\circ}$. Médio participou do Projeto Russie, no ano anterior, 
apresentado na I FeClio, falando sobre a geografia e história da Rússia. Duas perguntas acrescentadas a esse questionário, que fora aplicado a todos os alunos do Ensino Fundamental II e Ensino Médio do Colégio no ano de 2004 (resultados mais adiante), investigam os hábitos de pesquisa em Internet, sob efeito ou não do treinamento proporcionado pela execução dos Projetos. Os alunos que participaram do Projeto no ano anterior têm respostas mais precisas e seguras, e evitam os procedimentos menos vantajosos como o uso de tradutores automáticos para a compreensão de leitura.

\section{a.5. Ensino da metodologia de pesquisa em Internet: Guia de pesquisa em FLE na Internet}

O estudo da bibliografia, sobretudo daquela referente aos TPE (travaux personnels encadrés) franceses, recomenda vivamente uma instrução específica para a pesquisa em Internet (cfr. Pantanella, 2001 :10; Pouts-Lajus, 2001 : 14; Beaufils, Blondel, 2001 : 31; Unguen, 2001 : 60). Atendendo tal recomendação, foi preparada uma exposição em Power Point, intitulada Guia de pesquisa em FLE na Internet, versando sobre os seguintes pontos: natureza da Internet, vantagens e perigos da pesquisa em Internet, oportunidade do aprendizado da metodologia de pesquisa, etapas de um projeto de pesquisa e estratégias de leitura em FLE. A exposição consumiu cerca de uma hora e meia, na sala de Informática, no dia 15.04.08. A íntegra dessa exposição se encontra no anexo digital.

\section{a.6. Divisão em duplas}


Após a apresentação da metodologia da pesquisa em Internet, foi proposto o projeto, em termos de formas de apresentação, de divisão das duplas e de escolha dos subitens do tema geral. A divisão das duplas foi a seguinte:

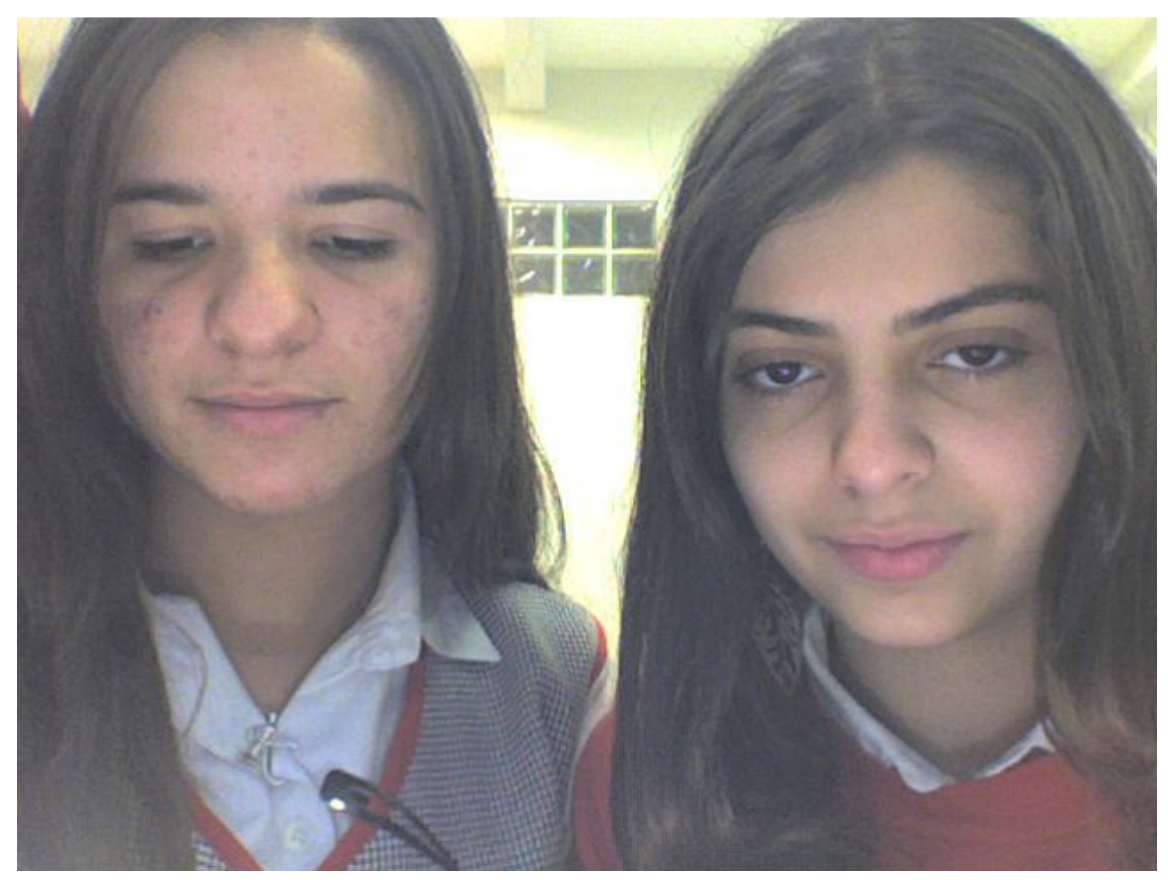

\section{Figura 5 - Karysa e Caroline}

- Karysa e Caroline: Karysa lê com relativa facilidade e tranquilidade (6,3 no teste de leitura) ; Caroline, embora tenha bom desempenho nas provas $(5,4$ no teste, porque não representava uma avaliação com consequiências na nota), queixa-se em todas as situações de avaliação de que «não sabe nada de francês » e insiste no uso do tradutor automático. 


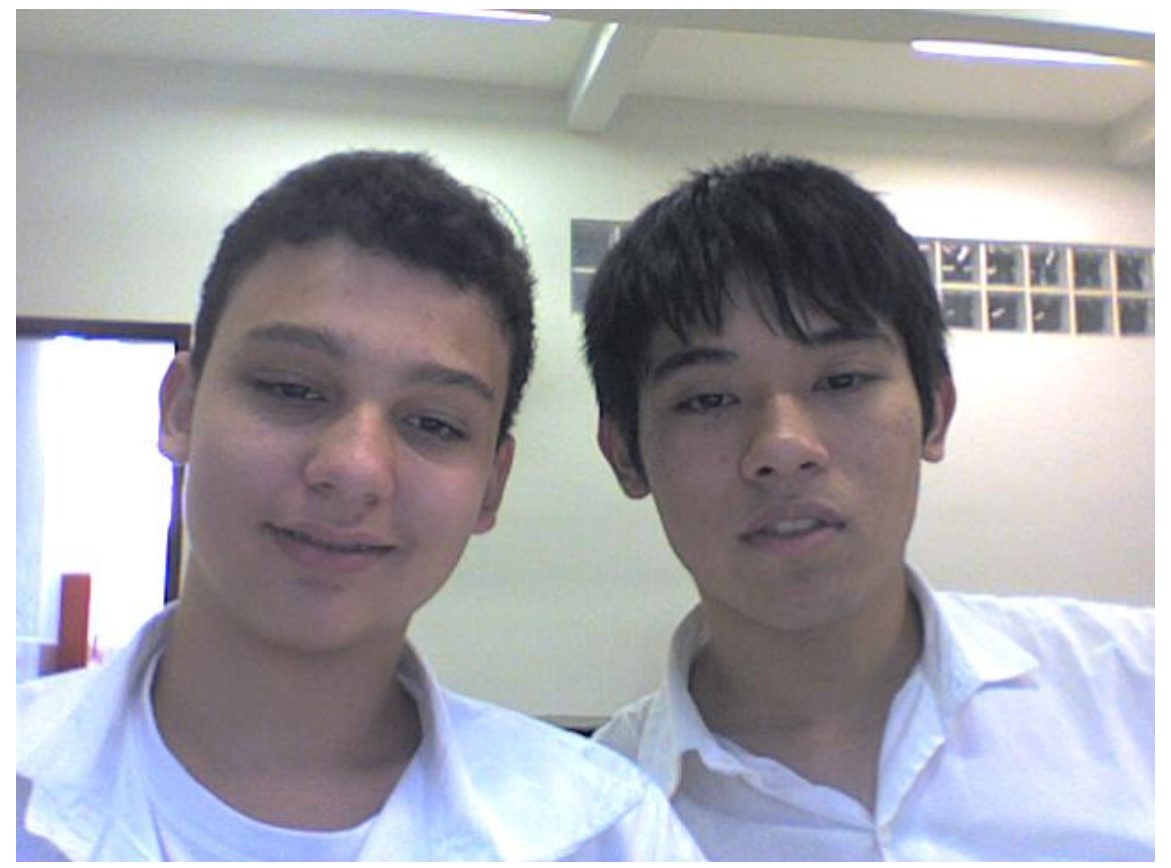

Figura 6 - Danillo e Akira

- Danillo/Akira : Akira tem feito grandes progressos em Francês (6,0 no teste de leitura no início do ano) e mostra também grande interesse em arte e tecnologia. Danillo começou a estudar Francês neste ano mas mostra-se bastante interessado e colaborativo.

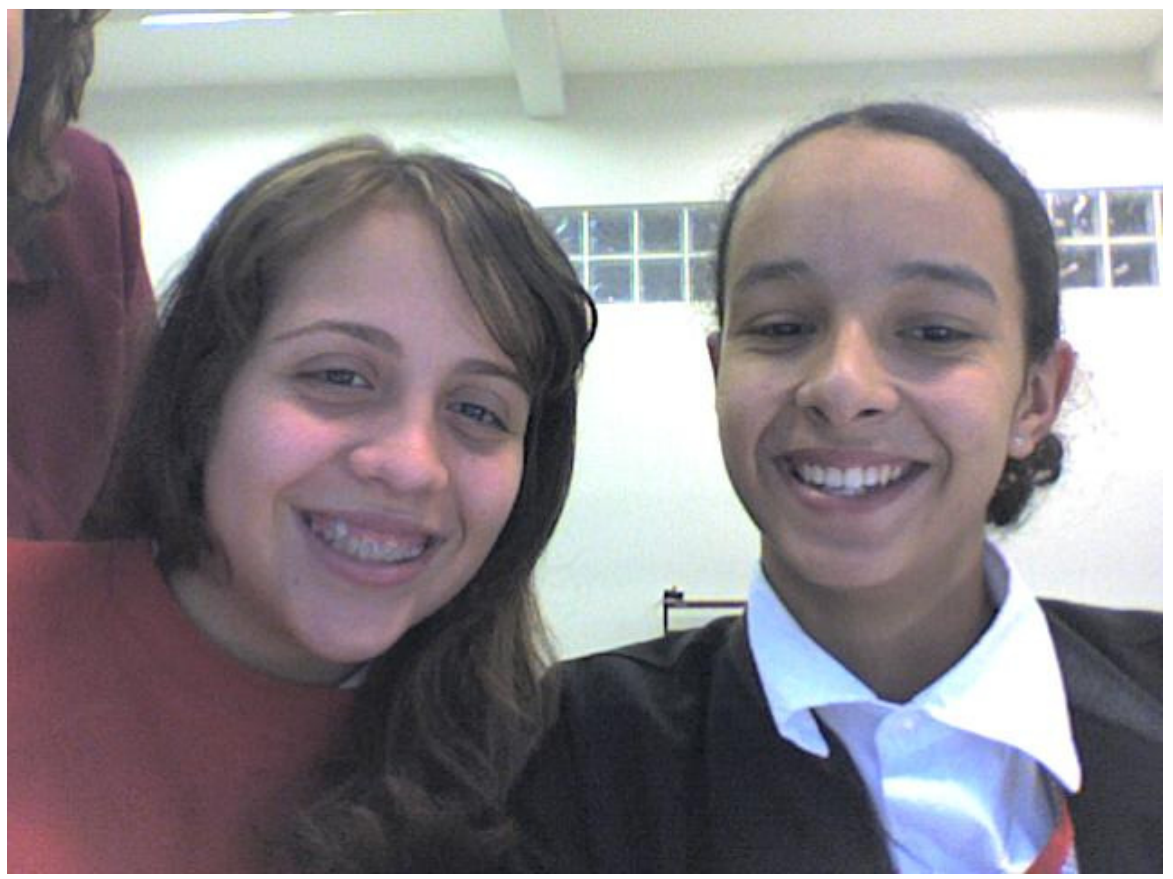


- Stella/Jéssica : Ambas tiveram nota 6,2 no teste de leitura. Stella é aluna do colégio há muitos anos, mas normalmente se mostra desinteressada em Francês. Jéssica mostra mais interesse mas, tendo vindo de escola pública, foi reprovada no 1o.ano médio em 2007.

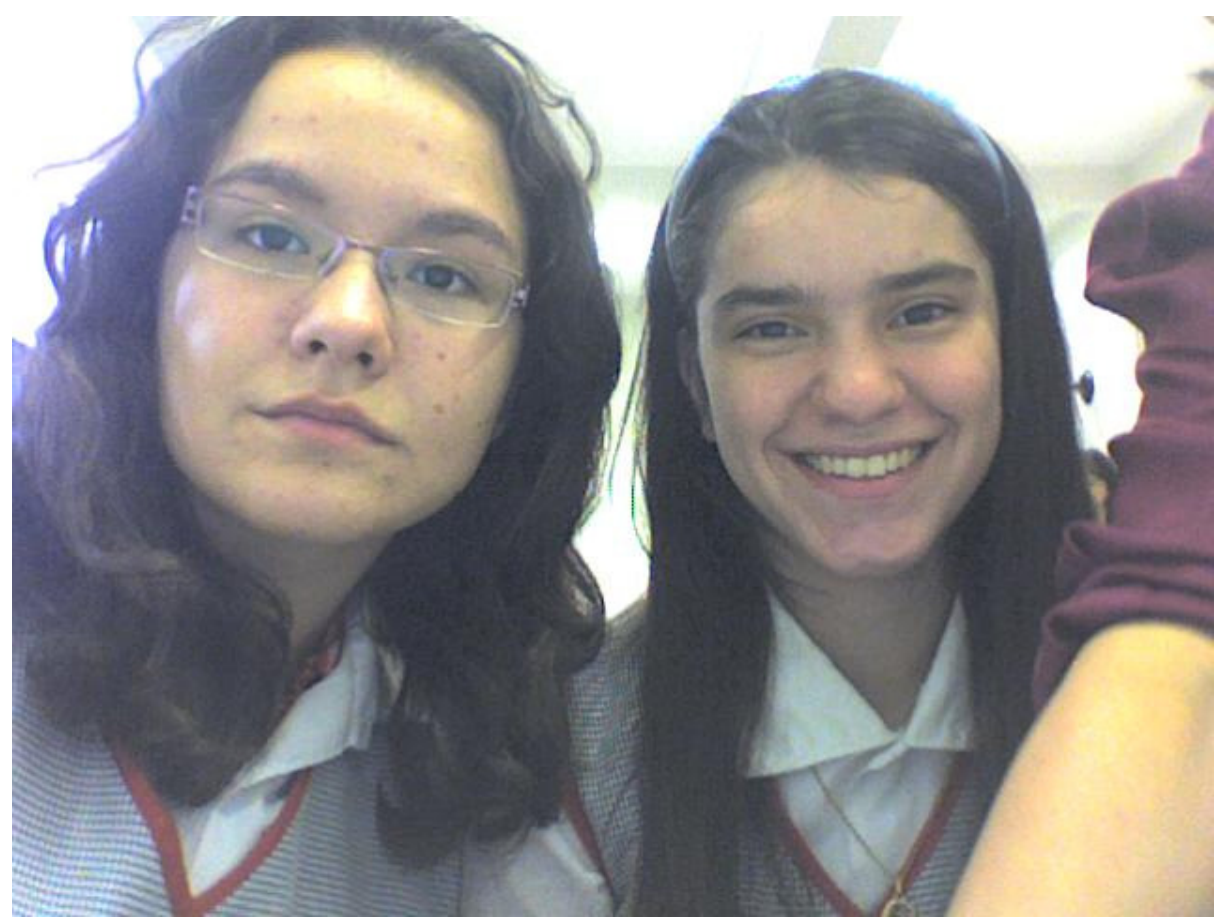

Figura 8: Gabriela e Inês

Gabriela/Inês : A dupla reuniu duas boas leitoras (notas 8,4 e 7,2), bastante interessadas e ativas. 


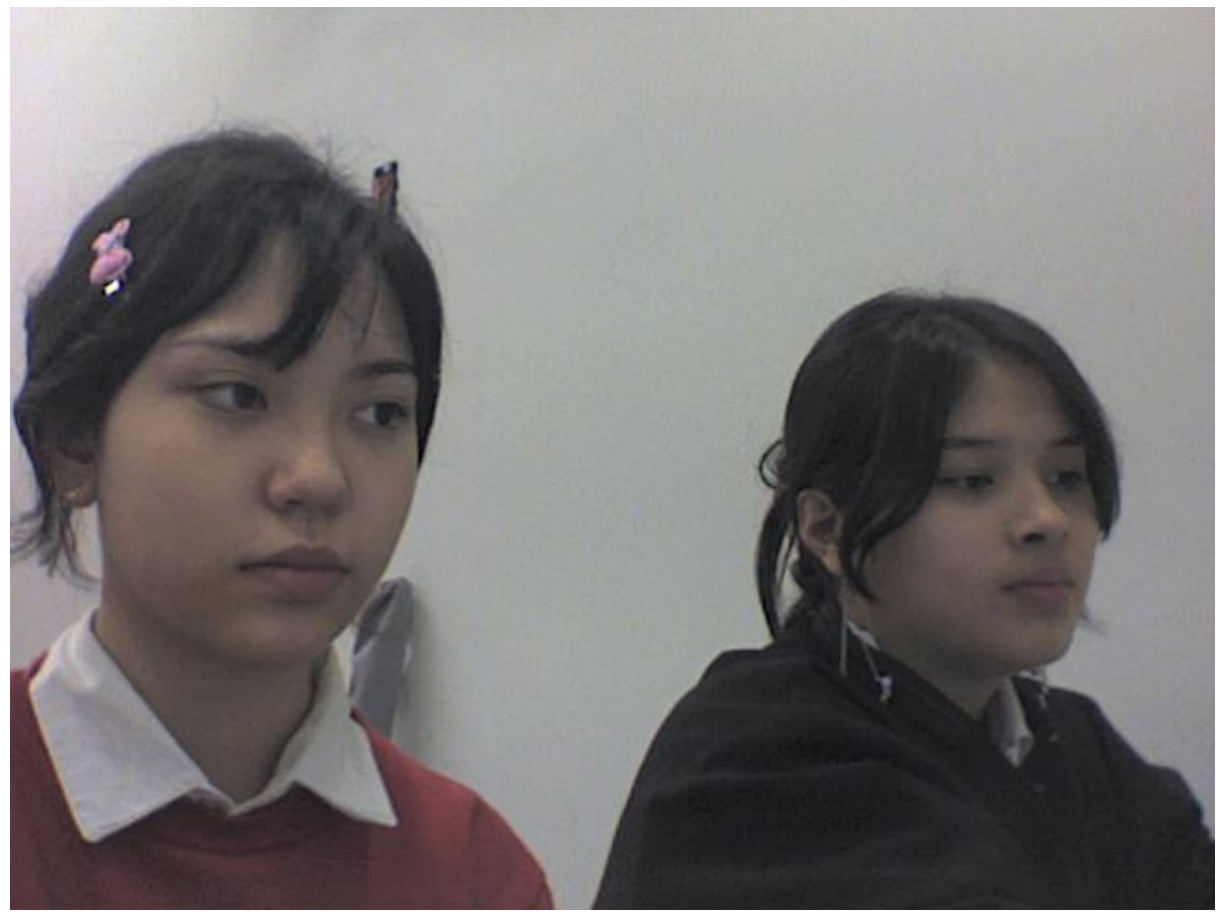

Figura 9: Mariana e Angel

Mariana/Angel : excelentes alunas, obtiveram as melhores notas no teste de leitura, respectivamente 8,8 e 9,0 .

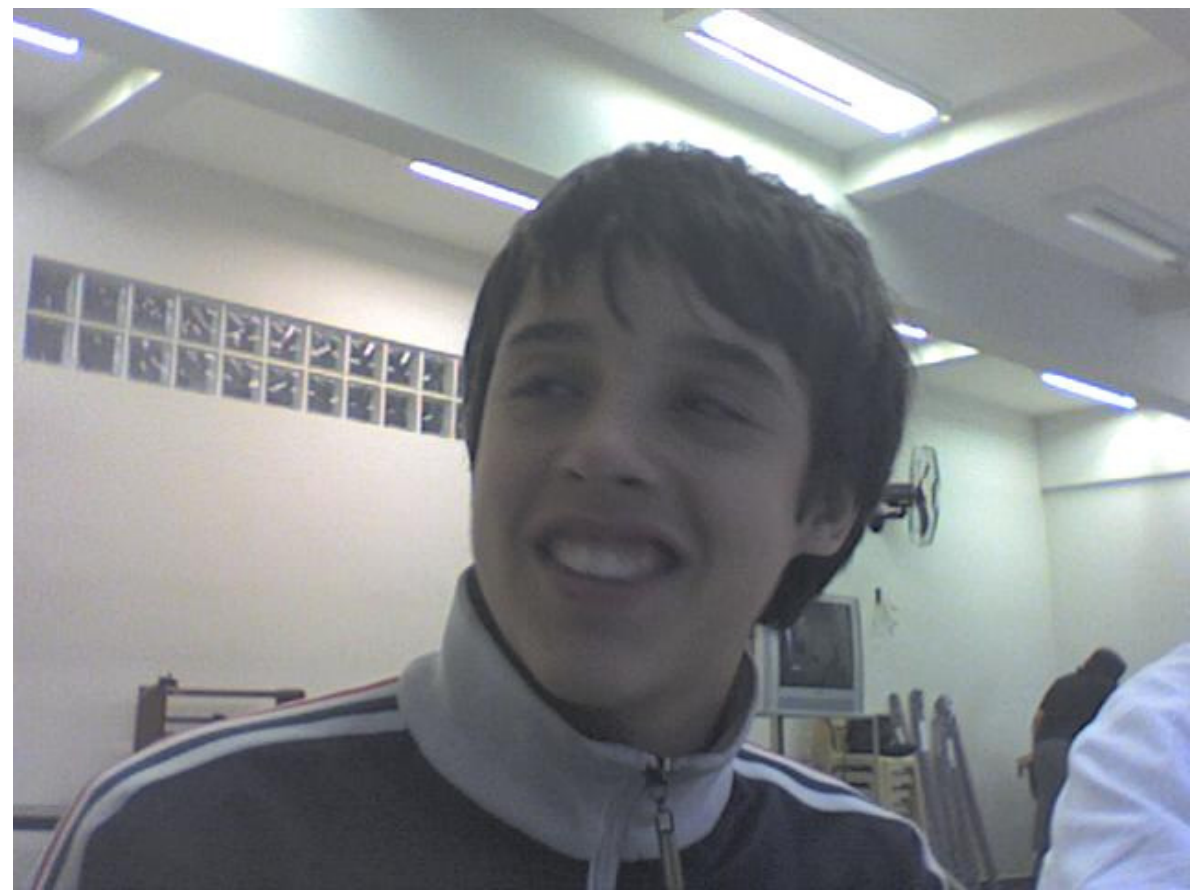

Figura 10: Rogério 
Rogério, o aluno novo, pesquisou sozinho, com a ajuda da professora.

\section{a.7. Detalhamento do tema}

Nesse ponto, houve alguma negociação.

\section{La navigation ou comment s'orienter en mer}

Este item, considerado central pela professora foi rejeitado pelas duplas e finalmente aceito pelo aluno em experiência, Rogério, que pesquisava com a ajuda da professora.

\section{La construction des bateaux}

Escolhido pela dupla Karysa/Caroline.

\section{La propulsion navale}

Tema escolhido pela dupla de meninos.

\section{Les finalités de la marine}

Stella e Jéssica escolheram este tema, embora não tivesse idéias claras a respeito de como desenvolvê-lo.

\section{Les marins}

Esse item, assim como o anterior, não existiam no projeto original. Foi aceito por insistência das alunas Inês e Gabriela. A tentativa de dar-lhe um enfoque ligado à tecnologia teve um resultado um tanto confuso. 


\section{La cartographie}

Mariana e Angel tiveram certa dificuldade no início da pesquisa, porém, após alguma ajuda para a definição do tema, encontraram ótimas fontes pesquisando por si próprias.

A lista das duplas e dos temas escolhidos foi escrita na tela grande da professora e anotada pelos interessados.

\section{b. Execução e apresentação}

\section{b.1. Pesquisa na Internet e confecção da apresentação em Power Point}

1a. sessão de pesquisa

No próprio dia da escolha dos temas, com a alocação de uma aula de História e duas de Francês, um período final de 30 minutos foi usado para o início da pesquisa em Internet. Como não estava previsto esse início, foi indicado como único recurso o site http://papy43-aufildutempsquipasse.blogspot.com/2008/01/grands-

explorateurs.html, dirigido por um professor francês de História e Geografia, que propõe uma lista de sites com conteúdos adequados para seu público, colegiais franceses, e para seu tema, as grandes viagens de descoberta. As reações foram bastante variadas. Algumas frases ouvidas: "Professora Lúcia, esse texto não pode ser lido entendidamente" (Stella); "Professora, posso ser bem sincera? Não estou entendendo nada" (Caroline) ou ainda, "Professora, vai gastar dias pesquisando isso daqui!!!" (Angel). Por outro lado, Akira e Danillo, pesquisando a propulsão naval, começaram pela Wikipédia, encontrando imediatamente um artigo sobre o tema. Embora tenham 
sido lembrados de que deveriam necessariamente consultar ao menos dois sites, eles já se puseram a selecionar frases para a apresentação em Power Point.

\section{$2^{\mathrm{a}}$. sessão de pesquisa}

Realizada dois dias após a primeira sessão, em 17.04.08, a segunda sessão foi realizada no horário de aulas de História e Desenho, com a duração de cerca de três horas. Para essa sessão, os alunos já contavam com a lista (Anexo 1), de sites selecionados pela professora, enviados por e-mail para a classe. Alguns alunos, entretanto, não chegaram sequer a abrir essa lista, contentando-se com os recursos encontrados na pesquisa própria.

\section{$3^{\text {a }}$. sessão de pesquisa}

Em 22.04.08, a pesquisa pode prosseguir no horário das aulas do $2^{\circ}$. Médio, que preparava outros projetos para a FeClio, e no horário do $1^{\circ}$. Médio, totalizando três horas. Houve uma primeira tentativa de gravação da leitura em voz alta dos textos, que não se efetivou por falha do equipamento.

\section{$4^{\mathrm{a}}$. sessão de pesquisa}

Na quinta-feira, 24.04.08, foi realizada nas aulas de História, e prosseguiu à tarde no horário da aula de Ensino Religioso, com cerca de duas horas e quinze minutos. Durante o desenrolar da pesquisa, a professora entrevistou as duplas a respeito do trabalho, obtendo muitas respostas interessantes a respeito do processo de leitura e das 
estratégias de pesquisa (transcrição da entrevista no Anexo 2). O comentário da entrevista será feito adiante.

\section{$5^{\mathrm{a}}$. e última sessão}

$\mathrm{Na}$ véspera da Feira, sexta-feira 25.04.08, essa sessão ocupou as aulas de Informática (45 min.), uma das aulas de Biologia, cedida pela professora a pedido (mais 45 minutos) e uma parte do horário de almoço (1 hora). A conversão do arquivo do programa utilizado na rede de computadores do Colégio (Windows 97), para um computador que pudesse ser transportado para o auditório, onde teria lugar a apresentação do projeto durante a FeClio, teve que ser feita na manhã de sábado, empregando cerca de meia hora.

Em termos de consumo de tempo, temos, portanto, cerca de doze horas no laboratório de Informática (11 e 45 minutos), mais uma hora para a escolha dos temas e divisão dos grupos e ainda uma hora e meia para a aula de metodologia da pesquisa em Internet. Esse período de trabalho pôde ser alocado em apenas duas semanas, graças ao esforço concentrado do Colégio com vistas à FeClio. Em um ritmo de trabalho mais espaçado, haveria o benefício de maior reflexão, mas o tempo empregado tenderia a ser maior. Não está incluído também o planejamento, que empregou um número grande e indefinível de horas, sobretudo na preparação da aula de metodologia de pesquisa e na busca de bibliografia em Internet para fornecer aos alunos. Entre as atividades previstas, não pode ser realizada a leitura conjunta de um texto sobre o tema, com o objetivo de adquirir e ativar vocabulário. O texto escolhido para essa atividade foi utilizado posteriormente para a avaliação de leitura em voz alta e nova testagem. A leitura em voz 
alta em português, para avaliação das dificuldades de compreensão e estratégias de leitura, só pode ser realizada após a FeClio, em 29.04.08 (Ver transcrição no Anexo 3). Outro procedimento que constou de projetos anteriores e não foi realizado por falta de tempo é a leitura conjunta de todo o texto da exposição, para permitir a toda a classe apresentar qualquer item do trabalho. Por isso, na exposição durante a FeClio, cada dupla se limitou a expor seu próprio trabalho.

\section{b.2. Apresentação do Projeto durante a II FeClio}

O Projeto foi apresentado ao público da II FeClio, realizada em 26.04.08, sábado, das 10 às 15 horas. O público da Feira consistia basicamente nas famílias, vindas para a Reunião de Pais e Mestres bimestral, marcada para o horário da manhã, no Colégio, além de um bom número de adolescentes do bairro, convidados pelos próprios alunos. A FeClio realiza-se no pátio coberto e no auditório do Colégio, organizada em pequenos stands, nos quais os grupos de alunos expõe seus trabalhos, explicando-os a pedido dos visitantes. O Projeto Technologie Maritime foi exposto no telão do Auditório por duplas que se revezavam durante o período da Feira, explicando em português o texto que era apresentado em francês. Uma amostra dessas exposições foi filmada, mas o intenso ruído da Feira não permite a transcrição dessas gravações.

\section{c. Atividades de avaliação}

Durante a fase de execução do projeto várias atividades de avaliação foram realizadas, entre elas: a entrevista com as duplas, a respeito das estratégias de pesquisa e leitura; a leitura em voz alta, pelas duplas, de um texto de mesmo tema do projeto; a 
auto-avaliação escrita, individual; a leitura pelas duplas do texto da própria apresentação; além da própria realização da apresentação em Power Point e de sua exposição pelas duplas no decorrer da Feira.

\section{d. A retomada}

Segundo Tardif (2002 : 24) o trabalho com projetos deve ser seguido de “intervenções levando à descontextualização e à organização hierárquica das aprendizagens $^{174 ” . ~ N e s s a ~ i n t e n c ̧ a ̃ o, ~ f o r a m ~ r e a l i z a d a s ~ a l g u m a s ~ a t i v i d a d e s ~ n a s ~ s e m a n a s ~}$ que seguiram a apresentação do projeto: a primeira delas foi a retomada para reflexão da aula Guia de pesquisa em FLE na Internet, na semana seguinte, um novo projetorelâmpago de pesquisa, preparado em uma sessão de uma hora e meia.

Em 27.05.08, um mês após a apresentação do projeto Histoire de la Technologie Maritime durante a FECLIO, a professora propôs uma nova sessão de pesquisa, na qual cada dupla refaria a pesquisa trocando os temas com uma outra dupla. A proposta foi recebida com protestos pela classe, pois, alegavam eles, "a gente não agüenta mais esse assunto de barcos”. Para salvar a idéia, foi combinado que cada dupla faria um pequeno projeto de pesquisa, com duração de apenas uma aula de uma hora e meia, sobre o assunto que parecesse à dupla mais interessante, desde que o tema fosse comunicado previamente à professora, seguindo os parâmetros do projeto Technologie, ou seja, pesquisa em francês e exposição do tema em Power Point. O resultado desse projetorelâmpago pode ser apreciado no Anexo Digital.

\footnotetext{
174 “des interventions portant sur la décontextualisation et l’organisation hiérarchique des apprentissages”
} 


\section{Discussão e avaliação do projeto}

\section{a. Análise da produção dos alunos}

A avaliação dos resultados do projeto será feita tanto em termos de um resultado verificável na compreensão de leitura e na aquisição de estratégias de pesquisa em Internet, quanto de apreciações positivas do projeto e da autoavaliação, na medida em que estas representam ganhos na motivação ${ }^{175}$.

Compararemos, portanto, os resultados do Questionário de Avaliação do Projeto $^{176}$, com a entrevista realizada com as duplas, no dia 24.04.08, e os comentários da primeira sessão de pesquisa, acontecida em 15.04.08, introduzindo em seguida a análise dos textos da apresentação de Power Point. Os comentários, anotados ao vivo, mostram o encontro dos alunos com seu objeto de leitura:

"Algumas frases ouvidas: "Professora Lúcia, esse texto não pode ser lido entendidamente" (Stella); "Professora, posso ser bem sincera? Não estou entendendo nada." (Caroline) ou ainda, "Professora, vai gastar dias pesquisando isso daqui!!!" (Angel). Por outro lado, Akira e Danillo, pesquisando a propulsão naval, começaram pela Wikipédia, encontrando imediatamente um artigo sobre o tema. Embora tenham sido lembrados de que deveriam necessariamente consultar ao menos dois sites, eles já se puseram a selecionar frases para a apresentação em Power Point."

Vemos que o primeiro impacto do trabalho de leitura foi um tanto negativo, embora esse efeito não tenha muita relação com a opinião que os alunos tinham de sua capacidade de leitura e com a sua pontuação em testagem anterior ao projeto. Assim,

\footnotetext{
${ }^{175}$ BOGAARDS (1991: 55), já citado.

176 Texto constante do anexo 13
} 
Danillo, Mariana, Angel, Stella e Jéssica consideravam-se fracos em leitura, sendo que Danillo entregou sua prova de leitura no começo do ano (três meses antes do projeto) em branco, Mariana e Angel tiveram respectivamente 9,0 e 8,8, as maiores notas da classe e Stella e Jéssica tiveram 6,2, isto é, notas abaixo da média. A nota mais baixa da classe, Caroline, avaliava sua leitura como mediana e Karysa, apenas um décimo acima de Stella e Jéssica, considerava-se uma boa leitora. Inês e Gabriela fizeram autoavaliações conforme suas notas. Todos os alunos, no entanto, acreditam ter melhorado sua capacidade de leitura no decorrer do projeto, exceto Gabriela, que já se considerava uma boa leitora. Acreditamos poder assim afirmar, com base nesses resultados, que, embora a avaliação da própria capacidade nem sempre esteja baseada em critérios objetivos, ela é importante na maneira de abordar um trabalho e foi beneficiada pelo projeto em todos os casos apresentados.

\begin{tabular}{|c|c|c|c|c|c|}
\hline & $\begin{array}{l}\text { Resultados } \\
\text { em testagem } \\
\text { anterior }\end{array}$ & \begin{tabular}{|l|} 
Autoavaliação \\
anterior em \\
leitura
\end{tabular} & $\begin{array}{l}\text { Atitude ao } \\
\text { abordar a leitura }\end{array}$ & $\begin{array}{l}\text { Autoavaliação } \\
\text { em entrevista }\end{array}$ & $\begin{array}{l}\text { Autoavaliação } \\
\text { posterior ao } \\
\text { projeto }\end{array}$ \\
\hline Akira & 6,0 & mediana & decisão & $\begin{array}{l}\text { Razoavelmente } \\
\text { bem }\end{array}$ & boa \\
\hline Danillo & 0,0 & fraca & decisão & Mais ou menos & mediana \\
\hline Mariana & 9,0 & fraca & & $\begin{array}{l}\text { Tudo a gente } \\
\text { perguntava }\end{array}$ & mediana \\
\hline Angel & 8,8 & fraca & desânimo & $\begin{array}{l}\text { Razoavelmente } \\
\text { razoável }\end{array}$ & mediana \\
\hline Caroline & 5,4 & mediana & desânimo & Tá médio & boa \\
\hline Karysa & 6,3 & boa & & $\begin{array}{l}\text { Dá pra entender } \\
\text { mas não para } \\
\text { traduzir }\end{array}$ & ótima \\
\hline Gabriela & 8,4 & boa & & $\begin{array}{l}\text { Dá para } \\
\text { entender }\end{array}$ & boa \\
\hline Inês & 7,2 & mediana & & $\begin{array}{l}\text { Texto era muito } \\
\text { fácil }\end{array}$ & boa \\
\hline Stella & 6,2 & fraca & desânimo & $\begin{array}{l}\text { Dá para } \\
\text { entender }\end{array}$ & mediana \\
\hline Jéssica & 6,2 & fraca & & $\begin{array}{ll}\text { só com } & \text { o] } \\
\text { tradutor } & \text { ou } \\
\text { professora } & \\
\end{array}$ & mediana \\
\hline
\end{tabular}

Tabela 7: Avaliação e autoavaliação em leitura 
Outro dado que ressalta do quadro acima é a diversidade de "pontos de partida" subjetivos com relação à leitura. Essa situação deverá propiciar diferentes maneiras de ler. Examinaremos algumas delas.

A habilidade de pesquisa em Internet foi objeto de questões na autoavaliação e na entrevista. As respostas obtidas mostram alguns fatos interessantes.

\begin{tabular}{|c|c|c|c|}
\hline & \multicolumn{2}{|c|}{ Capacidade de pesquisa } & \multirow[t]{2}{*}{ Algumas afirmações sobre a pesquisa } \\
\hline & Antes & Depois & \\
\hline Akira & ótima & ótima & \multirow{2}{*}{$\begin{array}{l}\text { Akira: Usando primeiramente o Google. Abri um } \\
\text { monte de sites e escolhi um pelo título geral do } \\
\text { texto (...) para ler. }\end{array}$} \\
\hline Danillo & ótima & ótima & \\
\hline Mariana & mediana & boa & \multirow{2}{*}{$\begin{array}{l}\text { Mariana: Procurei um tempão, um tempão, aí me } \\
\text { deu na cabeça procurar "histoire de la } \\
\text { cartographie". No Google, normal, sem opção } \\
\text { francês, só com a frase. }\end{array}$} \\
\hline Angel & fraca & mediana & \\
\hline Caroline & fraca & mediana & \multirow{2}{*}{$\begin{array}{l}\text { Caroline: A gente pesquisou primeiro na } \\
\text { Wikipédia, porque sempre tem coisas. Depois nos } \\
\text { que a professora indicou. }\end{array}$} \\
\hline Karysa & fraca & mediana & \\
\hline Gabriela & mediana & mediana & \multirow{2}{*}{$\begin{array}{l}\text { Gabriela: Depois de pesquisar no Google e não } \\
\text { achar nada, resolvemos partir para os links que a } \\
\text { professora mandou. Mas acabei usando para } \\
\text { começar um site que não estava nos links. } \\
\text { Inês: Eu fui direto aos links e achei um lá que } \\
\text { tinha tudo. O "Des bateaux". }\end{array}$} \\
\hline Inês & mediana & boa & \\
\hline Stella & boa & boa & \multirow{2}{*}{$\begin{array}{l}\text { Stella: A gente perguntou para a professora e ela } \\
\text { indicou. Aí a gente abriu. O outro não tinha } \\
\text { nada. [O outro site que a professora indicou] } \\
\text { Jéssica: A gente não conseguiu entender, então } \\
\text { pegou na Wikipédia mesmo. }\end{array}$} \\
\hline Jéssica & mediana & mediana & \\
\hline
\end{tabular}

Tabela 8: Capacidade de pesquisa em Internet

Cinco das alunas consideram ter progredido quanto a sua capacidade de pesquisa em Internet, três alunas não consideram ter progredido, assim como os dois alunos, os quais acreditavam já ser ótima sua capacidade de pesquisa em Internet. Aparentemente, o conceito positivo a respeito da própria habilidade em Internet favoreceu a atitude dos alunos ao abordarem o projeto.

Os alunos pesquisaram de maneira geral partindo do site de buscas Google, ou diretamente na Wikipédia - a enciclopédia "cooperativa” da Internet - com opção pela 
língua francesa. As palavras-chave foram o próprio título de seu trabalho, ou outras sugeridas pela professora. Um dado conhecido dos professores que trabalham com Internet é a resistência dos alunos em seguir sugestões de endereços, sem antes pesquisar por conta própria.

"Professora: Como vocês encontraram?

Akira: Usando primeiramente o Google. Abri um monte de sites e escolhi um pelo título geral do texto.

Professora: Um para ler?

Akira: É, para ler, para ver se tinha o que eu queria”.

ou ainda:

Professora: Por que escolheram aquele site?

Karysa: Ele tem informações melhores.

Carol: É melhor para resumir o texto.

Professora: Como é que vocês sabem?

Carol: A gente pesquisou primeiro na Wikipédia, porque sempre tem coisas. Depois nos que a professora indicou.

Karysa: Porque a professora indicou.

O resultado final das pesquisas mostra bastante eficiência, justificando a opinião positiva sobre a própria capacidade ${ }^{177}$. Uma pesquisa particularmente trabalhosa pode resultar em um achado precioso:

\footnotetext{
${ }^{177}$ Essa é a conclusão de Beaufils e Blondel (2001 : 31), referente unicamente à habilidade de pesquisa em Internet, já que eles tratam de pesquisas em francês língua materna: "os alunos são capazes de encontrar documentos e dentro desses documentos, as respostas que eles consideram adequada"
} 
"Mariana: Procurei um tempão, um tempão, aí me deu na cabeça procurar "histoire de la cartographie”

Professora: Pesquisou como?

Mariana: No Google, normal, sem opção francês, só com a frase.

Professora: Por que escolheram esse site?

Angel: Esse site tem bastante conteúdo.

Mariana: Bastante conteúdo e bastante imagem. A gente não precisou procurar imagem."

De fato, o site em questão é o do $\mathrm{BNF}^{178}$, que tem uma página muito grande e bem feita sobre a cartografia, executada por ocasião de uma grande exposição de mapas nessa instituição. Na comparação abaixo ${ }^{179}$, o texto-base copiado da Internet é o trecho que foi utilizado diretamente para compor o texto das alunas, ele representa apenas uma pequena parte do que foi lido. O texto é tomado de http://expositions.bnf.fr/cartes/.

Dès l'Antiquité, les hommes ont cherché à représenter leur territoire et à mémoriser des itinéraires.
Dès l'Antiquité, les hommes ont cherché à représenter leur territoire et à mémoriser des itinéraires.

Não compreendendo a palavra conçoit do texto original, as alunas pedem à professora um sinônimo e a substituem. A substituição das formas verbais (élaborent no lugar de vont élaborer e jettent no lugar de jeter) é também sugestão da professora.

\footnotetext{
${ }^{178}$ BNF: Banque Nationale Française

${ }^{179}$ Nas tabelas de análise dos textos, a coluna direita corresponde ao texto selecionado pelos alunos, a partir do texto-base disponível no site consultado, o qual está transcrito na coluna à esquerda. A parte marcada em itálico, no texto-base, corresponde àquela selecionada pelos alunos; na coluna da direita, os caracteres em negrito correspondem a palavras ou frases acrescentadas pelos alunos ao texto inicial. Cada célula da tabela corresponde a um slide, sendo que a extensão do texto escolhido está condicionada ao suportado pelo formato do slide.
} 
Les Grecs vont élaborer un système de représentation du monde et jeter les bases de la cartographie. Vers 650 avant Jésus-Christ, Thalès de Millet conçoit déjà la rotondité de la Terre, ce que confirmera quelques siècles plus tard Aristote en s'appuyant sur l'image des bateaux disparaissant progressivement à l'horizon comme aspirés par la mer.

\section{Les Grecs}

Les Grecs élaborent un système de représentation du monde et jettent les bases de la cartographie.

Vers 650 avant J.-C., Thalès de Millet imagine déjà la rotondité de la Terre, ce que confirmera plus tard Aristote en s'appuyant sur la disparition progressive des bateaux à l'horizon.
Tout le savoir grec est résumé au IIe siècle après Jésus-Christ par un astronome et géographe grec, Ptolémée, né à Alexandrie. Dans la vision de Ptolémée, la Terre ronde s'inscrit au centre de l'univers. Un quart seulement $d u$ globe est habité, c'est l'œcoumène, isolé par un océan infranchissable.

\section{Ptolémée}

$\mathrm{Au}$ IIe siècle après $\mathrm{J}$.-C, un astronome et géographe grec, Ptolémée, croit la Terre ronde et inscrite au centre de l'univers. Un quart seulement du globe est habité, c'est l'œcoumène, isolé par un océan infranchissable.
Au Moyen Âge, en Occident, la vision chrétienne prédomine et les mappemondes médiévales mettent en scène une représentation symbolique.

\section{Moyen Âge}

$\mathrm{Au}$ Moyen Âge, en Occident, la vision chrétienne prédomine et les mappemondes médiévales mettent en scène une représentation symbolique
Les mappemondes arabes privilégient deux types de représentations : l'une de la terre habitée dans la tradition de Ptolémée, l'autre consacrée au monde musulman rassemblé autour de La Mecque.

\section{Les arabes}

Les mappemondes arabes représentent la terre habitée dans la tradition de Ptolémée ou mettent en scène le monde musulman rassemblé autour de La Mecque.
Les Arabes reprennent les travaux des Grecs et font revivre la tradition scientifique de la cartographie. Au XIIe siècle le géographe arabe al-Idrîsî établit une carte du monde et rassemble l'essentiel du savoir géographique de son temps.

\section{Al-Idrîsî}

$\mathrm{Au}$ XIIe siècle le géographe arabe al-Idrîsî établit une carte du monde et rassemble l'essentiel du savoir géographique de son temps.

\begin{abstract}
A la fin du XVe et au début du XVIe siècle, les grands navigateurs espagnols et portugais élargissent considérablement les connaissances géographiques. L'Amérique apparaît pour la première fois sur la carte $d u$ monde.
\end{abstract}

\section{L'Amérique}

A la fin du XVe et au début du XVIe siècle, les grands navigateurs espagnols et portugais élargissent considérablement les connaissances géographiques. L'Amérique apparaît pour la première fois sur la carte du monde. 
Les progrès de l'astronomie et des mathématiques ont une grande influence sur la cartographie. De nouveaux instruments permettent de mesurer les angles, de calculer latitude et longitude, d'apprécier les altitudes avec précision.

\section{Les Progrès de La Cartographie}

Les progrès de l'astronomie et des mathématiques ont une grande influence sur la cartographie. De nouveaux instruments permettent de mesurer les angles, de calculer latitude et longitude, d'apprécier les altitudes avec précision.
De nos jours, la cartographie connaît une véritable révolution. Le développement des capteurs numériques et la multiplication des instruments en orbite offrent la possibilité de décrire les zones terrestres les plus inaccessibles comme l'Antarctique.

\section{Cartographie de Nos Jours}

De nos jours, la cartographie connaît une véritable révolution. Le développement des capteurs numériques et la multiplication des instruments en orbite offrent la possibilité de décrire les zones terrestres les plus inaccessibles comme l'Antarctique.

Tanto os títulos quanto a divisão em slides é um trabalho das alunas, seguindo, em certos pontos, o texto original da Internet. Ao terminar a exploração do site do BNF, elas consideraram que o texto carecia de uma introdução e lançaram nova pesquisa com os termos «Definition de la Cartographie », encontrando o texto da Wikipédia que compõe os dois primeiros slides :

\begin{tabular}{ll|l|}
\hline La cartographie désigne la réalisation et & Definition de la Cartographie: \\
l'étude des cartes. Elle mobilise un ensemble & \\
de techniques servant à la production des & La cartographie désigne la réalisation et \\
cartes. La cartographie constitue un des & l'étude des cartes, un des moyens privilégiés \\
moyens privilégiés pour l'analyse et la & pour l'analyse et la communication en \\
communication en géographie. Elle sert à & géographie. \\
mieux comprendre l'espace, les territoires et & \\
les paysages. &
\end{tabular}

À l'époque moderne, les cartes se veulent une reproduction fidèle d'un paysage, d'une portion de l'espace terrestre : tous les éléments constitutifs d'un paysage sont représentés selon des conventions, avec des symboles. Chaque élément est représenté à l'échelle de la réalité ; les éléments trop petits en surface plane sont remplacés par des symboles d'une taille proportionnelle à leur importance relative (noms des villes de plus en plus grands selon leur population ou leur fonction administrative).
Les cartes se veulent une reproduction fidèle d'une portion de l'espace terrestre: chaque élément est représenté à l'échelle de la réalité . 
Esse foi um exemplo de leitura intensiva, bastante detalhada, que rendeu um trabalho excelente $^{180}$

A seguir vejamos um outro exemplo de pesquisa persistente não deu um resultado adequado:

"Professora: Como vocês escolheram o texto para ler?

Gabriela: Depois de pesquisar no Google e não achar nada, resolvemos partir para os links que a professora mandou. Mas acabei usando para começar um site que não estava nos links.

Inês: Eu fui direto aos links e achei um lá que tinha tudo. $O$ 'Des bateaux'.'

De fato, as duas alunas da dupla, embora amigas, são bastante independentes. Ambas lêem com segurança:

"Professora: Como está para entender a leitura?

(...) Gabriela: Dá para entender.

Professora: Então está fácil?

Inês: A gente sabe do que o texto está falando, então o que a gente não sabe a gente imagina. Dá para entender.

Professora: Então você entende pelo contexto?

Inês: $E^{\text {. }}$

Gabriela: É assim, como a gente já sabe o que o tema está tratando, a gente não chuta fora. A gente sabe dos limites que o tema traz.

Professora: Aí você chuta com base, é isso?

\footnotetext{
${ }^{180}$ A apresentação do trabalho em Power Point encontra-se no Anexo digital.
} 
Gabriela: Hum, hum.

Inês: Mas aquele texto é fácil!(...) Era muito fácil.”

Gabriela pesquisava o tema Les Marins e tinha a idéia de apresentar a hierarquia dos marinheiros dentro de um navio. Pedindo à professora a versão francesa das palavras isoladas, ela chegou a formular a frase «les grades occupés par les marins dans un navire ». Essa pesquisa resultou em um único site, que expunha de maneira bastante viva a hierarquia e as funções dos marinheiros em um navio :

\begin{tabular}{|l|l|}
\hline & Les grades occupés par les marins dans un \\
navire. & Capitain - Le capitaine est le grade de plus \\
grand autorité dans le navire. Il y a le pouvoir \\
sur tous les marins et sur le navire. Toute \\
décision par lui pris doit être exécutée. \\
Lieutenant - Le Lieutenant, ou Second, est le \\
principal relai du Capitaine. D'un point de vue \\
opérationnel il veille au bon déroulement des \\
opérations et prend le commandement du \\
navire si le Capitaine n'est plus apte à le faire.
\end{tabular}

\begin{tabular}{|l|l|}
\hline & Les grades occupés par les marins dans un \\
navire. & Cartographe -Responsable de la bonne tenue \\
des cartes, il s'assure de la bonne position du \\
navire et calcule les trajectoires au mieux pour \\
limiter le temps de voyage. \\
Courantographe -Ce dernier profite de sa \\
science des courants pour permettre au navire \\
de profiter de ces derniers et se déplacer plus \\
rapidement lors des affrontements. \\
Caliastre -Ce dernier profite de sa science des \\
étoiles pour permettre une navigation exacte de \\
nuit.
\end{tabular}

\begin{tabular}{|l|l|}
\hline & Les premiers maîtres \\
Premier Maître Artilleur - Le Premier Maitre \\
Artilleur encadre les marins oeuvrant aux \\
canons du navire. De par sa position, il est l'un \\
des dirigeants du bord et veille à l'amélioration \\
du matériel.
\end{tabular}




\begin{tabular}{|l|l|}
\hline & $\begin{array}{l}\text { Premier Maître Prétorien- Le Premier Maitre } \\
\text { Prétorien encadre les marins de la section } \\
\text { d'assaut. De par sa position, il est l'un des } \\
\text { dirigeants du bord et préside à l'entrainement } \\
\text { de tous au corps à corps. }\end{array}$ \\
\hline
\end{tabular}

\begin{tabular}{|l|l|}
\hline & Les premiers mâtres \\
Premier Maître Ballistique- Le Premier Maitre \\
Ballistique encadre les marins équipés de \\
Mousquets. De par sa position, il est l'un des \\
dirigeants du bord et entraîne le corps des \\
soldats équipés de Mousquet. \\
Premier Maître d'Atelier- Le Premier Maitre \\
d'Atelier encadre les marins oeuvrant au sein \\
de l'Atelier. De par sa position, il est l'un des \\
dirigeants du bord, travaille sur toute les \\
demandes de travaux déposées par les autres \\
Premier Maïtre - souvent dans l'urgence - et est \\
sûrement l'homme le plus surmené du navire. \\
\hline
\end{tabular}

Por estranhar a aparência do site, com o fundo todo em preto, cheio de figuras um tanto sinistras, ela evitou comentá-lo com a professora, para que a origem de seu texto não fosse criticada. Mais tarde, na pesquisa efetuada para o estabelecimento dos textos-base utilizados para as apresentações, sua fonte foi descoberta: tratava-se de um RPG (roleplaying game), no qual os marinheiros descritos eram personagens que deveriam ser encarnados por jogadores diversos ! ${ }^{181}$

O acompanhamento da pesquisa por parte da professora deve ser constante, embora ao ajudar ora uma dupla ora outra, reste de fato um espaço para a autonomia. Demaizière $(2003)^{182}$, na prática, recomenda que se espere, para intervir no trabalho, o chamado do aluno. Desse modo, é diferente o grau de ajuda que foi dado a cada dupla.

\footnotetext{
${ }^{181}$ Esse tipo de texto não permanece por tempo indefinido na Internet, pois ao ser terminado o jogo, ele normalmente é retirado do ar por seu organizador. Por este motivo, o endereço que obtivemos na pesquisa posterior à apresentação não é mais válido.

${ }^{182}$ Demaizière chama "pedagogia por cima do ombro" a essa orientação "intermitente" do trabalho dos alunos em Internet, em conferência com o título muito bem escolhido Autonomia: objetivo ou prérequisito?, na qual defende um equilíbrio entre uma intervenção excessiva - que faz no lugar do aluno - e
} 
"Professora: Como vocês leram?

Carol: No Babel Fish ${ }^{183}$ ou com a professora. (...)

Professora: Então vocês entendiam?

Karysa: Mais ou menos. O que a gente não entendia perguntava para a professora.

Carol: Eu entendi bastante, mas não tudo".

Mas até os alunos mais dependentes têm noção de que o objetivo a ser visado é uma maior autonomia:

"Professora: Como vocês estão fazendo para entender?

Stella: É assim: "Professora, o que é isso?"

Jéssica: Ou a gente pega um tradutor ou a gente pergunta para a professora.(...)

Stella: Aí a professora disse que estava errado e ela corrigiu para a gente. Ah, isso aí é para o seu mestrado?

Professora: Sim.

Stella: Aí Jéssica, vamos falar que estava ótimo senão a professora nunca vai ser mestra. "Olha, tava ótimo!" (risos)

Beaufils e Blondel (2001 : 31) relatam certa tendência, na pesquisa de alunos em Internet, a considerar que existe uma página ideal, a ser encontrada por meio da pesquisa, na qual está todo o trabalho pronto ${ }^{184}$. Esse foi praticamente o caso no trabalho de Mariana e Angel, a respeito da Cartografia. Entretanto, como no nosso caso o texto final requerido é muito simples, em relação à maior parte dos sites encontrados,

uma não-intervenção que leva o aluno a perder tempo e a se desencorajar, para guiar o trabalho em direção a uma verdadeira autonomia.

${ }^{183}$ Tradutor automático online.

${ }^{184}$ Essa crença é apontada por Beaufils e Blondel (2001 : 31), que alertam entretanto para o fato de que "se se trata de uma atividade escolar, os alunos têm direito de considerar - graças ao 'contrato didático' habitual - que a resposta pode ser encontrada com os métodos propostos pelo professor". 
a maior dificuldade não é a falta de dados, mas o excesso deles, ou sua excessiva complexidade. Esse foi o problema de Stella e Jéssica no trecho abaixo:

"Professora: E o outro site? Eu não pedi dois sites?

Stella: O outro não tinha nada.

Jéssica: A gente não conseguiu entender, então pegou na Wikipédia mesmo."

Entretanto, encontram-se já no texto de Internet funcionalidades que compensam as dificuldades apontadas para a leitura do hipertexto. A Wikipédia, por exemplo, é um dos endereços preferidos para a pesquisa, pois além da riqueza de temas (como diz Caroline, “A gente pesquisou primeiro na Wikipédia, porque sempre tem coisas”), possui uma estrutura fixa de redação dos verbetes que é muito vantajosa para a leitura-pesquisa em LE. Leiase, por exemplo, a narração de uma pesquisa por Stella e Jéssica:

"Professora: (...) Como vocês dividiram os slides?

Stella: A gente pegou entre as categorias de finalidades [finalidades da marinha].

Professora: Como descobriram as finalidades?

Stella: Já estava no sumário, a gente foi só clicando.

Professora: E dava para entender?

Stella e Jéssica: Dava.

Jéssica: Até eu consegui entender!

Stella: A gente não descobriu o que era "bateau de loisir", mas a gente continuou sem saber o que era. A gente pôs lá, achou uma foto.

Professora: Sem saber, como é que vocês acharam a foto?

Jéssica: Bom, a gente viu a foto e descobriu que era alguma coisa de passeio.

Professora: Então, e para resumir?

Stella: A gente não lia o texto inteiro, a gente só lia as primeiras linhas, selecionava e depois a professora tirava [mais] um pouco." 
O primeiro parágrafo do verbete da Wikipédia é um resumo do texto. Este é organizado com base em um sumário, bastante estrito, do qual também se podem acessar os trechos correspondentes do verbete - embora este se desenrole em uma única página Internet. As ilustrações são relativamente pequenas, não sobrecarregando o texto, porque há uma versão maior em outra página, que se acessa por hiperlink. Cada item contém um pequeno resumo de seu conteúdo, nas primeiras linhas do texto. Alguns itens do texto enviam para outros verbetes em que o subtema é desenvolvido com mais detalhe. Aqui está um exemplo, no trabalho de Stella e Jéssica. O texto-base, transcrito na coluna da esquerda, encontra-se no endereço: http://fr.wikipedia.org/wiki/Bateau

- $\underline{6}$ Utilisations et classification

- $\underline{6.1 \text { Navires de commerce }}$

Las finalités de la marine

- $\quad$ 6.2 Bâtiments militaires

- $\underline{6.3} \underline{\text { Bateaux de pêche }}$

- 6.4 Bateaux de loisir

- 6.5 Bateaux de compétition

○ $\underline{6.6} \underline{\text { Bateaux fluviaux }}$

Les navires de commerce comprennent trois grandes catégories: les cargos, les navires à passagers, et les navires de service et spécialisés.

Les navires à passagers transportent des personnes (...)

Les navires cargo servent au transport de marchandises sèches ou liquides. (...)
Jéssica Perassi e Stella Gubitoso
Leur coque est en acier, voire en aluminium pour les plus rapides; seuls les petits bateaux de service sont en plastique. (...)

Ils sont propulsés typiquement par une hélice unique entraînée par un moteur Diesel; les bateaux à grande vitesse emploient des hydrojets et parfois une turbine à gaz.
Leur coque est en acier, ou en aluminium ; les petits bateaux de service sont en plastique.

Ils sont propulsés par une hélice unique entraînée par un moteur Diesel ; les bateaux à grande vitesse emploient des hydrojets et parfois une turbine à gaz. 


\section{Bâtiments militaires}

Les navires de guerre modernes sont divisés en différents types correspondant à leur armement, leur taille et leur mission. (...)
Bâtiments militaires

Les navires de guerre modernes sont divisés en différents types correspondant à leur armement, leur taille et leur mission.

\section{Bâtiments militaires}

Ces bateaux ont généralement des formes fines et des machineries dédiées à la vitesse et à la manouvrabilité. Ils incluent de nombreux systèmes électroniques, de communication et d'armement logés dans un espace confiné.

\section{Bâtiments militaires}

Ces bateaux ont généralement des formes fines et des machineries dédiées à la vitesse et à la manœuvrabilité.

\section{Bateaux de pêche}

Les bateaux de pêche peuvent être assimilés à des navires commerciaux, mais leur dimensions réduites et leur utilisation souvent « artisanale » les font souvent classer à part. Ils sont classés selon plusieurs critères : selon le type de poisson qu'ils pêchent (ainsi les thoniers, sardiniers, crevettiers...) ; selon la méthode de pêche utilisée (d'où les chalutiers, les fileyeurs, les bolincheurs...) ; ou selon leur origine géographique ou caractéristiques techniques tels que le gréement : sinagos, lanches, bisquines...

Ces bateaux sont souvent petits (une centaine de mètres pour les grands thoniers ou baleiniers, mais souvent guère plus de 20 à 30 $m$ ), ventrus et dotés de cales suffisamment grandes pour une bonne autonomie. Le poisson pêché peut être simplement stocké dans de la glace, ou traité directement à bord pour pouvoir être vendu plus rapidement une fois au port ; (...)
Bateaux de pêche

Les bateaux de pêche sont classés selon le type de poisson qu'ils pêchent (ainsi les thoniers, sardiniers, crevettiers...); selon la méthode de pêche utilisée ; ou selon leur origine géographique ou caractéristiques techniques ...

\section{Bateaux de pêche}

Ces bateaux sont souvent petits (une centaine de mètres pour les grands thoniers ou baleiniers, mais souvent guère plus de 20 à 30 $\mathrm{m})$, ventrus et dotés de cales suffisamment grandes pour une bonne autonomie.

\begin{tabular}{|l|l|}
\hline Bateaux de loisir & Bateaux de loisir \\
Les bateaux de plaisance regroupent & Les bateaux de plaisance regroupent \\
notamment les voiliers et les yachts qui & notamment les voiliers et les yachts qui \\
servent aux loisirs ; ceux-ci incluent le & servent aux loisirs. \\
nautisme à voile ou motorisé, la croisière & \\
côtière et hauturière, la promenade) la journée, \\
voire le simple fait de rester au port pour \\
certains grands yachts de luxe!
\end{tabular}

Bateaux de compétition

Les bateaux de compétition sont ceux destinés aux régates et autres compétitions sportives telles que les records de vitesse ou de distance. Parmi les voiliers (...)

\section{Bateaux de compétition}

Les bateaux de compétition sont ceux destinés aux régates et autres compétitions sportives telles que les records de vitesse ou de distance. 
Bateaux fluviaux

La navigation fluviale a de tous temps représenté un moyen privilégié pour le déplacement des hommes et des marchandises, avant même le développement de la navigation maritime. Le symbole de la Louisiane est souvent lié à ces célèbres bateaux à fond plat mus par des roues à aube
Bateaux fluviaux

La navigation fluviale a de tous temps représenté un moyen privilégié pour le déplacement des hommes et des marchandises, avant même le développement de la navigation maritime.

O texto leva, portanto, naturalmente, para uma leitura seletiva, após uma eficiente varredura com base no resumo e após ter-se chegado ao texto por meio da busca de uma palavra-chave. O projeto permitiu uma grande variedade de leituras propiciada pelo texto de Internet, entre elas:

1. a leitura global para a escolha dos sites para a consulta, conforme praticada por Akira,

2. a leitura detalhada, como no item Histoire de la Cartographie,

3. a leitura seletiva, guiada pelos links, do item Finalités de la Marine,

4. a experiência de leitura com o tradutor automático, de Caroline, Jéssica e Danillo,

5. a compreensão de termos pelo contexto de Inês e Gabriela.

Nem todo o material produzido pelo estudo foi analisado, assim, a leitura em voz alta, transcrita no Anexo 3, não foi avaliada, por falta de tempo; do mesmo modo, o exame dos textos produzidos para as apresentações poderia ter sido objeto de um estudo mais detalhado. Entretanto, devido à grande quantidade de variáveis envolvidas nos Projetos, acreditamos que os aspectos já ponderados são suficientes para chegar a algumas conclusões. 


\section{b. Avaliação do projeto}

Pela análise dos textos, dos depoimentos sobre a pesquisa coletados por meio das entrevistas e pela opinião expressa nas auto-avaliações, concluímos que houve um resultado compatível com o esperado para o nível dos alunos e, em alguns casos, melhor que o esperado. Em termos de objetivos lingüísticos, verificou-se a leitura em todas as modalidades requeridas pela pesquisa, além da leitura de textos longos e a seleção de trechos pertinentes. Houve ganhos também na habilidade de pesquisa em Internet, conforme observamos e conforme opinião dos alunos, expressa na auto-avaliação. O projeto atingiu igualmente seus objetivos "afetivos": produziu um aumento na confiança com que os alunos abordam a leitura, encaminhando-os para a autonomia. Esses ganhos foram duráveis, como vimos no "projeto-relâmpago" que se seguiu à apresentação, e em outros trabalhos posteriores. Esse tipo de projetos pode ser considerado também um procedimento estabilizado, para a disciplina, em nosso colégio, o que permite o recurso a ele em várias ocasiões.

Em relação aos projetos anteriores, obtivemos no projeto Histoire de la Technologie Maritime uma maior compreensão dos pressupostos teóricos, uma avaliação mais constante e inserida em todas as fases do projeto, uma maior inserção nas rotinas e procedimentos do colégio, o estreitamento dos "laços" interdisciplinares e uma sedimentação maior das aquisições, graças ao procedimento das "retomadas". 


\section{Conclusão do Capítulo V}

Adotamos em nosso trabalho uma metodologia de pesquisa qualitativa, aderindo à reflexão de Mangenot a respeito daquela empregada pelos estudos sobre o uso das tecnologias na pedagogia de FLE. Essa metodologia nos permite avaliar os objetivos e resultados de um único objeto de experiência, que permita, por suas características, ser oferecido como exemplo. Os parâmetros empregados para a construção de nossos projetos foram a leitura como competência a ser desenvolvida através de procedimentos específicos; a Internet, como fonte inesgotável de recursos para a leitura em francês e como ambiente motivante para o trabalho com adolescentes e uma estrutura interdisciplinar, com vistas à autonomia de leitura. Os projetos interdisciplinares inserem-se no projeto pedagógico do Colégio como elemento produtor de motivação por seu caráter ativo, por apresentar a língua estrangeira como um instrumento de aprendizagem, pela integração entre as disciplinas e por colaborar com a inserção da instituição na comunidade. Os projetos anteriores obedeceram a formatos variados, que nos permitiram aperfeiçoar os procedimentos experimentados. O projeto Histoire de la Technologie Maritime, desenvolvido para ser apresentado na feira de História e Geografia do Colégio, a II FeClio, em 19.04.08, pela turma de 1o. ano do Ensino Médio, permitiu ganhos significativos e verificáveis no processo de leitura em francês dos alunos envolvidos, em termos de autoconfiança e diversificação de procedimentos de leitura, além de progresso na habilidade de pesquisa em Internet. 


\section{Conclusão Geral}

Ao iniciar o presente estudo, propusemo-nos a refletir sobre um procedimento metodológico de ensino de Francês para alunos do Ensino Médio que utilizasse o ambiente Internet. A leitura, como competência a ser desenvolvida, surgiu naturalmente, por ser a atividade por excelência do usuário da Internet. Nossos estudos a respeito da natureza da leitura em língua estrangeira e da sua compatibilidade com formas de leitura em Internet mostraram grandes vantagens no uso desse instrumento, desde que inserido em um processo pedagógico reflexivo. Os projetos de aprendizagem, segundo autores como Puren, Tardif, Mangenot e outros, representam uma escolha coerente e adequada para a inserção da Internet no ensino de Francês como língua estrangeira. Do mesmo modo, por seu aspecto ativo, interdisciplinar e voltado para a comunidade, os projetos inserem-se muito bem na política pedagógica do colégio onde foram realizados. Finalmente, a associação de todos esses fatores, tanto aqueles que envolvem Internet como a motivação, a experiência de modos de leitura, o desenvolvimento da habilidade de pesquisa, o trabalho em autonomia; quanto aqueles relativos aos projetos como a oportunidade de apresentação dos trabalhos durante um evento visando a integração da escola na comunidade, foi particularmente benéfica aos alunos, o que recomenda seu emprego em outras circunstâncias. 


\section{Referências bibliográficas}

ALAVA, S. Vers une mutation des pratiques d'enseignement scolaires...des mirages aux usages Pôle Grand Est, École d'été 1998 IUFM de Franche-Comté, Disponível em http://iufm.univ-fcomte.fr/ecolete/conferen/alavaab.htm Acessado em 13.10.08.

ARBER, W. Expériences d'enseignement transdisciplinaire à l'Université de Bâle traduction de Henri Klinger. Bulletin Interactif du Centre International de Recherches et Études transdisciplinaires n 7-8 - Avril 1996. Disponível em http://nicol.club.fr/ciret/bulletin/b7et8c2.htm . Acessado em 18.10.08.

ARÉVALO BENITO, M.J. La lecture et le document authentique en classe de FLE Estudios franceses y francófonos : El texto como encrucijada, Coord. I. Iñarrea Las Heras, M. J. Salinero Cascante, vol. 2, Universidad de La Rioja, 2003. pp. 607-616. Consultado em 08.10.08. Disponível em dialnet.unirioja.es/servlet/fichero_articulo?codigo=1011623\&orden=74723

BAKHTIN, M. M. Estética da criação verbal trad. M. E. G. G. Pereira, Coleção Ensino Superior, São Paulo : Ed. Martins Fontes, 1992.

BARBIER, M. TIC et enseignement des langues Qui commande?

Université d'Uppsala, Département de la Formation continue, http://www.linguatic.fba.uu.se/articles/fr/TIC_et_enseignement.htm 
BARBOSA, A.C.L.S. Leitura e Escrita na Web in Revista Linguagem em (Dis)curso, volume 5, número 1, 2005. Disponível em http://www3.unisul.br/paginas/ensino/pos/linguagem/0501/08.htm Consultado em 05.11.08.

BARBOT, M.-J. Les auto-apprentissages Collection Didactique des Langues Étrangères, Paris : Clé International, 2002.

BARBOT, M.-J., PUGIBET, V. Introduction in Le français dans le monde : Recherches et applications : Apprentissages des langues et technologies : usages en émergence, janvier 2002. Paris : Cle International, FIPF, pp.4-6.

Médiatisation dans l'enseignement supérieur: vers un nouveau paradigme éducatif? Revue ALSIC, Vol. 6, Numéro 1, pp 175 - 189, juin 2003. alsic.u-strasbg.fr/Num10/barbot/alsic_n10-rec7.htm

BEACCO, J.-C. Les orientations du Conseil de l'Europe en matière linguistique in L'enseignement des langues vivantes, perspectives. Actes du séminaire Direction générale de l'Enseignement scolaire, publié le 25 octobre 2001 Disponível em http://eduscol.education.fr/D0033/langviv-acte4.htm Acessado em 24.05.08.

BEAUFILS, A. ; BLONDEL, F.-M. Les pratiques de recherche d'information sur Internet Les dossiers de ingénierie éducative, Les TPE, n.34, février 2001, pp. 31-35, Paris : CNDP 
BELISLE, C Enjeux et limites du multimédia en formation et en éducation.

Les cahiers de l'Asdifle Multimédia et français langue étrangère, Actes des 19e. et 20e. rencontres, Paris, janvier 1997, Poitiers, septembre 1997.

BERTHAUX, F et allii Les TPE vers une nouvelle pédagogie : débat à l'occasion d'une publication Les dossiers de ingénierie éducative, Les TPE, n.34, février 2001, pp.8-16. Paris : CNDP. Disponível em 23.05.08 em http://www.weblettres.net/ar/articles/7_40_103_34debat.pdf

BIZARRO, R. Aprender, ensinar, avaliar em F.L.E. (3º ciclo do Ensino Básico): alguns percursos para uma autonomia Porto: Universidade do Porto. Disponível em http://ler.letras.up.pt/uploads/ficheiros/artigo8291.pdf.

BLIN, F. ; DONOHOE, R. Projet TECHNE : vers un apprentissage collaboratif dans une classe virtuelle bilingue Alsic, Vol. 3, numéro 1, pp. 19 - 47, juin 2000. Disponível em http://alsic.u-strasbg.fr/Num5/blin/alsic_n05-rec8.htm Acessado em 09.08.07.

BOGAARDS, P. Aptitude et affectivité dans l'apprentissage des langues étrangères Collection Langues et Apprentissages des Langues, Paris : Didier Hatier, 1991.

BOUVET, E., BRÉELLE, D. Pistage informatisé des stratégies de lecture : une étude de cas en contexte pédagogique, Flinders University, Australie, Revue ALSIC, Vol. 7, numéro en cours, article mis en ligne en juin 2004 , alsic.org ou alsic.u-strasbg.fr 
BOYER, H. ; BUTZBACH, M. ; PENDANX, M. Nouvelle introduction à la didactique du français langue étrangère, in Le Français sans frontières : outils pédagogique, Paris, Clé International, 2001.

BRODIN, E. Innovation, instrumentation technologique de l'apprentissage des langues : des schèmes d'action aux modèles de pratiques émergentes ALSIC Vol. 5, Numéro 2, décembre 2002, pp 149-181. Disponível em http://alsic.u$\underline{\text { strasbg.fr/Num09/brodin/alsic_n09-rec3.htm }}$ Consultado em 01.11.08.

BRODIN, E. Analyse de Didactique des langues et TIC : vers une recherche-action responsable in $\boldsymbol{A L S I C}$ décembre 2007, pp. 95-103. Disponível em http://alsic.ustrasbg.fr/Menus/frameder.htm Consultado em 29.09.08.

CADRE EUROPÉEN COMMUN DE RÉFERENCE POUR LES LANGUES : APPRENDRE, ENSEIGNER, ÉVALUER Strasbourg, Conselho da Europa, 2000

CAPOVILLA, A., CAPOVILLA, F. Problemas de leitura e escrita: como identificar, prevenir e remediar numa abordagem fônica, São Paulo, Memnon. 2000.

CARTON, F. L'apprentissage differencié des quatre aptitudes Didactique du Français Langue Etrangère. Marie-José Gremmo (dir). VERBUM P.U.N.1995. Disponível em http://www.epc.univ-nancy2.fr/EPCP_F/pdf/Apprentissage\%20differ.pdf Acessado em 07.09.07. 
CASTELLOTTI, V. La langue maternelle en classe de langue étrangére Collection

Didactique des Langues Étrangères. Paris : Clá International, 2001.

CASTELLOTTI, V.; MOORE, D. Cultures éducatives et construction de compétences plurilingues. Marges linguistiques, Juillet 2004. Disponível em 14.10.07 em www.revue-texto.net/marges/marges/Documents\%20Site\%206/

CHACHATY, E. L’hyperlivre, in Le Français Dans Le Monde, N`309 Mars-avril 2000. Disponível em http://www.fdlm.org/fle/article/309/chachati.php Consultado em 12.10.06.

CHARLIER, P Jeux hypermédias et expérience d'apprentissage Communication au colloque "Savoirs formels - savoirs informels" Louvain-la-Neuve, 14-15 décembre 2000 www.comu.ucl.ac.be/RECO/GREMS/philweb/informel.pdf Consultado em 27.10.08.

CHARLIER , P. L'expérience d'apprentissage par les hypermédias : le cas de lycéens de 16 à 18 ans Paru dans les Actes du Forum international "Les jeunes et les médias demain", UNESCO, Paris, 21-25 avril 1997. Disponível em www.comu.ucl.ac.be/reco/grems/philweb/unesco.htm Consultado em 27.10.08.

CHARNET, C. L'hypertexte : une perception associative du monde francophone et un nouvel outil pour apprendre, in Colloque international de l'université de Toulouse le Mirail: Langue étrangère et/ou seconde : de l'expérimentation à la réalité dans l'espace francophone, 25 et 26 mars 1999. Disponível em http://www.educnet.education.fr/chrgt/FLEtoulouse4.rtf . Acessado em 20.08.04. 
CHARTIER, R A aventura do livro: do leitor ao navegador, São Paulo, Ed.Unesp, 1999.

CHUONG, V.V. Procédés anaphoriques et lecture en FLE Le Français dans le Monde Mai-juin 2003 - `o327 Disponível em http://www.fdlm.org/fle/article/327/vanchuong.php Acessado em 07.09.07.

CLAEYSSEN, Y : Hypertextes et hypermédia, 1994. DEA Université de Lille 3. Disponível em http://home.nordnet.fr/ yclaeyssen/ Acessado em 12.11.08.

COBB, T. ; GREAVES, C. ; HORST, M. Peut-on augmenter le rythme d'acquisition lexicale par la lecture ? Une expérience de lecture en français appuyée sur une série de ressources en ligne in RAYMOND, P.; CORNAIRE, C. Regards sur la didactique des langues secondes Montréal: Éditions logique 2001 pp. 133-153. Disponível em http://www.er.uqam.ca/nobel/r21270/cv/BouleF.htm Acessado em 08.10.07.

COIRIER, P., GAONAC'H, D., PASSERAULT, J.-M. Psycholinguistique textuelle : approche cognitive de la compréhension et de la production des textes, Paris, Armand Colin. 1996.

COMITÊ PARA DEMOCRATIZAÇÃO DA INFORMÁTICA Boletim Informativo. Maio/2003 - Ano 2 - nº 12. Disponível em www.cdi.org.br. Acessado em 19.08.04.

CORNAIRE, C. Le point sur la lecture Paris : Clé International, 1999. 
COSTE, D. La compétence plurilingue et ses implications possibles in L'enseignement des langues vivantes, perspectives. Actes du séminaire. Paris : Direction générale de l'Enseignement scolaire, publié le 25 octobre 2001. Disponível em http://eduscol.education.fr/D0033/langviv-acte3.htm .Acessado em 24.05.08.

Multimédia et corriculum multidimensionnel in Ateliers: Outils multimédias et stratégies d'apprentissage du français langue étrangère, tome I, Cahiers de la Maison de la Recherche, Université Charles de Gaulle, Lille III, 1996.

COURTILLON, J. Élaborer un cours de FLE Paris : Hachette, 2003.

Penser le déroulement des cours : organiser les activités pour apprendre Le français dans le monde Janvier-février 2002 - N³31. Disponível em http://www.fdlm.org/fle/article/331/cours331.php Acessado em 07.10.07. CUQ, J.-P. org. Dictionnaire de didactique du français langue étrangère et seconde Paris.,ASDIFLE, Clé international, 2003.

CUSTERS, G. ; PAQUIER, E. ; RODIER, C. 150 activités avec l'Internet : niveau intermediaire, Le Nouvel Entraînez-vous. Paris : Clé International, 2004.

DEBEUGNY, M. La dyslexie : être dyslexique au jour le jour EduFLE.net, 2005. Disponível em http://www.edufle.net/La-dyslexie Consultado em 24.10.08. 
DEMAIZIÈRE, F. Autonomie : objectif ou prérequis ? Intervention à l'IUFM de Versailles, 2003. Disponível em http://didatic.net/article.php3?id_article=15 Acessado em 16.10.08.

Autoformation : des approches classiques aux discours d'aujourd'hui Université Lyon 2 - conferência proferida em 2003. Disponível em http://didatic.net/article.php3?id_article=25\#hautpage Acessado em 30.07.07.

Environnements multimédia : à la recherche des ressources et des méthodologies adéquates Journée Le multimédia dans l'enseignement des langues étrangères : vers un renouveau pédagogique ? Université de Neuchâtel - ILCF 5 décembre 2006. Disponível em http://didatic.net/article.php3?id_article=98 Acessado em 30.07.07. ; NARCY-COMBES, J.-P. Méthodologie de la recherche didactique : nativisation, tâches et TIC. Apprentissage des langues et systèmes d'information et de communication (ALSIC), vol. 8, n 1. pp. 45-64, 2005. Disponível em http://alsic.u-strasbg.fr/v08/demaiziere/alsic_v08_14-rec8.htm Acessado em 13.08.07.

DE PARTZ, M.P. Os modelos da leitura competente , in VAN HOUT , A., ESTIENNE, F. - Dislexias: descrição, avaliação, explicação, tratamento. $2^{\text {a }}$. ed. Porto Alegre, Artmed, 2001.

DE VECCHI, G. Aider les élèves à apprendre Collection Nouvelles Approches, Paris : Hachette Éducation, 2.ed. 2001. 
DEVELOTTE C. Écriture multimédia et nouvelle construction du savoir in Les cahiers de l’Asdifle n9, Actes du Colloque de l'Asdifle, Paris 1997.

DEVELOTTE, C. Lecture et cyberlecture, Le Français dans le monde. Recherches et applications, 1997, pp. 94-104. Version de l'auteur disponible sur Internet : [ http://halshs.archives-ouvertes.fr/halshs-00151858 ] Consultado em 27.10.08.

DEVELOTTE, C. ; LANCIEN, T. Propositions pour l'analyse des discours multimédia : l'exemple de deux articles encyclopédiques in LANCIEN, T.; (Ed.) Multimédia : les mutations du texte 2000, pp. 119-138. Version de l'auteur disponible sur Internet : [ http://halshs.archives-ouvertes.fr/halshs-00151848 ] Consultado em 27.10.08.

DUBREUIL, R. L'embarquement pour « cyber » ? L'Homme nouveau, HN 2144 - 19 novembre 2000. http://maranatha.mmic.net/Hommenouveau.html

DUCHIRON, E. Les technologies de l'information et de la communication dans l'enseignement / apprentissage des langues : Atouts, limites \& exploitations potentielles du choix fourni Mémoire de DEA, sous la direction de Mme Françoise DEMAIZIÈRE . Université de Paris III, Faculté de Didactique du Français Langue Étrangère, 2002-2003. Disponível em http://didatic.net/article.php3?id_article=30 Consultado em 01.11.08.

DUQUETTE, L. Analyse de données en apprentissage d'une L2 en situation d'autonomie dans un environnement multimédia In Revue ALSIC, Vol. 5, Numéro 1, pp 33 - 53 mars 2002, Disponível em alsic.org ou alsic.u-strasbg.fr 
DWYER, Tom et al . Desvendando mitos: os computadores e o desempenho no sistema escolar. Educação e Sociedade, Campinas, v. 28, n. 101, 2007 . Disponível em: http://www.scielo.br/scielo.php?script=sci_arttext\&pid=S0101$\underline{73302007000400003 \& \operatorname{lng}=\& n r m=\text { iso }}$ Acessado em 31.10.08.

ECO, U. Da Internet a Gutenberg, Conferência apresentada por Umberto Eco na The Italian Academy for Advanced Studies in America (12 de novembro de 1996) traduzida por João Bosco da Mota Alves da Universidade Federal de Santa Catarina, Disponível em http://www.inf.ufsc.br/ jbosco/InternetPort.html

O dilúvio da informação entrevista a Tânia Menai in Veja: vida digital, dezembro 2000. Disponível em http://veja.abril.com.br/especiais/digital4/entrevista.html Consultado em 10.11.08.

FAYOL, M Un parti pris : promouvoir une lecture autonome en mettant l'accent sur la compréhension Les journées de l'ONL, janvier 2001 Disponível em http://onl.inrp.fr/ONL/publications/publi2001/lecture8-11/ Acessado em 13.09.07.

FAYOL, M.; MORAIS, J. La lecture et son apprentissage Les journées de l'ONL, janvier 2004 Disponível em http://onl.inrp.fr/ONL/publications/publi2004/evolution/ Acessado em 13.09.07.

FERREIRO, E. Reflexões sobre a alfabetização São Paulo : Cortez, Autores Associados. 1998. 
FERRY, F. Et maintenant, ouvrez les « fenêtres »! Les dossiers de ingénierie éducative, Les TPE, n.34, février 2001, pp.1-5. Paris : CNDP. Disponível em 23.05.08 em http://www.weblettres.net/ar/articles/7_40_104_34ff.pdf

FRANCOEUR BELLAVANCE, S Le travail en projet : Une stratégie pédagogique transdisciplinaire. Longueil (Québec) : INTÉGRA Centre de Pédagogie transdisciplinaire, 1996. Disponível em http://www.centre-integra.com/index.htm Consultado em 29.09.08.

GAONAC'H, D., FAYOL, M. (coord.) Aider les élèves à comprendre : Du texte au multimédia. Paris : Hachette, 2003.

GAONAC'H, D. La lecture en langue étrangère : un tour d'horizon d'une problématique de psychologie cognitive AILE (Aquisition et Intéraction en Langue Étrangère) $\mathrm{n}^{\circ}$ 13. 2000 Disponível em http://aile.revues.org/document970.html Acessado em 14.08.07.

GERMAIN, C. Évolution de l'enseignement des langues : 5000 ans d'histoire Paris : Clé International, 1993.

GIARDINA, M. ; OUBENAÏSSA, L. Projet d'apprentissage/enseignement en ligne In Revue Sciences et techniques de l'information et de la communication pour l'education et la formation, Université Le Mans. 2003. 
GIASSON, J. La lecture : de la théorie à la pratique Québec : Gaëtan Morin, 2.ed. 2003.

La compréhension en lecture Québec : Gaëtan Morin, Bruxelles : De

Boeck.1990.

GOARANT, B. Pour un usage raisonné du multimédia In Revue Le Français Dans Le Monde, n. 302, janvier-février 1999.

GODINET, H. Hypermédias et parcours labyrintiques: vers une rhétorique de l'hypertexte, in Revue Le français d'aujourd'hui, Ordinateur et textes:une nouvelle culture?, no. 129, Association Française d'Enseignants de Français, Paris, mars 2000.

GODINET, H \& CARRIÈRE, C. Hypertexte vous avez dit hypertexte ?, 1994.

Disponível em http://www.grenoble.iufm.fr/departe/francais/hypertxt Acessado em 23.05.08 (não encontrado em 17.11.08).

GOMES, L.F. A interação na leitura de hipertextos educacionais : um estudo sobre as possibilidades didáticas da utilização do hipertexto. Campinas: Unicamp, 2006. Disponível em http://www.abed.org.br/seminario2006/pdf/tc025.pdf Acessado em 23.05.08

GOODMAN, K.S. O processo de leitura : considerações a respeito das línguas e do desenvolvimento in FERREIRO, E.; PALACIO, M. (org.). Novas perspectivas sobre os processos de leitura e escrita. Porto Alegre: Artes Médicas, 1988. 
GOTTI, D. Pratique de la lecture: le cas des langues voisines Culture, 10, 1996. Milão. Disponível em http://www.club.it/culture/danielle.goti/corpo.tx.goti.html Acessado em 07.09.07.

GRÉGOIRE, R. ; LAFERRIÈRE, T. Apprendre ensemble par projet avec l’ordinateur en réseau RESCOL Réseau scolaire canadien, 1998, 2001. Disponível em http://www.tact.fse.ulaval.ca/fr/html/sites/guidep.html . Acessado em 14.10.07.

HEBERT, M Co-élaboration du sens dans les cercles littéraires entre pairs en première secondaire : étude des relations entre les modalités de lecture et de collaboration Thèse présentée à la Faculté des études supérieures, Université de Montréal. 2002.

HILTON, H. L’Accès au lexique mental dans une langue étrangère : le cas des francophones apprenant l'anglais. Corela , Volume 1, Numéro 2. 2003 Disponível em http://edel.univ-poitiers.fr/corela/document.php?id=80 Acessado em 07.10.07.

HOLEC, H. Qu'est-ce qu'apprendre à apprendre ? Mélanges CRAPEL, 1990. Nancy, Université Nancy 2. Disponível em 14.10.07 em http://revues.univ-

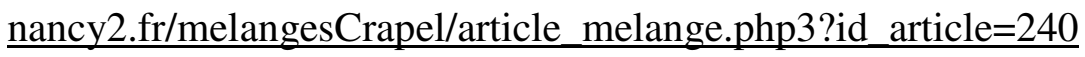

Internet World Stats : Usage et Population Statistics, 2008. Disponível em http://www.internetworldstats.com/stats.htm Consultado em 26.10.08. 
Internet World Users by Language in Internet World Stats : Usage et Population Statistics, 2008. Disponível em http://www.internetworldstats.com/stats7.htm Consultado em 26.10.08.

JACQUINOT-DELAUNAY, G. Les NTIC: Ecrans du savoir ou Ecrans au savoir? In Moeglin, P., Coste, D., Portine, H. (Ed.), Outils multimedia et strategies d'apprentissage du Français Langue Etrangère. Lille : Université de Lille 3. 1996. Disponível em http://www.univ-lille3.fr/Colloques/colloque_FLE/jacquino.pdf.

JAMET, E. Une présentation des principales méthodes d'évaluation des EIAH en psychologie cognitive Revue STICEF (Sciences et Technologies de l'Information et de la Communication pour l’éducation et la Formation), Le Mans : Volume 13, 2006. Disponível em http://sticef.univ-lemans.fr/num/vol2006/jamet09/sticef_2006_jamet_09p.pdf Acessado em 20.10.07.

KLEIMAN, A.B.; MORAES, S.E. Leitura e interdisciplinaridade: tecendo redes nos projetos da escola. Campinas: Mercado de Letras, 2003.

KUNDMAN, M. S. As línguas estrangeiras e o ensino de línguas na rede pública : perspectivas de mudança? Revista Linguagem Ensino Tela Textos Em Lingüística Aplicada, Pelotas, 2000.

Ensinando e Aprendendo o Francês em nível universitário: experiências na USP. Tese de doutoramento, FFLCH-USP, 1994. 
Lingua e Literatura Francesa Estudos Avançados., São Paulo, v.

8, n. 22, 1994. Disponível em

http://www.scielo.br/scielo.php?script=sci_arttext\&pid=S0103-

40141994000300060\&lng=en\&nrm=iso $>$. Acessado em 27.09.07.

LANCIEN, T. Le multimédia, Paris : Clé International. 1998 (Collection Didactique des Langues Étrangères)

LEGROS, D. ; MAÎTRE DE PEMBROKE, E. L'évaluation du rôle des Nouvelles Technologies sur l'apprentissage et l'enseignement dans le nouveau contexte mondial interculturel. Quelles perspectives ? Débat interculturel sur l'évaluation des systèmes éducatifs. Université Mentouri, Constantine, Algérie. (Actes, pp. 51-63), 2001.

LEGROS, D.; PUDELKO, B.; CRINON, J. (2001). Les nouveaux environnements technologiques et l'apprentissage collaboratif. In J. Crinon \& C. Gautellier (Eds.) Apprendre avec le multimédia et Internet pp.203-214. Paris : Retz. Disponível em http://www.enseignants.com/ressources/Dossier/environnements.pdf

LEHMANN, D. Lire en français langue étrangère (1968-1988) : bilan et perspectives in COSTE, D. org. Vingt ans dans l'évolution de la didactique des langues (1968-1988) Crédif, Paris : Didier.1994

LEINER, B.M., CERF, V. et allii História da Internet Tradução de Aisa Pereira, de "A Brief History of the Internet", escrita por Barry M. Leiner, Vinton G. Cerf, David D. 
Clark, Robert E. Kahn, Leonard Kleinrock, Daniel C. Lynch, Jon Postel, Larry G.

Roberts e Stephen Wolff, criadores da Internet. Disponível em

http://www.aisa.com.br/historia.html Consultado em 26.10.08.

LEMOS A. La cyber-socialité Sociétés, Bruxelles, De Boeck \& Larcier, 1996, no 51, pp. 29-38. Disponível em http://cat.inist.fr/?aModele=afficheN\&cpsidt=3167150 Consultado em 28.10.08.

LÉVY, P. La cyberculture. Paris : Odile Jacob, 1997.

LÉVY, P. Qu'est-ce que le virtuel? Paris, Éditions La Découverte, 1995.

LOMBART, B. La synecdoque et le lien hypertexte. Disponível em:

http://www.synec-doc.be/doc/tropes.htm Acessado em 12.10.06.

MACHADO, Arlindo. Máquina e imaginário: O desafio das poéticas tecnológicas. São Paulo, Editora da Universidade de São Paulo, 2001. 3. ed.

MALHEIROS POULET M.-E., DEGACHE C., MASPERI M., L'activité de compréhension écrite en langues voisines (domaine des langues romanes) : stratégies d'accès au sens de textes narratifs, in J.-C. Pochard (éd.), Actes du IXe colloque international Acquisition d'une langue étrangère: perspectives et recherches. Profils d'apprenants, Publications de l'Université de Saint-Etienne, 335-350. 1994. Disponível em www.galanet.eu/publication/fichiers/mp-dc-mm1994.pdf Acessado em 13.08.07. 
MANGENOT, F. Classification des apports d'Internet à l'apprentissage des langues in Revue ALSIC, Vol. 1, numéro 2, pp 133 - 146, décembre 1998. Disponível em http://alsic.u-strasbg.fr/Num2/mangenot/alsic_n02-pra1.htm Acessado em 09.08.07.

Seize ans de recherches en apprentissage des langues assisté par ordinateur. In Plurilinguisme et apprentissages, Mélanges Daniel Coste, p. 313-322. Lyon, ENS Editions, 2005. Disponível em w3.ugrenoble3.fr/espace_pedagogique/16acao.rtf Acessado em 03.08.07. Une formation « située » de futurs enseignants au multimédia in TARDIEU, C. \& PUGIBET, V. Langues et cultures. Les TIC, enseignement et apprentissage. Paris, CNDP, Dijon, CRDP Bourgogne, p. 123-133. 2005 Disponível em http://w3.u-grenoble3.fr/espace_pedagogique/iufm-paris-mangenot.doc Acessado em 03.07.07.

\section{MANGENOT, F., POTOLIA, A., COSTE, D. Ressources en ligne pour} l'enseignement / apprentissage du français et d'autres langues européennes : étude typologique et comparative. Etude préparée à la demande du ministère des Affaires étrangères (sous-direction du français), 2001. Disponível em http://hyperbul.org/numero6/zoom/Mangenot.pdf Acessado em 02.11.08.

MANGIANTE, J.-M. ; PARPETTE, C.Le français sur objectif spécifique : de l'analyse des besoins à l'élaboration d'un cours Paris : Hachette FLE, 2004. 
MARCOTTE, S. L'hypertexte Astrolabe, Université Ottawa, 1999. Disponível em http://www.uottawa.ca/academic/arts/astrolabe/articles/art0003.htm Acessado em 11.10.2006.

MARCUSCHI, L.A. A coerência no hipertexto, in I Seminário Sobre Hipertexto, Centro De Artes E Comunicação, Universidade Federal De Pernambuco, Recife, 16 e 17 de outubro de 2000. Disponível em http://bbs.metalink.com.br/ lcoscarelli/Marcuschicoerhtx.doc Acessado em 20.08.04.

MARCUSCHI, L.A Gêneros textuais emergentes e atividades lingüísticas no contexto da tecnologia digital Versão provisória Conferência apresentada no Grupo de Estudos Lingüísticos do Estado de São Paulo, Universidade de São Paulo, 2002.

MARQUILLO-LARRUY, M. L'interprétation de l'erreur Collection Didactique des Langues Étrangères. Paris : Clé International, 2003.

MOEGLIN, P. Multimédia et éducation : le demon de la convergence in Moeglin, P., Coste, D., Portine, H. (Ed.), Outils multimedia et strategies d'apprentissage du Français Langue Etrangère. Lille : Université de Lille 3. 1996.

MOIRAND, S. Situations d'écrit : compréhension, production en langue étrangère Paris, Clé International, 1979. 
MORIN, E. Sur l'interdisciplinarité Bulletin Interactif du Centre International de

Recherches et Études transdisciplinaires nº 2 - Juin 1994. Disponível em http://nicol.club.fr/ciret/bulletin/b2c2.htm . Consultado em 17.10.08.

NARCY, J.-P. Apprendre une langue étrangère : didactique des langues : le cas de l'anglais Paris : Les Éditions de l’Organisation, 1990.

OUDART, P. Pour un internet francophone citoyen in Le français dans le monde, Numéro 302, janvier, fév.1999.

OUDET, B Multilingualism on the Internet apud Contenus québécois sur le Web : Artisanat ou industrie? 1997. Disponível em 14.10.07 em http://www.cyberie.qc.ca/etude/22.html

OLIVEIRA, J.B.A.E Lereis como Deuses: a Tentação da Proposta Construtivista Revista Sinais Sociais. N. 1, Ano 1, pp. 146-178, Maio-Agosto de 2006. Disponível em http://www.alfaebeto.com.br/documentos/artigo_lereis_como_deuses.pdf Acessado em 13.09.07.

OLLIVIER, C Approche actionnelle et tâches en FLE 2006 Disponível em http://eurofle.files.wordpress.com/2006/12/approche_actionnelle_2.ppt Consultado em 28.09.08.

OLLIVIER, C Ecriture, Internet et autonomie de l'apprenant : Aspects de la didactique developpée par le projet DidacTIClang. 2007. Disponível em 
http://eurofle.files.wordpress.com/2007/01/autonomie_internet.pdf Consultado em $\underline{28.09 .08 .}$.

OLLIVIER, C Perspective actionnelle et intégration d'Internet : Développer des compétences grâce à l'intégration d'Internet dans une perspective actionnelle de l'apprentissage des langues, Atelier animé à la 1ère rencontre Disusión FLE, Barcelone, 17 novembre 2006. Disponível em http://eurofle.wordpress.com/2006/11/13/integrer-internet-dans-une-perspectiveactionnelle/ Consultado em 28.09.08.

Parâmetros Curriculares Nacionais : terceiro e quarto ciclos do Ensino Fundamental (1998) Secretaria de Educação Fundamental. Brasília : MEC/SEF Disponível em 14.10.07 em www.ceunes.ufes.br/downloads/PDEEnsino\%20Fundamental\%20-\%20PCNs\%20-\%20temas\%20transversais.pdf

PCN +, E n s i n o M é d i o: Linguagens, Códigos e suas Tecnologias Orientações Educacionais Complementares a os $P$ a râme tros $C$ urriculares $N$ aciona $i s$.

PENDANX, M. Les activités d'apprentissage en classe de langue, Collection Autoformation, Paris, Hachette FLE, 1998.

PEREIRA, A. O que é Internet in Aprenda sozinho Internet agora, lição 11,. Disponível em http://www.aisa.com.br/oquee.html Acessado em 21.08.04. 
PERRENOUD, P. Compétences, solidarité, efficacité : trois chantiers pour l'école in Actes du congrès L'école chrétienne et les défis de notre temps, Bruxelles, Secrétariat général de l'enseignement catholique, pp. 24-45, 1998. Disponível em http://www.unige.ch/fapse/SSE/teachers/perrenoud/php_main/php_1998/1998_23.rtf Cyberdémocratisation : Les inégalités réelles devant le monde virtuel d’Internet In La Revue des Échanges (AFIDES), Vol. 15, n² 2, pp. 6-10, juin 1998. Disponível em http://www.unige.ch/fapse/SSE/teachers/perrenoud/php_main/php_1998/1998_04.html Acessado em 13.10.06.

Pesquisa sobre o uso das Tecnologias da Informação e da Comunicação no Brasil : TIC Domicílios e TIC Empresas 2007 Coordenação executiva e editorial Mariana Balboni. São Paulo : Comitê Gestor da Internet no Brasil, 2008. Disponível em http://www.cetic.br/tic/2007/indicadores-cgibr-2007.pdf Consultado em 19.10.08. TIC Domicílios 2007 : Habilidades com o Computador e a Internet Destaques Disponível em http://www.cetic.br/usuarios/tic/2007/destaques-habilidadesna-internet-tic-2007.pdf Consultado em 24.10.08.

PHẠM ĐỨC SỬ : Lire en FLE Problématiques générales et questions propres au secondaire vietnamien, Thèse de Doctorat en Sciences du Langage, à l'Université de Rouen. Directeur de recherche : Madame Régine DELAMOTTE-LEGRAND. soutenue en septembre 2001. Disponível em http://refef-asie.org/document/Volume\%201.pdf Acessado em 13.08.07. 
PIETRARÓIA, C.M.C. Questões de leitura: aspectos práticos e teóricos da leitura em francês língua estrangeira. São Paulo : Annablume, 2001. (Coleção Parcours)

Percursos de leitura : léxico e construção de sentido na leitura em língua estrangeira. São Paulo, Annablume, 1997.

PLATTEUX, H. Que retirer de l'histoire du livre? in Apprentissage et navigation dans les multimédias éducatifs Université de Fribourg, Centre NTE et Département de pédagogie Cours de pédagogie -Second cycle 2001-2002. Session du 21 janvier 2002. Disponível em http://nte.unifr.ch/IMG/pdf/courshp20012002 session020121.pdf Consultado em 20.10.08.

PORTINE, H. Le multimédia dans la méthodologie de la didactique des langues in Ateliers: Outils multimédias et stratégies d'apprentissage du français langue étrangère, tome I, Cahiers de la Maison de la Recherche, Université Charles de Gaulle, Lille III 19 p, 1996 Disponível em http://www.ac-nancymetz.fr/enseign/allemand/adeaf/ABLAD/DOCSD/LILLECOL.HTM Consultado em 17.11.08.

POTH, J.Éloge du plurilinguisme Propos recueillis par Araceli Ortiz de Urbina.

Courrier de l’UNESCO. Avril 2000. Disponível em 14.10.07 em http://www.unesco.org/courier/2000_04/fr/doss21.htm

POTHIER, M. Multimédias, dispositifs d'apprentissage et acquisition des langues, Paris : Ophrys. 2003. (Collection Autoformation et Enseignement Multimédia). 
POTOLIA, A. ; MOCHET, M.A. Mutations des supports, mutations des pratiques, in Revue Le français dans le monde Apprentissages des langues et technologies: usages en émergence, Paris: Cle International, FIPF, Janvier 2002.

POUTS-LAJUS, S. Une question impossible Ac-TICE, revue interacadémique, 2001. Disponível no site do Observatoire des technologies pour l'éducation en Europe (OTE) em http://www.txtnet.com/ote/Une\%20question\%20impossible.htm Acessado em 09.08.07.

L'ordinateur n'est pas utile à l'éducation, il est nécessaire ! Les

Dossiers de l’Ingénierie Éducative, № 50, mars 2005. Disponível em http://txtnet.com/OTE/DIE-Usages-SPL2.htm Acessado em 02.11.08.

Wikipédia, une encyclopédie sans auteurs ? Les dossiers de

ingénierie éducative : Ressources en ligne, $\mathrm{n}^{\circ}$ 58, juin 2007, pp.26-28. Paris, CNDP. Disponível em 23.05.08 em http://www.weblettres.net/ar/articles/7_122_330_poutsdie58.pdf

PUGIBET, V. Multimédia et civilisation in TARDIEU, C. ; PUGIBET, V. Langues et culture : les TIC, enseignement et apprentissage Colloque des IUFM du Pôle Ile-deFrance (11-12 Décembre 2003). CRDP de Bourgogne, 2004. 
PUREN, C. La didactique des langues face à l'innovation technologique, Actes des colloques UNTELE, Université de Technologie de Compiègne, vol. 2, p. 1-13, 2001. Disponível em 23.05.08 em http://www.utc.fr/ untele/volume2.pdf

Environnements numériques et cohérence didactique in BUFE, W. ;

GIESSEN H.W. Des langues et des médias Grenoble : Presses Universitaires, 2003.

REZEAU, J. Profils d'apprentissage et représentations dans l'apprentissage des langues en environnement multimédia, in ALSIC Vol. 2, numéro 1, pp 27 - 49, juin 1999. Disponível em http://alsic.u-strasbg.fr/Num3/rezeau2/alsic_n03-rec2.htm Acessado em 09.08.07.

RHÉAUME, J. Hypertextes et médias multiples pour l'apprentissage : les nouveaux enjeux de la mise en réseau, Québec : Université Laval, Sainte-Foy. Disponível em www.fse.ulaval.ca/ext/cipte/coll/col95/prog.html Acessado em 13.10.06.

Les divers pourquoi des TIC, notamment en éducation Québec : Université Laval, Médiathic. Disponível em http://www.fse.ulaval.ca/mediatic/atelier/buros/whytic.htm. Acessado em 23.05.08.

L'information: entre l'abondance et la rareté Quebec, Université Laval, Faculté des Sciences de l'Education, (2001). Disponível em http://www.fse.ulaval.ca/mediatic/atelier/buros/rarinfo.htm Acessado em 10.11.08. 
Technologies intellectuelles Quebec, Université Laval, Faculté des Sciences

de l'Education, s.d. Disponível em http://www.fse.ulaval.ca/mediatic/app/app1.htm Acessado em 31.10.06.

RIEDWEG, B \& TRINCHAN V., Hypertextes et genres textuels, Disponível em http://tecfa.unige.ch/etu/E72b/99/trinc_riedw/page_accueil.htm

ROUET, J.-F. Hypermédias et individualisation des appretissages: quels prérequis cognitifs? in Revue Le français d'aujourd'hui, Ordinateur et textes:une nouvelle culture ?, no. 129, Association Française d'Enseignants de Français, Paris, mars 2000.

ROUET, J.-F. Cognition et Technologies d'Apprentissage 2001 Disponível em http://tecfa.unige.ch/tecfa/teaching/aei/papiers/HA-Rouet2001.pdf Consultado em 10.11.08.

ROUET, J.-F. Technologies de l'Information, Lecture et Apprentissages au Cycle 3 Les journées de l'ONL, janvier 2001. Disponível em http://onl.inrp.fr/ONL/publications/publi2001/lecture8-11/ Acessado em 13.09.07.

ROUET, J.-F. La comprehension de documents electroniques in GAONAC'H, D., FAYOL, M. (coord.) Aider les élèves à comprendre : Du texte au multimédia. Paris : Hachette, 2003. Disponível em www.mshs.univpoitiers.fr/laco/Pages_perso/Rouet/Textes/rouetv3.pdf Consultado em 11.11.08. 
ROUSSEL-RAUFASTE, S. Lecture et processus de reconnaissance de mots: Quels sont les processus mentaux qui interviennent au cours de la lecture? 2006. Disponível em http://sophie.raufaste.free.fr Acessado em 07.10.07.

ROUSSEY, J.-Y. ; BARBIER, M.-L. ; PIOLAT, A. Aide à la recherche d'informations sur support hypermedia et prodution écrite par de jeunes rédacteurs Cinquième colloque « hypermédias et apprentissages » : Grenoble du 9 au 11 avril 2001. Disponível em www.up.univmrs.fr/wpsycle/documentpdf/documentpiolat/Publications/RousseyBP2002.pdf Acessado em 13.10.06.

RUI, B. Exploration de la notion de 'stratégie de lecture' en français langues étrangère et maternelle, Acquisition et Interaction en Langue Étrangère [Aile], n.13 - La Lecture en langue étrangère, 2000. Disponível em http://aile.revues.org/document387.html Acessado em 27.08.07.

SERRES, L.DE Paramètres pour une efficacité accrue de la lecture hypertextuelle en langue seconde. Apprentissage des langues et systèmes d'information et de communication (ALSIC), vol. 7, 1, novembre 2004, pp. 131-152.Disponível em http://alsic.u-strasbg.fr/v07/serres/alsic_v07_07-pra3.htm Consultado em 23.10.08.

SERRES, M. La rédemption du savoir , Propos recueuillis par Luis Join-Lambert et Pierre Klein “Des autoroutes pour tous”, in revue Quart Monde, no 163, mars 1997. Disponível em http://agora.qc.ca/textes/serres.html Acessado em 20.08.04. 
SIMMONS, M.; DECOO, W. Comment vaincre l'anxiété en classe de langue ?, in Le Français dans le monde, N³52, Paris : FIPF, Clé International, Juillet-août 2007 Disponível em http://www.fdlm.org/fle/article/352/simonsdecoo.php Acessado em 17.11.08.

SIQUEIRA E. Não abandone seu filho diante da internet Artigo publicado em $\mathbf{O}$

Estado de São Paulo em 23.11.08. Disponível em

http://www.ethevaldo.com.br/Generic.aspx?pid=386 Consultado em 28.11.08

SMITH, F. Compreendendo a leitura : uma análise psicolingüística da leitura e do aprender a ler Porto Alegre, Artmed, 2003, 2a.reimpr.

SOARES, Magda. Novas práticas de leitura e escrita: letramento na cibercultura, Educ. Soc., Campinas, v. 23, n. 81, 2002. Pré-publicação disponível em http://www.scielo.br/scielo.php?script=sci_arttext\&pid=S010173302002008100008\&lng=pt\&nrm=iso Acessado em: 23.05.08.

SOUCHON, M. Lecture de textes en LE et compétence textuelle Acquisition et Interaction en Langue Étrangère [Aile], n. 13 - La Lecture en langue étrangère, 2000. Disponível em http://aile.revues.org/document1462.html Acessado em 28.09.07.

SOUCHON, M. Pour une approche sémiotique de la lecture-compréhension en langue étrangère, Semen, nº 10, Sémiotique(s) de la lecture. 1995.

Disponível em http://semen.revues.org/document2981.html Acessado em 15.08.07. 
SPRENGER-CHAROLLES, L. Les premiers apprentissages de la lecture et de l'écriture en français. L'apprentissage de la lecture à l'école primaire, rapport $\mathbf{n}^{\circ}$ 2005-123 : Observatoire national de la lecture ; l'Inspection générale de l'Éducation nationale. 2005. Disponível em http://www.bienlire.education.fr/01actualite/document/apprendre_a_lire_Sprenger.pdf Acessado em 13.08.07.

SPRINGER, C. Évaluation de la compétence et problématique de l'acquisition en L2 : Préliminaires pour une définition de profils prototypiques de compétence en L2, in Marges Linguistiques, juillet 2002 Disponível em http://www.revue-texto.net/19962007/marges/marges/000_presentations_art_html/doc0163presentation.htm Consultado em 17.11 .08

TARDIF, J. La contribution des technologies à l'apprentissage : mythe ou réalité conditionnelle in Le français dans le monde : Recherches et applications : Apprentissages des langues et technologies : usages en émergence, janvier 2002, Paris : Cle International, FIPF, pp.15-25.

TOMÉ, M. Français langue étrangère et Internet : 1. L'information : Internet ou la bibliothèque universelle in Thot/Cursus 23-11-1999.Disponível em http://thot.cursus.edu/rubrique.asp?no=2248 Acessado em 19.08.04.

TREBBI, T. L'Internet, un outil à service de l'élève in Les technologies de l'information et de la communication et le projet d'établissement, Poitiers, Assises internationales, 16 et 17 décembre 1998. 
TRICOT , A. Je zappe, j'apprends ? Interview d'André Tricot, propos recueillis par Yves Picard et Marie-Hélène Pillon, CRDP de Bretagne. 2000. Disponível em http://savoirscdi.cndp.fr/archives/dossier_mois/tricot/tricot.htm Consultado em 04.11.08.

TRIM, J. (org.) Guide pour les utilisateurs CADRE EUROPEEN COMMUN DE REFERENCE POUR LES LANGUES: APPRENDRE, ENSEIGNER, EVALUER Strasbourg : Division des Politiques Linguistiques, 2002.

UGUEN, N. Les TICE au service du traitement de l'information Les dossiers de ingénierie éducative, Les TPE, n.34, février 2001, pp. 59-60, Paris : CNDP

VALADE, P. Les technologies de l'information et de la communication entraînentelles des changements dans la dynamique de l'apprentissage? in Mémoire C.A.F.I.P.E.M.F. - Mars 1998. Disponível no endereço http://pedagogie.actoulouse.fr/piquecos/pages/cafiSP.html Acessado em 23.05.08.

VANDENDORPE, C De la lecture sur papyrus à la lecture sur codex électronique conférence au colloque sur « Les futurs possibles du livre », Grande bibliothèque du Québec, novembre 2001. Disponível em http://www.banq.qc.ca/documents/extranet/bibliotheques/documentation/conferences_p resentations/vandendo.pdf Consultado em 21.10.08. 
VANDENDORPE, C La Lecture de l'hypertexte site L'astrolabe : Université d'Otawa, 2000. Disponível em http://www.uottawa.ca/academic/arts/astrolabe/articles/art0006.htm/Lecture.htm\#D'autr es\#D'autres Acessado em 27.10.08.

VANDENDORPE, C Variétés de l'hypertexte in Du papyrus à l'hypertexte. Essai sur les mutations du texte et de la lecture, Montréal, Boréal et Paris, La Découverte, 1999. Disponível no site L'astrolabe em http://www.uottawa.ca/academic/arts/astrolabe/articles/art0005.htm Acessado em 27.10.08.

VANDENDORPE, C L'hypertexte et l'avenir de la mémoire in Le débat, no 115, maiaoût 2001, p. 145-155. Disponível em http://www.lettres.uottawa.ca/vanden/Memoire\&Hypertexte.htm Acessado em 03.11.08.

VEJA Nisso eles são bons... ...mas, na hora de navegar na internet, os adultos é que entendem do riscado Veja, ed. 1896, 16.03.05. Disponível no endereço http://veja.abril.com.br/160305/p_080.html Consultado em 27.09.08.

VIGNER, G. Didactique fonctionnelle du français, Collection F., Hachette, 1980.

VIRILIO, P. A Bomba Informática, São Paulo: Estação Liberdade, 1999. 
WOLTON, D. Internet, e depois? : uma teoria crítica das novas mídias. Porto Alegre, Sulina, 2003.

ZILBERMAN, R. (org.) Leitura em crise na escola. 3.ed. Porto Alegre, Mercado Aberto, 1984.

ZINNA, A (1998) Analyse des discours: textes, types et genres Colloque

International (3-4-5 décembre 1998 à l'Université de Toulouse-Le Mirail)

http://www.fl.ulaval.ca/hst/visio/analyse.htm (Indisponível em 17.11.08). 


\section{Anexos:}

\section{Anexo 1 - Lista de sites propostos para a pesquisa}

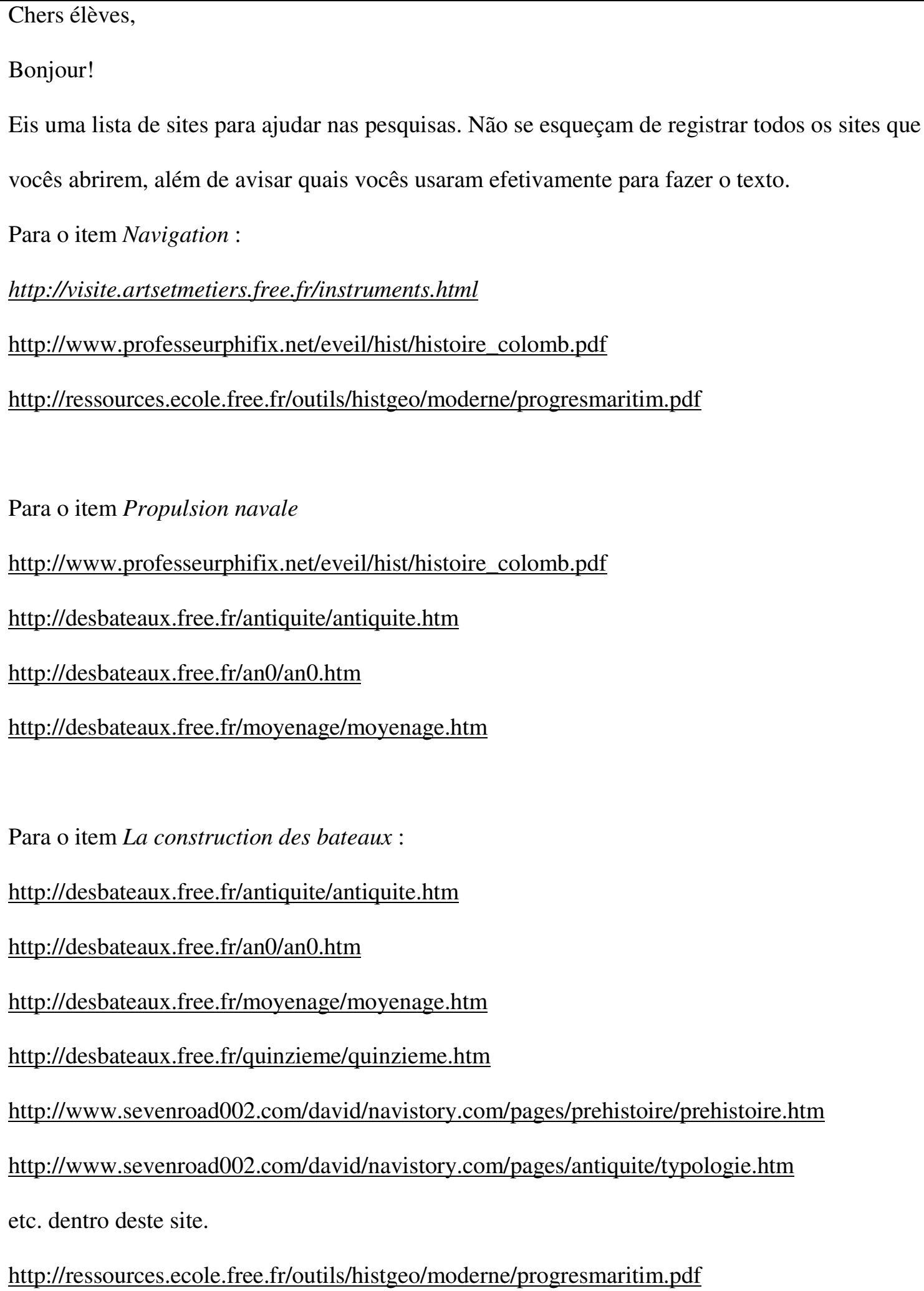


Para o item La cartographie :

http://www.professeurphifix.net/eveil/hist/histoire_colomb.pdf

http://ressources.ecole.free.fr/outils/histgeo/moderne/progresmaritim.pdf

mapa do Brasil séc XVI

http://ressources.ecole.free.fr/outils/histgeo/moderne/cartebresil16.pdf

http://www.contenu.com/ActivitesPedagogiques/visualiser_scenario.asp?noActivite=194

Para o item Les marins

http://www.professeurphifix.net/eveil/hist/histoire_colomb.pdf

http://desbateaux.free.fr/quinzieme/quinzieme.htm

http://www.memo.fr/article.asp?ID=MOD_DEC_002

http://www.memo.fr/article.asp?ID=MOD DEC 003

http://www.memo.fr/article.asp?ID=MOD_DEC 000

Para o item Les finalités de la marine

http://desbateaux.free.fr/antiquite/antiquite.htm

http://desbateaux.free.fr/an0/an0.htm

http://desbateaux.free.fr/moyenage/moyenage.htm

http://desbateaux.free.fr/quinzieme/quinzieme.htm

http://www.memo.fr/article.asp?ID=MOD_DEC 002

http://www.memo.fr/article.asp?ID=MOD DEC 003

http://www.memo.fr/article.asp?ID=MOD_DEC_004

etc.

La pêche

http://www.heritage.nf.ca/patrimoine/exploration/fpres international_f.html 


\section{Anexo 2 - Entrevista com os alunos}

Entrevistas realizadas em 2404 08. Não houve condições de gravar as entrevistas, elas foram apenas anotadas pela professora; por isso não há uma transcrição com o padrão da análise da conversação, mas apenas uma transcrição de tipo jornalístico.

Angel e Mariana

Professora: Como está a compreensão dos textos que vocês estão lendo?

Angel: Tá razoavelmente razoável para entender, entendeu? A Mariana procurou e a gente usou aquele site.

Mariana: Procurei um tempão, um tempão, aí me deu na cabeça procurar "histoire de la cartographie"

Professora: Pesquisou como?

Mariana: No Google, normal, sem opção francês, só com a frase.

Professora: Por que escolheram esse site?

Angel: Esse site tem bastante conteúdo.

Mariana: Bastante conteúdo e bastante imagem. A gente não precisou procurar imagem.

Professora: Como vocês leram?

Angel: Com a ajuda da professora.

Mariana: Tudo a gente perguntava...

Professora: Não é verdade!

Mariana: É que o texto não é muito difícil. Só o que a gente não entendia é que a gente perguntava...

Professora: Como dividiram os slides?

Mariana: Como assim?

Angel: Nós seguimos o texto. 
Professora: Vocês puseram tudo ou resumiram?

Angel: Nós resumimos.

Mariana: Nós fomos pulando o que não era importante.

Professora: Como vocês sabiam (o que era importante?)

Mariana: Perguntava para a professora.

Professora: Tem certeza? Ou vocês distinguiam?

Angel: A gente pegava o principal.

Mariana: Traduzia e pegava o mais importante.

Professora: Não tem um jeitinho de saber o que é mais importante?

Angel: A gente pegava o principal.

Mariana: $O$ que não influenciava a gente descartava.

\section{Caroline e Karysa}

Professora: Como está para entender?

Carol: Tá médio, não tá difícil mas não tá fácil.

Karysa: Dá pra entender o contexto, mas não dá para traduzir todas as palavras.

Professora: Mas para que traduzir?

Carol: Para entender. A gente vai colocar coisa sem entender?

Karysa: Para saber o que a gente está colocando.

Professora: Por que escolheram aquele site?

Karysa: Ele tem informações melhores.

Carol: É melhor para resumir o texto.

Professora: Como é que vocês sabem?

Carol: A gente pesquisou primeiro na Wikipédia, porque sempre tem coisas. Depois nos que a professora indicou.

Karysa: Porque a professora indicou. 
Professora: Como vocês leram?

Carol: No Babel Fish ou com a professora.

Professora: Tudo ou resumido?

Carol e Karysa: Resumimos.

Karysa: Tentava pegar o mais importante

Carol: Primeiro pegava o mais importante e ficava grande. Aí a gente pedia a ajuda da professora.

Professora: Como sabem o que é mais importante?

Carol: $O$ mais de acordo com o tema que a gente escolheu.

Professora: Então vocês entendiam?

Karysa: Mais ou menos. O que a gente não entendia perguntava para a professora.

Carol: Eu entendi bastante, mas não tudo.

Professora: Vocês têm mais alguma coisa a dizer?

Carol: As figuras eram bonitinhas... Não, fessora, não coloca isso! (risos)

Karysa: Não. Nada a dizer.

\section{Danillo e Akira}

Professora: Como está para entender os textos?

Danillo: Está mais ou menos.

Akira: Dá para entender razoavelmente bem.

Professora: Como vocês encontraram?

Akira: Usando primeiramente o Google. Abri um monte de sites e escolhi um pelo título geral do texto.

Professora: Um para ler?

Akira: É, para ler, para ver se tinha o que eu queria.

Professora: E depois?

Akira: Dei uma lida geral, traduzi uns pontos,,, 
Danillo: Ele traduziu no Babel Fish.

Akira: Nada a ver, mentiroso.

Danillo: Eu traduzi. Em casa, sim.

Professora: E aí?

Akira: A partir da lida geral, peguei as idéias gerais que me interessavam e produzi o resumo para colocar no Power Point.

Danillo: Eu colocava no Babel Fish para entender alguma coisa.

Professora: E as imagens?

Danillo: Procurei em vários sites.

Akira: Mas teve que modificar brilho, contraste.

\section{Stella e Jéssica}

Professora: Como vocês estão fazendo para entender?

Stella: É assim: "Professora, o que é isso?"

Jéssica: Ou a gente pega um tradutor ou a gente pergunta para a professora.

Professora: Então vocês entram no tradutor?

Stella: Para ser bem sincera, eu nunca entrei no tradutor. Dá para entender [o texto], você ignora algumas palavras...

Professora: E você entrava?

Jéssica: Ah, quando a frase estava muito difícil, eu entrava.

Professora: E ajudava?

Jéssica: Não muito.

Professora: Como escolheram o texto que vocês estão usando?

Stella: A gente perguntou para a professora e ela indicou. Aí a gente abriu.

Professora: Qual é o texto mesmo?

Stella: É o “ba-te-a-u”. Não, estou brincando, é “bateau”. É Google, pesquisa avançada, “bateau”.

Professora: Com francês ou não?

Stella: Com francês.

Professora: E aí, deu para entender? 
Stella: Deu.

Professora: Como vocês resumiram?

Jéssica: A gente tentou traduzir...

Stella: A gente não conseguiu, a gente pegou as primeiras linhas. Aí a professora disse que estava errado e ela corrigiu para a gente. Ah, isso aí é para o seu mestrado?

Professora: Sim.

Stella: Aí Jéssica, vamos falar que estava ótimo senão a professora nunca vai ser mestra. "Olha, tava ótimo!” (risos)

Professora: Não, não, só a verdade! Como vocês dividiram os slides?

Stella: A gente pegou entre as categorias de finalidades.

Professora: Como descobriram as finalidades?

Stella: Já estava no sumário, a gente foi só clicando.

Professora: E dava para entender?

Stella e Jéssica: Dava.

Jéssica: Até eu consegui entender!

Stella: A gente não descobriu o que era "bateau de loisir”, mas a gente continuou sem saber o que era. A gente pôs lá, achou uma foto.

Professora: Sem saber, como é que vocês acharam a foto?

Jéssica: Bom, a gente viu a foto e descobriu que era alguma coisa de passeio.

Professora: Então, e para resumir?

Stella: A gente não lia o texto inteiro, a gente só lia as primeiras linhas, selecionava e depois a professora tirava um роисо.

Professora: E o outro site? Eu não pedi dois sites?

Stella: $O$ outro não tinha nada. 
Jéssica: A gente não conseguiu entender, então pegou na Wikipédia mesmo.

Professora: Vocês têm algo mais a dizer? O que vocês estão achando do trabalho?

Stella: A gente não acabou ainda.

Jéssica: A parte que a gente fez estava bom.

Stella: Merci, à tout à l'heure.

\section{Gabriela e Inês}

Professora: Como está para entender a leitura?

Inês: Do texto?

Gabriela: Dá para entender.

Professora: Então está fácil?

Inês: A gente sabe do que o texto está falando, então o que a gente não sabe a gente imagina. Dá para entender.

Professora: Então você entende pelo contexto?

Inês: É.

Gabriela: É assim, como a gente já sabe o que o tema está tratando, a gente não chuta fora. A gente sabe dos limites que o tema traz.

Professora: Aí você chuta com base, é isso?

Gabriela: Hum, hum.

Professora: Mas para chutar, você tem um exemplo?

Inês: Que eu chutei?

Professora: Sim.

Inês: Eu estava sem o caderno, então não anotei as dúvidas. Mas aquele texto é fácil!

Professora: Um exemplo?

Gabriela: Só pegando o texto.

Inês: Era muito fácil.

Professora: Que bom! Como vocês escolheram o texto para ler? 
Gabriela: Depois de pesquisar no Google e não achar nada, resolvemos partir para os links que a professora mandou. Mas acabei usando para começar um site que não estava nos links.

Inês: Eu fui direto aos links e achei um lá que tinha tudo. O "Des bateaux".

Professora: E para resumir?

Inês: Bom para resumir, eu não usei minhas palavras porque eu não sei. Eu vi as frases mais importantes e tirei o resto. Quer dizer, a professora disse que era para resumir.

Gabriela: Também tentei pegar as frases mais importantes (...)

Gabriela: (...) e os pedaços que estavam mais difíceis, apesar de eu odiar fazer isso, eu coloquei no tradutor.

Professora: E o resultado foi bom?

Gabriela: Não muito.

Inês: Algumas coisas não tinham nada a ver. O tradutor copia a palavra às vezes, na língua que tá, não traduz.

Gabriela: O tradutor é burro, mesmo.

Inês: O site em que eu tava é fácil mesmo. Tem uma ou outra palavra que eu não sei. É básico mesmo. É pra pessoas que não conhecem o assunto e querem conhecer.

Gabriela: Um site objetivo.

Professora: E quanto à divisão em slides?

Inês: Bom, pra mim, eu queria fazer poucos slides e eu tive que dividir. Mas por mim... Ainda mais que aquele texto não deixa copiar-colar e eu tive que copiar tudo à mão.

Gabriela: Bom, o que eu fiz foi separar em assunto e quando o assunto foi grande o que eu fiz foi separar em dois slides. Quando o assunto era irresumível...

Professora: Bem vocês querem falar algo mais sobre o processo de leitura?

Gabriela: Razoável.

Inês: Pra mim tá indo bem.

Gabriela e Inês: Brigada, fessora.

Professora: Obrigada a vocês. 


\section{Rogério}

Professora: O que você está achando da leitura?

Rogério: Meio complexa mas dá para encarar.

Professora: Considerando que você nunca tinha visto francês, tá dentro do que você esperava?

Rogério: Eu pensei que seria mais difícil. Mas com o tempo eu percebi que não era um bicho de sete cabeças. Claro que eu tive muita ajuda.

Professora: O que você acha que ajuda para a compreensão?

Rogério: Muita pesquisa.

Professora: De pesquisa?

Rogério: O contexto do texto e um pouco de chute também. Eu acho que só.

Professora: Só chute e contexto?

Rogério: Ajuda da professora.

Professora: E a semelhança das palavras?

Rogério: É bem parecido com o português. Eu não sabia que era tão parecido. Pra mim era umas letras mais diferentes.

Professora: E o tema, o que você achou?

Rogério: Nunca tinha pesquisado sobre isso e foi interessante. Não foi tão difícil.

Professora: Então, você aprendeu alguma coisa?

Rogério: Aprendi.

Professora: Algo mais?

Rogério: Do francês. O francês eu pensava que não tinha tanta coisa na Internet. Não pensei que tinha tantas explicações sobre um assunto só. É só. Foi bem expressado. 


\section{Anexo 3 - Transcrição da Leitura em Voz Alta}

O texto foi retirado do site da Academie de Réunion, tendo sido publicado inicialmente na Enciclopaedia Universalis, no setor reservado aos assinantes, conforme links abaixo:

http://www.ac-

reunion.fr/pedagogie1/circons/port1/site web/boussole/histoirenivigation.htm

Normas seguidas para transcrição: Na coluna das transcrições da leitura em voz alta, o texto em letra padrão corresponde a intervenções da professora, o texto em itálico corresponde ao primeiro aluno mencionado no início da coluna, o texto em negrito refere-se ao segundo aluno, o texto em itálico e negrito transcreve os momentos em que os dois alunos lêem conjuntamente, com as mesmas palavras. As demais normas seguem o padrão do NURC/SP (2001 : 11):

\begin{tabular}{|l|l|}
\hline Incompreensão de palavras ou segmentos & () \\
\hline Hipótese do que se ouviu & (hipótese) \\
\hline Entonação enfática & maiúscula \\
\hline Truncamento & $/$ \\
\hline Prolongamento de vogal ou consoante & $::$ ou ::.:: \\
\hline
\end{tabular}




\begin{tabular}{|l|l|}
\hline Silabação & - \\
\hline Interrogação & $?$ \\
\hline Qualquer pausa & $\ldots$ \\
\hline Comentários descritivos do transcritor & [comentário] \\
\hline
\end{tabular}

Tabela 9: Padrões do NURC/SP para transcrição da conversação.

\section{INSTRUÇÕES PRÉVIAS DA PROFESSORA:}

\section{Para a classe toda:}

cada dupla vai ler um pouquinho tá? em português... para me dizer... para eu saber como é que vocês lêem... entenderam? só para eu saber como é que vocês estão entendendo alguma coisa... certo?... quando vocês não entenderem... uma pergunta para outra ou um pergunta para o outro... e me digam o que que vocês acham... continua... não continua... vamos ver de alguma maneira como é que vocês vão entender... ou passa para adiante... entenderam? é isso que eu quero saber... vale tudo... inclusive perguntar para a professora... entenderam?

\section{Para Gabriela e Inês:}

então tá... vocês vão ler esse texto que está aqui... L'histoire... começa com L’histoire... vamos lá...

Para Karysa e Carolina:

podem ler... cada uma lê um pedacinho? não... não... as duas lêem juntas e discutem o que têm de dúvidas... vocês resolvem juntas o que vocês vão fazer... se vão entender isso... se vão passar para adiante....vocês têm que se ajudar... entendeu? tá bom... então vai

Para Angel e Mariana

vamos tentar novamente a gravação da Angel e da Mariana [pois a primeira gravação desta dupla e da dupla Jéssica e Stella, assim como de Akira e Danillo não pode ser aproveitada por problemas técnicos]... qualquer dúvida... vocês discutam entre si ou vocês me perguntam... ta certo? então vamos lá

Para Akira e Danilo

aqui está::: a leitura de Akira e Danilo... Akira é esse daqui e Danilo é aquele ali... não dá para você ver, né? mas tudo bem... vamos lá:: ao trabalho... 


\begin{tabular}{|c|c|c|c|c|c|}
\hline 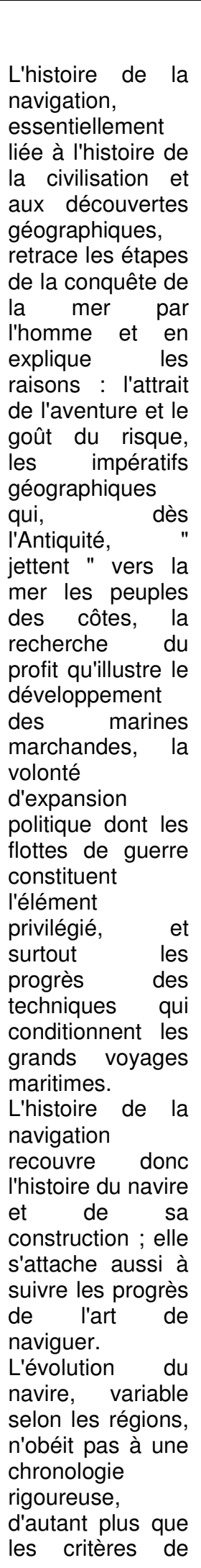 & 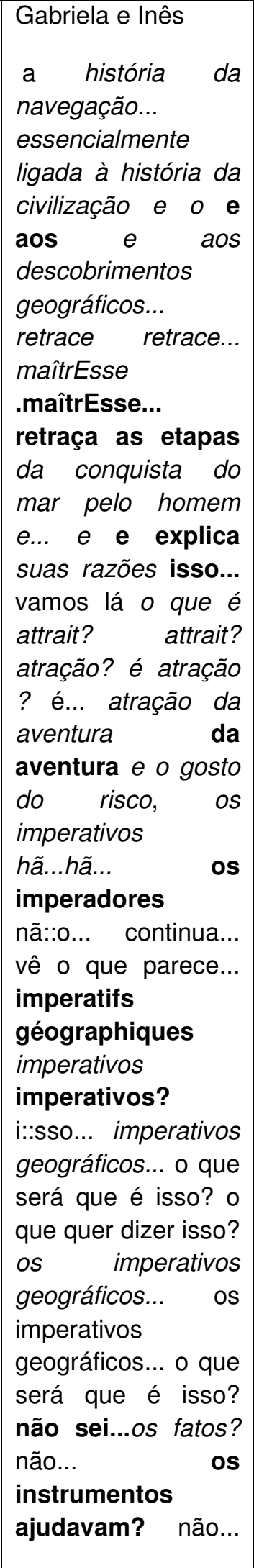 & 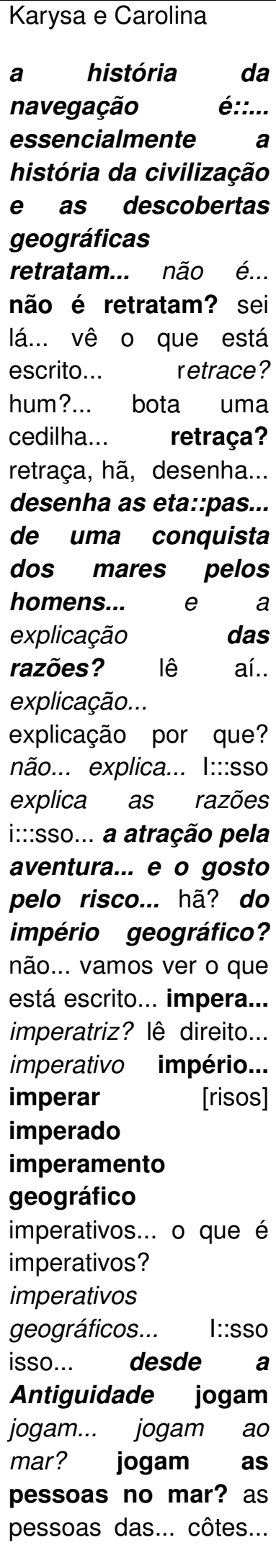 & 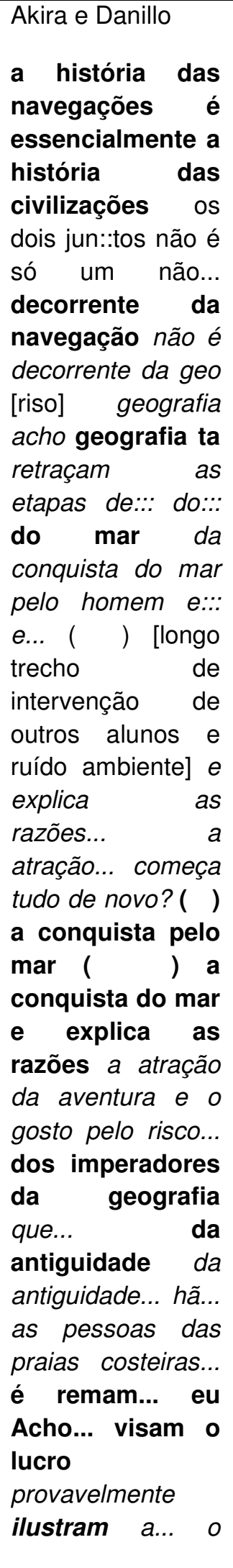 & 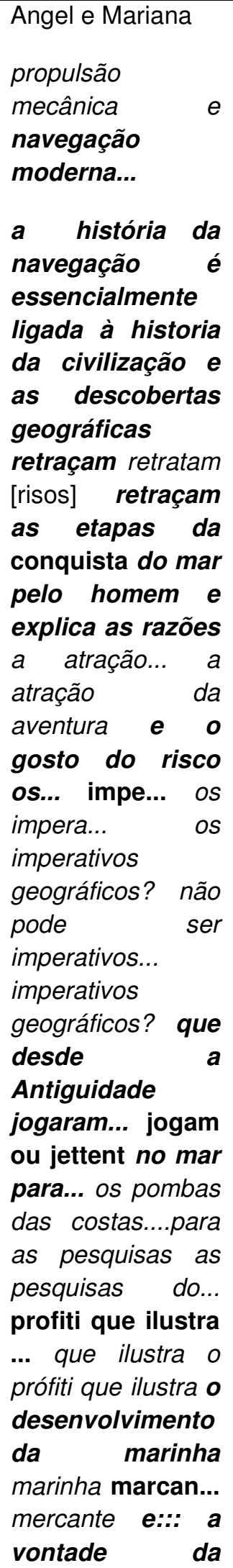 & 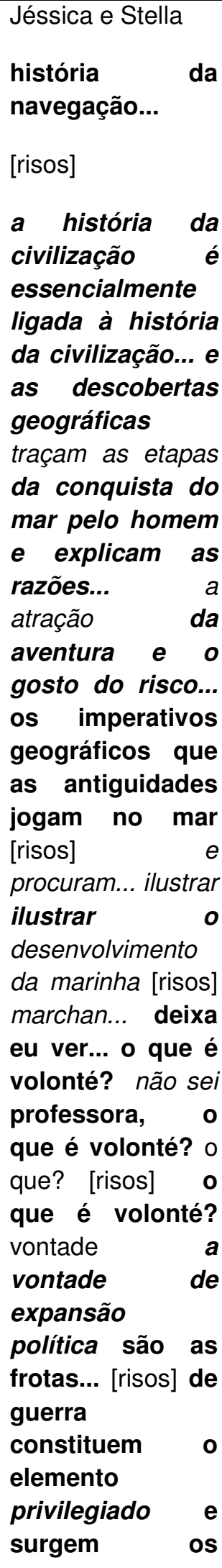 \\
\hline
\end{tabular}




\begin{tabular}{|c|c|c|c|c|c|}
\hline 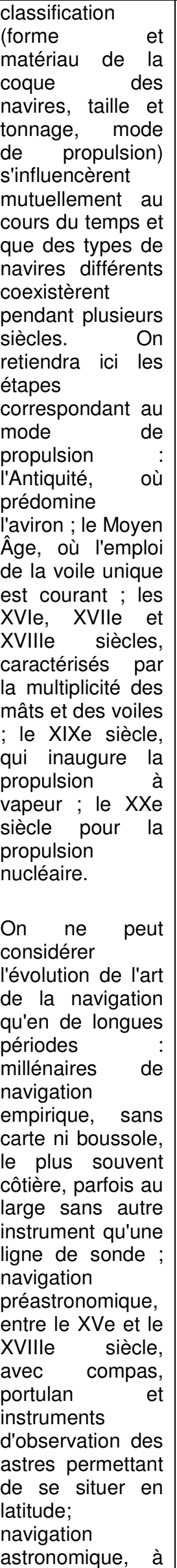 & 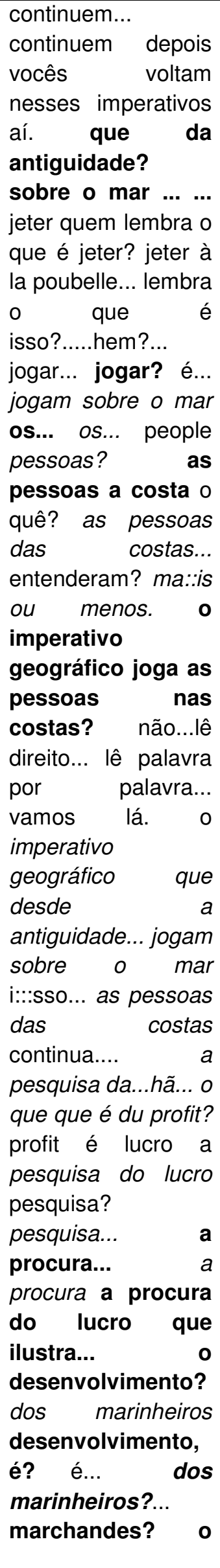 & 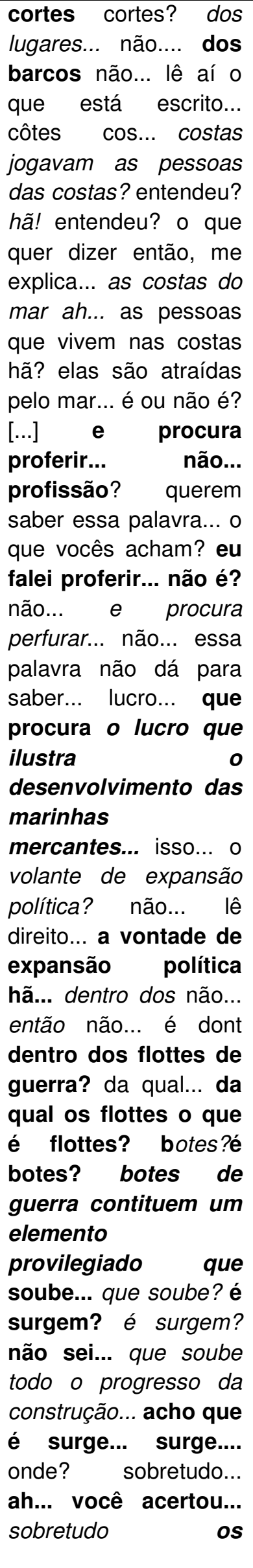 & 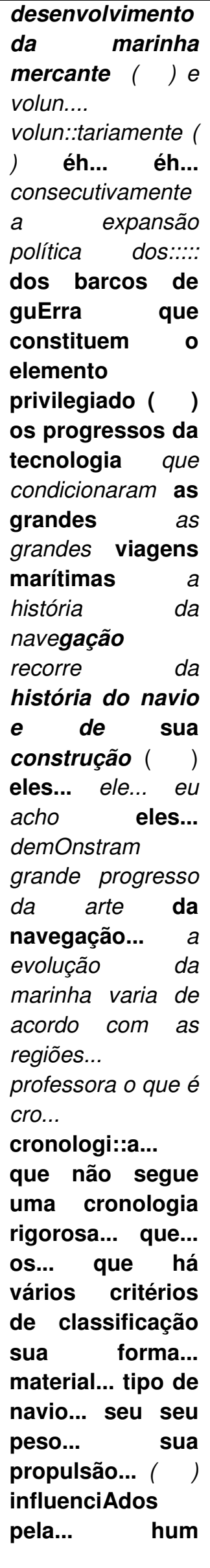 & 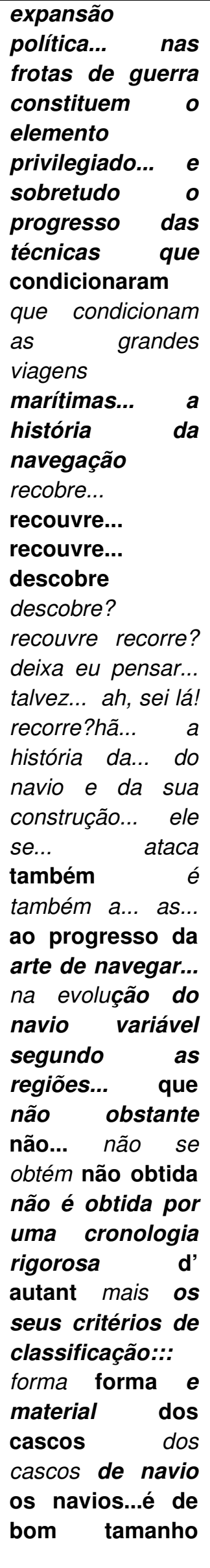 & 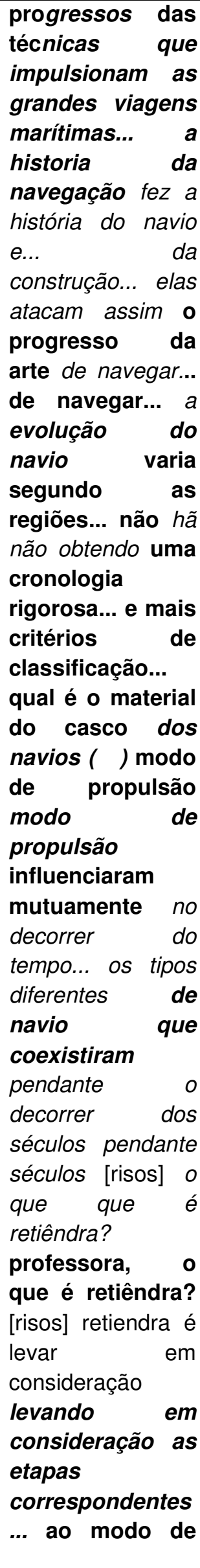 \\
\hline
\end{tabular}




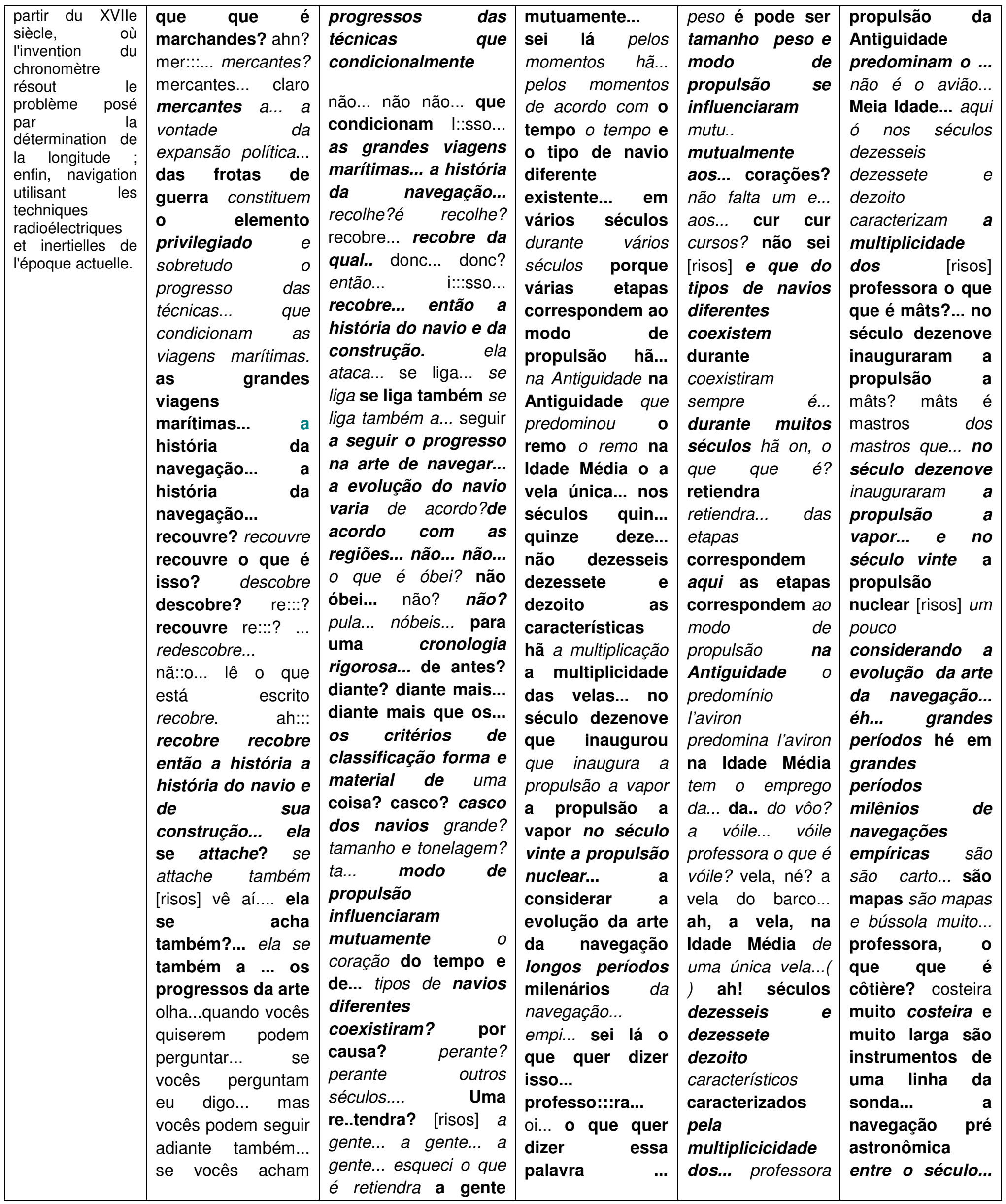




\begin{tabular}{|c|c|c|c|c|}
\hline 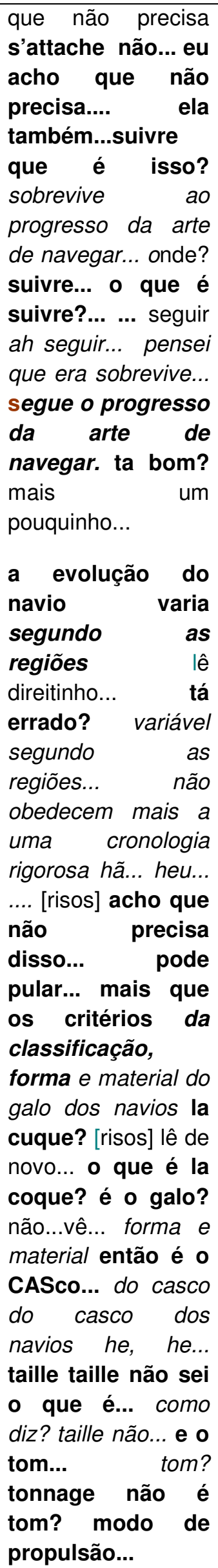 & 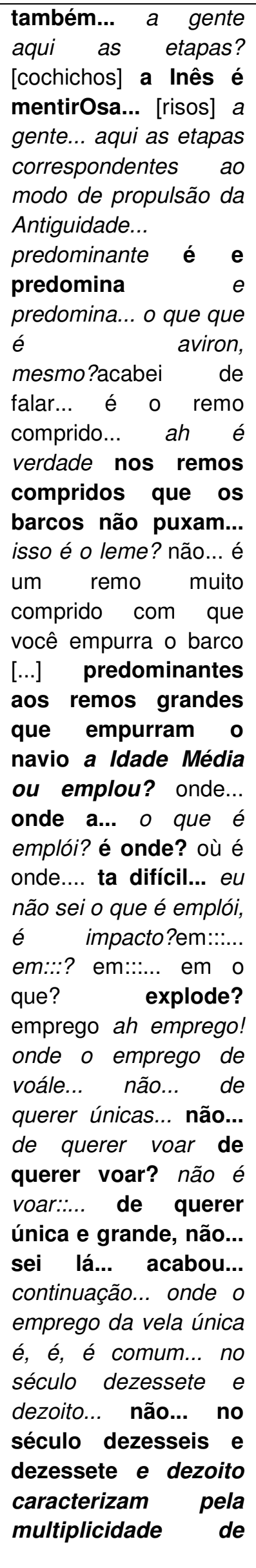 & 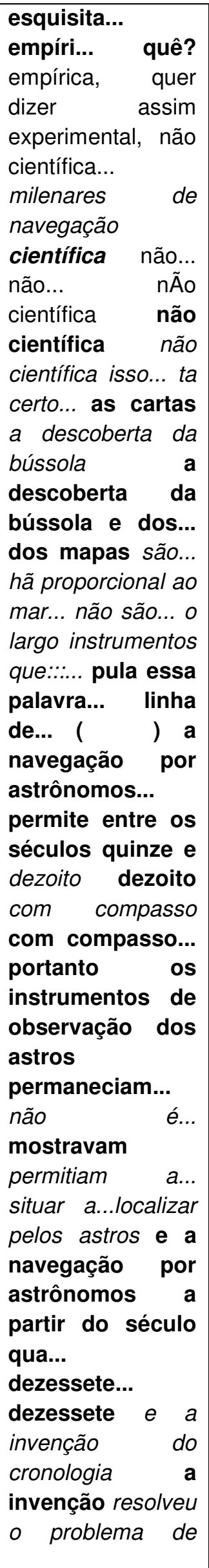 & 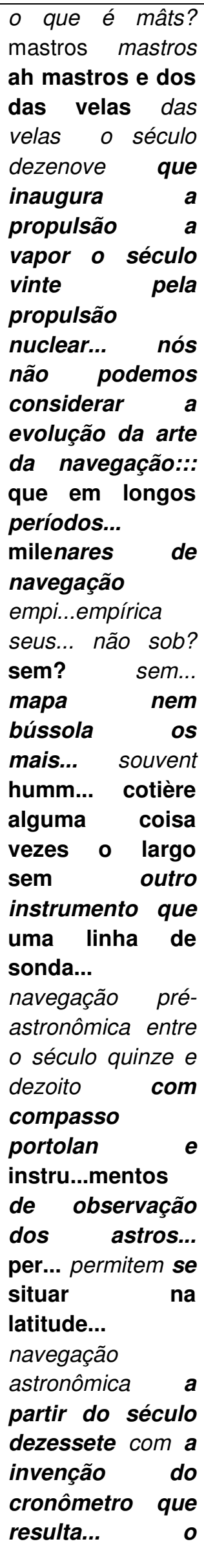 & 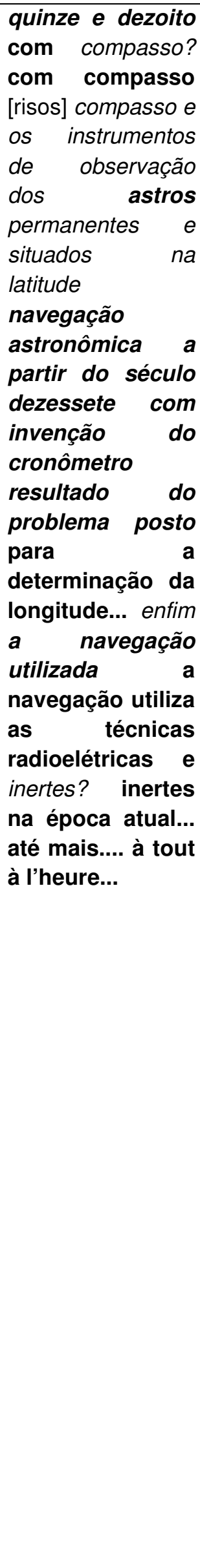 \\
\hline
\end{tabular}




\begin{tabular}{|c|}
\hline 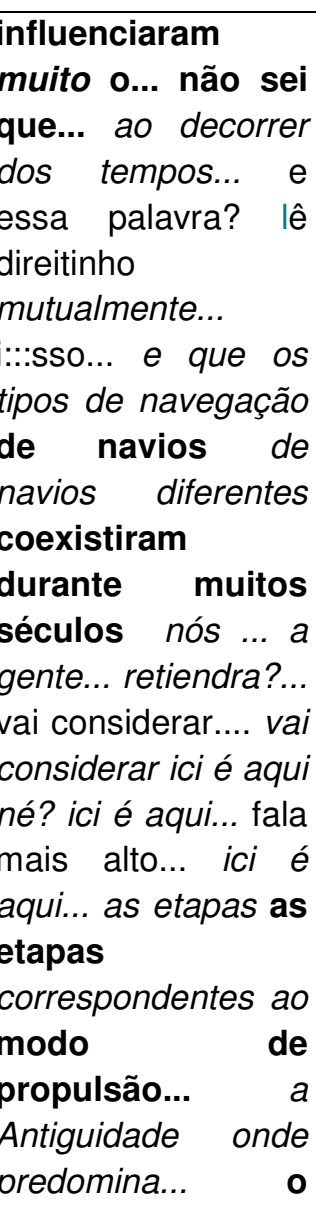 \\
\hline
\end{tabular}

aviron 0 aviron? quem sabe o que é aviron? por volta... pergunta para quem sabe... não é por volta? quem lembra o que é a-viron?

[Akira: avião?] nã::o é uma coisa de barco... está falando do mar e é o avião??? [A Akira] você que falou das coisas do barco ... ta falando a tradução aqui.... [Akira: taí, taí ] continua taí mesmo.... olha... aviron é o remo comprido... alguém de vocês sabia? vocês que procuraram? 0 aviron é aquele hum... mais? lê de determinação da novo.... multiplicidade longitude enfim a de mastros e velas... navegação

ah... 0 século

dezenove inaugura a propulsão a vapor... o século vinte a propulsão nuclear [...] não acabou ainda... onde um pouco... não... não é pouco...hã... volta... onde está onde? não tem onde... on, on 0 que é on? o que é peuti? não sei... recomeça... recomeça a frase e vão embora... onde se considera a evolução... dentro? considera a evolução da arte da navegação de

percursos... milenares da navegação em? pitocada? [risos] não empregadas? não... vê o que está escrito... empíricas, é empíricas mesmo? o que é isso? milenares da navegação empírica são cartas na bússola e mais... cordas... sendo outro instrumento uma linha de sonda... a navigação préastronômica entre 0 século quinze $e$ dezoito com compras não é compras... com cômpas em francês, $O$ que é cômpas, professora?...compás? Compasso... portolan os instrumentos de observação dos astros permitem... situação situar... situar a latitude a (utilitária)

radioelétricas e inércias da época atual já era acabou... fi::nish

.

é

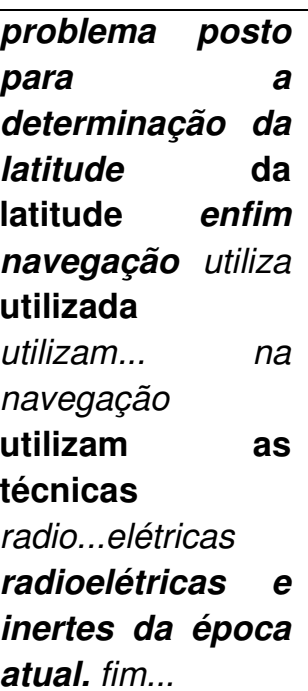

atual. fim... 


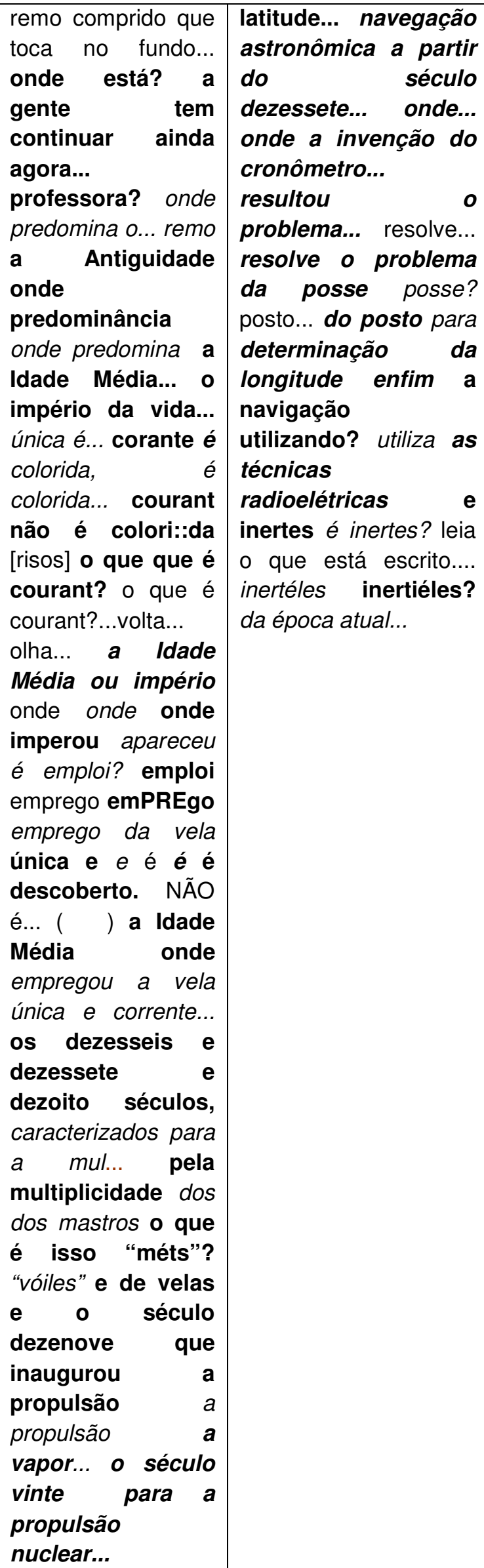




\begin{tabular}{|c|c|}
\hline 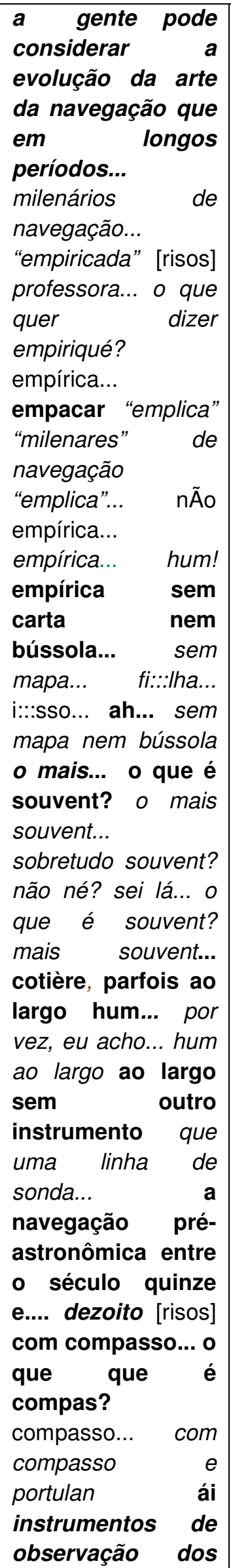 & \\
\hline
\end{tabular}




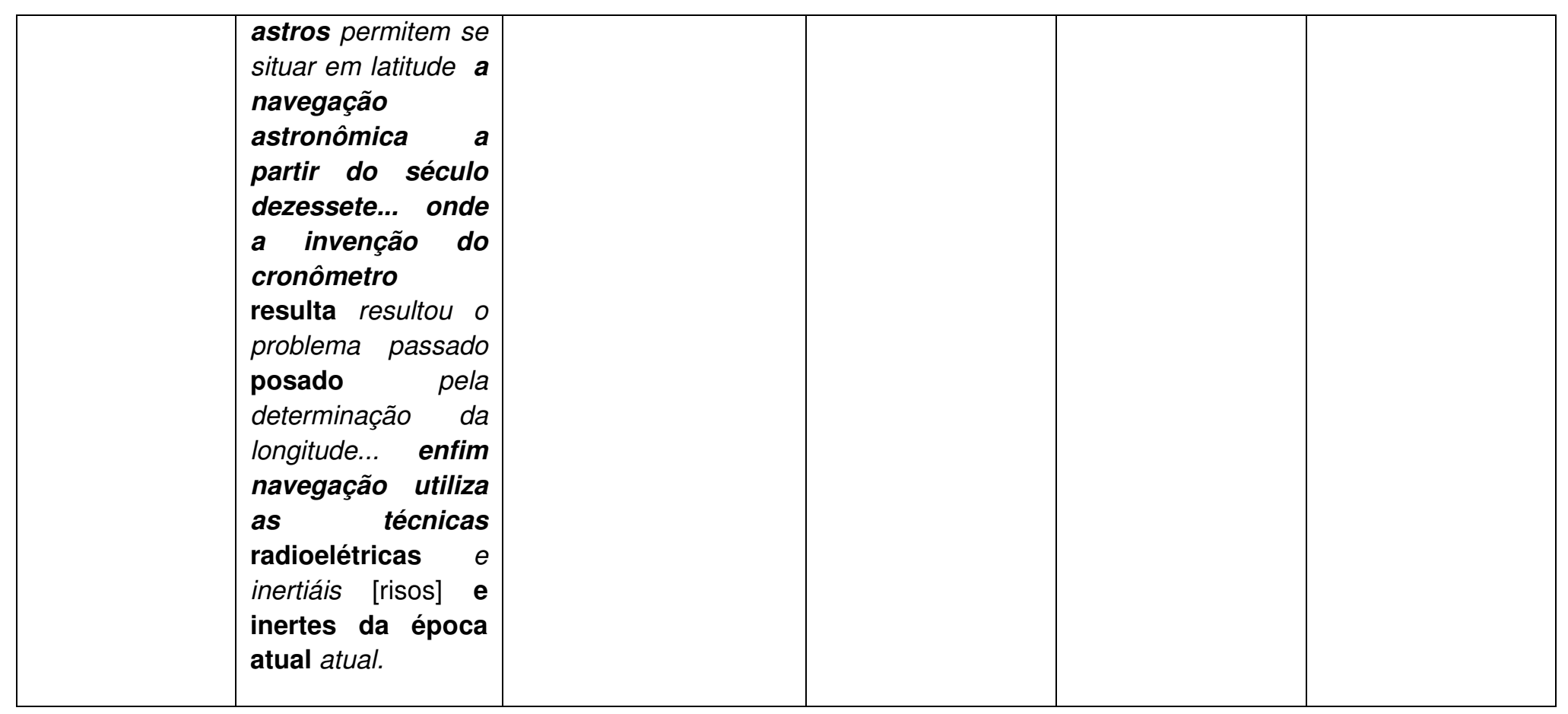




\section{Anexo 4 - Entrevista com a Diretora do Colégio}

Transcrição da entrevista gravada em 06.05.08, com Maria Ivone Pereira de Miranda Fedeli, diretora do Colégio São Mauro.

- Qual é o papel dos Projetos Interdisciplinares de Leitura em FLE no projeto pedagógico do Colégio?

- Em primeiro lugar, é preciso notar que a nossa escola não é uma escola que trabalhe exclusivamente com projetos. Nós temos, ao contrário, um programa de conteúdos que devem ser estudados ao longo de cada um dos anos escolares. Mas, por outro lado, nós consideramos que os projetos são importantes, na medida de possibilitar uma aplicação mais prática e mais imediata de conhecimentos adquiridos. E exatamente por ser uma aplicação mais prática e mais imediata, gera-se um interesse com uma maior facilidade e isso - é claro, todos nós sabemos o quanto a questão do interesse é importante no aprendizado efetivo. Então, embora nós não sejamos uma escola que só trabalha com projetos, nós consideramos os projetos importantes no total do aprendizado deles. E por isso nós repetimos, ao longo do ano, vários eventos, em que projetos diferenciados, inclusive projetos de várias áreas, muitos deles interdisciplinares, são trabalhados. E possibilitamos grandes ocasiões pedagógicas em que há a oportunidade de montar esses projetos e de apresentá-los (---).

- Como funcionam esses eventos, dos quais essa Feira de História?

- Então, justamente, essas Feiras, elas têm vários objetivos, para nós. E eu falo primeiro daquele que é menos importante, embora no total da vida escolar não seja desimportante. Porque um aspecto social importante da escola, mas que também está envolvido em toda questão pedagógica, é a participação dos pais, a participação da família, a participação até da comunidade do bairro, de tudo aquilo que envolve a escola. Então todo educador sabe muito bem a dificuldade que é trazer os pais para a escola, naquilo que se convencionou chamar as 
Reuniões de Pais e Mestres. Para eliminar um pouco essa dificuldade de trazer os pais nessas ocasiões, nós fazemos um trabalho conjugado. Nós temos - a nossa escola funciona por bimestres, as avaliações são sistemáticas por bimestre - então em todo bimestre nós temos uma Reunião de Pais e Mestres. A cada vez que acontece um desses eventos - a Reunião de Pais e Mestres - nós juntamos a isso o que nós chamamos de feiras. Então, no primeiro bimestre nós temos a Clio - Clio era a deusa grega da História e por isso nós chamamos de Clio essa feira que reúne trabalhos de História, de Geografia, mas não só, em que se integram projetos de Língua, eventualmente projetos de Matemática...

- O projeto que nós estamos analisando, o projeto Histoire de la technologie maritime ,é um projeto interdisciplinar, de História e Geografia. Ele fala da tecnologia das navegações e...

- Exatamente, exatamente, ele está inserido nessa Feira Clio, embora ele seja um projeto, ao mesmo tempo, de História e Geografia e de Línguas. Há outros que foram, por exemplo, de História e Geografia e de Matemática, com medições, com todas essas coisas que importam na Geografia.

- De Artes também...

- De Artes... Então nós fazemos a Clio, essa foi a terceira FeClio, depois nós temos a FeLumen, que é a Feira de Ciências, ela é feita com a Reunião de Pais e Mestres do segundo bimestre. No terceiro bimestre nós temos o projeto mais amplo de todos, que nós chamamos a Festa de São Mauro, com a Noite de Gala São Mauro, em que, ao mesmo tempo, há uma exposição de Artes Plásticas, e uma grande festa de Teatro, mas que, como você sabe, envolve muito Línguas, porque pelo menos duas peças... nós temos sempre uma peça representada em francês e uma peça representada em inglês, além de tudo que envolve arte, na confecção das máscaras, na confecção de todo o cenário. Como você sabe é um projeto muito amplo, que envolve muitas habilidades... 
- Música...

- Muita música, é muito amplo, esse projeto, que se desenvolve em outubro. E depois nós temos, no final do ano, a SMart, que é a São Mauro Arte, uma grande feira de Artes Plásticas. Então essas feiras são exatamente a ocasião dos professores poderem preparar esses projetos interdisciplinares. É também, do ponto de vista da integração do colégio no grupo de pais, no grupo do bairro, é a ocasião do colégio mostrar o trabalho de seus alunos. Então, toda essa questão, o fato de que vêm os pais, de que vêm outras pessoas, tudo isso gera um interesse muito grande nos alunos. Então são ocasiões de aprendizado muito privilegiadas, e por isso muito importantes para o nosso projeto global.

- O que você achou desse projeto especificamente, o Histoire de la technologie maritime, você participou como visitante da Feira, assistiu à exposição dos alunos, então qual é a sua opinião sobre esse projeto exatamente?

- Eu, além de ter participado como visitante da Feira, eu participei também como visitante da sala multimídia, quando os projetos estavam sendo preparados. Além disso, como você sabe, o aprendizado de Francês é uma coisa que me interessa particularmente, eu mesma estudei Francês, eu entrei na USP para fazer uma graduação de Francês e assim, desde o começo, desde que eu montei o projeto do colégio, eu sempre quis que, além do Inglês, eles tivessem o Francês. Então esses projetos que envolvem o Francês me interessam muito. Enquanto eu estive na sala multimídia, eles estavam preparando os projetos, fazendo a pesquisa, pesquisando ilustrações, eu fiquei contente porque eu achei que eles demonstravam um grande interesse. E o que eu acho que talvez seja o melhor, principalmente os rapazes, com quem eu conversei, era um projeto que estava mais focado naquilo que eles estavam aprendendo, no que propriamente no Francês. Para eles aquilo não era um trabalho de Francês. Eles estavam aprendendo sobre propulsão, os modos de propulsão dos barcos, os tipos de energia, e eles estavam muito interessados nisso, de modo que o francês entrava com uma facilidade muito grande. O Francês era um instrumento que estava servindo muito bem para o que eles queriam 
e para o que eles precisavam. E isso me pareceu muito bom: porque normalmente quando a gente está estudando língua, a gente presta atenção na língua que a gente está aprendendo, e ali não era isso, eles estavam prestando atenção naquilo que eles estavam aprendendo, nesse conteúdo sobre os barcos, sobre os ventos, e tudo isso, e aí o Francês, de repente o Francês era fácil, e era interessante e era um instrumento muito bom para eles. Isso foi o que eu vi quando eu fui visitar o projeto em execução na sala multimídia. E depois o resultado que eu assisti, lá no teatro, fui lá ver as apresentações que eles tinham na tela, na tela de multimídia, correspondeu a isso. Os trabalhos estavam interessantes, eles estavam interessados em explicar o trabalho. Bom eles em geral sabem que eu leio francês, mas tem um menino que é o primeiro ano dele no Colégio, então ele estava preocupado em me traduzir o francês. O trabalho... me pareceu um trabalho muito bom e o que mais me chamou a atenção foi essa questão: do Francês transformado num instrumento útil para eles. Eles estarem aprendendo língua sem aquele foco na língua. Aí a língua ficava uma coisa extremamente interessante. Porque eliminava aquela clássica pergunta dos estudantes, que é muito freqüente nos estudantes que têm preguiça mas um pouco é a pergunta de todo estudante, que é: "Para que, eu estou aprendendo isso?" Ali não tinha "Para que eu estou aprendendo Francês?" O Francês era um instrumento muito importante para eles.

- Bom, uma última pergunta. Como você vê a perspectiva do ensino com multimídia, em relação ao Colégio, ao Ensino Médio, ao Brasil, enfim do ensino com multimídia?

- Eu acredito que a multimídia é um meio muito bom e que apresenta muitos perigos. Porque a multimídia é um instrumento. Não adianta... Eu ouço falar do projeto do Governo de pôr computadores em todas as salas de aula, de pôr Internet em todas as escolas... Nada disso vai adiantar coisa nenhuma se não houver profissionais capacitados, que saibam muito bem como? e para que? eles vão utilizar isso. A multimídia é um risco na medida em que se se pensa que um estudante vai aprender mais por ser deixado em frente de um computador, está-se completamente enganado. Provavelmente, se não houver uma orientação, uma supervisão, 
profissionais aplicando projetos adequados, direcionando o trabalho, supervisionando o trabalho, o que vai acontecer é que cada um vai entrar no seu Orkut, e eles vão ficar batendo papo. E vão perder um tempo que eles, não tendo o computador, dedicariam ao estudo. Então...

\section{- Era melhor que eles jogassem futebol.}

- Era melhor que eles jogassem futebol. Pelo menos desenvolvia mais fisicamente e mesmo outras habilidades eles desenvolveriam mais. Então a multimídia, a Internet na escola, os computadores são um excelente instrumento. Agora, nenhum instrumento vale nada se ele não está nas mãos de quem sabe utilizá-lo. Então, bem utilizado, como foi o caso desse seu projeto e os de outros professores, por exemplo, o nosso professor de Física usa muito um projeto de Astronomia. Mesmo para Artes, para o conhecimento de todo um acervo cultural a que o acesso é difícil para os alunos - poucos podem ir para a Europa, conhecer os grandes museus e para uma série de trabalhos, a multimídia ela é, digamos, uma biblioteca fantástica. Tem-se acesso a tudo. Mas, como todo instrumento, quanto mais preciso, quanto mais elevado, sofisticado, é um instrumento, mais precisa de um profissional preparado para usá-lo bem. Quero dizer, qualquer um usa uma faca de cozinha, um bisturi precisa de um cirurgião muito bem preparado. A multimídia é pouco assim: um instrumento muito sofisticado que, se não for muito bem usado, pode ser um risco, no contexto do desmantelamento absoluto da educação brasileira.

- Ta certo, então muito obrigada.

- Não há de que. 


\section{Anexo 5 - Entrevista com a professora de História}

Transcrição da entrevista, gravada em 14.05.08, com a professora de História Laura Pinca da Palma, "parceira" no projeto interdisciplinar Histoire de la technologie maritime.

- Então, professora, na sua opinião, qual foi o resultado geral do trabalho ? como foi a nossa colaboração ? Em que sentido ela pode ser estendida a outras vezes? Quais são as vantagens desse tipo de trabalho?

- É um tipo de trabalho bastante interessante, ao qual deveria ser dada continuidade, que deveria continuar a ser desenvolvido no Colégio porque como História tem um determinado conteúdo a ser tratado é sempre bom que a gente possa ter a colaboração de outras matérias que não têm talvez uma exigência tão grande de conteúdos, como é o Francês, mas é uma ferramenta, um meio de aprender e que a gente possa preencher essas matérias com os conteúdos que a gente precisa...

- [risos] Isso é muito interessante, eu entro com o instrumento e História entra com o conteúdo, é uma idéia muito interessante...

- É, mas porque...

- Sim, porque de todo jeito eu vou dar conteúdos que não são de língua, específicos...

- Então, isso é uma coisa que eu defendo até que se estenda a outras matérias, como Computação, e isso porque? Porque assim as crianças podem trabalhar com o conteúdo que eles estão vendo em História, no caso, ou em Geografia, de maneira mais intensa. Fora que assim... sem dúvida, o Francês é uma ferramenta muito importante para o estudo de História, porque a maioria, com exceção de História do Brasil, a maior parte da História Geral está na língua francesa, tanto no livros, quanto na Internet, né? Os sites mais importantes, os estudos mais importantes estão, normalmente, em francês, até mais do que em inglês, então para eles é...

- Então é um campo em que o Francês predomina?

- Isso, sem dúvida. Então o fato de eles trabalharem com o Francês, para História, é bem importante. Assim, mesmo em comparação com a História Americana, porque os americanos são muito autocentrados, já os franceses eles têm [uma visão mais ampla]... mas mesmo que eles sejam auto-centrados 
também, a História da França e da Europa, em geral, se refletiu muito na História do Mundo, em termos gerais, né? Então, acho que é isso. E todo o processo, o trabalho interdisciplinar é importante para o desenvolvimento deles, porque eles acabam gostando mais. Eu percebo isso, eles acabam gostando mais porque tem mais relações, é uma coisa mais ampla, né?

- Está certo. No caso da Feira de História, qual seria a vantagem de trabalhar com o Francês nessa questão da Feira, quer dizer, a Feira é uma coisa feita para expor o trabalho para a comunidade. O fato de eles trabalharem, ao mesmo tempo, com duas matérias, no caso da Feira, isso é vantajoso?

- É vantajoso para o próprio desenvolvimento deles, porque dominando o francês eles aprendem mais História e, ao mesmo tempo, aprendem francês. Já que eles têm que aprender o conteúdo de História, pesquisando em francês, isso dá uma possibilidade de eles já melhorarem o francês deles, e é interessante para os pais, que possam ver o trabalho que eles estão desenvolvendo relacionando todas as matérias que há no Colégio, utilizando, já no colégio, o francês como instrumento de pesquisas.

- Interessante. E outra coisa que eu queria saber, nesse trabalho específico, você chegou a ver o que eles estavam fazendo, ou não?

- Sim. Eu vi.

- E o que achou? O nível estava dentro do esperado para o Primeiro Médio, ou estava fraco?

- Não, acho que estava dentro do esperado. Assim, eu mandei eles também fazerem uma pesquisa, anterior ao trabalho, em português, e ela foi compatível com a pesquisa em francês e, em alguns trechos, ela foi superior em francês. Exatamente por isso, em termos de desenvolvimento das navegações, em língua portuguesa, a gente tem um material pequeno, né, enquanto que eu francês a gente tem um material muito mais rico.

- Embora fossem os portugueses os “reis da matéria”...

- Embora fossem os portugueses os reis da matéria, justamente por isso. Quando a História das Navegações se pesquisa em português, primeiro que não se acha - eu pedi diversas vezes para eles pesquisarem “História das navegações”, ” desenvolvimento das navegações” e só sai o desenvolvimento das navegações portuguesas e o interesse do estudo era que se visse as navegações desde o começo, 
desde o Egito antigo até a Idade Moderna e, em língua portuguesa, particularmente, só se encontravam navegações portuguesas. Então até eu pedi, né, que eles buscassem em outras línguas, porque em português era quase redundante só achar navegações portuguesas. E os textos em francês eram mais completos, porque não estão focados nas navegações portuguesas, justamente tratavam do desenvolvimento das navegações em termos gerais. Então acho que foi bem importante para eles pesquisarem com o francês, só com o português eles não conseguiriam desenvolver os cartazes, desenvolver as explicações como eles desenvolveram. Os sites em português não eram suficientes para eles fazerem isso.

- Está certo. Então ta bom, muito obrigada. Agradeço muito. 


\section{Anexo 6 - Entrevista com o professor de Informática}

Esta entrevista foi realizada por e-mail em 02.11.08.

- Professor Fabiano Armellini, eu gostaria de saber sua opinião sobre alguns aspectos de seu trabalho como professor de Informática.. Qual é a necessidade de uma disciplina específica de Informática no ensino fundamental e médio? Dentro dessa disciplina, o que é mais importante ensinar?

- Em nossos dias o computador assume uma posição de grande importância em nossa sociedade. A informática está presente no dia-a-dia das pessoas, e assume também um papel fundamental nas relações de trabalho. Ter, portanto, domínio das ferramentas computacionais é um diferencial que se torna a cada dia mais crucial para o bom desempenho. Mesmo no meio escolar o uso do computador transformou algumas das práticas de ensino com relação à forma em que outrora era de praxe. Por exemplo, o uso da Internet como fonte de pesquisa bibliográfica já se tornou uma prática que tornou obsoleta a consulta a enciclopédias em forma de livro, como a Barsa.

Por conta de todas essas transformações nos âmbitos pessoal, profissional e educacional que o computador gerou em nossa sociedade, daí decorre a importância de uma disciplina específica de Informática no ensino fundamental e médio.

Um outro aspecto da disseminação da informática e principalmente da Internet entre nossos jovens é que se por um lado ela traz uma série de benefícios e facilidades para o homem moderno, por outro é um ambiente prenhe de perigos e riscos. Muitos crimes hoje são veiculados por meio da Internet, como fraudes, invasão a sistemas bancários para roubo de dinheiro entre outros crimes. É de fundamental importância, portanto, saber se proteger contra os chamados hackers e outros "criminosos digitais" e as ferramentas esses usam, como os vírus, cavalos-de-tróia entre outros.

Além disso, pela internet ser um ambiente propício para construção de redes de relacionamento, ela também é muito usada para a prática de outros crimes sociais, como prostituição, pedofilia, corrupção de menores. É também sabido que mais da metade do conteúdo disponível na internet é pornográfico.

Por conta de tudo isso parece um tanto óbvio que abandonar nossos jovens à própria sorte na internet é colocá-los em posição de grande perigo para suas vidas e para suas almas. Daí a necessidade de instrução por parte dos pais principalmente, mas também das escolas.

Com base no que já disse, dentro dessa disciplina acredito que os tópicos que a escola deve se 
propor a ensinar aos seus alunos são:

1) Noções básicas de informática (o que é um computador, suas partes, sistemas operacionais, operações básicas)

2) Noções de internet (o que é, como funciona, suas vantagens, seus perigos)

3) Algumas ferramentas básicas que são hoje amplamente usadas do dia-a-dia pessoal e profissional, como ferramentas de texto (Word), planilhas de dados (Excel), bancos de dados (Access), apresentações (Powerpoint)

4) Noções de programação e algoritmos, que são a base das Ciências da Computação

- Qual é a utilidade do recurso à informática e também, mais especificamente, à Internet, nesses níveis de ensino?

- Como já disse, a Internet permeia hoje grande parte das nossas atividades do dia-a-dia. Tornou-se um "vício" dos nossos dias recorrermos à internet como fonte de informações, e é a primeira fonte consultada pela maioria das pessoas que adotam essa ferramenta. Dado que a atividade escolar exige, em suas várias disciplinas, muita pesquisa, esse é, a meu ver, a principal utilidade da Internet para o aluno de ensino fundamental e médio.

Quanto aos demais recursos de informática, é notório que ferramentas de texto, apresentação e planilhas de dados podem prestar grande auxílio no desenvolvimento de trabalhos escolares. Eu pessoalmente, porém, não apóio o seu uso intensivo no ensino fundamental e médio, especialmente o uso de ferramentas de texto para redação. O motivo para isso é bastante simples: as facilidades que essas ferramentas na redação de um texto, permitindo a inserção de um novo texto no meio de um texto já escrito, o uso do "backspace" e do "delete" para se reescrever um texto, e o fato dessas ferramentas possuírem corretores gramaticais e ortográficos, essas facilidades não contribuem para as duas principais funções de um curso de Redação, que são ensinar os alunos a estruturarem um raciocínio, e a escreverem bem e corretamente. $\mathrm{O}$ aluno precisa aprender a escrever independentemente da disponibilidade dessas facilidades. Por isso sou contra o seu uso exclusivo no ensino fundamental e médio.

- O que pensa de projetos interdisplinares envolvendo Internet, como os que temos feito aqui no colégio? Em que condições eles podem funcionar?

- Nas aulas de informática, por tratarmos de ferramentas operacionais, o método mais efetivo de aprendizado é o de "aprender fazendo". Para o professor de informática, os projetos interdisciplinares 
são muito importantes para enriquecer o conteúdo das aulas. As ferramentas básicas que citei anteriormente (Word, Excel e Powerpoint) foram projetadas para resolver problemas específicos, e seu uso muitas vezes é intuitivo: é o que chamamos de interfaces "user-friendly", isso é, interfaces amigáveis para o usuário. A grande dificuldade do professor de informática é gerar no ambiente de aula as dificuldades que levaram os desenvolvedores de software a projetar uma ferramenta específica para resolvê-los. O grande risco é o aluno achar que está fazendo uma atividade tola, que não serve para nada, só porque o professor pediu. Se, por outro lado, os professores de outras disciplinas sugerem trabalhos que demandam o uso do computador, a própria demanda cria a dificuldade, e o aluno tem facilidade em compreender a utilidade da ferramenta.

O funcionamento dessa forma interdisciplinar de trabalho só funciona, no entanto, se bem organizada previamente entre os professores de informática de da(s) disciplina(s) do objeto do trabalho, e se o aluno for orientado e avaliado, sob ambos os aspectos, por todos os professores envolvidos no projeto.

- Quais seriam suas sugestões a esse respeito?

- A minha sugestão aqui é a de ser montada a grade de aulas de informática de forma integrada com o ensino das outras disciplinas do colégio, de forma que o aluno esteja nessas aulas, na maior parte do tempo, realizando trabalhos de outras disciplinas, onde ele também estaria aprendendo a utilizar essas ferramentas computacionais.

- Obrigada,

- Ao dispor! 


\section{Anexo 7 - Documento Leitura e Linguas Estrangeiras no Projeto}

\section{Pedagógico do Colégio}

Leitura e Línguas Estrangeiras no Projeto Pedagógico do Colégio

O Projeto Pedagógico do Colégio São Mauro considera a formação escolar básica como um processo de aquisição de ferramentas que permitiam ao educando um aprendizado continuado. Concordamos inteiramente com a afirmação do Prof. Simon Schwartzman, especialista em educação, tecnologia e pesquisa científica, Ph.D. pela Universidade da Califórnia, professor da Universidade São Paulo e dirigente de pesquisas da Fundação Getúlio Vargas, segundo o qual, hoje é necessário "concentrar o esforço dos alunos na aquisição de habilidades fundamentais, que são as que efetivamente contam. A formação genérica, inclusive nas humanidades, habilita a aprender para o resto da vida. Isso é decisivo, já que não adianta mais dar formação técnica muito especializada a um operário para lidar com uma máquina. O provável é que, ao longo de sua vida produtiva, a máquina fique obsoleta - e ele também. Operário especializado é, daqui para a frente, o que pode ler um manual, muitas vezes em inglês, e entender o software de controles computadorizados. Ou seja, que tenha pelo menos a escola secundária bem feita." (VEJA, 13.07.1994). Nessa perspectiva, a aquisição competente, tanto da língua materna quanto de duas línguas estrangeiras modernas é fundamental. $\mathrm{O}$ domínio dessas línguas abre o campo de possibilidades de aquisição de conhecimentos. Além do mais, do ponto de vista de formação humana, de contato do aluno com o patrimônio artístico e cultural da humanidade, que valorizamos muito, um bom conhecimento do português, do inglês e do francês também são essenciais.

É claro que nesse contexto, a leitura deve ser extremamente valorizada. Assim, desde o primeiro ano do ensino fundamental ( 6 anos) os alunos passam a ter leituras de livros obrigatórias. Um livro por semestre no primeiro ano, um por bimestre do segundo ao quinto ano, dois por bimestre a partir do 6․ Ano até o $3^{\circ}$. Médio. Fazemos ainda, a partir do 6․ Ano, os Relatórios de Leitura, em que os alunos escolhem livros que queiram ler, que são aprovados pelo professor, e fazem sobre eles exposições orais. Todo o primeiro ciclo do Ensino Fundamental tem também um programa cerrado de leitura e interpretação de pequenos textos. Além disso, inspirados na escola francesa, em que é tradicional "la petite page de lecture du soir", vamos implantar já no segundo semestre de 2008, a partir do nível Beta (4 anos) um programa de leituras curtas que devem ser feitas pelos pais, de início, mas cada vez mais pela criança, na hora de dormir. Nosso objetivo, como é claro, é desenvolver ao máximo a funcionalidade da leitura. 


\section{Une partie de la Chine bloquée par le froid}

\section{1-02-2008}

Le Centre, I'Est et le Sud de la Chine sont confrontés à une vague de froid, dont l'ampleur et la durée sont sans précédent depuis plus de cinquante ans. Selon les agences de presse chinoises, ce sont plus de cent millions d'habitants, répartis dans une douzaine de provinces, qui seraient touchés par les intempéries, essentiellement des fortes averses de neiges et des pluies verglaçantes.

Depuis plusieurs jours, dans certaines régions, les moyens de communication, routes, aéroports et voies ferrées sont totalement paralysés. Cette situation s'avère particulièrement catastrophique car elle coïncide avec la grande migration annuelle de la population, liée à la fête du nouvel an chinois du 7 février. Ainsi ce sont plusieurs centaines de milliers de voyageurs qui se sont retrouvés bloqués dans les gares et sur les routes; rien que pour la gare de Canton, le nombre de personnes en attente de trains est estimé à 300000 . Sur certaines portions de routes et d'autoroutes du pays ce sont des dizaines de milliers de personnes qui sont prises au piège de la glace et des chutes de neige.

Au niveau énergétique, la situation est tout aussi catastrophique et empire de jour en jour. Beaucoup de lignes de transport électrique ont été coupées, générant de nombreuses et longues coupures de courant. Dans l'ensemble des régions en proie aux intempéries, la production et le transport du charbon sont paralysés. Or, le charbon assure plus de $70 \%$ de la production électrique du pays et la pénurie gagne de plus en plus de centrales thermiques, dont certaines, encore en fonction, estiment avoir des réserves de combustibles pour moins d'une semaine de production.

\section{Michel Sage}

Répondez aux questions ci-dessous, compte tenu des textes

1. Quel genre d'intempéries a touché la Chine au mois de janvier?

2. Combien de personnes sont-elles touchés par la vague de froid?

3. Avec quelle festivité chinoise a-t-elle coïncidé ?

4. Comment la vague de froid a-t-elle ateint les festivités?

5. Quelles en sont les conséquences pour les lignes éléctriques? 
6. En quoi la pénurie de charbon peut-elle être catastrophiques?

\section{1-02-2008 Intempéries : lourd bilan pour les forêts chinoises}

La vague de froid qui a touché la Chine au mois de janvier a eu des conséquences catastrophiques sur les forêts chinoises. D'après les services de l'Administration d'Etat des Forêts, ce sont plus de 17 millions d'hectares boisés qui ont été endommagés par les fortes chutes de neige et le gel ; rapporté au niveau du pays cela représente environ $10 \%$ de la surface forestière totale chinoise. Dans certaines régions, les dégâts sont considérables et des forêts ont été détruites à près de $90 \%$.

Un vaste plan de nettoyage des arbres affectés par les intempéries devrait être conduit à partir du mois d'avril. Cao Qingyao, porte-parole de l'Administration d'Etat des Forêts, a estimé urgent d'enlever les arbres morts afin d'éviter des incendies « catastrophiques » lors du prochain été.

Les autorités chinoises craignent aussi que certains profitent de la « pagaille » pour abattre sans discernement des arbres et aggravent ainsi les pertes.

Lors des 26 dernières années, le gouvernement chinois a mis fortement à contribution sa population pour mener un vaste programme de plantation d'arbres. D'après le Quotidien du Peuple, ce sont au total plus de 49 milliards d'arbres qui ont été plantés dans le cadre du programme de « plantation obligatoire » soit 21,9 millions d'hectares de forêt.

\section{Michel Sage}

7. Qu'a produit aux forêts la vague de froid qui a touché la Chine?

8. Combien répresente le total de forêts endommagés par rapport à l'ensemble des forêts chinoises ?

9. Qu'est-ce qu'il faudra faire dans les régions affectés, selon le gouvernement chinois ?

10.Que signifie l'expression « a mis fortement à contribution » dans le texte ?(en portugais) 


\section{LE MONT-SAINT-MICHEL}

Thème : Monuments

SITES : www.asteria.fr ; www.mont-saint-michel.com ; www.monum.fr

Objectifs :

Compréhension écrite sélective

Grammaire : poser des questions ; se situer dans le temps

\section{VISITE EN BRETAGNE}

Avant de " visiter » le Mont-Saint-Michel, faisons un rapide petit tour en Bretagne qui peut justifier au moins 15 visites... Allez sur le site www.asteria.fr et faites correspondre les villes avec leurs caractéristiques qui apparaissent lorsqu'on passe la flèche (le curseur) de la souris sur le nom de la ville.

\begin{tabular}{|c|c|c|c|c|}
\hline & & Ville & & Caractéristique \\
\hline 1. & $\mathrm{~F}$ & Pont-Aven & A & Un château. Une histoire qui remonte à l'an 1000. \\
\hline 2. & & Le cap Fréhel & B & Des plages idéales. \\
\hline 3. & & Dol-de- Bretagne & C & Le joli village dont parle Chateaubriand. \\
\hline 4. & & Fougères & D & La cité des plus grands coureurs d'aventure. \\
\hline 5. & & Rochefort-en-terre & E & Au cœur de la Haute-Bretagne. \\
\hline 6. & & Erquy & F & La renaissance de la peinture contemporaine. \\
\hline 7. & & Plancoët & G & Un port de pêche breton typique. \\
\hline 8. & & Saint-Malo & H & Terre d'accueil, riche patrimoine culturel. \\
\hline 9. & & Dinan & 1 & Un éperon rocheux, un site pittoresque. \\
\hline 10. & & Cancale & J & 24 kilomètres de côtes, des falaises de grès, des plages. \\
\hline 11. & & Bazouges & K & Un point de départ pour visiter la Bretagne romantique. \\
\hline 12. & & Jugon-les-lacs & $L$ & $\begin{array}{l}\text { Une ville d'art au riche patrimoine architectural, naturel, } \\
\text { historique. }\end{array}$ \\
\hline 13. & & Combourg & M & Une station verte de vacances. \\
\hline 14. & & Auray & $\mathbf{N}$ & Un des hauts lieux de la spiritualité occidentale. \\
\hline 15. & & Le Mont-Saint-Michel & 0 & Un village d'artistes au sommet d'une colline. \\
\hline
\end{tabular}




\section{Questionário Leitura em Internet e aprendizagem de FLE}

\begin{tabular}{|c|}
\hline Data: ___ Nome: $\ldots$ Idade: \\
\hline Acesso à Internet \\
\hline $\begin{array}{l}\text { 1. Você tem acesso à Internet? } \\
\text { a) em casa b)na escola c) Lan House }\end{array}$ \\
\hline 2. Há quanto tempo? (anos e meses)_ \\
\hline $\begin{array}{l}\text { 3. Quanto tempo você usa o computador? } \\
\begin{array}{ll}\text { a) por dia? } & \text { b) por semana? }\end{array}\end{array}$ \\
\hline $\begin{array}{l}\text { 4. Você "baixa" textos da Internet para ler posteriormente? } \\
\text { a) sim b) não }\end{array}$ \\
\hline $\begin{array}{l}\frac{\text { Leitura }}{5 . \text { Você gosta de ler? }} \\
\text { a) sim b) não }\end{array}$ \\
\hline $\begin{array}{l}\text { 6. O que leva você a ler? (assinale quantos quiser) } \\
\text { a) prazer b) estudo c) obrigação d)não leio }\end{array}$ \\
\hline $\begin{array}{l}\text { 7. Que tipo de publicação você lê? } \\
\text { a) livros b) revistas c) jornais d) apostilas e) gibis f) outros g) só Internet }\end{array}$ \\
\hline
\end{tabular}

Leitura em Tela

8. O que você acha de ler na tela? (assinale quantos quiser)
a) igual ao papel
b) mais difícil
c) mais cansativo
d) mais fácil
e) mais rápido
f)mais agradável

9. Você imprime textos para ler em papel?

a) $\operatorname{sim}$ b) não c) às vezes

10. Quanto tempo você lê na tela?
a) o máximo que eu já li direto
c) com intervalos
b) o tempo médio que eu leio no total

Leitura em Internet

11. Que tipo de texto você lê mais? (calcule uma porcentagem) 


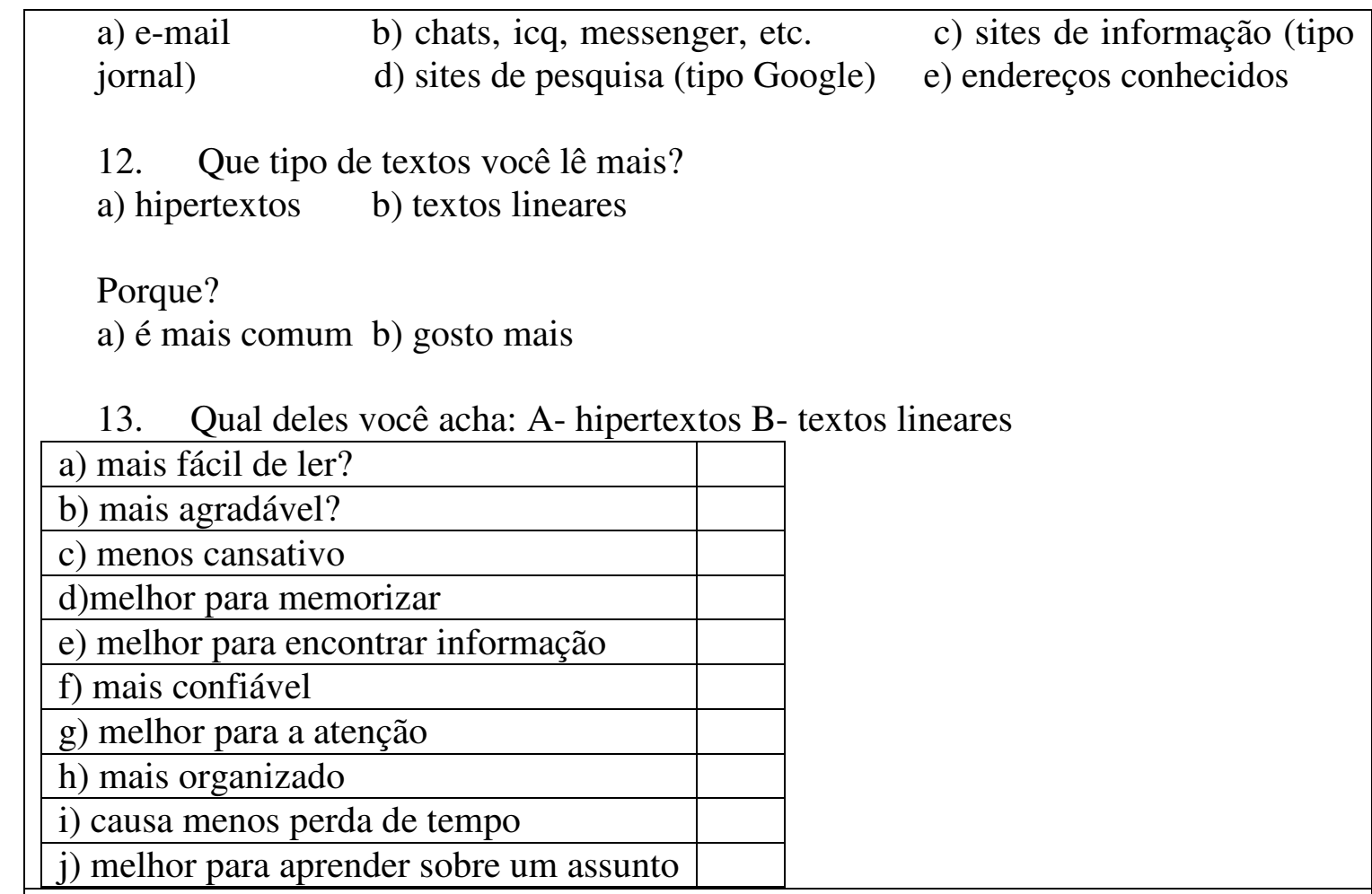

$\underline{\text { Leitura em Internet }}$

11. Que tipo de texto você lê mais? (calcule uma porcentagem)
a) e-mail
b) chats, icq, messenger, etc.
c) sites de informação (tipo jornal)
d) sites de pesquisa (tipo Google)
e) endereços conhecidos

12. Que tipo de textos você lê mais?
a) hipertextos
b) textos lineares

Porque?

a) é mais comum b) gosto mais

13. Qual deles você acha: A- hipertextos B- textos lineares

\begin{tabular}{|l|l|}
\hline a) mais fácil de ler? & \\
\hline b) mais agradável? & \\
\hline c) menos cansativo & \\
\hline d)melhor para memorizar & \\
\hline e) melhor para encontrar informação & \\
\hline f) mais confiável & \\
\hline g) melhor para a atenção & \\
\hline h) mais organizado & \\
\hline i) causa menos perda de tempo & \\
\hline j) melhor para aprender sobre um assunto & \\
\hline
\end{tabular}

Internet e FLE

14. Quando pesquisa um assunto, você procura sites em língua estrangeira?
a) $\operatorname{sim}$
b)não

Quais línguas?
a) espanhol
b) francês
c) inglês 


\section{Anexo 11 - Tabulação do Questionário Leitura em Internet e aprendizagem de FLE}

\begin{tabular}{|c|c|c|c|c|}
\hline Nom & José Akira & Mariana Garcia & & \\
\hline e & Mori Xavier & Nakamura & Grabiela Parra & Angel Souza Liu \\
\hline Série & 1 & 1 & 1 & 1 \\
\hline idade & 16 & 14 & 15 & 15 \\
\hline 1 & casa & casa & casa & casa \\
\hline 2 & 4 anos & 7 anos & 8 anos & 6 anos \\
\hline 3-a & $\mathrm{n} / \mathrm{c}$ & $1 \mathrm{~h}$ & $1 \mathrm{~h}$ & $3 \mathrm{~h}$ \\
\hline $3-b$ & $\mathrm{n} / \mathrm{c}$ & $5 \mathrm{~h}$ & $5 \mathrm{~h}$ & $5 \mathrm{~h}$ \\
\hline $3-c$ & $1 \mathrm{~h}$ & $20 \mathrm{~h}$ & $15 \mathrm{~h}$ & $20 \mathrm{~h}$ \\
\hline 4 & $\operatorname{sim}$ & não & $\operatorname{sim}$ & $\operatorname{sim}$ \\
\hline 5 & não & mais ou menos & $\operatorname{sim}$ & $\operatorname{sim}$ \\
\hline 6 & $\begin{array}{l}\text { prazer/ } \\
\text { estudo/ } \\
\text { obrigação }\end{array}$ & $\begin{array}{l}\text { estudo/ } \\
\text { obrigação }\end{array}$ & prazer/ estudo & prazer/ estudo \\
\hline 7 & $\begin{array}{l}\text { revistas/ } \\
\text { jornais/ } \\
\text { apostilas/ } \\
\text { outros }\end{array}$ & $\begin{array}{l}\text { livros/ revistas/ } \\
\text { apostilas }\end{array}$ & $\begin{array}{l}\text { livros/ revistas/ } \\
\text { jornais }\end{array}$ & livros/ apostilas/ outros/ internet \\
\hline
\end{tabular}

\begin{tabular}{|c|c|c|c|c|}
\hline & mais & & & \\
\hline 8 & cansativo & mais cansativo & mais cansativo & mais cansativo \\
\hline 9 & não & às vezes & às vezes & $\operatorname{sim}$ \\
\hline 10-a & $3 \mathrm{~h}$ & $2 \mathrm{~h}$ & $20 \min$ & $30 \mathrm{~min}$ \\
\hline $10-b$ & $1,5 \mathrm{~h}$ & $1 \mathrm{~h}$ & $5 \mathrm{~min}$ & $2 \min$ \\
\hline 10-c & $5 \mathrm{~h}$ & $3 \mathrm{~h}$ & $2 \mathrm{~h}$ & $10 \mathrm{~min}$ \\
\hline 11 & $\begin{array}{l}\text { e-mail/ } \\
\text { pesquisa/ }\end{array}$ & e-mail/ chats etc & e-mail/ & o-mail/chatc otc \\
\hline $12-a$ & $\begin{array}{l}\text { textos } \\
\text { lineares }\end{array}$ & textos lineares & textos lineares & textos lineares \\
\hline $12-b$ & $\begin{array}{l}\text { gosto mais } \\
\text { textos }\end{array}$ & gosto mais & gosto mais & gosto mais \\
\hline $13-a$ & $\begin{array}{l}\text { lineares } \\
\text { textos }\end{array}$ & textos lineares & textos lineares & textos lineares \\
\hline $13-b$ & $\begin{array}{l}\text { lineares } \\
\text { textos }\end{array}$ & textos lineares & textos lineares & textos lineares \\
\hline 13-c & $\begin{array}{l}\text { lineares } \\
\text { textos }\end{array}$ & textos lineares & textos lineares & textos lineares \\
\hline 13-d & lineares & textos lineares & textos lineares & textos lineares \\
\hline
\end{tabular}




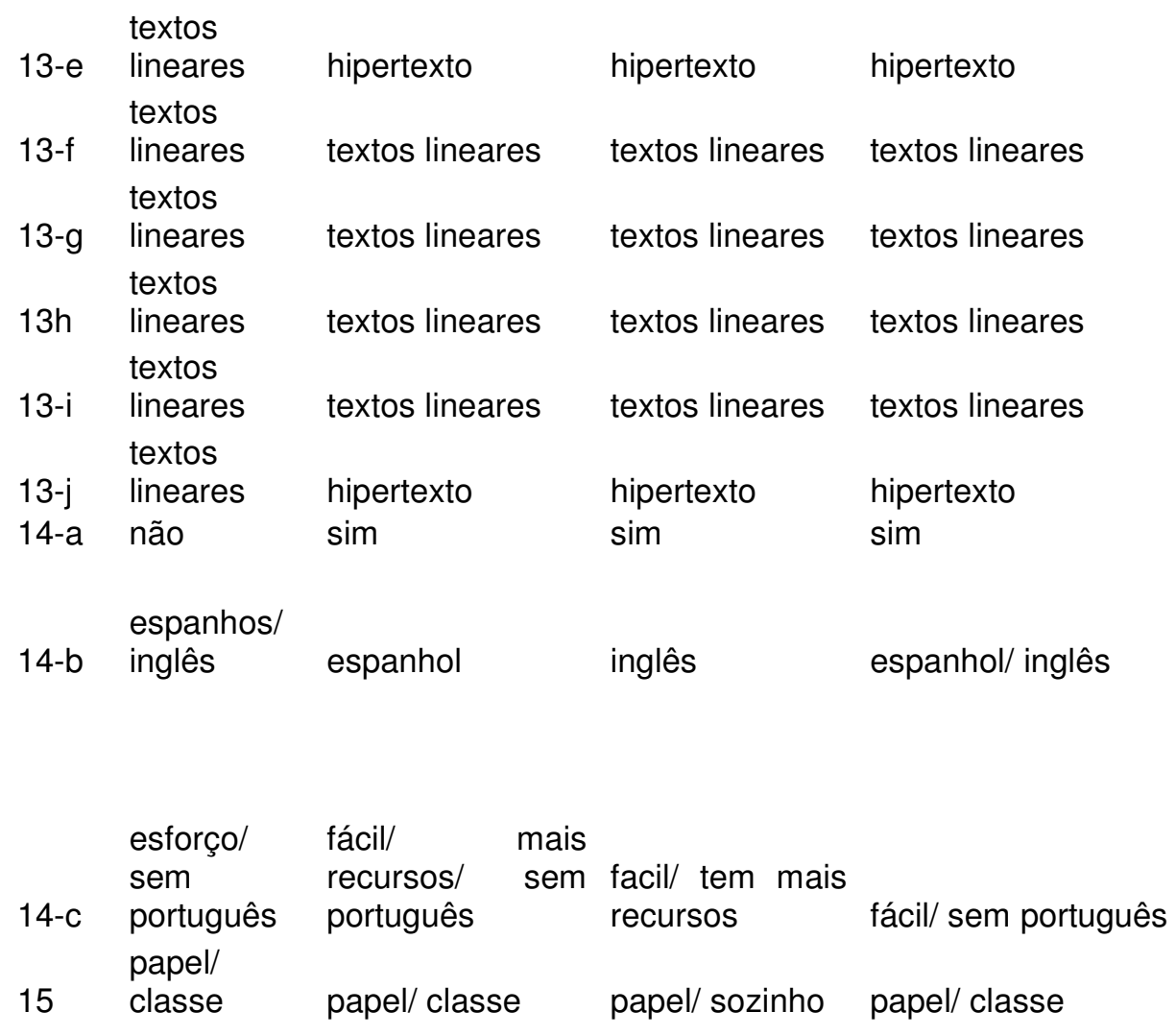

procuro em

português procuro em

e depois português e

coloco no depois coloco no Procuro em site

tradutor tradutor de busca na

16 automatico automatico propria lingua Procuro em site de busca na propria lingua

vendo um

amigo

fazer.

Aprender

da melhor Sozinha, em

17

maneira sozinha

casa

Sozinha, Aprender a pesquisar mais rapidamente 
Anexo 12 - Questionário de Avaliação do Projeto Histoire De la Technologie maritime, exemplar preenchido por Karysa

\section{Trvaliação do Projeto}

Nome: Karysa Fernandes dos Santos Data: 29/04/2008

1. Como você avalia sua capacidade de leitura

a. antes do projeto?

()Ótima (X)boa () mediana

fraca

()péssima

b. depois do projeto?

(X)Ótima ()boa () mediana fraca ()péssima

2. Como você avalia sua capacidade de encontrar informações ?

a. antes do projeto?
()Ótima
()boa
() mediana

(X)

fraca

()péssima

b. depois do projeto?
()Ótima
()boa
(X) mediana

fraca

()péssima

3. Diga que você pensa sobre estes aspectos do projeto:

a. interdisciplinaridade 
Interessante, mas dependenda do texto um pouco complicado

\section{b. trabalho de projetos}

Oivertido, pois desenvolve a nossa capacidade intelectual.

\section{c. leituras em internet}

Yormal, já estou acostumada, mas mesma quando comecei a lex na internet nãa tive problemas.

\section{d. leitura em Francês}

Oepende do teato se é um tercto complicado eu tenha dificuldade, pois tenho mania de traduzix palawra pox palawera e quando nãa sei a que significa alguma palawra, nãa consiga entender a resta do texto. 


\title{
Anexo 13 - Tabulação do Questionário de Avaliação do Projeto Histoire de la Technologie maritime
}

\author{
TABULAÇÃO DOS RESULTADOS DO QUESTIONÁRIO DE AVALIAÇÃO DO \\ PROJETO HISTOIRE DE LA TECHNOLOGIE MARITIME
}

\begin{tabular}{|l|c|c|c|c|}
\hline & \multicolumn{2}{|c|}{ Capacidade de leitura } & \multicolumn{2}{c|}{ Capacidade de pesquisa } \\
\hline & Antes do projeto & Depois & Antes do projeto & Depois \\
\hline Akira & mediana & boa & ótima & ótima \\
\hline Danillo & fraca & mediana & ótima & ótima \\
\hline Mariana & fraca & mediana & mediana & boa \\
\hline Angel & fraca & mediana & fraca & mediana \\
\hline Caroline & mediana & boa & fraca & mediana \\
\hline Karysa & boa & ótima & fraca & mediana \\
\hline Gabriela & boa & boa & mediana & mediana \\
\hline Inês & mediana & boa & mediana & boa \\
\hline Stella & fraca & mediana & boa & boa \\
\hline Jéssica & fraca & mediana & mediana & mediana \\
\hline
\end{tabular}

\begin{tabular}{|l|l|}
\hline \multicolumn{1}{|c|}{ Opiniões sobre aspectos do projeto } \\
\hline Interdisciplinaridade & $\begin{array}{l}\text { Bastante interessante pois deste modo há um aperfeiçoamento } \\
\text { dos dois idiomas intercalados no momento de estudo.Deste } \\
\text { modo A pessoa (aluno) tem q se esforçar e pode conhecer novo } \\
\text { vocabulário e conhecer seus erros gramaticais em quaisquer } \\
\text { dos idiomas para poder corrigi-lo. (Akira) } \\
\text { Legal, pois nos alem de aprendemos Francês, e também } \\
\text { aprendemos da historia do barco. (Danillo) } \\
\text { Bom, porque faz com que aprendamos sobre duas matérias ao } \\
\text { mesmo tempo. (Mariana) } \\
\text { Interessante mas ao mesmo tempo trabalhoso. (Angel) } \\
\text { Interessante, às vezes um pouco confuso. (Caroline) } \\
\text { Interessante, mas dependendo do texto um pouco complicado. } \\
\text { (Karysa) } \\
\text { Acaba ficando mais fácil, pois você aproveita mais o conteúdo } \\
\text { do trabalho para várias matérias ao mesmo tempo. (Gabriela) } \\
\text { Acho muito interessante, força o aluno a se 'adaptar' ( se } \\
\text { interessar) de um certo modo à língua. (Inês) } \\
\text { Acaba ficando mais fácil,pois você aproveita mais o conteúdo } \\
\text { do trabalho para várias matérias ao mesmo tempo. (Jéssica - } \\
\text { cópia da resposta de Gabriela?) }\end{array}$ \\
\hline Trabalho por projetos \\
$\begin{array}{l}\text { Eu acho que por projeto é melhor, pois o trab por projeto você } \\
\text { tem um limite de entrega inadiável então ele fica mais }\end{array}$ \\
\hline
\end{tabular}




\begin{tabular}{|c|c|}
\hline & $\begin{array}{l}\text { interessante no meu ponto de vista pois vc tem um limite e se } \\
\text { sente obrigado a fazer o trab mas n porque vale nota mas pq vc } \\
\text { sabe q o projeto vai ser visto por outras pessoas e para } \\
\text { satisfazer as pessoas vc deve fazer algo compreensível com } \\
\text { começo meio e fim com uma estrutura básica de um texto } \\
\text { aquele q da sentido.Claro vc tem um compromisso para com os } \\
\text { visitantes q vieram para ver seu trab.Agora o trab sem ser por } \\
\text { projeto no meu ponto de vista não é tão bom pois você mais faz } \\
\text { o trab pela nota q ele vai valer e muitas vezes acaba fazendo } \\
\text { correndo sem muitos detalhes, sem a atenção devida e por } \\
\text { muitas vezes o dia de entrega pode ser adiada deste modo } \\
\text { sendo menos perfeita. (Akira) } \\
\text { Legal,pois nos temos que ter responsabilidades. Foi chato pois } \\
\text { nos tivemos que apresentar para todo mundo. (Danillo) } \\
\text { Interessante. (Mariana) } \\
\text { Foi demorado encontrar o texto de francês na internet, mas no } \\
\text { fim do projeto/o projeto no geral, ficou bom. (Angel) } \\
\text { Divertido mas cansativo. (Caroline) } \\
\text { Divertido, pois desenvolve a nossa capacidade intelectual. } \\
\text { (Karysa) } \\
\text { Gosto, pois aprendo mais sobre o assunto do qual trata o } \\
\text { projeto que será feito. (Gabriela) } \\
\text { É muito melhor do que um simples projeto, pois faz o aluno } \\
\text { comparar em várias fontes um mesmo assunto. O aluno ao } \\
\text { invés de ler apenas um texto, ele precisa pesquisar várias vezes } \\
\text { sobre o mesmo assunto e selecionar somente os mais } \\
\text { interessantes. (Inês) } \\
\text { É muito melhor. (Stella - cópia do início da resposta de Inês) } \\
\text { (Jéssica não respondeu) }\end{array}$ \\
\hline Leitura em Internet & $\begin{array}{l}\text { Nunca gostei muito de ler textos na tela. Após um tempo fico } \\
\text { com dores de cabeça. Não gosto muito mas quando é } \\
\text { necessário acabo sacrificando as dores para fazer o que é } \\
\text { necessário.E como hoje a net é um meio indispensável na } \\
\text { telecomunicação da nossa sociedade ela é o melhor meio de } \\
\text { achar artigos q nos são úteis. (Akira) } \\
\text { Eu sempre li em no computador, e nunca tive dificuldade em } \\
\text { mexer em um. (Danillo) } \\
\text { Ler textos no computador é um pouco cansativo, mas na } \\
\text { internet se tem mais facilidade em achar os textos. (Mariana) } \\
\text { Foi ruim porque eu não gosto de ler texto no computador. } \\
\text { (Angel) } \\
\text { Faço sempre. (Caroline) } \\
\text { Normal, já estou acostumada, mas mesmo quando comecei a } \\
\text { ler na internet não tive problemas. (Karysa) } \\
\text { Não gosto muito, apesar de não me incomodar em ler textos } \\
\text { pequenos. (Gabriela) } \\
\text { É um pouco cansativo. ( O trabalho em internet, apesar de ser } \\
\text { mais prático pois o acesso á vários texto é mais rápido, é pior } \\
\text { pois se perde muito tempo) (Inês) } \\
\text { É um pouco cansativo. (Stella - cópia da resposta de Inês) }\end{array}$ \\
\hline
\end{tabular}




\begin{tabular}{|l|l|}
\hline Leitura em francês & Não é muito agradável. (Jéssica) \\
& Em leitura nunca tive muita dificuldade, depois do trabalho \\
realmente acho q devo ter melhorado um pouco.Eu até tenho \\
facilidade em escutar, entendo conversas não muito específicas \\
ou técnicas.talvez minha maior dificuldade seja falar tenho q \\
pensar muito nas palavras e não consigo falar direito.muitas \\
vezes temo falar bobeira então evito tal linguagem. (Akira) \\
Nunca tive Frances em outro colégio, isso me ajudou a \\
aprender mais palavras. (Danillo) \\
Ler textos em francês faz com que aprendamos com mais \\
facilidade. (Mariana) \\
Um pouco difícil mas é interessante. (Caroline) \\
Depende do texto se é um texto complicado eu tenho \\
dificuldade, pois tenho mania de traduzir palavra por palavra e \\
quando não sei o que significa alguma palavra, não consigo \\
entender o resto do texto. (Karysa) \\
A leitura em francês é muito interessante pois com ela se pode \\
aprender vasto vocabulário de Francês, que pode te ajudar \\
depois a manter um contato normal com franceses quando você \\
viajar ao exterior.Afinal, Francês não é assim tão fácil!!! \\
(Gabriela) \\
Ajuda o aluno a adquirir, sobre tudo, mais vocabulário. Força o \\
aluno a pensar mais sobre a língua, pois para o aluno entender \\
o que está lendo ele precisa usar tudo o que ele sabe da língua. \\
(todo seu conhecimento será aplicado no entendimento do \\
texto) (Inês) \\
Ajuda a aprender francês. (Stella) \\
A leitura em francês é muito interessante porém é uma coisa \\
que eu não consigo fazer. (Jéssica)
\end{tabular}




\section{Anexo 14 - Texto das apresentações em Power Point do projeto Histoire de La Technologie Maritime, comparado com textos de origem na Internet}

A atividade de confecção dessas apresentações, através da seleção de trechos, dentro dos textos encontrados na Internet, teve como primeiro objetivo a avaliação da compreensão de leitura. Entretanto, ficou claro, no decorrer do trabalho, que ela exige também, em larga medida, a capacidade de selecionar os pontos mais importantes de um texto ou de um assunto, além da habilidade de sintetizar esses textos para a extensão aceitável em um slide, habilidades bem mais complexas, que extrapolam o objetivo básico do projeto. Nessa fase do projeto, portanto, as duplas contaram com uma intervenção maior da professora. Tal intervenção ocorria, normalmente, por chamado das duplas durante a leitura, ou na fase de revisão e foi mais ou menos importante, conforme as duplas. A análise do texto resultante revela algo desse trabalho, e deve ser entendida, portanto, sobretudo como uma avaliação da compreensão de leitura. O objetivo dessa comparação foi examinar a extensão do texto que foi lido e a pertinência da escolha dos trechos, lembrando que a escolha desse texto-base implicou na leitura de pelo menos outro texto sobre o mesmo assunto.

Na tabela abaixo, a coluna direita corresponde ao texto selecionado pelos alunos, a partir do texto-base disponível no site consultado, o qual está transcrito na coluna à esquerda. A parte marcada em itálico, no texto-base, corresponde àquela selecionada pelos alunos; na coluna da direita, os caracteres em negrito correspondem a palavras ou frases acrescentadas pelos alunos ao texto inicial. Cada célula da tabela corresponde a um slide, sendo que a extensão do texto escolhido está condicionada ao suportado pelo formato do slide. 


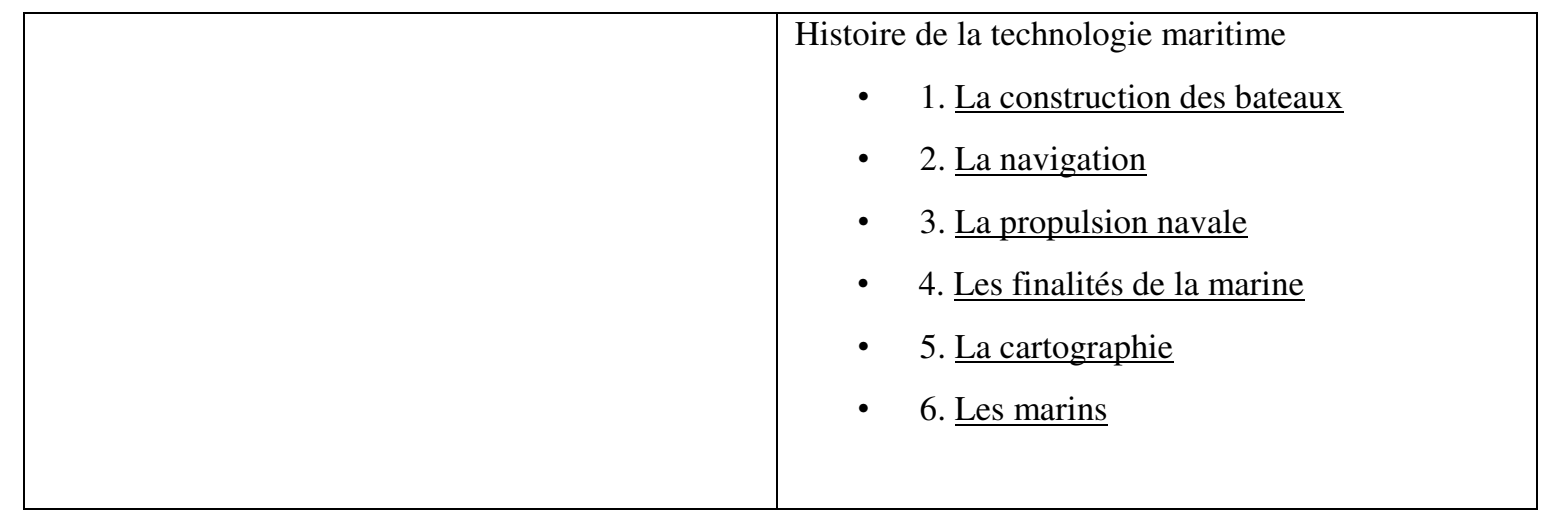

\begin{tabular}{|l|l|}
\hline & La construction des bateaux \\
Caroline Fontes Marques Ferreira \\
Karysa Fernandes dos Santos
\end{tabular}

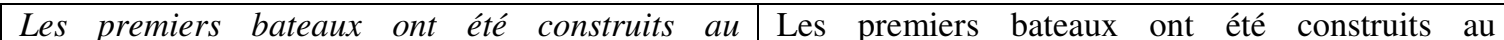
Néolithique, à partir de troncs d'arbre évidés à Néolithique, à partir de troncs d'arbre évidés à l'aide d'outils en pierre, il y a environ 10000 ans. l'aide d'outils en pierre, il y a environ 10000 ans.

Ces premiers bateaux ont une fonction simple, qui est de pouvoir se déplacer sur l'eau, essentiellement Ces premiers bateaux servent essentiellement pour la chasse et la pêche. pour la chasse et la pêche.

Âge du Bronze

Il y a environ 5000 ans, des constructeurs, tant en Égypte que ceux vivant au bord de la rivière Åmose au Danemark commencent à creuser une rangée de trous, le long du bord supérieur de leurs pirogues, puis à l'aide de cordes en tendons ou en fibres végétales, ils «cousent » sur les flancs de la pirogue une planche portant des trous en position concordante. Ils inventent ainsi le bordage cousu, qui permettra progressivement d'augmenter la taille des embarcations. Ce bordage, en surélevant les bords, protège des entrées d'eau, mais permet du même coup d'augmenter significativement la

\section{Âge du Bronze}

Il y a 5000 les hommes «cousent» sur les flancs de la pirogue une planche qui, en surelevant les bords, protège des entrées d'eau et permet d'augmenter la capacité de charge de l'embarcation. 
capacité de charge de l'embarcation.

\begin{tabular}{|l|l|}
\hline Antiquité & Antiquité \\
Les Égyptiens, il y a 5000 ans, ont déjà une parfaite & Les Égyptiens ont contruit, il y a 5000 ans, la \\
maîtrise de la construction des voiliers, dont on a & célèbre barque solaire devant la pyramide de \\
retrouvé un exemplaire remarquable, la célèbre & Gizeh. Outil de culte funéraire elle a été construite \\
barque solaire, devant la pyramide de Gyzeh. La & par copie des techniques maitrisées par les \\
barque, en bois de cèdre, à bordage cousu, mesure & égyptiens. \\
$43,5 \mathrm{~m}$ de long, sa proue s'élève à 5 m et sa poupe à & \\
7 m. Si cette barque est un outil de culte funéraire, & \\
il est évident qu'elle a été construite par simple & \\
copie des techniques alors maîtrisées par les & \\
égyptiens.
\end{tabular}

\begin{tabular}{|l|l}
\hline Moyen Âge & Moyen Âge
\end{tabular}

Jusqu'à la Renaissance, à part quelques exceptions, les bateaux, qu'ils soient à rame ou à voile, vont conserver cette caractéristique polyvalente. Les Vikings, comme en témoigne la tapisserie de Bayeux, utilisent le même navire, un knörr mirameur mi-voilier, pour explorer l'Amérique du Nord, commercer dans la mer Baltique ou envahir la Normandie et remonter la Seine jusqu'aux portes de Paris.

Les Vikings, utilisent le même navire, un knörr mi-rameur mi-voilier, pour explorer l'Amérique du Nord, commercer dans la mer Baltique ou envahir la Normandie et remonter la Seine jusqu'aux portes de Paris.

Até esse ponto as alunas mantiveram-se no texto da Wikipédia, disponível em http://fr.wikipedia.org/wiki/Histoire_des_bateaux , ao encontrar para o item Renaissance um texto pouco suscetível de ser resumido, elas buscam outra fonte: http://desbateaux.free.fr/quinzieme/quinzieme.htm . 


\begin{tabular}{ll|l}
\hline Renaissance & Renaissance \\
La caravelle était un bateau utilisé principalement & La caravelle était un bateau utilisé principalement \\
par le Portugal et l'Espagne. Elle possédait une & par le Portugal et l'Espagne. Elle possédait deux, \\
large étrave et un château arrière haut et étroit. & trois ou quatre mâts portant des voiles latines. C'est \\
Gréée en deux, trois ou quatre mâts portant des & avec ce genre de bateau que Christophe Colomb \\
voiles latines (voiles triangulaires), si elle avait & entreprit ses expéditions vers le continent \\
plus de deux mâts, le mât de misaine (à l'avant) & américain. \\
portait une voile carrée. C'est avec ce genre de & \\
bateau que Christophe Colomb entreprit ses &
\end{tabular}

Para o slide seguinte, a mesma estratégia é mantida: aproveita-se o título da Wikipédia, mas sendo o texto pouco propício para um resumo, as alunas buscam outro texto, através de um link do próprio artigo - revolution industrielle http://fr.wikipedia.org/wiki/R\%C3\%A9volution_industrielle . Dentro desse artigo, o trecho selecionado deve ter sido localizado pelo índice, ele encontra-se, entretanto, no meio de um parágrafo, depois de cinco linhas de texto.

Révolution industrielle
La navigation à vapeur commença donc sur les
rivières, dans les ports pour les remorqueurs, et
sur des trajets courts, comme la traversée de la
Manche. Les bateaux à vapeur progressent
rapidement, tant en nombre qu'au niveau
technique.
Révolution industrielle

La navigation à vapeur commença donc sur les rivières, dans les ports pour les remorqueurs, et sur des trajets courts, comme la traversée de la Manche. Les bateaux à vapeur progressent rapidement, tant en nombre qu'au niveau technique.

A recomendação da professora de falar sobre o século XX gerou uma pesquisa nos sites indicados na lista encontrada no Anexo 1: http://www.navistory.com/ . Esse endereço 
apresenta um item $\underline{\text { 20e siècle. }}$ Dentro desse assunto, foram retidos três itens: os navios de passageiros, a marinha de guerra e os cargueiros.

\begin{tabular}{|l|l|}
\hline XXe. siècle (...) & XXo. siècle \\
Les paquebots deviennent les stars de la mer, & Les paquebots deviennet les stars de la mer surtout \\
surtout sur la ligne transatlantique, où de & sur la ligne transatlantique, où de veritables palais \\
véritables palais flottants rivalisent de faste et de & flottants. \\
vitesse, proposant à une clientèle toujours plus & \\
huppée de prestations que l'aviation naissante ne & \\
peut encore lui contester.
\end{tabular}

\begin{tabular}{|c|c|}
\hline 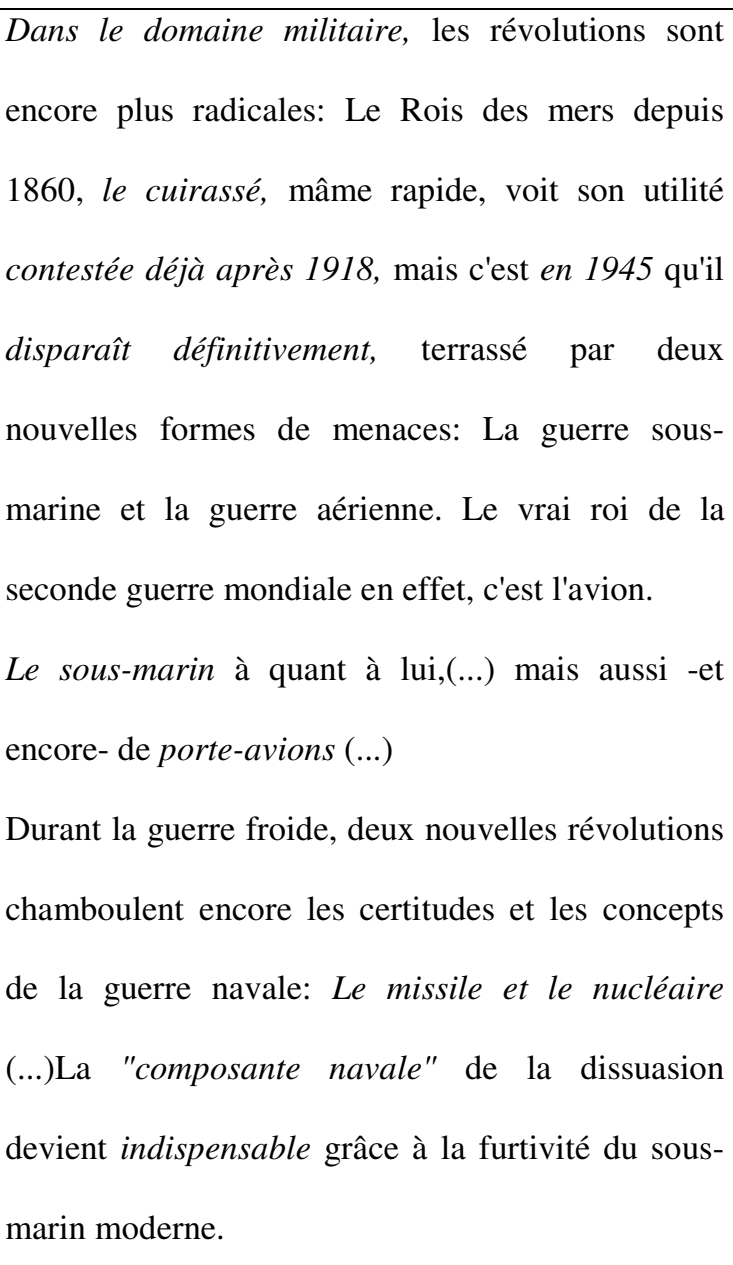 & $\begin{array}{l}\text { XXo. siècle } \\
\text { La marine militaire : } \\
\text { Dans le domaine militaire, le cuirassé, contesté } \\
\text { déjà depuis 1918, disparait définitivamente em } \\
1945 \text {. } \\
\text { La deuxième guerre mondiale est dominé par le } \\
\text { sous-marin et le porte-avions. } \\
\text { Actuellement les missiles et la propulsion nucléaire } \\
\text { rendent la « composante navale » indispensable. }\end{array}$ \\
\hline
\end{tabular}

Après la seconde guerre mondiale, le transport maritime bénéficie de la révolution du système des conteneurs, débouchant sur une nouvelle classe de "cargos" de gros tonnage. Au plus fort des remaniements géopolitiques, on conçoit des
XXo.siècle

« Cargos » :

Le système de conteneurs produit une nouvelle classe de « cargos » de gros tonnage.

On conçoit de «supertankers » de plus de 400 


\begin{tabular}{|c|c|}
\hline $\begin{array}{l}\text { "supertankers" de plus de } 400 \text { mètres de long. } \\
\text { Jamais machine plus grande et plus lourde n'à été } \\
\text { construite de mémoire humaine. }\end{array}$ & $\begin{array}{l}\text { mètres de long. Jamais machine plus grande et plus } \\
\text { lourde n'a été construite de mémoire humaine. }\end{array}$ \\
\hline & $\begin{array}{l}\text { Sites utilizados } \\
\text { www.desbateaux.free.fr } \\
\text { www.sevenroad002.com } \\
\text { Wikipédia } \\
\text { Fin !!! }\end{array}$ \\
\hline
\end{tabular}

\begin{tabular}{|c|c|}
\hline & $\begin{array}{l}\text { La navigation } \\
\text { Rogério Marinho Tavares Conde }\end{array}$ \\
\hline $\begin{array}{l}\text { La navigation est l'habileté et la science de } \\
\text { déterminer la position d'un navire en mer. Les } \\
\text { navigateurs tracent également un parcours jusqu'à } \\
\text { leur prochaine destination. }\end{array}$ & $\begin{array}{l}\text { La navigation est l'habileté et la science de } \\
\text { déterminer la position d'un navire en mer }\end{array}$ \\
\hline
\end{tabular}

Lorsque les navires perdent la terre de vue, les navigateurs doivent compter sur des observations du Soleil et des étoiles effectuées avec des instruments de navigation.

http://www.beyondthemap.ca/french/ship_astrolabe.html
Lorsque les navires perdent la terre de vue, les navigateurs doivent compter sur des observations du Soleil et des étoiles effectuées avec des instruments de navigation.

\section{http://visite.artsetmetiers.free.fr/instruments.html}

L'astrolabe est une représentation plane de la sphère armillaire. Il est construit pour une latitude donnée. Il permet de repérer la position des astres.
Des instruments de navigation

L'astrolabe est une représentation plane de la sphère armillaire. Il est construit pour une latitude donnée. Il permet de repérer la position des astres.

http://fr.wikipedia.org/wiki/Boussole

Une boussole est un instrument de navigation constitué d'une aiguille magnétisée qui s'aligne sur le champ magnétique de la Terre.
Une boussole est un instrument de navigation constitué d'une aiguille magnétisée qui s'aligne sur le champ magnétique de la Terre.

\section{http://visite.artsetmetiers.free.fr/instruments.html}

\begin{tabular}{|l|}
\hline Le sextant \\
Instrument est utilisé pour déterminer la position \\
géographique de l'observateur. Il était \\
particulièrement utilisé pour la navigation.
\end{tabular}

\section{Le sextant}

Instrument est utilisé pour déterminer la position géographique de l'observateur. Il était particulièrement utilisé pour la navigation.

\section{L'octant}

Cet appareil de mesure est de la même famille que le sextant. Son nom vient de sa taille : le secteur angulaire est de $45^{\circ}$ soit un huitième de cercle.

\section{L'octant}

Cet appareil de mesure est de la même famille que le sextant. Son nom vient de sa taille : le secteur angulaire est de $45^{\circ}$ soit un huitième de cercle.

\section{http://www.linternaute.com/dictionnaire/fr/definition/gyroscope/}

gyroscope, nom masculin

Sens Appareil indiquant une direction constante
Gyroscope

Appareil indiquant une direction constante grâce à 


\section{http://www.linternaute.com/dictionnaire/fr/definition/sonar/} http://fr.wikipedia.org/wiki/Sonar

sonar, nom masculin
Sens Appareil de détection sous-marine [Marine].
Un sonar (acronyme de sound navigation and
ranging) est un appareil, utilisant les propriétés
particulières de la propagation du son dans l'eau
pour détecter et situer les objets sous l'eau.

\section{Sonar}

Appareil de détection

sous-marine utilisant les propriétés particulières de la propagation du son dans l'eau pour détecter et situer les objets sous l'eau.

\section{www.linternaute.com/dictionnaire/fr/definition/radar/}

\section{radar, nom masculin}

Sens Dispositif qui permet de déterminer la distance et la direction d'un obstacle par réflexion d'ondes électromagnétiques [Technique].

\section{Radar}

Dispositif qui permet de déterminer la distance et la direction d'un obstacle par réflexion d'ondes électromagnétiques

\section{http://fr.wikipedia.org/wiki/NAVSTAR_GPS}

Le Global Positioning System plus connu par son sigle GPS, que l'on peut traduire en français par " système de positionnement mondial » ou encore (en respectant le sigle) Géo-Positionnement par Satellite, est le principal système de positionnement par satellite mondial actuel;

\section{GPS}

Le GPS, que l'on peut traduire en français par «système de positionnement mondial » ou encore Géo-Positionnement par Satellite, est le principal système de positionnement par satellite mondial actuel.

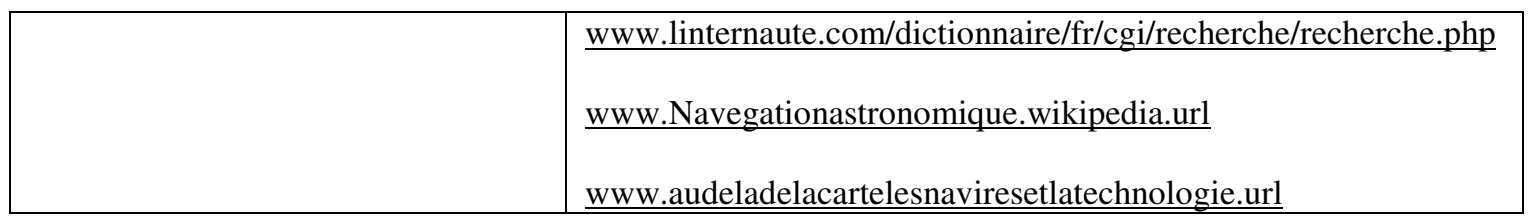

http://fr.wikipedia.org/wiki/Propulsion_maritime

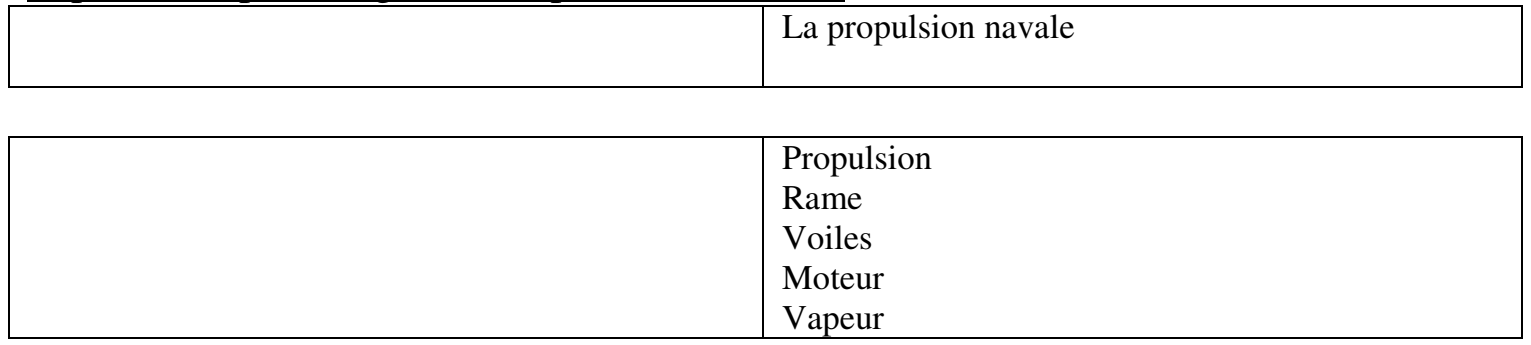

La rame

De manière générale, ce type de propulsion consiste à actionner une rame formée d'un manche et d'une pelle immergée. (...)
La rame

Ce type de propulsion consiste à actionner une rame formée d'un manche et d'une pelle immergée.
L'action effectuée consiste en un va-et-vient régulier, (...)
La rame

L'action effectuée consiste en un va-et-vient régulier.
La propulsion vélique consiste à utiliser la force du vent (le moteur) (...)
La voile

La propulsion vélique consiste à utiliser la force du vent (le moteur)... 
pour propulser un voilier, le plus souvent grâce à des voiles (le propulseur).
La voile

...pour propulser un voilier, grâce à des voiles (le propulseur).

\section{Le moteur}

Le moteur est chargé de transformer l'énergie primaire du combustible en énergie mécanique et / ou électrique, parfois hydraulique. Les deux principales catégories sont les moteurs à combustion externe (chaudières et machines ou turbines à vapeur)

\section{Le moteur}

Les deux principales catégories sont les moteurs à combustion externe (chaudières et machines ou turbines à vapeur). et ceux à combustion interne (moteurs Diesel, moteurs à essence et turbines à gaz).

Combustion externe : la vapeur

Ce système est le plus ancien. Il se caractérise par sa division en deux parties : la chaudière produit de l'énergie en chauffant de l'eau en vapeur grâce au combustible; à combustion interne (moteurs diesel, moteurs à essence et turbines à gaz)

\section{Vapeur}

Ce système se caractérise par sa division en deux parties :

la chaudière produit de l'énergie en chauffant de l'eau en vapeur grâce au combustible ; le moteur transforme cette énergie calorique en travail mécanique.

Texto não encontrado. le moteur transforme cette énergie calorique en travail mécanique.

\begin{tabular}{|l|l|}
\hline & $\begin{array}{l}\text { Le moteur à vapeur emploie deux systèmes de } \\
\text { propulsion: } \\
\text { La roue à aubes } \\
\text { L'hélice }\end{array}$ \\
\hline
\end{tabular}

\section{http://fr.wikipedia.org/wiki/Roue_\%C3\%A0_aubes}

\section{Roue à aubes (...)}

La faiblesse du rendement, l'encombrement et la prise au vent, alliés à une fragilité importante (surtout pour les navires militaires) les fit abandonner au profit des hélices sauf dans des cas particuliers de faible tirant d'eau (bateaux sur le Mississippi, par exemple).
La roue à aubes

Utilisée dans cas de faible tirant d'eau (bateaux sur le Mississippi, par exemple).

http://fr.wikipedia.org/wiki/H\%C3\%A9lice

L'hélice est devenue depuis le moyen de propulsion

le plus courant pour déplacer un bateau ou un sous-marin.

\section{L'hélice}

L'hélice est le moyen de propulsion le plus courant pour déplacer un bateau ou un sous-marin

http://fr.wikipedia.org/wiki/Propulsion_maritime

Propulsion motorisée

La propulsion motorisée consiste à actionner un propulseur grâce à un moteur.

\section{Moteur à Explosion}

La propulsion motorisée consiste à actionner un propulseur grâce à un moteur.

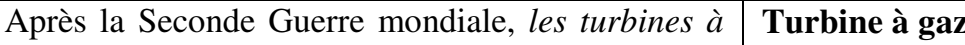

gaz dérivées des réacteurs d'avion s'ajoutèrent à la Les turbines à gaz sont dérivées des réacteurs 


\begin{tabular}{|c|c|}
\hline liste. & d'avion \\
\hline $\begin{array}{l}\text { Il s'agit en général de turbines aéronautiques } \\
\text { "marinisées" (ajout d'une arbre et matériaux } \\
\text { résistants à la corrosion). }\end{array}$ & "marinisées" (matériaux résistants à la corrosion) \\
\hline & 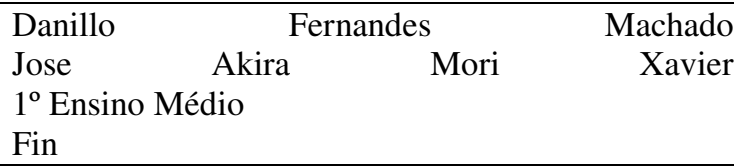 \\
\hline
\end{tabular}

\section{http://fr.wikipedia.org/wiki/Bateau}

- 6 Utilisations et classification
- 6.1 Navires de commerce
○ 6.2 Bâtiments militaires
- $\underline{6.3}$ Bateaux de pêche
- 6.4 Bateaux de loisir
- 6.5 Bateaux de compétition
$\circ \quad \underline{6.6}$ Bateaux fluviaux

Las finalités de la marine

Jéssica Perassi e Stella Gubitoso
Les navires de commerce comprennent trois grandes catégories: les cargos, les navires à passagers, et les navires de service et spécialisés.

Les navires à passagers transportent des personnes (...)

Les navires cargo servent au transport de marchandises sèches ou liquides. (...)
Navires de commerce

* Les navires a passagers destinés au transport de personnes ;

* Les navires cargo destinés au transport de marchandises ;

* Les navires de services et navires spécialisés.
Leur coque est en acier, voire en aluminium pour les plus rapides ; seuls les petits bateaux de service sont en plastique. (...)

Ils sont propulsés typiquement par une hélice unique entraînée par un moteur Diesel; les bateaux à grande vitesse emploient des hydrojets et parfois une turbine à gaz.
Leur coque est en acier, ou en aluminium; les petits bateaux de service sont en plastique.

Ils sont propulsés par une hélice unique entraînée par un moteur Diesel ; les bateaux à grande vitesse emploient des hydrojets et parfois une turbine à gaz.

\section{Bâtiments militaires}

Les navires de guerre modernes sont divisés en différents types correspondant à leur armement, leur taille et leur mission. (...)

\section{Bâtiments militaires}

Ces bateaux ont généralement des formes fines et des machineries dédiées à la vitesse et à la manœuvrabilité. Ils incluent de nombreux systèmes électroniques, de communication et d'armement logés dans un espace confiné.

\section{Bâtiments militaires}

Les navires de guerre modernes sont divisés en différents types correspondant à leur armement, leur taille et leur mission.

\section{Bâtiments militaires}

Ces bateaux ont généralement des formes fines et des machineries dédiées à la vitesse et à la manœuvrabilité. 
Les bateaux de pêche peuvent être assimilés à des navires commerciaux, mais leur dimensions réduites et leur utilisation souvent « artisanale » les font souvent classer à part. Ils sont classés selon plusieurs critères : selon le type de poisson qu'ils pêchent (ainsi les thoniers, sardiniers, crevettiers...) ; selon la méthode de pêche utilisée (d'où les chalutiers, les fileyeurs, les bolincheurs...) ; ou selon leur origine géographique ou caractéristiques techniques tels que le gréement : sinagos, lanches, bisquines...

Ces bateaux sont souvent petits (une centaine de mètres pour les grands thoniers ou baleiniers, mais souvent guère plus de 20 à $30 \mathrm{~m}$ ), ventrus et dotés de cales suffisamment grandes pour une bonne autonomie. Le poisson pêché peut être simplement stocké dans de la glace, ou traité directement à bord pour pouvoir être vendu plus rapidement une fois au port ; (...)
Les bateaux de pêche sont classés selon le type de poisson qu'ils pêchent (ainsi les thoniers, sardiniers, crevettiers...); selon la méthode de pêche utilisée ; ou selon leur origine géographique ou caractéristiques techniques ...
Bateaux de loisir

Les bateaux de plaisance regroupent notamment les voiliers et les yachts qui servent aux loisirs; ceux-ci incluent le nautisme à voile ou motorisé, la croisière côtière et hauturière, la promenade) la journée, voire le simple fait de rester au port pour certains grands yachts de luxe !

\section{Bateaux de compétition}

Les bateaux de compétition sont ceux destinés aux régates et autres compétitions sportives telles que les records de vitesse ou de distance. Parmi les voiliers (...)

\section{Bateaux de pêche}

Ces bateaux sont souvent petits (une centaine de mètres pour les grands thoniers ou baleiniers, mais souvent guère plus de 20 à $30 \mathrm{~m}$ ), ventrus et dotés de cales suffisamment grandes pour une bonne autonomie.

\section{Bateaux fluviaux}

La navigation fluviale a de tous temps représenté un moyen privilégié pour le déplacement des hommes et des marchandises, avant même le développement de la navigation maritime. Le symbole de la Louisiane est souvent lié à ces célèbres bateaux à fond plat mus par des roues à aube

\section{Bateaux de loisir}

Les bateaux de plaisance regroupent notamment les voiliers et les yachts qui servent aux loisirs.

O título do trabalho foi tirado de uma exposição relatada em http://expositions.bnf.fr/cartes/

\section{Bateaux de compétition}

Les bateaux de compétition sont ceux destinés aux régates et autres compétitions sportives telles que les records de vitesse ou de distance.

\section{Histoire de la Cartographie O site site citado Histoire de la Cartographie na referência \\ http://fr.wikipedia.org/wiki/Cartographie\#.C3.89tapes_de_la_fabrication_d.27une_carte foi encontrado através de uma pesquisa com os termos "Definition de la Cartographie », por considerarem as alunas que o texto já escolhido anteriormente http://expositions.bnf.fr/cartes/ carecia de uma introdução.}

La cartographie désigne la réalisation et l'étude Definition de la Cartographie: des cartes. Elle mobilise un ensemble de 
techniques servant à la production des cartes. La cartographie constitue un des moyens privilégiés pour l'analyse et la communication en géographie. Elle sert à mieux comprendre l'espace, les territoires et les paysages.
La cartographie désigne la réalisation et l'étude des cartes, un des moyens privilégiés pour l'analyse et la communication en géographie.
À l'époque moderne, les cartes se veulent une reproduction fidèle d'un paysage, d'une portion de l'espace terrestre : tous les éléments constitutifs d'un paysage sont représentés selon des conventions, avec des symboles. Chaque élément est représenté à l'échelle de la réalité ; les éléments trop petits en surface plane sont remplacés par des symboles d'une taille proportionnelle à leur importance relative (noms des villes de plus en plus grands selon leur population ou leur fonction administrative).
Les cartes se veulent une reproduction fidèle d'une portion de l'espace terrestre : chaque élément est représenté à l'échelle de la réalité .

\section{A partir desse ponto, o texto é tomado de http://expositions.bnf.fr/cartes/.}

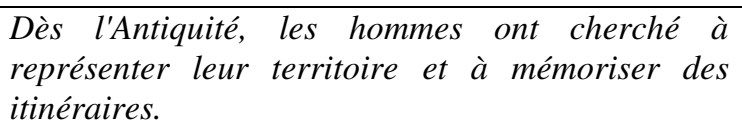

Não compreendendo a palavra conçoit do texto original, as alunas pedem à professora um sinônimo e a substituem.

Les Grecs vont élaborer un système de
représentation du monde et jeter les bases de la
cartographie. Vers 650 avant Jésus-Christ, Thalès
de Millet conçoit déjà la rotondité de la Terre, ce
que confirmera quelques siècles plus tard Aristote
en s'appuyant sur l'image des bateaux
disparaissant progressivement à l'horizon comme
aspirés par la mer.

Dès l'Antiquité, les hommes ont cherché à représenter leur territoire et à mémoriser des itinéraires.

\section{Les Grecs}

Les Grecs élaborent un système de représentation du monde et jettent les bases de la cartographie.

Vers 650 avant J.-C., Thalès de Millet imagine déjà la rotondité de la Terre, ce que confirmera plus tard Aristote en s'appuyant sur la disparition progressive des bateaux à l'horizon.
Tout le savoir grec est résumé au IIe siècle après Jésus-Christ par un astronome et géographe grec, Ptolémée, né à Alexandrie. Dans la vision de Ptolémée, la Terre ronde s'inscrit au centre de l'univers. Un quart seulement du globe est habité, c'est l'acoumène, isolé par un océan infranchissable.
Au Moyen Âge, en Occident, la vision chrétienne prédomine et les mappemondes médiévales mettent en scène une représentation symbolique.

\section{Ptolémée}

$\mathrm{Au}$ IIe siècle après J.-C, un astronome et géographe grec, Ptolémée, croit la Terre ronde et inscrite au centre de l'univers. Un quart seulement du globe est habité, c'est l'œcoumène, isolé par un océan infranchissable.
Les mappemondes arabes privilégient deux types de représentations : l'une de la terre habitée dans la tradition de Ptolémée, l'autre consacrée au monde musulman rassemblé autour de La Mecque.

\section{Moyen Âge}

Au Moyen Âge, en Occident, la vision chrétienne prédomine et les mappemondes médiévales mettent en scène une représentation symbolique

\section{Les arabes}

Les mappemondes arabes représentent la terre habitée dans la tradition de Ptolémée ou mettent en scène le monde musulman rassemblé autour de La Mecque.

Les Arabes reprennent les travaux des Grecs et font revivre la tradition scientifique de la cartographie.

\section{Al-Idrîsî}

Au XIIe siècle le géographe arabe al-Idrîsî établit 
Au XIIe siècle le géographe arabe al-Idrîsî établit une carte du monde et rassemble l'essentiel du savoir géographique de son temps. une carte du monde et rassemble l'essentiel du savoir géographique de son temps.
A la fin du XVe et au début du XVIe siècle, les grands navigateurs espagnols et portugais élargissent considérablement les connaissances géographiques. L'Amérique apparaît pour la première fois sur la carte du monde.

\section{L'Amérique}

A la fin du XVe et au début du XVIe siècle, les grands navigateurs espagnols et portugais élargissent considérablement les connaissances géographiques. L'Amérique apparaît pour la première fois sur la carte du monde.

Les progrès de l'astronomie et des mathématiques ont une grande influence sur la cartographie. De nouveaux instruments permettent de mesurer les angles, de calculer latitude et longitude, d'apprécier les altitudes avec précision.

\section{Les Progrès de La Cartographie}

Les progrès de l'astronomie et des mathématiques ont une grande influence sur la cartographie. De nouveaux instruments permettent de mesurer les angles, de calculer latitude et longitude, d'apprécier les altitudes avec précision.
De nos jours, la cartographie connaît une véritable révolution. Le développement des capteurs numériques et la multiplication des instruments en orbite offrent la possibilité de décrire les zones terrestres les plus inaccessibles comme l'Antarctique.

\section{Cartographie de Nos Jours}

De nos jours, la cartographie connaît une véritable révolution. Le développement des capteurs numériques et la multiplication des instruments en orbite offrent la possibilité de décrire les zones terrestres les plus inaccessibles comme l'Antarctique.

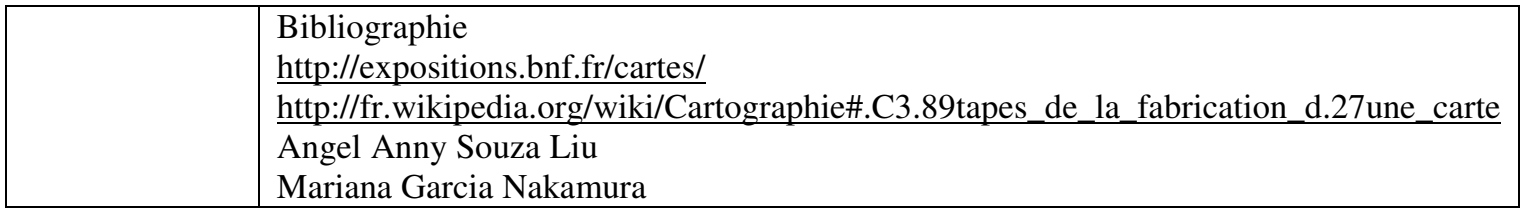

Les Marins

Gabriela Fernandes Parra

Inês de Almeida Zaine

http://desbateaux.free.fr/index.htm

Au fil du temps l'Homme a appris à naviguer, à se déplacer sur l'eau. Cela lui a permis de découvrir d'autres lieus, d'autres mondes. Nous allons essayer de voir l'évolution des techniques au cours des siècles.

A partir desse ponto http://desbateaux.free.fr/audebut/audebut.htm, o site não permitia $o$ recurso de copiar/colar e, portanto, o texto foi redigitado.

Nous pouvons sans trop se (sic) tromper que la première embarcation que l'homme utilisa pour se deplacér fut simplement un tronc d'abre sur lequel il se tenait à cheval. (...) Cette technique (...)Les premieres bateaux furent las embarcations fluviales.

Na página relativa à Antiguidade(http://desbateaux.free.fr/antiquite/antiquite.htm), não havia um trecho curto que falasse dos principais povos marinheiros. Por isso, as alunas anotaram os nomes desses povos (les égyptiens, les phéniciens, les romans) e

\section{Les marins dans l'histoire}

Au fil du temps 1'homme a appris à naviguer, à se déplacer sur l'eau. Cela lui a permis de découvrir d'autres lieus, d'autres mondes.

\section{LA PRÉHISTOIRE}

La première embarcation que l'homme utilisa pour se deplacér fut simplement un tronc d'abre sur lequel il se tenait à cheval.

Les premieres bateaux furent las embarcations fluviales. 
continuaram a pesquisar. O texto abaixo foi resultado de uma pesquisa com as palavraschave Marins de l'Antiquité. Trata-se de um relatório apresentado em 1795 à Convenção Nacional, durante a Revolução Francesa, disponível em http://www.bureaudes-longitudes.fr/textes-references/loi-an3-fondation.htm. O trecho selecionado foi encontrado com o recurso Localizar (nesta página).

Cependant, les plus célèbres marins de l'Antiquité ne furent guère que d'excellents caboteurs, parce que l'audace des entreprises était subordonnée à la mesure peu étendue de leurs connaissances astronomiques : à peine osaient-ils perdre de vue les côtes.

\section{ANTIQUITÉ}

Même les plus célèbres marins de l'Antiquité à peine osaient perdre de vue les côtes. C'étaient: les égyptiens, les phéniciens, les romans.

\section{Au XVème siècle}

Le début $d u$ XVème siècle fut marqué par l'aventure de marins qui se mirent à naviguer fort au large des côtes. Les routes transocéaniques commencèrent leur existence. C'est dans cette période que de grands navigateurs partirent découvrir le monde de par les océans bravant tempêtes et la mort, mais surtout contre les grandes peurs de l'inconnu qu'ils durent se battre.

\section{$\underline{\text { XVème SIÈCLE }}$}

Le début du XVème siècle fut marqué par l'aventure de marins qui se mirent à naviguer fort au large des côtes. C'est dans cette période que de grands navigateurs partirent découvrir le monde de par les océans bravant tempêtes et la mort, mais surtout contre les grandes peurs de l'inconnu qu'ils durent se battre.

Para a biografia de Colombo, as alunas utilizaram a Wikipédia (http://fr.wikipedia.org/wiki/Christophe_Colomb) . Entretanto as palavras marcadas em negrito (Navigateur qui fut) não poderiam ter sido acrescentadas por elas, tendo em vista o seu desconhecimento do passé simple. A solução está provavelmente na menção contida no fim da página: Dernière modification de cette page le 2 mai 2008 à 16:20, levando em conta que a pesquisa terminou necessariamente antes de 26.04.08.

A biografia de Fernão de Magalhães foi tirada so site http://www.renaissanceamboise.com/dossier_renaissance/ses_personnages/Les_navigateurs/magellan.php, indicado pela professora.

Christophe Colomb (né en 1451 à Gênes - mort le 20 mai 1506 à Valladolid, Espagne), est le premier européen de l'histoire moderne à traverser l'océan Atlantique en découvrant une route aller-retour entre le continent américain et l'Europe.

Fernand de Magellan

Magellan pense trouver une route vers l'Asie en contournant les terres découvertes par Christophe Colomb.

\section{Les marins les plus célèbres}

Christophe Colomb

Navigateur qui fut le premier européen de l'histoire moderne à traverser l'océan Atlantique en découvrant une route aller-retour entre le continent américain et l'Europe.

Fernand Magellan

Magellan a trouvé une route vers l'Asie en contournant les terres découvertes par Christophe Colomb.

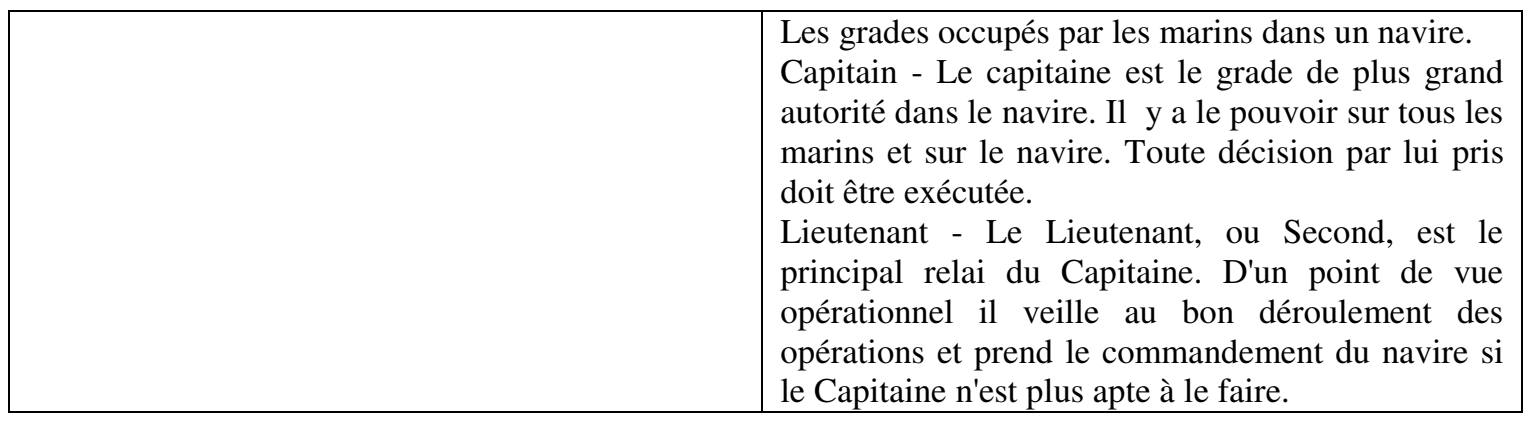




\begin{tabular}{|l|l|}
\hline & $\begin{array}{l}\text { cartes, il s'assure de la bonne position du navire et } \\
\text { calcule les trajectoires au mieux pour limiter le } \\
\text { temps de voyage. } \\
\text { Courantographe -Ce dernier profite de sa science } \\
\text { des courants pour permettre au navire de profiter de } \\
\text { ces derniers et se déplacer plus rapidement lors des } \\
\text { affrontements. } \\
\text { Caliastre -Ce dernier profite de sa science des } \\
\text { étoiles pour permettre une navigation exacte de } \\
\text { nuit. }\end{array}$ \\
\hline
\end{tabular}

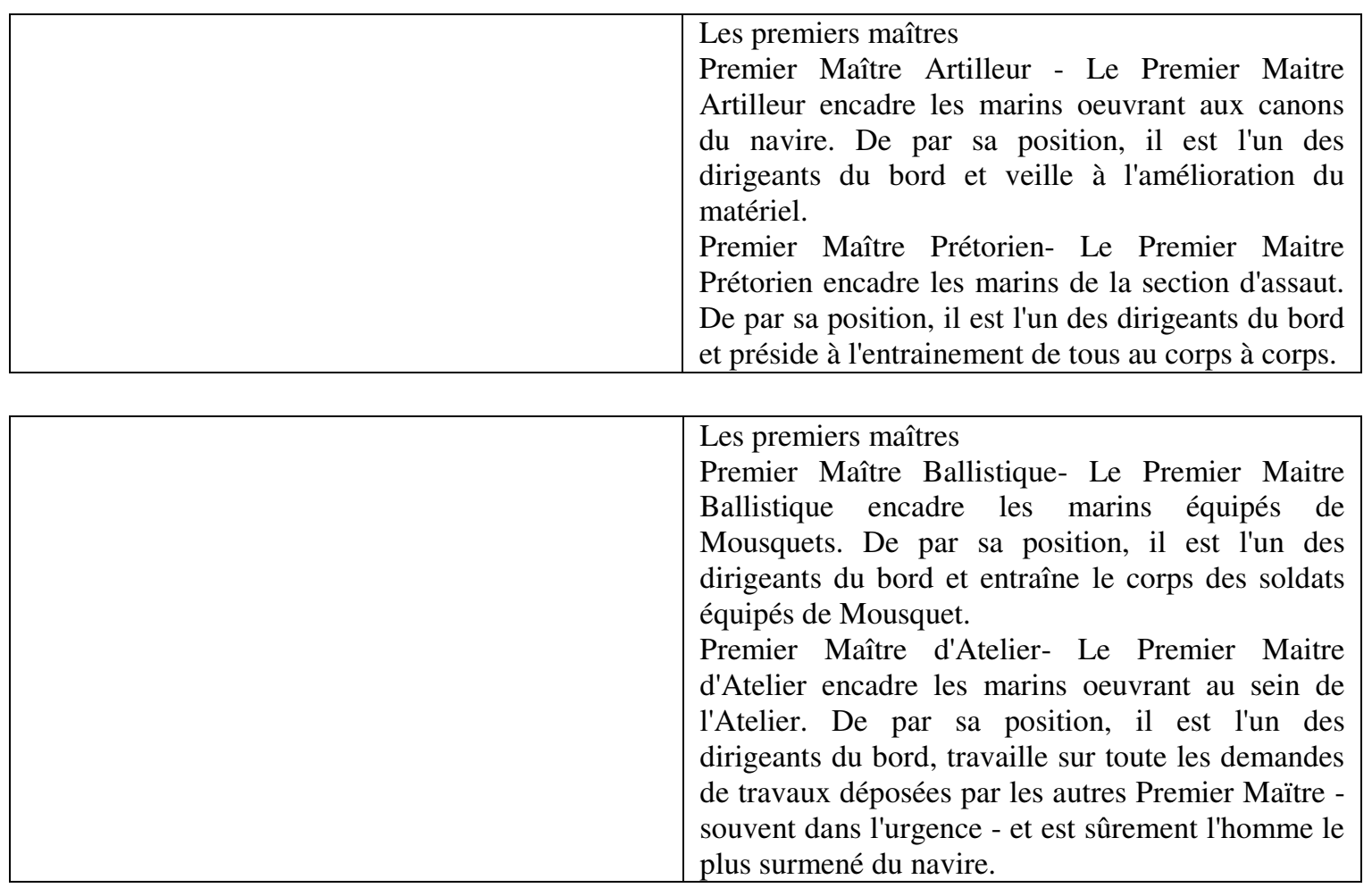

